

$$
\text { DOE/PC/79798-T/18 }
$$

DOE/PC/79798--T18

DCN: 91-209-026-06

DE92 012700

\title{
ENVIRONMENTAL MONITORING FOR THE DOE COOLSIDE AND LIMB DEMONSTRATION EXTENSION PROJECTS
}

\author{
Quaselly \\ FINAE REPORT FOR THE PERIOD OF \\ FEBRUARY, MARCH AND APRIL 1991 \\ DE-FC22-87PC 79798
}

\author{
Prepared For: \\ Paul Nolan \\ Project Manager \\ Babcock and Wilcox \\ 20 S. Van Buren Avenue \\ Post Office Box 351 \\ Barberton, Ohio 44203 \\ Prepared by: \\ Ted White \\ Luke Contos \\ Lucy Adams \\ Radian Corporation \\ Progress Center \\ 3200 East Chapel Hill Road/Nelson Highway \\ Post Office Box 13000 \\ Research Triangle Park, NC 27709
}

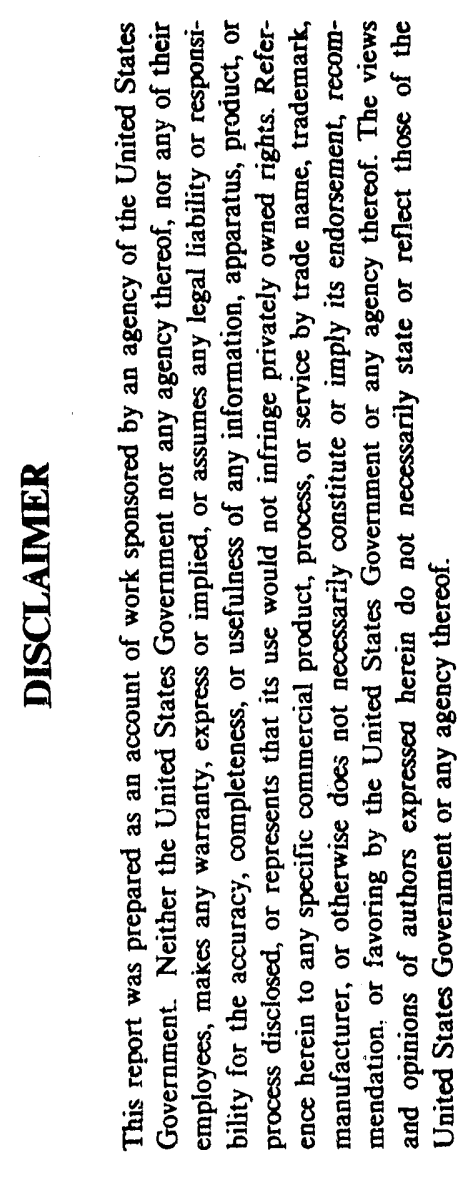

February 1992

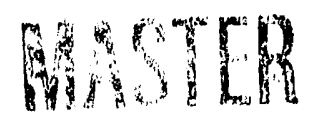




\section{TABLE OF CONTENTS}

$\underline{\text { Section }} \quad \underline{\text { Page }}$

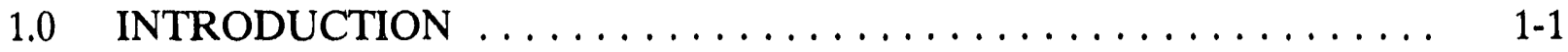

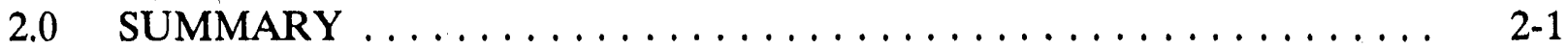

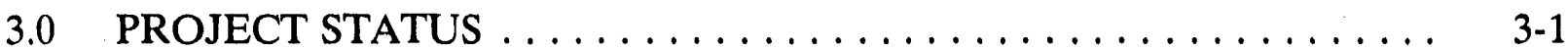

3.1 Overview $\ldots \ldots \ldots \ldots \ldots \ldots \ldots \ldots \ldots \ldots \ldots \ldots \ldots \ldots \ldots \ldots, 1$

3.2 Edgewater Facility Description $\ldots \ldots \ldots \ldots \ldots \ldots \ldots \ldots \ldots, 3-1$

3.3 The LIMB Process $\ldots \ldots \ldots \ldots \ldots \ldots \ldots \ldots \ldots \ldots, 3-2$

3.4 Project Design and Background $\ldots \ldots \ldots \ldots \ldots \ldots \ldots \ldots, 3-4$

3.5 Project Status . . . . . . . . . . . . . . . . . . . . . .

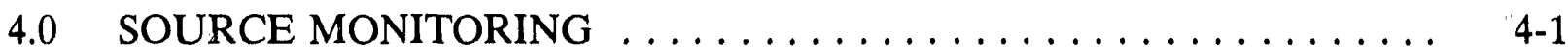

4.1 Gaseous Emissions Monitoring $\ldots \ldots \ldots \ldots \ldots \ldots \ldots \ldots$ 4-1

4.2 Wastewater Monitoring . . . . . . . . . . . . . . . . . . $4-5$

4.3 Solid Waste Discharges . . . . . . . . . . . . . . . . . . 4-11

4.4 Pollution Control Limit Monitoring . . . . . . . . . . . . . . 4-19

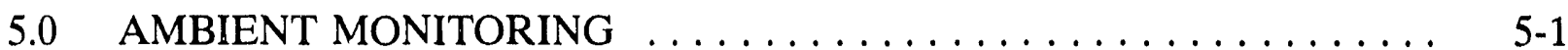

5.1 Ambient Air Dispersion Modeling $\ldots \ldots \ldots \ldots \ldots \ldots \ldots$ 5-1

5.1:1 Air Quality Source Parameters . . . . . . . . . . . . . 5-3

5.1.2 Air Quality Modeling Procedure . . . . . . . . . . . . . 5-5

5.1.3 Air Quality Modeling Results . . . . . . . . . . . . . 5-7

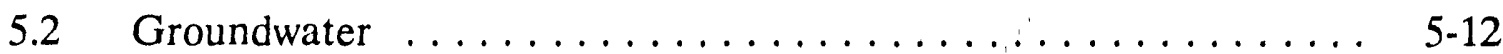

5.3 References $\ldots \ldots \ldots \ldots \ldots \ldots \ldots \ldots \ldots \ldots \ldots \ldots \ldots \ldots \ldots \ldots, 12$

6.0 HEALTH AND SAFETY $\ldots \ldots \ldots \ldots \ldots \ldots \ldots \ldots \ldots \ldots \ldots, 6 . \ldots \ldots$

7.0 COMPLIANCE MONITORING STATUS $\ldots \ldots \ldots \ldots \ldots \ldots \ldots, 7-1$

8.0 QUALITY ASSURANCE/QUALITY CONTROL RESULTS $\ldots \ldots \ldots 8$.

9.0 MONITORING PROBLEMS AND RECOMMENDATIONS

FOR CHANGE $\ldots \ldots \ldots \ldots \ldots \ldots \ldots \ldots \ldots \ldots \ldots \ldots . \ldots \ldots$ 


\section{TABLE OF CONTENTS (CONTINUED)}

$\underline{\text { Section }}$

Page

APPENDIX A - Detailed Daily Average Air Emissions $\ldots \ldots \ldots \ldots \ldots$ A-1

APPENDIX B - 601 Outfall Compliance Reports ................ B-1

APPENDIX C - 601 Outfall Daily $\mathrm{pH}$ and Sample Log $\ldots \ldots \ldots \ldots \ldots$ C-1

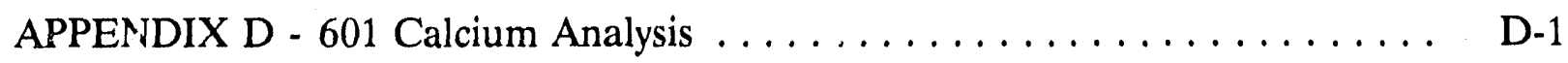

APPENDIX E - TCLP and ASTM DI Leachate Procedures $\ldots \ldots \ldots \ldots$ E-1

APPENDIX F - Analytical Data Summary $\ldots \ldots \ldots \ldots \ldots \ldots \ldots \ldots$ F-1

APPENDIX G - Permeability Data Summary $\ldots \ldots \ldots \ldots \ldots \ldots \ldots$ G-1

APPENDIX H - Ambient Air Modeling Protocol $\ldots \ldots \ldots \ldots \ldots \ldots \ldots, \mathrm{H}-1$

APPENDIX I - Hourly Surface Observations and Mixing Height Data $\ldots . . \quad$ I-1 


\section{LIST OF TABLES}

Table

Page

2-1 COMPARISON OF NPDES OUTFALL 601 MONITORING

DATA DURING BASELINE AND EXTENSION PERIODS

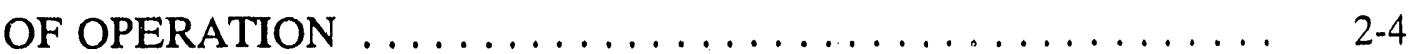

2-2 COMPARISON OF ASH LEACHATE COMPOSITION DATA DURING

EASELINE AND EXTENSION PERIODS OF OPERATION $\ldots \ldots, 2-5$

4-1 SUMMARY OF AVERAGE AIR EMISSIONS DATA $\ldots \ldots \ldots \ldots .4-2$

4-2 NPDES OUTFALL 601 MONITORING DATA - FEBRUARY,

MARCH, AND APRIL $1991 \ldots \ldots \ldots \ldots \ldots \ldots \ldots \ldots \ldots$. $4-8$

4-3 SUMMARY OF NPDES OUTFALL 601 MONITORING

DATA DURING BASELINE AND EXTENSION PERIODS

OF OPERATIONS ........................ $4-9$

4-4 OUTFALL $601 \mathrm{pH}$ AND Ca CONTENT $\ldots \ldots \ldots \ldots \ldots \ldots \ldots \ldots .4 .10$

4-5 ESP ASH CORROSIVITY AND PERMEABILITY RESULTS $\ldots \ldots$. $4-15$

4-6 ANALYSES PERFORMED ON FLY ASH LEACCHATES FROM THE BASELINE AND EXTENSION PERIODS OF OPERATION $\ldots \ldots, 4-17$

4-7 LIMB OPERATION LOG FOR JANUARY, FEBRUARY, MARCH

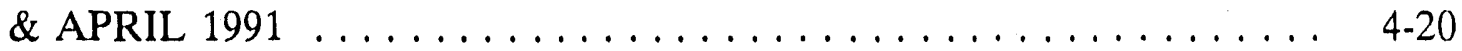

5-1 INJECTION PERIODS MODELED FOR THE CURRENT

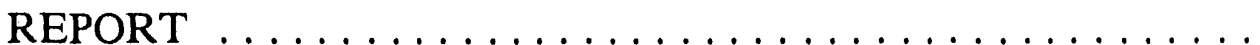

5-2 WORST-CASE OPERATING SCENARIOS DETT :MINED BY

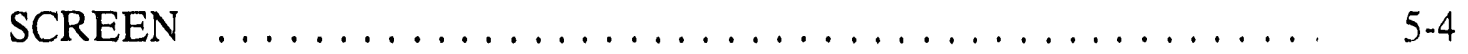

5-3 SCENARIO IMPACTS MINUS BASELINE RESULTS $\ldots \ldots \ldots \ldots . . .5$

5-4 AMBIENT AIR QUALITY MONITORING DATA . . . . . . . . . . . 5-10

5-5 TOTAL SCENARIO $\mathrm{SO}_{2}$ IMPACTS $\ldots \ldots \ldots \ldots \ldots \ldots \ldots \ldots .11$ 


\section{LIST OF TABLES}

Table

Page

5-6 SCENARIO IMPACTS MINUS BASELINE RESULTS FOR THE REFINED MODELING ANALYSIS $\ldots \ldots \ldots \ldots \ldots \ldots \ldots, 5-12$

7-1 SUMMARY OF CURRENTLY REQUIRED AIR COMPLIANCE MONITORING $\ldots \ldots \ldots \ldots \ldots \ldots \ldots \ldots \ldots \ldots, 7.2$ 


\section{LIST OF FIGURES}

Figure $\quad$ Page

3-1 Edgewater Plant Site Layout $\ldots \ldots \ldots \ldots \ldots \ldots \ldots \ldots \ldots \ldots \ldots \ldots \ldots$

3-2 LIMB Injection and Coolside Injection Locations and Flue Gas Sampling Locations for the DOE LIMB Extension Project $\ldots \ldots \ldots \ldots \ldots \ldots \ldots \ldots \ldots \ldots$

4-1 Flow Diagram of Edgewater Plant Water Flows and Outfalls ....................... $4-5$

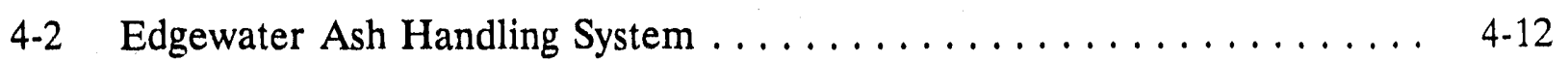

$5-1 \quad$ Modeled Impact Locations $\ldots \ldots \ldots \ldots \ldots \ldots \ldots \ldots \ldots \ldots \ldots \ldots \ldots$ 


\subsection{INTRODUCTION}

The purpose of this document is to present environmental monitoring data collected during the U.S. Department of Energy Limestone Injection Multistage Burner (DOE LIMB) Demonstration Project Extension at the Ohio Edison Edgewater Generating Station in Lorain, Ohio. These data were collected by implementing the Environmental Monitoring Plan (EMP) for the DOE LIMB Demonstration Project Extension, dated August 1988. This document is the sixth EMP status report to be published and presents the data generated during February, March and April 1991. These reports review a three to four month period and have been published since the project's start in October 1989.

The DOE project is an extension of the U. S. Envirorimental Protection Agency's (EPA) original LIMB Demonstration. The program is operated under DOE's Clean Coal Technology Program of "emerging clean coal technologies" under the categories of "in boiler control of oxides of sulfur and nitrogen" as well as "post-combustion clean-up." The objective of the LIMB program is to demonstrate the sulfur dioxide $\left(\mathrm{SO}_{2}\right)$ and nitrogen oxide $\left(\mathrm{NO}_{\mathrm{x}}\right)$ emission reduction capabilities of the LIMB system. The LIMB system is a retrofit technology to be used for existing coal-fired boilers equipped with electrostatic precipitators (ESPs).

As required in the Cooperative Agreement between DOE and Babcock and Wilcox (B\&W), an Environmental Information Volume (EIV), an Environmental Monitoring Plan Outline (EMPO), and an Environmental Monitoring Plan (EMP) were prepared prior to the onset of the DOE project. The EIV was dated May 20, 1987, the EMPO was dated December 23, 1987, and the final EMP was dated August 11, 1988.

This report is organized as follows: Section 1.0 is the Introduction; Section 2.0 presents a Summary of the project for the stated reporting period; Section 3.0 discusses the LIMB Process and the Project Status; Section 4.0 presents Source Monitoring 
Information; Section 5.0 presents Ambient Monitoring Information; Section 6.0 presents the Health and Safety related information; Section 7.0 discusses the Compliance Monitoring Status; Section 8.0 discusses Quality Assurance/Quality Control Results; and Section 9.0 presents Monitoring Problems and Recommendations for Change. Support material related to air emissions, solid waste disposal, and wastewater discharges is presented in the appendices. 


\subsection{SUMMARY}

This section presents a summary of EMP related items which occurred during the February, March and April 1991 reporting period.

The LIMB system was operated this reporting period to evaluate the flue gas desulfurization efficiency of two calcium-based scrbents (dolomitic lime and lignosulfonated lime) during the combustion of two different sulfur content coals (nominal 1.6 and nominal 3.8 percent sulfur by weight). Three sorbent/coal combinations were evaluated during the following three injection periods:

- dolomitic lime/nominal 3.8 percent sulfur coal, 02/04 - 02/20/91;

- lignosulfonated lime/nominal 1.6 percent sulfur coal, 02/21 - 04/05/91; and

- lignosulfonated lime/nominal 3.8 percent sulfur coal, 04/06 - 04/30/91.

The monitoring data and air quality modeling data presented in this report are $r$ ased on emission data that are specific to the coal/sorbent combination utilized during a specific injection period and the combination of combustion and air pollution control equipment used at the Lorain facility. To determine LIMB operating efficiencies and environmental impacts, monitoring and modeling data collected during the sorbent/coal injection periods were compared to Baseline data. Baseline was the period from February 17 to April 22, 1990, where nominal 1.6 percent sulfur coal or "compliance coal" was fired and no LIMB Extension equipment was in operation.

The Baseline data were collected after circular burners had been replaced with low $\mathrm{NO}_{\mathrm{x}}$ burners. An indication of $\mathrm{NO}_{x}$ emissions prior to the demonstration can be found in the paper entitled "Operation of the LIMB/Humidifier Demonstration at Edgewater," presented at the First Combined FGD and Dry $\mathrm{SO}_{2}$ Control Symposium, October 25, 1988, St. Louis, MO. Some of the data presented in that paper were collected when the circular burners were still in operation. 
Since the goal of the LIMB Demonstration Program is to test a wide range of operating conditions, the $\mathrm{SO}_{2}$ and $\mathrm{NO}_{\mathrm{x}}$ emissions averages should not be taken as representative of long-term, optimized operations. Ranges of $\mathrm{SO}_{2}$ and $\mathrm{NO}_{x}$ clata were compiled during periods of formal testing and may include both injection and non-injection periods within a given day.

During this reporting period, the average $\mathrm{SO}_{2}$ mass emission rate was highest during the dolomitic lime/nominal 3.8 percent sulfur coal and the lignosulfonated lime/nominal 3.8 percent sulfur coal injection periods, and was lowest during the lignosulfonated lime/nominal 1.6 percent sulfur coal injection period. The $\mathrm{SO}_{2}$ mass emission rate during this reporting period varied from 880 to $3,400 \mathrm{lb} / \mathrm{hr}$. The average $\mathrm{SO}_{2}$ mass emission rate for each injection period, which ranged from 1,500 to 2,200 $\mathrm{lb} / \mathrm{hr}$, was higher than average $\mathrm{SO}_{2}$ mass emission rate during the Baseline period of 932 $\mathrm{lb} / \mathrm{hr}$. The median $\mathrm{SO}_{2}$ removal efficiency was the highest during the lignosulfonated lime/nominal 3.8 percent sulfur coal injection period and the lowest during the dolomitic lime/nominal 3.8 percent sulfur coal and the lignosulfonated lime/nominal 1.6 percent sulfur coal injection periods. $\mathrm{SO}_{2}$ removal efficiencies for the reporting period varied widely, from 9 to 73 percent.

The average $\mathrm{NO}_{x}$ mass emission - ates for the three sorbent/coal combinations ranged from 160 to $430 \mathrm{lb} / \mathrm{hr}$ this reporting period. The average $\mathrm{NO}_{x}$ mass emission rates for each injection period, which ranged from 250 to $260 \mathrm{lb} / \mathrm{hr}$, were greater than the Baseline average $\mathrm{NO}_{\mathrm{x}}$ emissions of $181 \mathrm{lb} / \mathrm{hr}$. However, with the installation of $\mathrm{B} \& \mathrm{~W} X \mathrm{XL}$ low- $\mathrm{NO}_{x}$ burners, $\mathrm{NO}_{x}$ emissions during this reporting period have clecreased when compared with emissions which occurred prior to the EPA LIMB Demonstration. Modeled ambient air impacts from $\mathrm{SO}_{2}$ and $\mathrm{NO}_{x}$ emissions during these three injection periods will be presented in the next report. Additional information on gaseous emission monitoring is presented in Section 4.1. 
The wastewater discharge at Outfall 601 was monitored during this reporting period. All discharge parameters were within National Pollution Discharge Elimination Systern (NPDES) permit requirements. The change in concentration from the Baseline to each sorbent/coal combination for the NPDES discharge parameters is summarized in Table 2-1. No total phosphorus $(\mathrm{P})$ analyses were performed during this reporting period. Additional information on wastewater monitoring is presented in Section 4.2.

Fly ash samples were composited from October 8 to November 27, 1990 and from November 28 to December 20, 1990. The ash compositing periods correspond to the time periods when the primary sorbent coal combinations were dolomitic lime/nominal 3.8 percent sulfur coal and dolomitic lime/nominal 1.6 percent sulfur coal. The resulting samples were submitted for corrosivity and permeability tests, and were leached using the Toxicity Characteristic Leaching Procedure (TCLP) and a deionized water (DI) leaching procedure--American Society for Testing and Materials (ASTM) D3987. These two leaching procedures will allow for the analyses of the targeted parameters listed in the EMP. The results from each of these analyses is summarized in Table 2-2. The corrosivity of the dolomitic lime/nominal 3.8 percent sulfur coal and the dolomitic lime/nominal 1.6 percent sulfur coal samples were below the detection limit. In addition, the fly ash samples from both periods were less permeable than the Baseline period fly ash. The metal concentrations of the TCLP and DI leachates from both fly ash samples were below the TCLP maximum contaminant levels (MCL's) and below the detection limit for silver $(\mathrm{Ag})$, cadmium $(\mathrm{Cd})$, and mercury $(\mathrm{Hg})$. Additional information on solid waste monitoring is presented in Section 4.3.

Air quality modeling was performed in this reporting period using the four sorbent/coal combinations of the previous reporting period. These combinations were dolomitic lime/nominal 1.6 percent sulfur coal, dolomitic lime/nominal 3.0 percent sulfur coal, dolomitic lime/nominal 3.8 percent sulfur coal, and limestone/nominal 1.6 percent sulfur coal. The modeling demonstrated that $\mathrm{SO}_{2}$ and $\mathrm{NO}_{x}$ concentrations increased over Baseline period concentrations. With the exception of three injection periods, changes in 
TABLE 2-1. COMPARISON OF NPDES OUTFALL 601 MONITORING DATA DURING BASELINE AND EXTENSION PERIODS OF OPERATION

\begin{tabular}{|c|c|c|c|}
\hline \multirow[b]{2}{*}{ Parameter (Units) } & \multicolumn{3}{|c|}{ SORBENT/COAL COMBINATION } \\
\hline & $\begin{array}{c}\text { Dolomitic } \\
\text { Lime/Nominal } \\
3.8 \text { Percent } \\
\text { Sulfur Coal }\end{array}$ & $\begin{array}{c}\text { Lignosulfonated } \\
\text { Lime/Nominal } \\
1.6 \text { Percent Sulfur } \\
\text { Coal }\end{array}$ & $\begin{array}{l}\text { Lignosulfonated } \\
\text { Lime/Nominal } \\
3.8 \text { Percent } \\
\text { Sulfur Coal }\end{array}$ \\
\hline Average $/ \mathrm{s}(\mathrm{Ar} / \mathrm{L})$ & - & - & NA \\
\hline Average $\mathrm{Ca}(\mathrm{mg} / \mathrm{L})$ & + & + & + \\
\hline Average TSS $(\mathrm{mg} / \mathrm{L})$ & - & - & - \\
\hline Average O\&G $(\mathrm{mg} / \mathrm{L})$ & + & - & $\mathrm{NA}$ \\
\hline $\operatorname{Max} \mathrm{pH}$ (s.u.) & + & + & + \\
\hline Min pH (s.u.) & + & + & + \\
\hline
\end{tabular}

$+=$ increase from Baseline concentration.

- = decrease from Baseline concentratio.s.

$\mathrm{NA}=$ no analysis during test period. 


\section{TABLE 2-2. COMPARISON OF ASH LEACHATE COMPOSITION DATA DURING BASELINE AND EXTENSION PERIODS OF OPERATION}

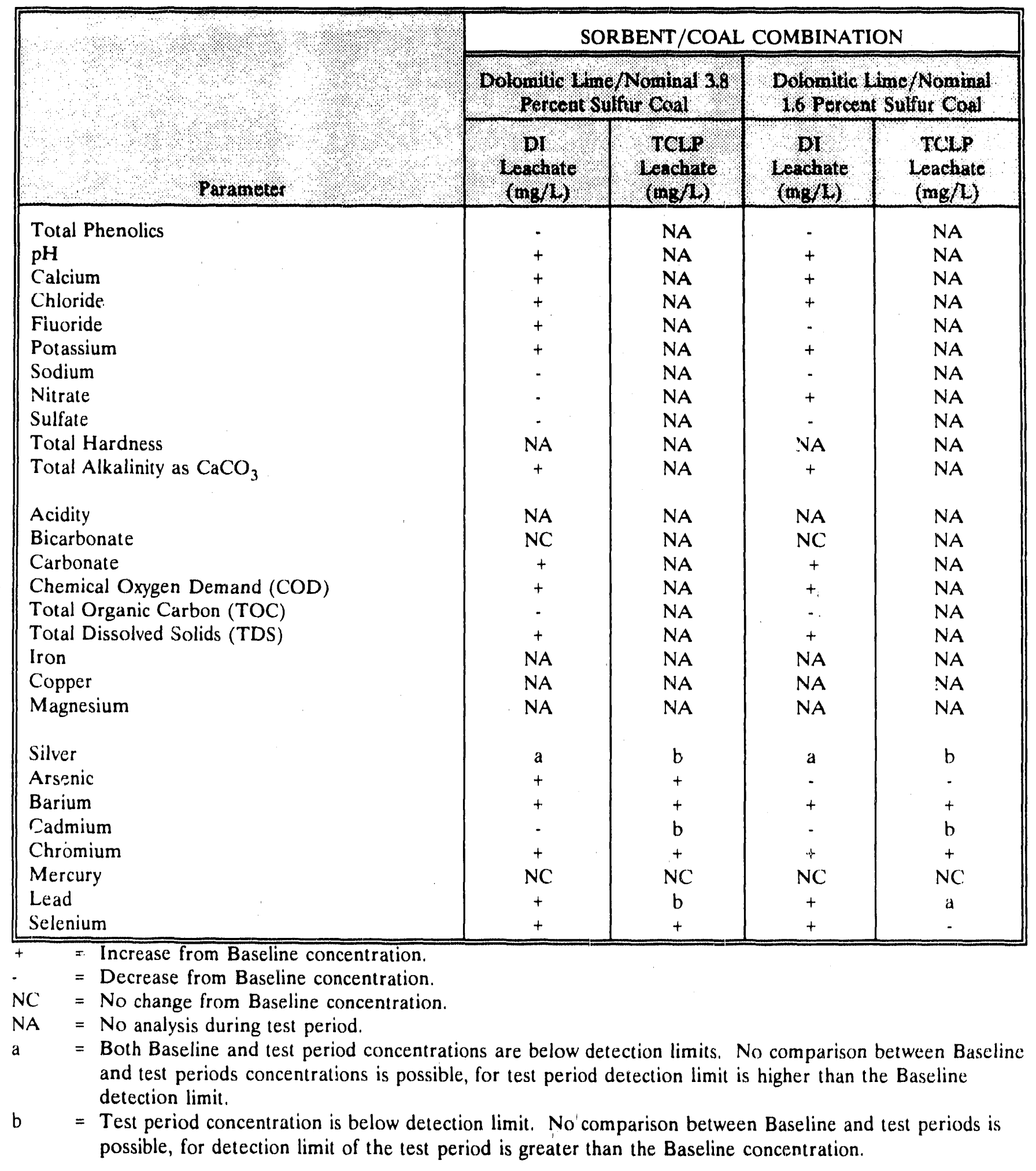


model predicted concentrations were below the ambient air significance levels, as defined in the Prevention of Significant Deterioration (PSD) air regulations (40 CFR 51.165(b)(2)). During the screening or initial modeling, the 3-hour $\left(25 \mu \mathrm{g} / \mathrm{m}^{3}\right), 24$-hour $\left(5 \mu \mathrm{g} / \mathrm{m}^{3}\right)$ and annual $\left(1.0 \mu \mathrm{g} / \mathrm{m}^{3}\right)$ significance levels for $\mathrm{SO}_{2}$ were exceeded during the dolomitic lime/nominal 1.6 percent sulfur coal (11/1 - 11/12/90), dolomitic lime/nominal 3.0 percent sulfur coal, dolomitic lime/nominal 3.8 percent sulfur coal injection periods. Additional modeling, using the Industrial Source Complex Short Term (ISCST) dispersion model, was conducted to determine compliance with the National Ambient Air Quality Standard (NAAQS) for $\mathrm{SO}_{2}$ during the November and December 1990 and January 1991 reporting period. The modeling results demonstrate that the $\mathrm{SO}_{2}$ NAAQS were not exceeded during any of the sorbent/coal injection periods. Additional information on dispersion modeling is presented in Section 5.1. Air dispersion modeling will be conducted in the next reporting period, using emission data from the dolomitic lime and lignosulfonated lime sorbent injection periods in this reporting period.

The employee health and safety monitoring specified in the EMP was completed in the November and December 1990 and January 1991 reporting period. No additional employee health and safety monitoring was conducted during this reporting period.

The facility's compliance monitoring status was reviewed for this period. No air or NPDES permit values, as monitored by Ohio Edison and Radian, were exceeded during this reporting period. Additional information on compliance monitoring is presented in Sections 7.0 and 9.0 . 


\subsection{PROJECT STATUS}

The section presents information on the background of the LIMB project as well as the current project status.

\subsection{Overview}

The DOF LIMB Demonstration Project Extension is a continuation of a LIMB technology demonstration sponsored by the EPA. The purpose of the LIMB system is to reduce $\mathrm{SO}_{2}$ and $\mathrm{NO}_{\mathrm{x}}$ emissions from existing utility power generation plants using cost effective retrofit technologies. Specific goals of the EPA program were to demonstrate 50 to 60 percent reduction of $\mathrm{SO}_{2}$ emissions based on incoming coals containing a nominal 3 percent sulfur. $\mathrm{NO}_{x}$ emissions were expected to be less than $0.5 \mathrm{lb} / \mathrm{million}$ Btu heat input. LIMB has the potential to reduce $\mathrm{SO}_{2}$ emissions at a much lower cost than flue gas desulfurization (FGD) systems, or switching to low-sulfur coals imported from other regions.

\subsection{Edgewater Facility Description}

The LIMB Technology Demonstration is taking place at the Ohio Edison Edgewater Steam Electric Generating Plant located on Lake Erie in Lorain, Ohio. The Edgewater facility has a total net demonstrated power capability of $214 \mathrm{MW}$ and consists of three pulverized coal-fired boilers serving two turbines and two oil-fired combustion turbine generators. The LIMB system was installed in 1986 on Edgewater Unit No. 4, which has a nameplate capacity of $105 \mathrm{MW}$. The boiler associated with Unit No. 4 turbine generator is Boiler No. 13. This unit is a $B \& W$, front wall-fired boiler capable of burning 42.5 tons per hour (tph) of coal. Particulate emissions from Unit No. 4 are controlled with a Lodge-Cottrell ESP, which was retrofitted to the system in 1982. 
Prior to the LIMB Demonstration, the Edgewater facility burned eastern bituminous coal (nominal 1.6 percent sulfur). Total station coal consumption is approximately $70 \mathrm{tph}$ with all units in operation. The coal is delivered by truck. The facility utilizes 110 million gallons per day (MGD) of once-through cooling water taken from Lake Erie, and discharges 1.1 MGD of wastewater to the lake from the fly ash settling ponds. During LIMB Extension activities, fly ash from Unit No. 4 is trucked to a municipal landfill located in the Dover Township. Figure 3-1 presents a simplified schematic of the Edgewater facility layout.

Additional information on the Edgewater facility can be found in the EIV and previously prepared reports for this project.

\subsection{The LIMB Process}

The LIMB process utilizes low- $\mathrm{NO}_{x}$ burners to control the formation of $\mathrm{NO}_{x}$ emissions. To accomplish this reduction, Unit No. 4's original circular register burners were replaced with $\mathrm{B} \& \mathrm{~W} \mathrm{XCL}$ low- $\mathrm{NO}_{\mathrm{x}}$ burners. The burner replacement was completed in 1986 during the EPA Demonstration, and these burne's remain in use.

Sorbent is injected into the combustion gas stream to provide sites for $\mathrm{SO}_{2}$ sorption with downstream particulate collection by the ESP. Two injection systems are currently in place at the Edgewater facility. The first system injects sorbent directly into the boiler. EPA LIMB Demonstration tests were completed using this configuration, with a flue gas humidifying chamber installed in a bypass duct downstream of the boiler. The objective was to increase particulate removal efficiency of the ESP. By decreasing the flue gas temperature, the residence time of the flue gas in the ESP was increased, thereby allowing more time for particulate removal. Also, the resistivity of the fly ash was decreased, which allowed for greater particle-ESP plate attraction and hence, removal. The humidifying chamber was constructed in a bypass duct so that it could be isolated during system upsets and not reduce the generation capability of the unit. 

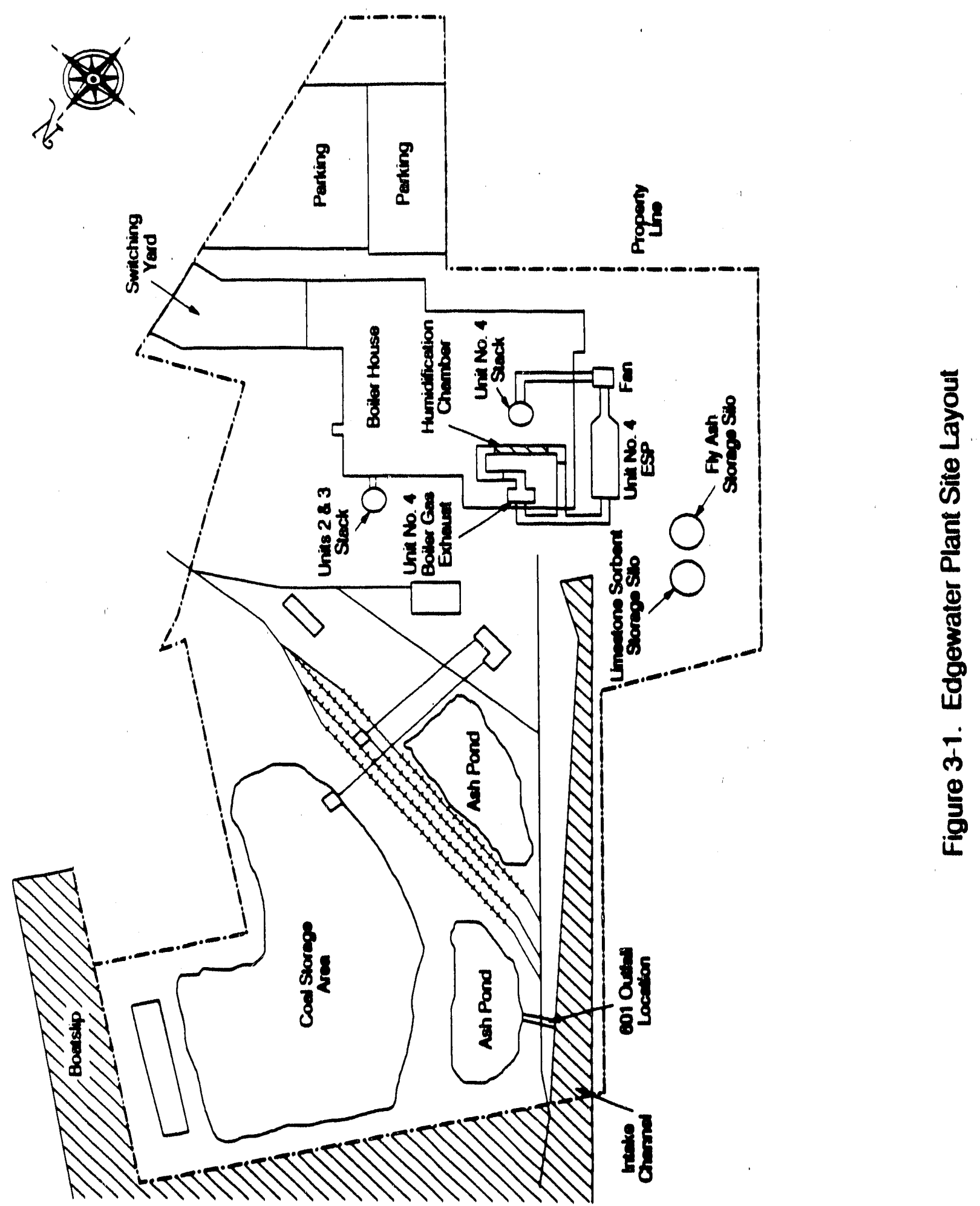

if 
The DOE LIMB Demonstration Project Extension adds a sorbent injection point located upstream of the flue gas humidification to the original boiler. The Demonstration system, known as the "Coolside" process, involved sorbent injection upstream of the humidification chamber and was used in the initial stages of the LIMB Extension project. In addition to solid sorbent injection, a sodium hydroxide solution was added to the humidifying water to enhance $\mathrm{SO}_{2}$ removal. Figure 3-2 presents a generalized schematic of the current sorbent injection configurations present at the Edgewater Facility.

In order to accurately document and analyze $\mathrm{SO}_{2}$ and $\mathrm{NO}_{x}$ reduction efficiencies, as well as boiler operational efficiencies, a variety of parameters are monitored. Boiler operation measurements such as fluid temperatures, pressures, and flow rates are continuously monitored, as are stack gas concentrations of $\mathrm{SO}_{2}, \mathrm{NO}_{x}$, oxygen $\left(\mathrm{O}_{2}\right)$, carbon dioxide $\left(\mathrm{CO}_{2}\right)$, carbon monoxide ( $\left.\mathrm{CO}\right)$, and opacity. The boiler parameters are monitored by $B \& W$ using a computer-based data acquisition system (DAS) known as the Boiler Performance Diagnostic System 140. Up to 1000 data points are scanned and recorded on magnetic media every 60 seconds. System 140 also performs several hundred data calculations using the input measurements. All flue gas component concentrations - $\mathrm{SO}_{2}, \mathrm{NO}_{x}, \mathrm{CO}, \mathrm{O}_{2}$, and $\mathrm{CO}_{2}-$ are monitored at the ESP outlet. Radian also monitors and records component concentrations with a separate personal computer (PC)-based DAS. Data from both DAS's are used in determining stack gas emission rates.

\subsection{Project Design and Background}

The EPA LIMB Demonstration was initiated in September 1984. B\&W, as the prime contractor, has subcontracted with Radian Corporation to perform environmental monitoring throughout the Demonstration. The following testing phases were conducted during the EPA Demonstration: 


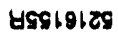

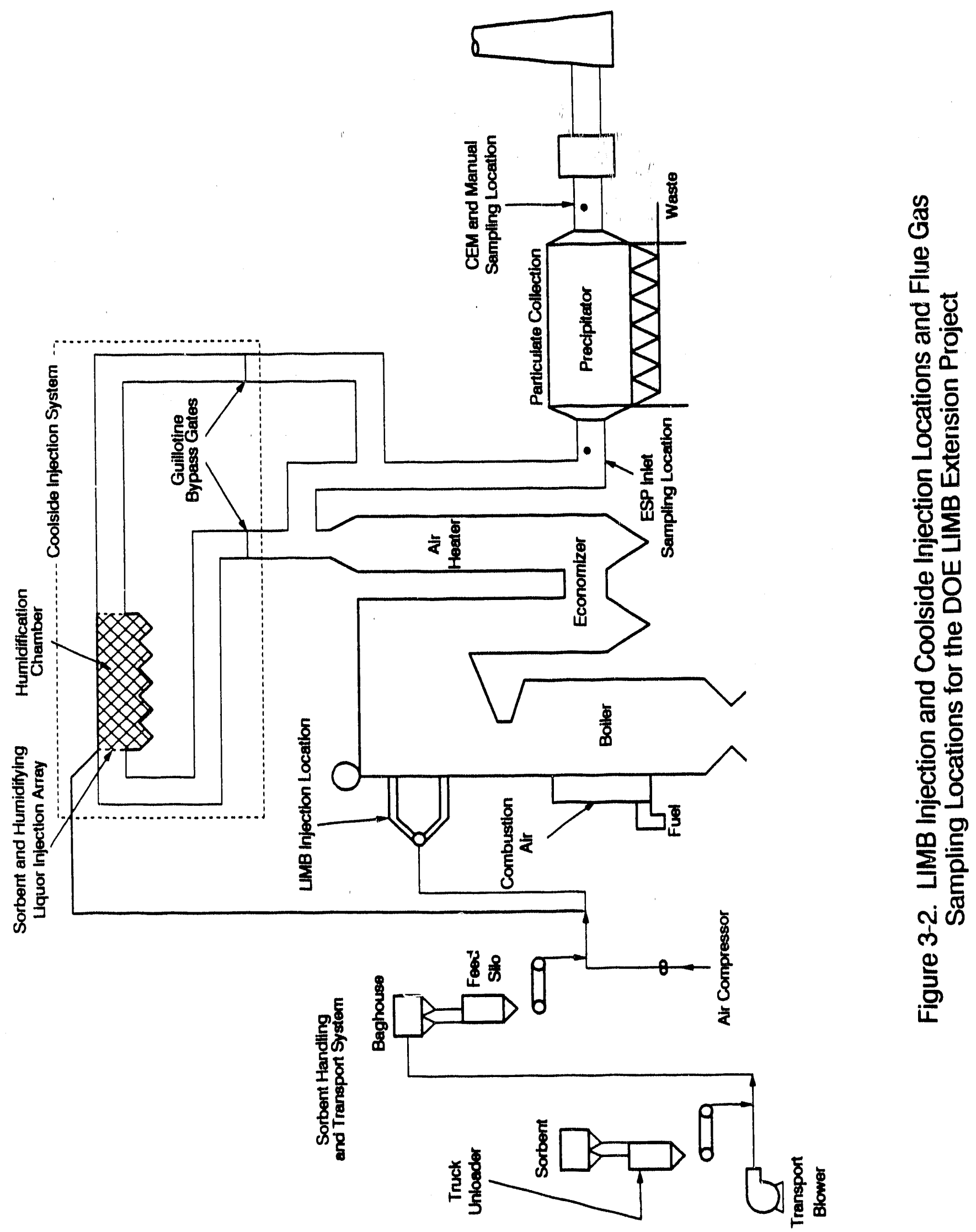


Baseline Tests - Conducted prior to any modifications to Unit No. 4. The term "Baseline" in this report also refers to a period when sorbent was not injected into Boiler No. 13 or downstream ductwork.

Low NO $\mathrm{N}_{\mathbf{x}}$ Burner Tests - Conducted after installation of the low- $\mathrm{NO}_{\mathrm{x}}$ burners.

LIMB Optimization and Demonstration - Conducted after installation of the boiler sorbent injection system. Final testing of this phase was completed with the bypass humidification chamber in place.

Preparation for the DOE sponsored LIMB Demonstration with the Coolside testing configuration started in July 1989. A shakedown period was conducted for several months to determine optimum operating conditions. The DOE Coolside tests started in October 1989 and were completed on February 16, 1990. During the period from February 17 to April 22, 1990, a non-LIMB operation or Baseline period was in progress. Following the Baseline period, the DOE LIMB Demonstration Project Extension commenced. The Extension involves sorbent injection into the boiler in conjunction with the humidification chamber operation to maintain ESP performance. When load conditions permit, tests are run close to saturation.

\subsection{Project Status}

Coolside process tests ended on February 16, 1990. During the weeks following, the system was reconfigured to accommodate boiler injection. The Baseline period occurred from February 17 to April 22, 1990. An equipment/operational shakedown period then followed, during which lignosulfonated lime was used while nominal 3.0 percent sulfur coal was burned. This condition was chosen in order to establish that the system would perform as it had prior to the Coolside test period.

The LIMB Extension system was started on April 23, 1990. System performance was monitored in the April to July 1990 reporting period for the following sorbent/coal combinations: (1) lignosulfonated lime/nominal 3.0 percent sulfur coal; 
(2) limestone/nominal 3.0 percent sulfur coal; and (3) limestone/nominal 1.6 percent sulfur coal. The system was then shut down on July 21, 1990 for a scheduled maintenance outage.

The LIMB Extension system was again started on August 14, 1990. When low sulfur coal was burned, a number of short sorbent/coal injection test periods (each less than 8 hours per day) followed, a format which has continued to date. When high sulfur coal was burned, the injection system was run full-time and data were collected continuously. The coal and sorbent combinations tested during the August to October 1990 reporting period were: (1) dolomitic lime/nominal 1.6 percent sulfur coal; and (2) dolomitic lime/nominal 3.0 percent sulfur coal. The coal and sorbent combinations tested during the November and December 1990, and January 1991 reporting period were: (1) dolomitic lime/nominal 1.6 sulfur coal; (2) dolomitic lime 3.0 percent sulfur coal; (3) dolomitic lime/nominal 3.8 percent sulfur coal; and (4) limestone/nominal 1.6 percent sulfur coal.

The LIMB system was operated this reporting period to evaluate the flue gas desulfurization efficiency of two calcium-based sorbents (dolomitic lime and lignosulfonated lime) during the combustion of two different sulfur content coals (nominal 1.6 and 3.8 percent sulfur by weight). The following three sorbent/coal combinations were evaluated during three injection periods:

- dolomitic lime/nominal 3.8 percent sulfur coal, February 4 - 20, 1991;

- lignosulfonated lime/nominal 1.6 percent sulfur coal, February 21 - April 5, 1991; and

- lignosulfonated lime/nominal 3.8 percent sulfur coal, April 6 - 30, 1991. 


\subsection{SOURCE MONITORING}

The Edgewater facility has several environmental discharge streams that are affected by the DOE LIMB program. This section divides the discharge source monitoring reporting into three areas. Unit No. 4 gaseous emissions are covered in Section 4.1, wastewater discharges are covered in Section 4.2, anc solid waste discharges are covered in. Section 4.3. Monitoring of pollution control limits and equipment is discussed in Section 4.4.

\subsection{Gaseous Emissions Monitoring}

There are two stacks at the Edgewater facility. Exhaust gases from Unit No. 4 are emitted through a stack located on the roof of the Unit No. 4 boiler house. Unit No. 3 flue gases are emitted through a brick chimney located adjacent to the northern side of the boiler house. As a part of the DOE LIMB Extension test matrix, Unit No. 4 flue gas concentrations of $\mathrm{NO}_{x}, \mathrm{SO}_{2}, \mathrm{CO}, \mathrm{CO}_{2}$, and $\mathrm{O}_{2}$ as well as opacity measurements are continuously monitored. No manual stack gas tests were conducted for total particulate matter (PM), total particulate matter below 10 microns $\left(\mathrm{PM}_{10}\right)$ and particle size distribution tests.

A summary of average air emissions data are presented in Table 4-1, by test period. Average values in the table for the three coal/sorbent combinations and the overall reporting period average are arithmetic means of nonzero daily values recorded or calculated on days when Unit No. 4 and the sorbent injection equipment were operating at least some period of time. The goal of the demonstration program is to test a wide range of operating conditions, therefore, these averages should not be taken as representative of long-term, optimized operations. For this reason, ranges of $\mathrm{SO}_{2}$ data have been shown and may include both injection and noninjection periods within a given day. A detailed analysis that breaks down emission monitoring data into shorter averaging periods is outside the scope of the EMP reporting requirements. 
TABLE 4*1. SUMMARY OF AVERAGE AIR EMISSIONS DATA

\begin{tabular}{|c|c|c|c|c|c|c|c|c|}
\hline & $\begin{array}{c}\text { Average } \\
\text { Coal } \\
\text { Firing } \\
\text { Rate } \\
\text { (klb/hr) } \\
\end{array}$ & $\begin{array}{l}\text { Average } \\
\text { Higher } \\
\text { Heating } \\
\text { Value } \\
(B+u / / b)\end{array}$ & $\begin{array}{c}\text { Average } \\
\text { Opacity } \\
(\%) \\
\end{array}$ & $\begin{array}{l}\text { Average, Ma } \\
\text { Minimum SO }\end{array}$ & $\begin{array}{l}u m \text { and } \\
\text { Emission }\end{array}$ & $\begin{array}{l}\text { Median, Maximum } \\
\text { \& Minimum } \mathrm{SO}_{2} \\
\text { Removal Efficiency } \\
(\%)^{c}\end{array}$ & $\begin{array}{l}\text { Average, M } \\
\text { Minimum NO }\end{array}$ & $\begin{array}{l}\text { mum \& } \\
\text { Emissions }\end{array}$ \\
\hline \multicolumn{9}{|c|}{ Dolomitic Lime/Nominal 3.8 Percent Sulfur Coal: 02/04 through 02/20/91. } \\
\hline $\begin{array}{l}\text { Average } \\
\text { Maximum } \\
\text { Minimum }\end{array}$ & 49 & 12,355 & 3,6 & $\begin{array}{l}3.6 \\
4.4 \\
2.1 \\
\end{array}$ & $\begin{array}{l}2,200 \\
3,400 \\
1,000 \\
\end{array}$ & $\begin{array}{l}23 \\
34 \\
21 \\
\end{array}$ & $\begin{array}{l}0.42 \\
0.47 \\
0.36 \\
\end{array}$ & $\begin{array}{l}250 \\
430 \\
170 \\
\end{array}$ \\
\hline \multicolumn{9}{|c|}{ Lignosulfonated Lime/Nominal 1.6 Percent Sulfur Coal: $02 / 21$ through $04 / 05 / 91$. } \\
\hline $\begin{array}{l}\text { Average } \\
\text { Maximum } \\
\text { Minimum } \\
\end{array}$ & 53 & 12,431 & 2.4 & $\begin{array}{l}2.2 \\
3.3 \\
1.5 \\
\end{array}$ & $\begin{array}{r}1,500 \\
2,200 \\
900 \\
\end{array}$ & $\begin{array}{r}23 \\
73 \\
9 \\
\end{array}$ & $\begin{array}{l}0.37 \\
0.44 \\
0.30 \\
\end{array}$ & $\begin{array}{l}250 \\
330 \\
160 \\
\end{array}$ \\
\hline \multicolumn{9}{|c|}{ Lignosulfonated Lime/Nominal 3.8 Percent Sulfur Coal: 04/06 through 04/30/91. } \\
\hline $\begin{array}{l}\text { Average } \\
\text { Maximum } \\
\text { Minimum } \\
\end{array}$ & 52 & 12,269 & 1.5 & $\begin{array}{l}3.4 \\
4.1 \\
2.9 \\
\end{array}$ & $\begin{array}{l}2,200 \\
3,100 \\
1,500 \\
\end{array}$ & $\begin{array}{l}39 \\
56 \\
33 \\
\end{array}$ & $\begin{array}{l}0.41 \\
0.43 \\
0.38 \\
\end{array}$ & $\begin{array}{l}260 \\
360 \\
180 \\
\end{array}$ \\
\hline \multicolumn{9}{|c|}{ Overall Reporting Period Average 02/144 through 04/30/91. } \\
\hline $\begin{array}{l}\text { Mverage } \\
\text { Maximum } \\
\text { Minimum } \\
\end{array}$ & 55 & 12,388 & 2.3 & $\begin{array}{l}2.8 \\
4.4 \\
1.5 \\
\end{array}$ & $\begin{array}{r}1,900 \\
3,400 \\
880 \\
\end{array}$ & $\begin{array}{r}23 \\
73 \\
9 \\
\end{array}$ & $\begin{array}{l}0.40 \\
0.48 \\
0.30 \\
\end{array}$ & $\begin{array}{l}280 \\
430 \\
160 \\
\end{array}$ \\
\hline \multicolumn{9}{|c|}{ Baseline Period: $02 / 17$ through $04 / 22 / 90{ }^{d}$} \\
\hline $\begin{array}{l}\text { Average } \\
\text { Maximum } \\
\text { Minimum } \\
\end{array}$ & 53 & 11,680 & 1.3 & 1.4 & 932 & $N A^{e}$ & 0.28 & 181 \\
\hline
\end{tabular}

a All emissions are calculated for wach day, as shown in Appendix A. The values represent the average of those daily calculated values. Average $\mathrm{lb} / \mathrm{hr}$ values for each reporting period can be verifled using the formula in footnote "b".

b Values calculated as $\mathrm{lbs} / \mathrm{hr}=\left[(\mathrm{lbs} / \mathrm{MMBtu})(\mathrm{klb} / \mathrm{hr})(\mathrm{Btu} / \mathrm{lb})(1000 \mathrm{lb} / \mathrm{klb}) /\left(10^{6} \mathrm{Btu} / \mathrm{MMBtu}\right)\right]$.

c Values presented here are not a direct indication of system performance. Calculations incorporate recorded data taken only during days when there was at least some LIMB operation. Zero values for off-line days were not used in calculating averages.

d The data for baseline period results are presented in the report for the period of February, March and April 1990.

e $N A^{\prime}=$ Not applicable. 
The summary of average air emissions data for the Baseline period are also arithmetic means of daily values recorded or calculated on days when Unit No. 4 was operating. However, the quality of these arithmetic means cannot be verified. As a result, the Baseline emission averages presented in Table 4-1 may be lower than actual emissions. An indication of $\mathrm{NO}_{\mathrm{x}}$ emissions prior to the demonstration can be found in the technical paper "Operation of the LIMB/Humidifter Demonstration at Edgewater," presented at the First Combined FGD and Dry $\mathrm{SO}_{2}$ Control Symposium, October 25, 1988, St. Louis, MO. This paper indicates that with B\&W XCL burners, $\mathrm{NO}_{\mathrm{x}}$ emissions range from $0.39 \mathrm{lb} \mathrm{NO} / \mathrm{MMBtu}$ at a main steam flow of $425,000 \mathrm{lb} / \mathrm{hr}$, to $0.48 \mathrm{lb}$ $\mathrm{NO}_{x} / \mathrm{MMBtu}$ at a main steam flow of $775,000 \mathrm{lb} / \mathrm{hr}$.

Air emissions data for $\mathrm{O}_{2}$ and $\mathrm{CO}_{2}$ are not included in the summary table, since they are not considered pollutants. Data for $\mathrm{CO}$ is only used as a measurement of combustion efficiency and is therefore also not included in the summary tables. Monitoring data for $\mathrm{O}_{2}, \mathrm{CO}_{2}$, and $\mathrm{CO}$ are only evaluated and reported if modeled ambient air concentrations of $\mathrm{SO}_{2}$ or $\mathrm{NO}_{x}$ are higher than the NAAQS. The results from total hydrocarbon (THC) testing, which were below 1 ppmv for the U.S. EPA portion of the Base LIMB Testing projecr (Baseline Report, 1988), demonstrated that no further THC monitoring was required.

The testing which occurred during this reporting period was largely performed during short time periods (2 to 6 hours per day). This method of testing was employed throughout most of this reporting period. However, when high sulfur coal was burned, testing took place continuously.

The $\mathrm{SO}_{2}$ mass emission rate during this reporting period varied from 880 to $3,400 \mathrm{lb} / \mathrm{hr}$. The average $\mathrm{SO}_{2}$ mass emission rate was highest during the dolomitic lime/nominal 3.8 percent sulfur coal and lignosulfonated lime/nominal 3.8 percent sulfur coal injection periods, and was the lowest during the lignosulfonated lime/nominal 1.6 percent sulfur coal injection period. The average $\mathrm{SO}_{2}$ mass emission rate for each 
injection period, which ranged from 1,500 to $2,200 \mathrm{lb} / \mathrm{hr}$, was higher than average $\mathrm{SO}_{2}$ emissions during the Baseline period of $932 \mathrm{lb} / \mathrm{hr}$. The median $\mathrm{SO}_{2}$ removal efficiency was highest during the lignosulfonated lime/noninal 3.8 percent sulfur coal injection period and lowest during the dolomitic lime/nominal 3.8 percent sulfur coal and lignosulfonated lime/nominal 1.6 percent sulfur coal injection periods. $\mathrm{SO}_{2}$ removal efficiencies for the reportitı period varied widely, from 9 to 73 percent.

The average $\mathrm{NO}_{x}$ mass emission rates for the three sorbent/coal combinations ranged from 160 to $430 \mathrm{lb} / \mathrm{hr}$ this reporting period. The average $\mathrm{NO}_{x}$ mass emission rates for each injection period, which ranged from 250 to $260 \mathrm{lb} / \mathrm{hr}$, were greater than the Baseline average $\mathrm{NO}_{x}$ emissions of $181 \mathrm{lb} / \mathrm{hr}$. With the installation of $\mathrm{B} \& \mathrm{~W}$ XCL low- $\mathrm{NO}_{\mathrm{x}}$ burners, $\mathrm{NO}_{\mathrm{x}}$ emissions during this reporting period have decreased when compared with emissions which occurred prior to the EPA LIMB Demonstration. Ambient air impacts from $\mathrm{SO}_{2}$ and $\mathrm{NO}_{x}$ emissions during these three injection periods will be evaluated in the next report.

The average opacity during each dolomitic lime injection period ranged from 1.5 to 3.6 percent, as compared to average opacity during the Baseline period of 1.3 percent. The opacity remained well below the State of Ohio permit limit of 20 percent. The average opacity during all injection periods was slightly higher than the average opacity during the Baseline period. The average higher heating value (HHV) of the coal increased this reporting period over the Baseline period.

Daily emission rate data are presented in Appendix A. No manual flue gas testing was conducted for PM and particle size distribution during this reporting period. This type of testing has been previously performed and reported in LIMB Demonstration Extension: Emission Test Report Calcium Chloride Injection Study and the Draft LIMB Demonstration Extension Quality Assurance Project Plan. Testing for PM and $\mathrm{PM}_{10}$ requires that the boiler and air pollution control equipment be operating at steady conditions for a minimum of 4 and 24 hours respectively. The injection of sorbent in 
4-8 hour periods precluded the $\mathrm{PM}$ or $\mathrm{PM}_{10}$ tests from being performed on a regular basis.

\subsection{Wastewater Monitoring}

The wastewater discharge points at the Edgewater facility are shown in Figure 4-1. The wastewater Outfalls are listed below:

1. Outfall 001 - consists of condenser cooling water and discharges to Lake Erie.

2. Outfall 002 - consists of intermittent storm water runoff from the fuel tank spill containment basin area, and also discharges to Lake Erie.

3. Outfall 601 - discharges secondary ash pond effluent. Outfall 601 consists of all major plant wastewater streams and storm water runoff, including runoff from the truck loading area.

4. Outfall 606 - consists of intermittent boiler blowdown discharge and drains to the Outfall 001 tunnel.

Orily Outfall 601 contains any additional effluent or pollutant loadings as a result of the Coolside or LIMB Demonstration Project Extension testing. Compliance monitoring was conducted as required by the NPDES permit. Monthly discharge reports are submitted by Ohio Edison to the Ohio EPA for Outfalls 601, 606, 001, and 002 for the following parameters: $\mathrm{pH}$, total suspended solids (TSS) (referred to in the permit as nonfilterable residue), flow, oil and grease (O\&G), $\mathrm{P}$, and As. TSS, $\mathrm{pH}$, and flow were measured twice a week; O\&G, and As were measured once a month. Total $P$ was not analyzed during this reporting period. Outfall 601 was monitored daily for $\mathrm{pH}$ and temperature. Daily wastewater samiples were also composited during the three sorbent/coal combinations for Ca analyses. Appendix B provides NPDES analytical data for the months of February, March and April 1991. 


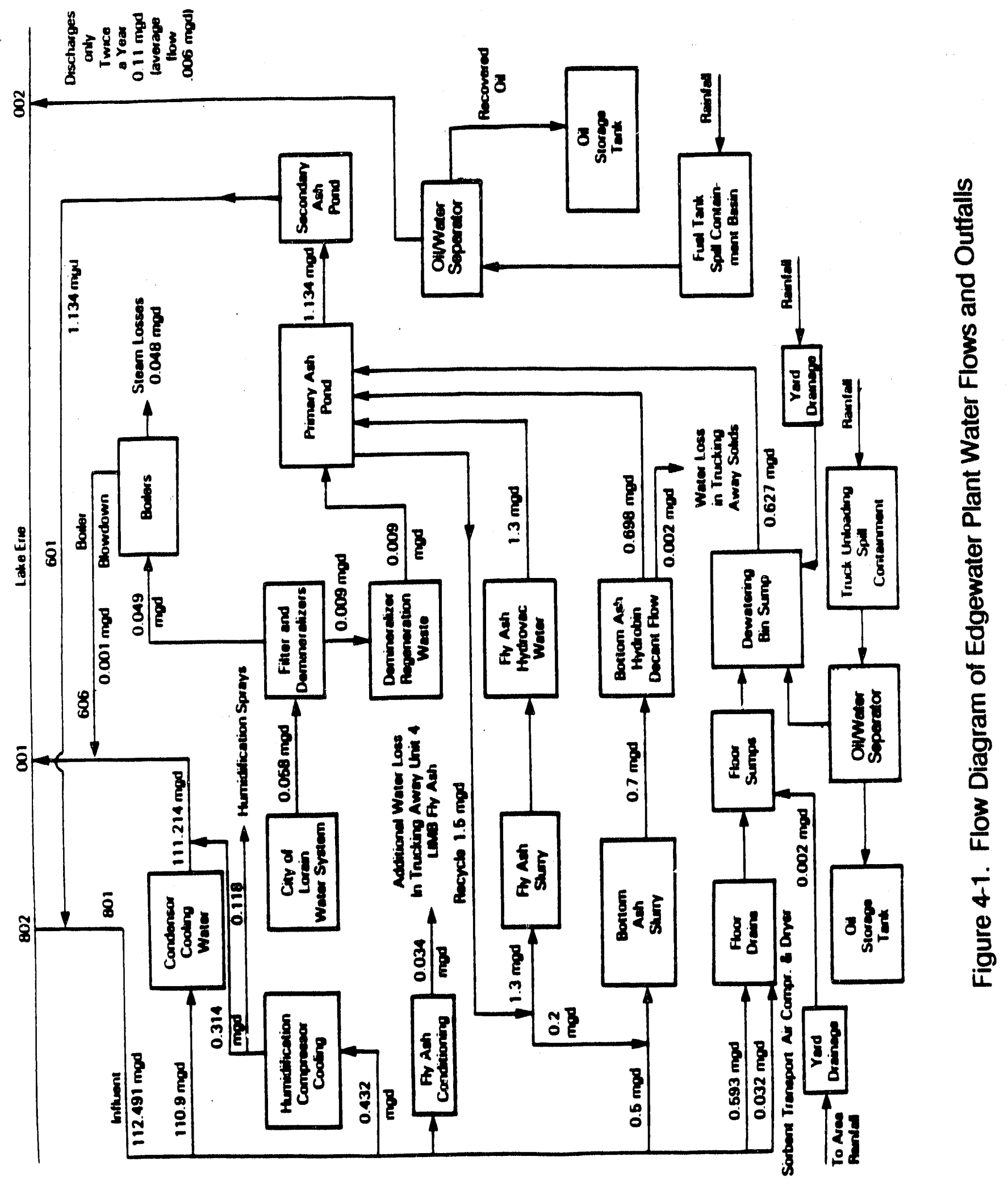


Temperature and $\mathrm{pH}$ data are shown in Appendix $\mathrm{C}$ for the period of February, March and April 1991. The Outfall $601 \mathrm{Ca}$ analyses are shown in Appendix D.

Wastewater discharges at Outfall 601 were monitored during this reporting period. All discharge parameters were within NPDES permit requirements. Table 4-2 shows a comparison of the Baseline values versus the average, maximum, and minimum values for each parameter during the month indicated. Table 4-3 provides Outfall 601 wastewater quality data categorized by sorbent/coal combination. Table 4-4 presents the supplemental $\mathrm{pH}$ and $\mathrm{Ca}$ concentration data for Outfall 601 with the data categorized by sorbent/coal combination. It is important to note that Radian and Ohio Edison perform wastewater $\mathrm{pH}$ monitoring at different locations and times. As specified in the EMP, Radian takes daily $\mathrm{pH}$ measurements at the 601 outfall into Lake Erie. Ohio Edison monitors the $\mathrm{pH}$ as the wastewater flows from the primary settling pond to the secondary settling pond. Because of the differences in time and location of data collection, $\mathrm{pH}$ measurements are likely to differ. The $\mathrm{pH}$ may change as operations change at the facility. For example, the $\mathrm{pH}$ may fluctuate in the settling ponds when ash trucks are loaded or sorbent is unloaded. Therefore, the values in Tables 4-3 and 4-4, hence Appendix B and C, are not necessarily the same. Generally, the pH data in the two tables are within $0.5 \mathrm{pH}$ units, a variation that is expected in neutral wastewater.

In addition, the monitoring data summarized in each report is from a variety of sources. Depending on the medium being sampled and the type of monitoring being performed, the dates of sampling may not match the sorbent/coal injection period. The dates of air emission and wastewater sampling recorded in Tables 4-1 and 4-3 match the injection period. The sampling dates recorded in Table 4-4, however, differ from other sampling episodes, in that wastewater samples are being composited for calcium analyses on a weekly basis (as per the EMP). Therefore, if a sorbent/coal injection period does not start on a Monday, then the injection period will not match the sampling period. 
TABLE 4-2. NPDES OUTFALL 601 MONITORING DATA FEBRUARY, MARCH AND APRIL 1991

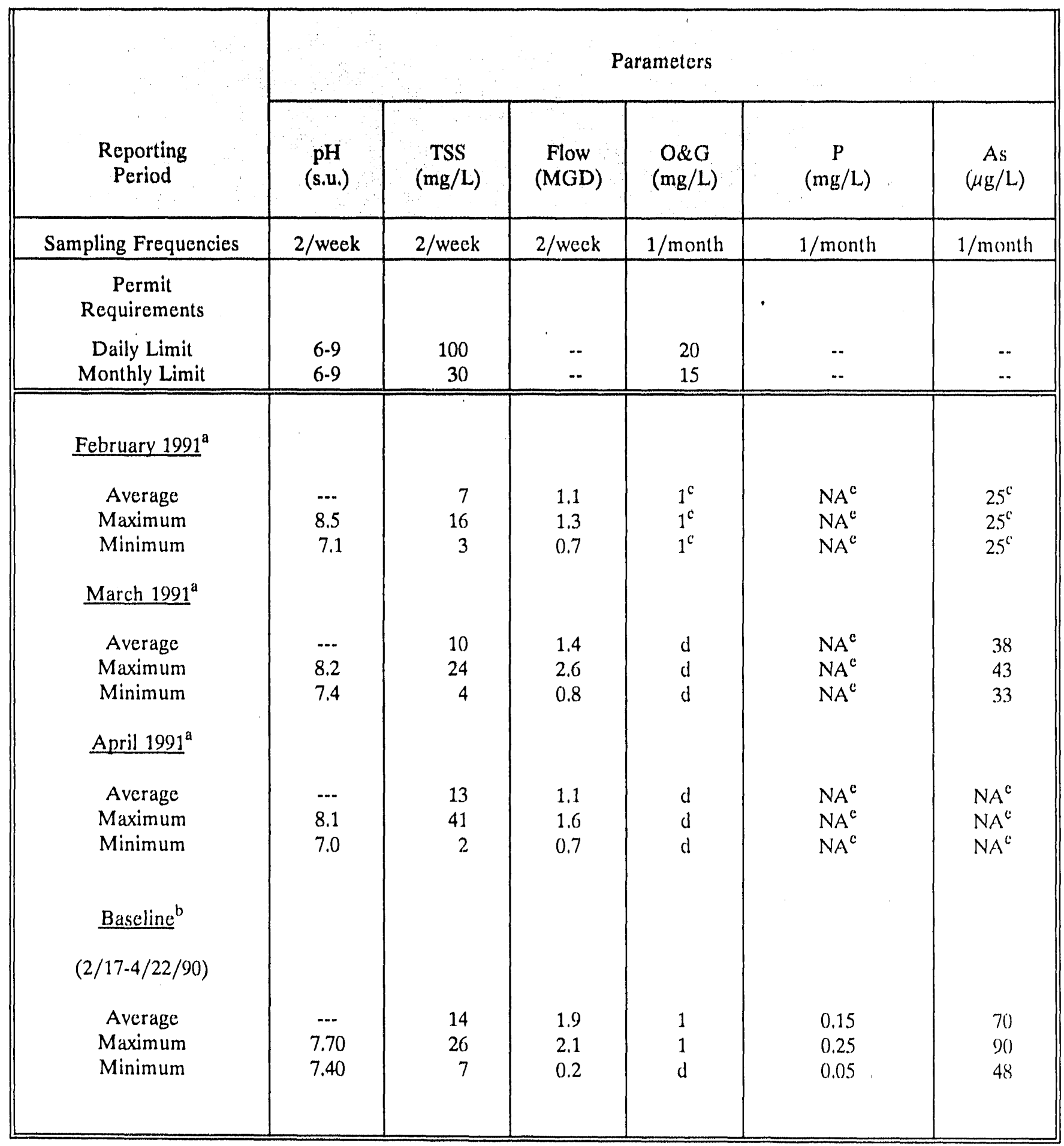

Analytical data shown in Appendix B.

Analytical data from February, March and April 1990 Reporting Period.

Single data point for the month.

Below detection limits.

Not analyzed during test period. 


\section{TABLE 4.3. SUMMARY OF NPDES OUTFALL 601 MONITORING DATA DURING BASELINE AND EXTENSION PERIODS OF OPERATIONS}

\begin{tabular}{|c|c|c|c|c|c|c|}
\hline \multirow{2}{*}{$\begin{array}{c}\text { Reporting } \\
\text { Period } \\
\text { Average, } \\
\text { Maximum, and } \\
\text { Minimum } \\
\end{array}$} & \multicolumn{6}{|c|}{ Parameters } \\
\hline & $\begin{array}{c}\mathrm{pH} \\
\text { (s.u.) }\end{array}$ & $\begin{array}{c}\text { TSS } \\
(\mathrm{mg} / \mathrm{L})\end{array}$ & $\begin{array}{l}\text { Flow } \\
\text { (MGD) }\end{array}$ & $\begin{array}{c}\text { O\&G } \\
(\mathrm{mg} / \mathrm{L})\end{array}$ & $\begin{array}{c}\mathbf{P} \\
(\mathrm{mg} / \mathrm{L})\end{array}$ & $\begin{array}{c}\text { As } \\
(\mu \mathrm{g} / \mathrm{L})\end{array}$ \\
\hline $\begin{array}{l}\text { Sampling } \\
\text { Frequencies }\end{array}$ & 2/week & 2/week & 2/week & $1 /$ month & $1 /$ month & $1 /$ month \\
\hline $\begin{array}{c}\text { Permit } \\
\text { Requirements } \\
\text { Daily Limit } \\
\text { Monthly Limit }\end{array}$ & $\begin{array}{l}6-9 \\
6-9\end{array}$ & $\begin{array}{c}100 \\
30\end{array}$ & $\begin{array}{l}-- \\
--\end{array}$ & $\begin{array}{l}20 \\
15\end{array}$ & -. & -. \\
\hline \multicolumn{7}{|c|}{ Dolomitic Lime/Nominal 3.8 Percent Sulfur Coal: $02 / 04$ through $02 / 20 / 91^{\text {a }}$} \\
\hline $\begin{array}{l}\text { Average } \\
\text { Maximum } \\
\text { Minimum }\end{array}$ & $\begin{array}{l}7.6 \\
7.4\end{array}$ & $\begin{array}{l}5.5 \\
8 \\
3\end{array}$ & $\begin{array}{l}1.1 \\
1.3 \\
0.7\end{array}$ & $\begin{array}{l}1^{\mathrm{c}} \\
1^{\mathrm{c}} \\
1^{\mathrm{c}}\end{array}$ & $\begin{array}{l}N A^{b} \\
N A^{b} \\
N A^{b}\end{array}$ & $\begin{array}{l}25^{\mathrm{c}} \\
25^{\mathrm{c}} \\
25^{\mathrm{c}}\end{array}$ \\
\hline \multicolumn{7}{|c|}{ Lignosulfonated Lime/Nominal 1.6 Percent Sulfur Coal: $02 / 21$ through $04 / 05 / 91^{\mathrm{a}}$} \\
\hline $\begin{array}{l}\text { Average } \\
\text { Maximum } \\
\text { Minimum } \\
\end{array}$ & $\begin{array}{l}8.5 \\
7.1 \\
\end{array}$ & $\begin{array}{r}12 \\
41 \\
4 \\
\end{array}$ & $\begin{array}{l}1.4 \\
2.6 \\
0.8 \\
\end{array}$ & $\begin{array}{l}d \\
d \\
d\end{array}$ & $\begin{array}{l}N A^{b} \\
N A^{b} \\
N A^{b}\end{array}$ & $\begin{array}{l}38 \\
43 \\
33 \\
\end{array}$ \\
\hline \multicolumn{7}{|c|}{ Lignosulfonated Lime/Nominal 3.8 Percent Sulfur Coal: 04/06 through $04 / 30 / 91^{a}$} \\
\hline $\begin{array}{l}\text { Average } \\
\text { Maximum } \\
\text { Minimum }\end{array}$ & $\begin{array}{l}-. \\
8.1 \\
7.0\end{array}$ & $\begin{array}{r}10 \\
24 \\
2\end{array}$ & $\begin{array}{l}1.0 \\
1.5 \\
0.7\end{array}$ & $\begin{array}{l}N A^{b} \\
N A^{b} \\
N A^{b}\end{array}$ & $\begin{array}{l}N A^{b} \\
N A^{b} \\
N A^{b}\end{array}$ & $\begin{array}{l}N A^{b} \\
N A^{b} \\
N A^{b}\end{array}$ \\
\hline \multicolumn{7}{|c|}{ Overall Reporting Period Average: $02 / 01$ through $04 / 30 / 91^{\mathrm{a}}$} \\
\hline $\begin{array}{l}\text { Average } \\
\text { Maximum } \\
\text { Minimum }\end{array}$ & $\begin{array}{l}8.5 \\
7.0\end{array}$ & $\begin{array}{r}10 \\
41 \\
2 \\
\end{array}$ & $\begin{array}{l}1.2 \\
2.6 \\
0.7\end{array}$ & $\begin{array}{l}1 \\
1 \\
d\end{array}$ & $\begin{array}{l}N A^{b} \\
N A^{b} \\
N A^{b}\end{array}$ & $\begin{array}{l}34 \\
43 \\
25\end{array}$ \\
\hline \multicolumn{7}{|c|}{ Baseline Period: $02 / 17$ through $04 / 22 / 90^{c}$} \\
\hline $\begin{array}{l}\text { Average } \\
\text { Maximum } \\
\text { Minimum }\end{array}$ & $\begin{array}{l}\ddot{7.70} \\
7.40\end{array}$ & $\begin{array}{r}14 \\
26 \\
7\end{array}$ & $\begin{array}{l}1.9 \\
2.1 \\
0.2\end{array}$ & $\begin{array}{l}1.0 \\
1 \\
d\end{array}$ & $\begin{array}{l}0.15 \\
0.25 \\
0.05\end{array}$ & $\begin{array}{l}70 \\
90 \\
48\end{array}$ \\
\hline
\end{tabular}

a Analytical data shown in Appendix B.

Not analyzed during test period.

c Single data point for the period.

d Below detection limits.

e Analytical data from February, March and April 1990 Reporting Period. 


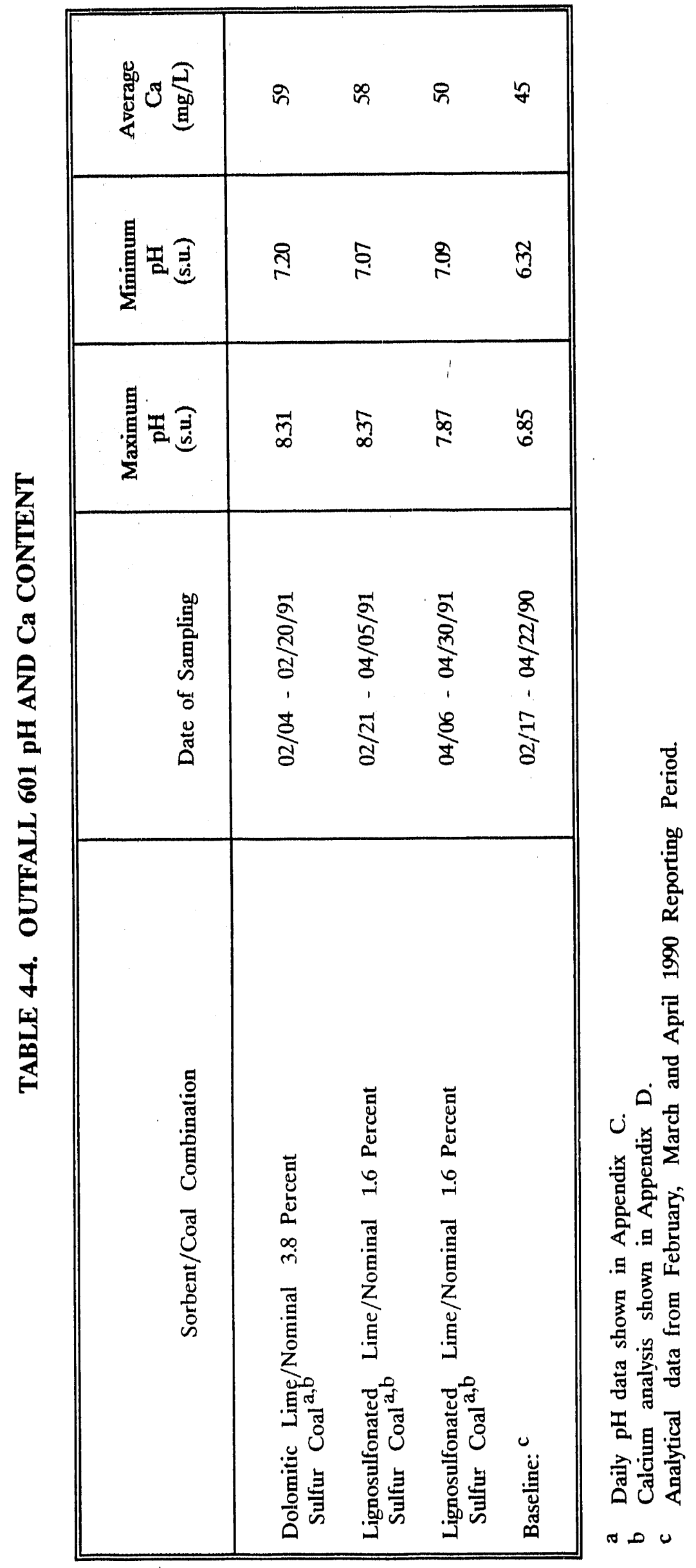


The maximum and minimum $\mathrm{pH}$ measurements recorded during the three sorbent/coal combinations were greater than the maximum and minimum $\mathrm{pH}$ measurements recorded during the Baseline period. The wastewater $\mathrm{Ca}$ concentration values ranged from 50 to $59 \mathrm{mg} / \mathrm{L}$ during the reporting period. The average, maximum, and minimum concentration of As during the dolomitic lime/nominal 3.8 percent sulfur coal and lignosulfonated lime/nominal 1.6 percent sulfur coal injection period were below Baseline values. The TSS average and minimum concentrations during this reporting period were at or below Baseline levels, however, the maximum concentration was higher than Baseline. The average and maximum $O \& G$ concentrations reported this period increased when compared to the Baseline. However, the increase in the O\&G concentration was well below permit requirements and these $O \& G$ values were measured very near the stated detection limit of $1 \mathrm{mg} / \mathrm{l}$. No $P$ analyses were performed during this reporting period.

\subsection{Solid Waste Discharges}

The two solid waste streams generated from coal combustion at the Edgewater facility are boiler bottom ash and fly ash. A generalized schematic of the ash handling system is presented in Figure 4-2. Bottom ash generated during the project is not expected to present a major environmental impact. The bottom ash will not be analyzed, since LIMB Extension activities will not impact bottom ash generation and the quantity of bottom ash generated is a small percentage of the total ash produced. Only fly ash will be sampled and analyzed during the LIMB Extension periods of operation. The fly ash was sampled and analyzed during the dolomitic lime/nominal 3.8 percent sulfur coal and the dolomitic lime/nominal 1.6 percent sulfur coal injection periods. The dolomitic lime/3.8 percent sulfur coal ash sample was composited from October 8 to November 27, 1991. The dolomitic lime/1.6 percent sulfur coal ash sample was composited from November 28 to December 20, 1990. 


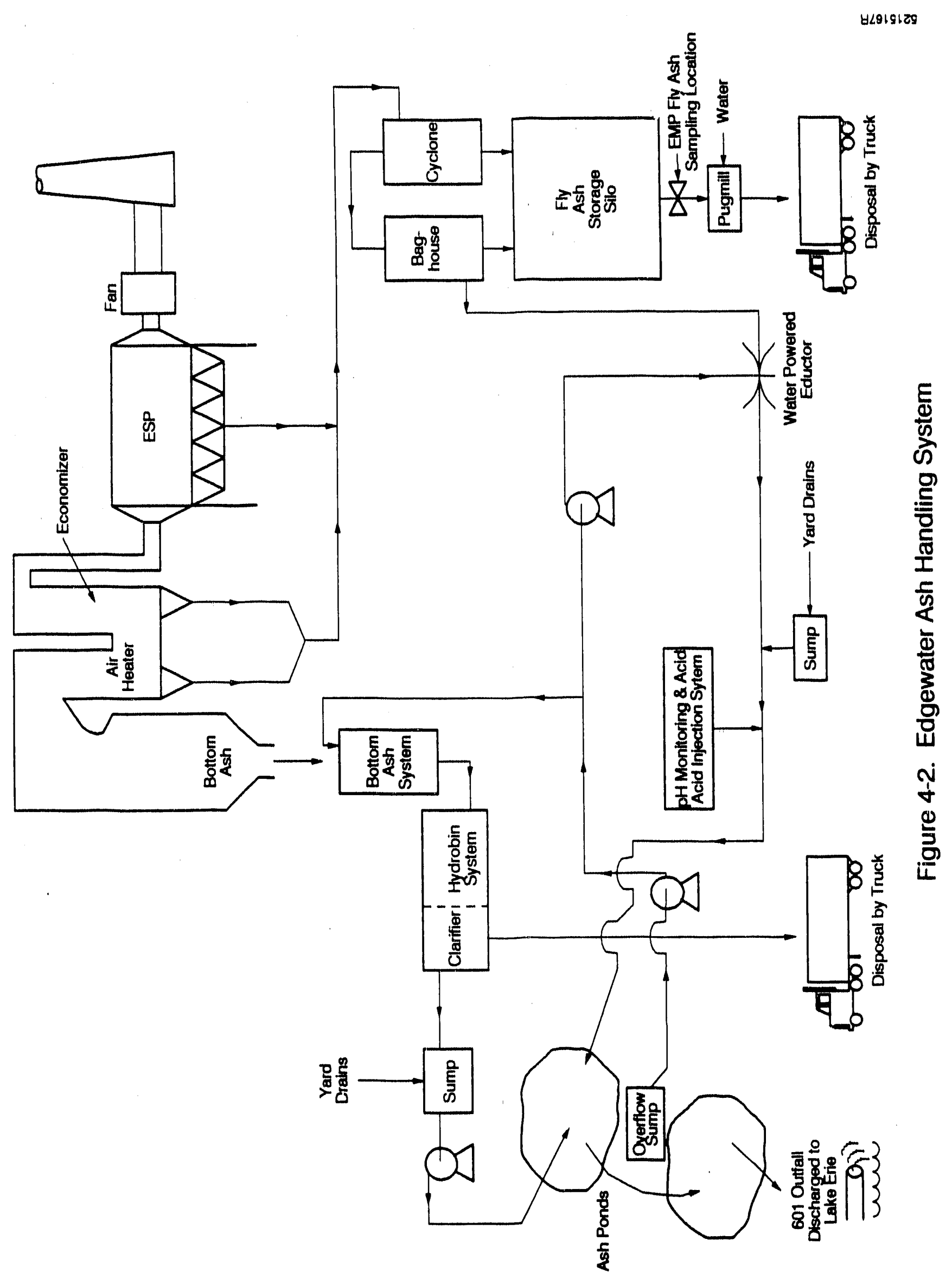


During August and September 1990, lime injection was limited to daily test periods. Because these injection periods were so short, it was not possible to collect representative ash samples from the electrostatic precipitator (ESP) during these injection and non-injection periods. In October 1990, the testing program continued with short duration injection periods. At that time, Radian decided to attempt collection of representative ash samples from the ESP and from the ash truck loading chute. Fly ash, which was removed from the flue gas by the ESP and air heater/economizer, was sampled daily at the bottom of the ash storage silo.

The analyses on the composite ash sample produced for each sorbent/coal injection period will be compared to the results from the Baseline ash sample. The Baseline ash sample was composited from samples collected from February 17 through April 22, 1990.

As a part of the EMP, the fly ash generated during the LIMB Extension activities is subjected to the TCLP and the DI leaching procedure (ASTM 3987), with analysis of the DI leachate for 28 targeted parameters. Utility waste, such as fly ash, is an exempt category under the Resource Conservation and Recovery Act (RCRA), therefore leaching tests are not mandated to characterize a waste prior to disposal. However, the EMP specifies performing the TCLP and ASTM 3987 DI leaching procedures to provide an initial indication of leachate strength when the ash is disposed of in a sanitary landfill or monofill.

The TCLP and DI leaching procedures generate leachates from solid wastes, which are then analyzed for metals and inorganic elements and compounds. The fly ash samples generated during the LIMB Extension activities were leached using both procedures. The leachate from each DI procedure is analyzed for 23 targeted parameters and the TCLP for 8 parameters. Prior to March 1990, RCRA stipulated that the Extraction Procedure (EP) Toxicity Test be used to assess the toxicity characteristics of a solid waste. EPA promulgated a new toxicity characteristics ruling in March 1990 
requiring that the TCLP replace the EP toxicity test. To ensure regulatory compliance during the Baseline period, ash composited during this period was subjected to the EP Toxicity Test and the TCLP as well as the DI leaching procedure. After the Baseline period, the EP toxicity test was no longer used and the ashes generated during the Extension periods of operation were leached using the TCLP and the DI procedures only. All extraction procedures and reference methods are provided in Appendix E.

The leachates from the TCLP and the DI leaching procedure were analyzed for the eight RCRA-regulated metals [silver $(\mathrm{Ag})$, As, barium (Ba), cadmium $(\mathrm{Cd})$, chromium $(\mathrm{Cr})$, mercury $(\mathrm{Hg})$, lead $(\mathrm{Pb})$, and selenium $(\mathrm{Se})]$. The TCLP and the EP Toxicity Tests are acid extractions $(\mathrm{pH}<5.0)$ and are not suitable for the non-metal analyses. Therefore, a neutral leaching procedure was selected (ASTM D3987) to produce a leachate to monitor for the following secondary constituents: total phenolics, $\mathrm{pH}, \mathrm{Ca}$, chloride $(\mathrm{Cl})$, fluoride $(\mathrm{Fl})$, potassium $(\mathrm{K})$, sodium $(\mathrm{Na})$, nitrate, sulfate, total hardness, total alkalinity, acidity, bicarbonate, carbonate, chemical oxygen demand (COD), total organic carbon (TOC), total dissolved solids (TDS), iron, and copper.

The corrosivity and permeability results on the composite samples from the two sorbent/coal injection periods are compared to the Baseline in Table 4-5. Tests of the Baseline ash demonstrated a corrosivity of $1.3 \mathrm{~mm} / \mathrm{yr}$. Corrosivities of both ash samples were below the detection limits for the test. The permeability of the ash from each of the two sorbent/coal injection periods was lower than that of the Baseline ash sample. This decrease in permeability was expected, since the two sorbents can act as a cement material. This characteristic is advantageous in a landfill because it demonstrates a decreased tendency for leachate to flow through the spent sorbent/ash matrix. The permeability data summary is provided in Appendix G.

The analytical results for metals and secondary analytes from the two sorbent/coal injection periods are compared to the Baseline concentrations in Table 4-6. The concentrations of metals for the two injection periods, both TCLP and DI leachates, 
TABLE 4-5. ESP ASH CORROSIVITY AND PERMEABILITY RESULTS

\begin{tabular}{|c|c|}
\hline \multicolumn{2}{|c|}{ Dolomitic Lime/Nominal 3.8 Percent Sulfur Coal ${ }^{\mathrm{a}}$} \\
\hline Parameter & Results \\
\hline Corrosivity $^{b}$ & c \\
\hline Permeability & $1.3 \times 10^{-5} \mathrm{~cm} / \mathrm{sec}$ \\
\hline \multicolumn{2}{|c|}{ Dolomitic Lime/Nominal 1.6 Percent Sulfur Coal ${ }^{\mathrm{a}}$} \\
\hline Parameter & Results \\
\hline Corrosivity $^{b}$ & c \\
\hline Permeability & $3.7 \times 10^{-6} \mathrm{~cm} / \mathrm{sec}$ \\
\hline \multicolumn{2}{|c|}{ Baseline $^{d}$} \\
\hline Parameter & Results \\
\hline Corrosivity $^{b}$ & $1.3 \mathrm{~mm} / \mathrm{yr}$ \\
\hline Permeability & $5.3 \times 10^{-4} \mathrm{~cm} / \mathrm{sec}$ \\
\hline
\end{tabular}

a Aralytical data shown in Appendix G.

b Conducted on DI leachate sample.

c Below detection limits.

d Analytical data from May, June and July 1990 Report. 
TABLE 4-6. ANALYSES PERFORMED ON FLY ASH LEACHATES FROM THE BASELINE AND EXTENSION PERIODS OF OPERATION

\begin{tabular}{|c|c|c|c|c|c|c|}
\hline \multirow[b]{2}{*}{ Parameter } & \multicolumn{2}{|c|}{ BASELINE ASH ${ }^{\natural}$} & \multicolumn{2}{|c|}{$\begin{array}{c}\text { DOLOMITIC } \\
\text { LIME/NOMINAL } 3,8 \\
\text { PERCENT SULFUR } \\
\text { COAL }^{\mathrm{b}} \\
\end{array}$} & \multicolumn{2}{|c|}{$\begin{array}{l}\text { DOLOMITIC } \\
\text { LIME/NOMINAL } 1.6 \\
\text { PERCENT SULFUR } \\
\text { COAL }^{b}\end{array}$} \\
\hline & $\begin{array}{c}\text { DI } \\
\text { Leachate } \\
(\mathrm{mg} / \mathrm{L}) \\
\end{array}$ & $\begin{array}{c}\text { Dl } \\
\text { Detection } \\
\text { Limit } \\
(\mathrm{mg} / \mathrm{L}) \\
\end{array}$ & $\begin{array}{c}\text { DI } \\
\text { Leachate } \\
\text { (mg/L) } \\
\end{array}$ & $\begin{array}{c}\text { DI } \\
\text { Detection } \\
\text { Limit } \\
(\mathrm{mg} / \mathrm{L}) \\
\end{array}$ & $\begin{array}{c}\text { DI } \\
\text { Leachate } \\
(\mathrm{mg} / \mathrm{L})\end{array}$ & $\begin{array}{c}\text { Dl } \\
\text { Leachate } \\
\text { Detection } \\
\text { Limit } \\
(\mathrm{mg} / \mathrm{L}) \\
\end{array}$ \\
\hline Total Phenolics & $0.023^{\mathrm{c}}$ & 0.0050 & $N D^{d}$ & 0.0050 & $0.012^{\mathrm{c}}$ & 0.0050 \\
\hline & 4.0 & -. & 12 & $\cdots$ & 12 & -. \\
\hline Calclum & 460 & 1.0 & 1500 & 10 & 1700 & 4,0 \\
\hline Chloride & $3.2^{\mathrm{C}}$ & 1.0 & 98 & 1.0 & 460 & 50 \\
\hline Fluoride & 3.3 & 0.10 & 3.8 & 0.20 & 2.3 & 0.20 \\
\hline Potassium & $N D^{d}$ & 3.0 & 23 & 3.0 & $12^{\mathrm{c}}$ & 3.0 \\
\hline Sodium & 43 & 1.0 & 9.6 & 1.0 & $4.9^{\mathfrak{c}}$ & 1.0 \\
\hline Nitratc & 0.2 & 0.020 & $N^{d}$ & 0.020 & 0.26 & 0,020 \\
\hline Sulfate & 1700 & 100 & 1000 & 100 & 1300 & 100 \\
\hline Total Hardness & 1268 & 66 & $N A^{e}$ & $\cdots$ & $N A^{\circ}$ & $N A^{c}$ \\
\hline $\begin{array}{l}\text { Total Alkalinity as } \\
\mathrm{CaCO}_{3}\end{array}$ & $N^{d}$ & 1.0 & 2300 & 1.0 & 2300 & 1.0 \\
\hline Acidity & 250 & 1.0 & $\mathrm{NA}^{\mathrm{e}}$ & -- & $N A^{c}$ & $N A^{c}$ \\
\hline Bicarbonate & $N^{d}$ & 1.0 & $N^{d}$ & -. & $N^{d}$ & $N A^{\circ}$ \\
\hline Carbonate & $N^{d}$ & 1.0 & 110 & -- & $120^{\circ}$ & -. \\
\hline $\begin{array}{l}\text { Chemical Oxygen } \\
\text { Demand (COD) }\end{array}$ & $N^{d}$ & 5.0 & $8.3^{\mathfrak{c}}$ & 5.0 & $11^{\mathrm{c}}$ & 5.0 \\
\hline $\begin{array}{l}\text { Total Organic Carbon } \\
\text { (TOC) }\end{array}$ & $2.2^{c}$ & 1.0 & $N D^{d}$ & 1.0 & $N D^{d}$ & 1.0 \\
\hline $\begin{array}{l}\text { Total Dissolved Solids } \\
\text { (TDS) }\end{array}$ & 2700 & 9.0 & 4000 & 9.0 & 5000 & 9.0 \\
\hline Iron & 3.8 & 0.040 & $N A^{e}$ & -. & $N A^{e}$ & $\cdots$ \\
\hline Copper & 1.1 & 0.020 & $N A^{e}$ & -. & $\mathrm{NA}^{\mathrm{e}}$ & -. \\
\hline Magnesium & 29 & 1.0 & $N A^{\mathrm{e}}$ & -- & $N A^{c}$ & $-\cdot$ \\
\hline Silver & $N D^{d}$ & 0,010 & $N D^{d}$ & 0.10 & $N D^{d}$ & 0.40 \\
\hline Arsenic & $0.0042^{c}$ & 0.0040 & $0.011^{\mathrm{c}}$ & 0.0040 & $0.0040^{\mathrm{c}}$ & 0.0040 \\
\hline Barium & 0.06 .2 & 0.010 & 0.60 & 0.010 & 0.48 & 0.040 \\
\hline Cadmium & 0.069 & 0.0050 & $N^{d}$ & 0.050 & $N^{d}$ & 0.020 \\
\hline Chromium & 0.27 & 0.010 & 0.030 & 0.010 & 0.29 & 0.040 \\
\hline Mercury & $N^{d}$ & 0.0002 & $N^{d}$ & 0.0002 & $N^{d}$ & 0.0002 \\
\hline Lead & $0.00097^{c}$ & 0.0030 & 0.027 & 0.0030 & $0.012^{C}$ & 0.0030 \\
\hline Sclenium & 0,059 & 0.0050 & 0.13 & 0.025 & 0,071 & 0.0050 \\
\hline
\end{tabular}

a Analytical data from May, June and July 1990 Report.

b Analytical data shown in Appendix F.

c Estimated results less than 5 times the practical quantitation limit.

d Below detection limits.

c Not analyzed. 
TABLE 4*6. (CONTINUED)

\begin{tabular}{|c|c|c|c|c|c|c|}
\hline \multirow[b]{2}{*}{ Parameter } & \multicolumn{2}{|c|}{ BASELINE ASH ${ }^{\natural}$} & \multicolumn{2}{|c|}{$\begin{array}{c}\text { DOLOMITIC } \\
\text { LIME/NOMINAL } 3.8 \\
\text { PERCENT SULLFUR } \\
\text { COAL }\end{array}$} & \multicolumn{2}{|c|}{$\begin{array}{l}\text { DOLOMITIC } \\
\text { LIME/NOMINAL } 1.6 \\
\text { PERCENT SULFUR } \\
\text { COAL } \\
\end{array}$} \\
\hline & $\begin{array}{l}\text { TCLP } \\
(\mathrm{mg} / \mathrm{L})\end{array}$ & $\begin{array}{l}\text { TCLP } \\
\text { Detection } \\
\text { Limit } \\
(\mathrm{mg} / \mathrm{L}) \\
\end{array}$ & $\begin{array}{c}\text { TCLP } \\
\text { Leachate } \\
(\mathrm{mg} / \mathrm{L})\end{array}$ & $\begin{array}{c}\text { TCLP } \\
\text { Dotection } \\
\text { Limit } \\
(\mathrm{mg} / \mathrm{L}) \\
\end{array}$ & $\begin{array}{c}\text { TCLP } \\
\text { Leachate } \\
\text { (mg/L) }\end{array}$ & $\begin{array}{l}\text { TCLP } \\
\text { Detection } \\
\text { Limit } \\
(\mathrm{mg} / \mathrm{L}) \\
\end{array}$ \\
\hline Total Phenolics & $\mathrm{NA}^{\circ}$ & $\ldots$ & $N A^{c}$ & .- & $\mathrm{NA}^{\circ}$ & - \\
\hline & $N A^{\circ}$ & $\cdots$ & $N A^{\circ}$ & -- & $\mathrm{NA}^{\mathrm{O}}$ & $\ldots$ \\
\hline Calcium & $\mathrm{NA}^{\mathrm{e}}$ & $\ldots$ & $\mathrm{NA}^{\mathrm{e}}$ & $\ldots$ & $\mathrm{NA}^{\mathrm{e}}$ & $\ldots$ \\
\hline Chloride & $\mathrm{NA}^{\mathrm{o}}$ & -. & $N A^{\circ}$ & .. & $\mathrm{NA}^{\circ}$ & $\cdots$ \\
\hline Fluoride & $N A^{\circ}$ & $\ldots$ & $\mathrm{NA}^{\circ}$ & $\ldots$ & $\mathrm{NA}^{\mathrm{e}}$ & $\ldots$ \\
\hline Potassium & $N A^{\circ}$ & .. & $N A^{e}$ & $\ldots$ & $N A^{e}$ & $\ldots$ \\
\hline Sodium & $N A^{c}$ & .. & $N A^{\circ}$ & .. & $N A^{\circ}$ & $\ldots$ \\
\hline Nitrate & $N A^{e}$ & -.. & $N A^{e}$ & .. & $N A^{\circ}$ & $\ldots$ \\
\hline Sulfate & $N A^{\circ}$ & $\cdots$ & $N A^{\circ}$ & -- & $\mathrm{NA}^{\mathrm{e}}$ & $\ldots$ \\
\hline Total Hardness & $\mathrm{NA}^{\mathrm{e}}$ & $\ldots$ & $N A^{c}$ & .. & $\mathrm{NA}^{\mathrm{o}}$ & $\ldots$ \\
\hline Total Alkalinity as $\mathrm{CaCO}_{3}$ & $\mathrm{NA}^{\circ}$ & $\cdots$ & $\mathrm{NA}^{\mathrm{e}}$ & $\ldots$ & $N A^{\mathrm{e}}$ & $\cdots$ \\
\hline Acidity & $N A^{e}$ & .. & $N A^{\circ}$ & $\ldots$ & $\mathrm{NA}^{\mathrm{c}}$ & ... \\
\hline Bicarbonate & $\mathrm{NA}^{\mathrm{a}}$ & $\ldots$ & $\mathrm{NA}^{\mathrm{e}}$ & -- & $\mathrm{NA}^{\mathrm{o}}$ & $\ldots$ \\
\hline Carbonate & $\mathrm{NA}^{\mathrm{e}}$ & -. & $N A^{\mathrm{e}}$ & .. & $N A^{\mathrm{c}}$ & .. \\
\hline $\begin{array}{l}\text { Chemical Oxygen Demand } \\
\text { (COD) }\end{array}$ & $N A^{c}$ & $\cdots$ & $N A^{c}$ & .. & $N A^{e}$ & -. \\
\hline $\begin{array}{l}\text { Total Organic Carbon } \\
\text { (TOC) }\end{array}$ & $N A^{e}$ & .. & $N A^{c}$ & .. & $N A^{e}$ & $\cdots$ \\
\hline $\begin{array}{l}\text { Total Dissolved Solids } \\
\text { (TDS) }\end{array}$ & $N A^{e}$ & $\ldots$ & $N A^{e}$ & $\ldots$ & $N A^{e}$ & -. \\
\hline Iron & $N A^{c}$ & $\ldots$ & $N A^{e}$ & $\ldots$ & $N A^{\circ}$ & .. \\
\hline Copper & $N A^{e}$ & .. & $N A^{c}$ & -- & $N A^{e}$ & .. \\
\hline Magnesium & $N A^{e}$ &.- & $N A^{\mathrm{e}}$ & -- & $\mathrm{NA}^{\mathrm{e}}$ & $\cdots$ \\
\hline Silver & $0.013^{c}$ & 0.010 & $N D^{d}$ & 0.10 & $N D^{d}$ & 0.040 \\
\hline Arsenic & 1.5 & 0.30 & $3.7^{\mathrm{c}}$ & 3.0 & $N^{d}$ & 1.2 \\
\hline Barium & 0.053 & 0.010 & 0.47 & 0.010 & 1.1 & 0.040 \\
\hline Cadmium & $0.013^{\mathrm{c}}$ & 0.0050 & $\mathrm{ND}^{\mathrm{d}}$ & 0.050 & $\mathrm{ND}^{\mathrm{d}}$ & 0.020 \\
\hline Chromium & $0.016^{\mathrm{c}}$ & 0.010 & 0.19 & 0.010 & $0.018^{\mathrm{c}}$ & 0.010 \\
\hline Mercury & $N D^{d}$ & 0.0002 & $\mathrm{ND}^{\mathrm{d}}$ & 0,0002 & $N^{d}$ & 0.0002 \\
\hline Lead & $\mathrm{ND}^{\mathrm{d}}$ & 0.050 & $\mathrm{ND}^{\mathrm{d}}$ & 0.50 & $N^{d}$ & 0.20 \\
\hline Selenium & 0.0 .58 & 0.0050 & 0.21 & 0.025 & $0.024^{c}$ & 0.0050 \\
\hline
\end{tabular}

Analytical data from May, June and July 1990 Report.

Analytical data shown in Appendix F.

Estimated results less than 5 times the practical quantitation limit.

d Below detection limits.

Nol analyzed. 
were below all TCLP MCL's, and the concentrations were below the detection limit for $\mathrm{Ag}, \mathrm{Cd}$, and $\mathrm{Hg}$.

An increase was observed in the $\mathrm{pH}, \mathrm{Ca}, \mathrm{Cl}, \mathrm{K}$, total alkalinity, and TDS concentrations for both injection periods over the Baseline. This increase was expected, due to the presence of spent sorbent material in the fly ash. A decrease was observed in the $\mathrm{Na}$, sulfate, and TOC concentrations for both injection periods over the Baseline. The Fl concentration of the dolomitic lime/nominal 3.8 percent sulfur coal injection period increased over the Baseline; whereas, the Fl concentration of the dolomitic lime/nominal 1.6 percent sulfur coal injection period decreased over the Baseline. The nitrate concentration of the dolomitic lime/nominal 3.8 percent sulfur coal injection period decreased over the Baseline; whereas, the nitrate concentration of the dolomitic lime/nominal 1.6 percent sulfur coal injection period increased over the Baseline. The analytical data summary is provided in Appendix F.

\subsection{Pollution Control Limit Monitoring}

The pollution control systems for gaseous and aqueous discharges from Unit No. 4 were continuously monitored throughout the months of February, March and April 1991. Stack gas emissions from Unit No. 4 were controlled with the LIMB system and the existing ESP.

The LIMB operating log for the months indicated is presented in Table 4-7. Some of the reasons for various outages and system upsets are included in the table. In February 1991, the system operated for a total of 384 hours of formal testing. During March 1991, no formal testing was conducted for 13 days. The system operated for 122 hours of formal testing during the month, with the system off-line clue to low power demands. In April 1991, the system operated for a total of 213 hours of formal testing. Occasional shutdowns were reported for sorbent injection line repairs, plugged sorbent injection hoses, and to "zero" monitoring equipment. 
TABLE 4-7. LIMB OPERATION LOG FOR JANUARY, FEBRUARY, MARCH, AND APRIL 1991

\begin{tabular}{|c|c|c|c|c|c|c|c|c|}
\hline \multirow[t]{2}{*}{$8=$} & \multicolumn{2}{|c|}{ \% } & \multicolumn{2}{|c|}{ 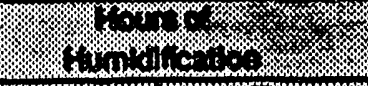 } & \multirow{2}{*}{ 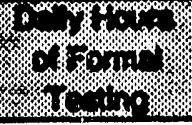 } & \multirow{2}{*}{ Ra/s } & \multirow{2}{*}{ 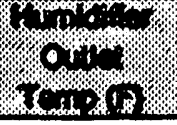 } & \multirow{2}{*}{$\begin{array}{l}\text { ont } \\
\text { rowe at } \\
\text { or anes }\end{array}$} \\
\hline & Yon: & 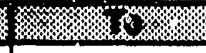 & X & 210 & & & & \\
\hline 910121 & 1000 & 1300 & - & - & 3 & 2 & - & 21 \\
\hline 910122 & 1200 & 1400 & - & - & 2 & 1.0 & - & 22 \\
\hline 910123 & \multicolumn{2}{|c|}{ LIMB unit off-line. } & & & & & & 24 \\
\hline 910124 & 1000 & 1300 & - & - & 3 & 2.0 & - & 21 \\
\hline 910125 & 1100 & 1330 & - & - & 2.5 & 1.6 & - & 21.5 \\
\hline 910126 & \multirow{2}{*}{\multicolumn{2}{|c|}{$\begin{array}{l}\text { LIMB unit off-line. } \\
\text { LIMB unit off-line. }\end{array}$}} & & & & & & 24 \\
\hline 910127 & & & & & & & & 24 \\
\hline 910128 & 1000 & 1300 & - & - & 3 & 2.0 & - & $2 i$ \\
\hline 910129 & 1030 & 1500 & 1030 & 1500 & 4.5 & 1.6 & - & 19.5 \\
\hline 910130 & 1030 & 1530 & 1030 & 1530 & 5 & 1.6 & 260 & 19 \\
\hline 910131 & 1200 & 1730 & - & - & 5.5 & $1.2 / 2.2$ & - & 18.5 \\
\hline 910201 & 930 & 2100 & - & - & 13.5 & 2 & - & 10.5 \\
\hline 910202 & \multirow{2}{*}{\multicolumn{2}{|c|}{$\begin{array}{l}\text { LIMB unit off-line. } \\
\text { LIMB unit off-line. }\end{array}$}} & & & & & & 24 \\
\hline 910203 & & & & & & & & 24 \\
\hline 910204 & 1030 & 1800 & 1430 & 1800 & 7.5 & 2 & 260 & 16.5 \\
\hline 910206 & 1300 & 2400 & 1300 & 2400 & 11 & 2 & 260 & 13 \\
\hline 910206 & 0 & 2400 & 0 & 2400 & 24 & 2 & 260 & 0 \\
\hline 910207 & 0 & 2100 & 0 & 2100 & 21 & $1.2 / 1.6$ & 260 & 3 \\
\hline 910208 & \multicolumn{2}{|c|}{ LIMB unit off-lino. } & & & & & & 24 \\
\hline 910209 & \multirow{2}{*}{\multicolumn{2}{|c|}{$\begin{array}{l}\text { LIMB unit off-line. } \\
\text { LIMB unit off-line. }\end{array}$}} & & & & & & 24 \\
\hline 910210 & & & & & & & & 24 \\
\hline 910211 & 300 & 2400 & 1145 & 2400 & 21 & $0.8 / 2.2$ & 260 & 3 \\
\hline 910212 & 0 & 2400 & 0 & 2400 & 24 & 0.81 .0 & 260 & 0 \\
\hline 910213 & 0 & 2400 & 0 & 2400 & 24 & 2 & $145 / 260$ & 0 \\
\hline 910214 & 0 & 2400 & 0 & 2400 & 24 & 1.2 & 250 & 0 \\
\hline 910215 & 0 & 2400 & 0 & 2400 & 9 & 1.5 & 250 & 15 \\
\hline 910216 & 0 & 2400 & 0 & 2400 & 24 & 1.5 & 250 & 0 \\
\hline 910217 & 0 & 2400 & 0 & 2400 & 24 & 1.021 .5 & 250 & 0 \\
\hline 910218 & 0 & 2400 & 0 & 2400 & 24 & 1.75 & 250 & 0 \\
\hline 910219 & 0 & 2400 & 0 & 2400 & 24 & 1.05 & 250 & 0 \\
\hline 910220 & 0 & 2400 & 0 & 2400 & 24 & $1.2 / 1.5$ & 250 & 0 \\
\hline 910221 & 0 & 2400 & 0 & 2400 & 24 & $1.0 / 2.1$ & 240 & 0 \\
\hline 910222 & 0 & 2400 & 0 & 2400 & 24 & 1.5 & 250 & 0 \\
\hline 910223 & \multirow{2}{*}{\multicolumn{2}{|c|}{$\begin{array}{l}\text { LIMB unit off-inne. } \\
\text { LIMB unit off-lina. }\end{array}$}} & & & & & & 24 \\
\hline 910224 & & & & & & & & 24 \\
\hline 910225 & 1300 & 2400 & 1300 & 2400 & 11 & 1.5 & 275 & 13 \\
\hline 910226 & 0 & 1500 & 0 & 1600 & 10 & 2.2 & 275 & 14 \\
\hline 910227 & 1200 & 1500 & 1200 & 1500 & 3 & 2 & 275 & $? ?$ \\
\hline 910228 & 1100 & 2400 & 1100 & 2400 & 13 & 1.8 & 275 & 11 \\
\hline 910301 & 0 & 1330 & 0 & 1330 & 13.5 & 1.6 & 275 & 10.5 \\
\hline 910302 & \multirow{2}{*}{\multicolumn{2}{|c|}{$\begin{array}{l}\text { LIMB unit off-line. } \\
\text { LIMB unit off-line. }\end{array}$}} & & & & & & 24 \\
\hline 910303 & & & & & & & & 24 \\
\hline 910304 & 1030 & 1200 & 1030 & 1200 & 1.5 & 1.5 & 275 & 22.5 \\
\hline 910305 & 0 & 2400 & 0 & 2400 & 24 & 1.011 .5 & 275 & 0 \\
\hline 910306 & 0 & 1530 & 0 & 1530 & 15.5 & 1.3 & 275 & 8.5 \\
\hline 910307 & 1000 & 1700 & 1000 & 1700 & 7 & 1.021 .8 & 275 & 17 \\
\hline 910308 & 930 & 1400 & 930 & 1400 & 4.5 & 0.8 & 275 & 19.5 \\
\hline $\begin{array}{l}910309 \\
910310\end{array}$ & \multicolumn{2}{|c|}{$\begin{array}{l}\text { LIMB unit off-line. } \\
\text { LIMB unit off-line. }\end{array}$} & & & & & & $\begin{array}{l}24 \\
24\end{array}$ \\
\hline
\end{tabular}


TABLE 4-7. (CONTINUED)

\begin{tabular}{|c|c|c|c|c|c|c|c|c|}
\hline \multirow[t]{2}{*}{ ow } & \multicolumn{2}{|c|}{ mor } & \multicolumn{2}{|c|}{ 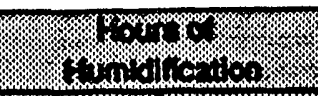 } & \multirow{2}{*}{ 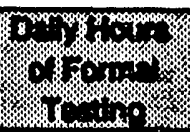 } & \multirow{2}{*}{ Ca/s. } & \multirow{2}{*}{ 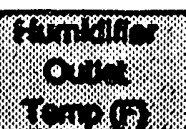 } & \multirow{2}{*}{ 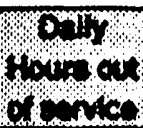 } \\
\hline & 10\% $\%$ & 40 & 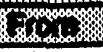 & X & & & & \\
\hline 910311 & 1000 & 2400 & 1000 & 2400 & 14 & 1.42 .0 & 273 & 10 \\
\hline 910312 & 0 & 2400 & 0 & 2400 & 24 & $1.2 / 1.4$ & 275 & 0 \\
\hline 910313 & 0 & 1500 & 0 & 1500 & 15 & 1.011 .2 & 275 & 9 \\
\hline 910314 & \multicolumn{2}{|c|}{ LIMB unit off-line. } & & & & & & 24 \\
\hline 910315 & \multirow{2}{*}{\multicolumn{2}{|c|}{$\begin{array}{l}\text { LIMB unit off-line. } \\
\text { LIMB unit off-line. }\end{array}$}} & & & & & & 24 \\
\hline 910316 & & & & & & & & 24 \\
\hline 910317 & \multicolumn{2}{|c|}{ LIMB unit off-line. } & & & & & & 24 \\
\hline 910318 & \multicolumn{2}{|c|}{ LIMB unit off-line. } & & & & & & 24 \\
\hline 910319 & \multirow{2}{*}{\multicolumn{2}{|c|}{$\begin{array}{l}\text { LIMB untt off-line. } \\
\text { LIMB unit off-line. }\end{array}$}} & & & & & & 24 \\
\hline 910320 & & & & & & & & 24 \\
\hline 910321 & \multicolumn{2}{|c|}{ LIMB unil off-line. } & & & & & & 24 \\
\hline 910322 & 1300 & 1600 & 1300 & 1600 & 3 & 1.6 & 275 & 21 \\
\hline 910323 & \multicolumn{2}{|c|}{ LIMB unit off-line. } & & & & & & 24 \\
\hline 910324 & \multicolumn{2}{|c|}{ LIMB unit off-lins. } & & & & & & 24 \\
\hline 910325 & \multicolumn{2}{|c|}{ LIMB unit off-IIne. } & & & & & & 24 \\
\hline 910326 & \multirow{2}{*}{\multicolumn{2}{|c|}{$\begin{array}{l}\text { LIMB unit off-ilna. } \\
\text { LIMB unit off-line. }\end{array}$}} & & & & & & 24 \\
\hline 910327 & LIMB & & & & & & & 24 \\
\hline 910328 & \multicolumn{2}{|c|}{ LIMB unit off-line. } & & & & & & 24 \\
\hline 910329 & \multicolumn{2}{|c|}{ LIMB unit off-inn. } & & & & & & $\begin{array}{l}24 \\
24\end{array}$ \\
\hline $\begin{array}{l}910010 \\
910331\end{array}$ & $\begin{array}{l}\text { LIMB } \\
\text { LIMB }\end{array}$ & $\begin{array}{l}t \text { oft-lina. } \\
\text { totf-line. }\end{array}$ & & & & & & 24 \\
\hline 9.10401 & 1300 & 1700 & 1300 & 1700 & 0 & 2.2 & 275 & 20 \\
\hline 910402 & 1000 & 1700 & 1000 & 1700 & 7 & 2.2 & 264 & 17 \\
\hline 910403 & 900 & 1700 & 900 & 1700 & 8 & 1.45 & 275 & 16 \\
\hline 910404 & 1500 & 2400 & 1500 & 2400 & 9 & 1.01 .85 & 275 & 15 \\
\hline 910405 & 0 & 1700 & 0 & 1700 & 17 & $1.0 / 2.0$ & 275 & 7 \\
\hline 910406 & LIMB & I oH-line. & & & & & & 24 \\
\hline 910407 & LIMB & toHt-line. & & & & & & 24 \\
\hline 91040,8 & LIMB & torf-lino. & & & & & & 24 \\
\hline 910409 & LIMB & I off-line. & & & & . & & 24 \\
\hline 910410 & LIMB & toff-line. & & & & & & 24 \\
\hline 910411 & 1000 & 2400 & 1000 & 2400 & 14 & 1.8 & 275 & 10 \\
\hline 910412 & 0 & 1800 & 0 & 1800 & 18 & 2 & 275 & 6 \\
\hline 910413 & LIMB & ioff-lino. & & & & & & 24 \\
\hline 910414 & LIME & toff-lline. & & & & & & 24 \\
\hline 910415 & 1100 & 2400 & 1100 & 2400 & 13 & 1.4 & 275 & 11 \\
\hline 910416 & 0 & 2400 & 0 & 2400 & 24 & 1.01 .8 & 275 & 0 \\
\hline 910417 & 0 & 2400 & 0 & 2400 & 24 & 2 & 275 & 0 \\
\hline 910418 & 0 & 2200 & 0 & 2200 & 22 & $1.0 / 1.8$ & 275 & 2 \\
\hline 910419 & LIMB & toff-llim. & & & & & & 24 \\
\hline 910420 & LIMB & $t$ off-line. & & & & & & 24 \\
\hline 910421 & LIMB & toff-line. & & & & & & 24 \\
\hline 910422 & 1100 & 2400 & 1100 & 2400 & 13 & $1.2 / 1.5$ & 275 & 11 \\
\hline 910423 & 0 & 2400 & 0 & 2400 & 24 & $0.8 / 1.65$ & 275 & 0 \\
\hline 910424 & 0 & 1600 & 0 & 1600 & 16 & 1.75 & $275 / 145 / 275$ & 8 \\
\hline 910425 & LIMB & toff-lino. & & & & & & 24 \\
\hline 910436 & LIMB & It off-lina. & & & & & & 24 \\
\hline 910427 & LIMB & th off-lino. & & & & & & 24 \\
\hline 910428 & LMB & th off-line. & & & & & & 24 \\
\hline 910420 & LME & HoH-line. & & & & & & 24 \\
\hline 910430 & LIMB & Hoff-llne. & & & & & & 24 \\
\hline
\end{tabular}




\subsection{AMBIENT MONITORING}

This section presents the results of ambient air dispersion modeling and groundwater monitoring. Section 5.1 discusses ambient air impacts predicted by using dispersion models with data from the November and December 1990, and January 1991 reporting period. Section 5.2 discusses ground-water monitoring.

\subsection{Ambient Air Dispersion Modeling}

Air dispersion modeling was conducted using EPA-approved models to assess ground level pollutant concentrations during sorbent injection periods. The air quality results presented in this section are based on emission and stack parameter data that are specific to the coal/sorbent combination utilized during a specific test period and the combination of combustion/control equipment used at this facility. Ambient air dispersion modeling was performed to determine site-specific air quality impacts. However, since the predicted impacts are dependent on site-specific factors, the results of air quality modeling conducted at another facility using this combustion and control technology would be expected to vary on a case-by-case basis. The site-specific parameters that would affect the modeling results are meteorological data, size of property (distance to nearest ambient air receptor), type of combustion and air pollution control equipment employed, operating conditions (including percent sulfur of coal and degree of pulverization), and stack parameter data.

Air dispersion modeling was conducted to assess ground level pollutant concentrations during seven injection periods. Table 5-1 shows the sorbent/coal combinations and dates used for each period. Modeling results show that the change in concentration (i.e., injection period maximum impacts minus Baseline maximum impacts) is less than $1.0 \mu \mathrm{g} / \mathrm{m}^{3}$ for $\mathrm{NO}_{\mathrm{x}}$ for all sorbent/coal injection periods modeled. Therefore, no further modeling of $\mathrm{NO}_{\mathrm{x}}$ was required. During the screening or initial modeling, results for $\mathrm{SO}_{2}$ indicated an increase in impacts over the Baseline values that were 
TABLE 5-1. INJECTION PERIODS MODELED FOR THE CURRENT REPORT

\begin{tabular}{||cl|}
\hline \multicolumn{1}{|c|}{ SORBENT/COAL COMBINATION } & INJECTION PERIOD \\
\hline DOLOMITIC LIME/NOMINAL 1.6 PERCENT SULFUR COAL & $(11 / 01 / 90 \cdot 11 / 12 / 90)$ \\
DOLOMITIC LIME/NOMINAL 3.0 PERCENT SULFUR COAL & $(11 / 13 / 90 \cdot 11 / 16 / 90)$ \\
DOLOMITIC LIME/NOMINAL 1.6 PERCENT SULFUR COAL & $(11 / 17 / 90 \cdot 11 / 27 / 90)$ \\
DOLOMITIC LIME/NOMINAL 3.8 PERCENT SULFUR COAL & $(11 / 28 / 90 \cdot 12 / 04 / 90)$ \\
DOLOMITIC LIME/NOMINAL 1.6 PERCENT SULFUR COAL & $(12 / 05 / 90 \cdot 12 / 21 / 90)$ \\
LIMESTONE/NOMINAL 1.6 PERCENT SULFUR COAL & $(12 / 22 / 90 \cdot 01 / 06 / 91)$ \\
LIMESTONE/NOMINAL 1.6 PERCENT SULFUR COAL & $(01 / 07 / 91 \cdot 01 / 23 / 91)$ \\
\hline
\end{tabular}


greater than the PSD significance criteria for the 3-hour, 24-hour and annual averaging periods. Therefore, additional modeling of $\mathrm{SO}_{2}$ impacts was required. As shown in this section, additional modeling demonstrated that the $\mathrm{SO}_{2} \mathrm{NAAQS}$ were not exceeded during any of the sorbent/coal injection periods.

The modeling methodology followed for this analysis and all other analyses was outlined in the report covering the period of October 1989 to January 1990. The fivepart methodology compares modeled ground level concentrations for the no sorbent injection (Baseline) case and modeled ground level concentrations during each of the coal/sorbent combinations to be evaluated. The ambient air modeling protocol is provided in Appendix $\mathrm{H}$.

\subsubsection{Air Quality Source Parameters}

To determine the combination of stack parameter and emission rate data that will predict the maximum air quality impacts, two data sets of representative stack parameters and emission rates were evaluated for each sorbent/coal injection period. In general, plume dispersion, and therefore, maximum predicted impacts are dependent on the stack parameters input to the model.

Therefore, prior to the ISCST modeling, two sets of data were evaluated, the maximum $\mathrm{SO}_{2}$ and $\mathrm{NO}_{x}$ emission rates with the maximum stack exit velocity for each injection period, and the mean $\mathrm{SO}_{2}$ and $\mathrm{NO}_{x}$ emission rates with the mean stack exit velocity for each sorbent/coal injection period. These two data sets were input to the EPA SCREEN dispersion model to determine the most conservative set of operating conditions for each injection period. Table 5-2 shows the scenario (i.e., maximum or average emission rate and exit velocity) and corresponding emission rate and exit velocity producing the largest impacts for each test period and pollutant. The maximum impacts are predicted to occur using the maximum emission rate and exit velocity for all cases 
except two dolomitic lime/nominal 1.6 percent sulfur coal test periods (11/01 to $11 / 12 / 90$, and $11 / 17$ to $11 / 27 / 90)$, for $\mathrm{SO}_{2}$.

The worst-case emission rates and exit velocities, which were input to the more refined ISCST dispersion model, were based on daily averages reported during each injection period. A representative exit temperature of $350^{\circ} \mathrm{K}$ was obtained from $\mathrm{B} \& \mathrm{~W}$ and input to the ISCST model. The total suspended particulates (TSP) and CO emission rates, and therefore, their ambient impacts, are assumed not to change substantially during any portion of the LIMB Demonstration Project Extension. As a result, no comparison is made for these pollutants between the sorbent/coal injection periods and the Baseline period.

\subsubsection{Air Quality Modeling Procedure}

The modeling was performed as outlined in the protocol discussed in the report covering the November 1989 to January 1990 period. A five-year analysis (1981-1985) was performed for each sorbent/coal injection period. The receptor grid used in the analysis, shown in Figure 5-1, is identical to the one described in previous reports. The 5 part analysis for the dolomitic lime/nominal 3.8 percent sulfur coal, worst-case model predicted impacts for $\mathrm{SO}_{2}$ that were greater than the NAAQS for the 3-hour and 24-hour averaging periods. Therefore, further refinement was included in the analysis of this injection period in order to better represent the actual ambient impacts that occurred.

Since the objective of the EMP is to assess the environmental impact due to the DOE LIMB Demonstration Project Extension, the refined analysis used representative meteorological data recorded at Cleveland-Hopkins and Buffalo International Airports from $11 / 27$ to $12 / 07 / 90$. The unprocessed data required for this analysis was obtained from the National Climatic Data Center and processed by Radian into the format necessary to run the ISCST model. The meteorological data consisted of hourly surface observations of wind speed and direction, temperature, ceiling height, cloud cover and 


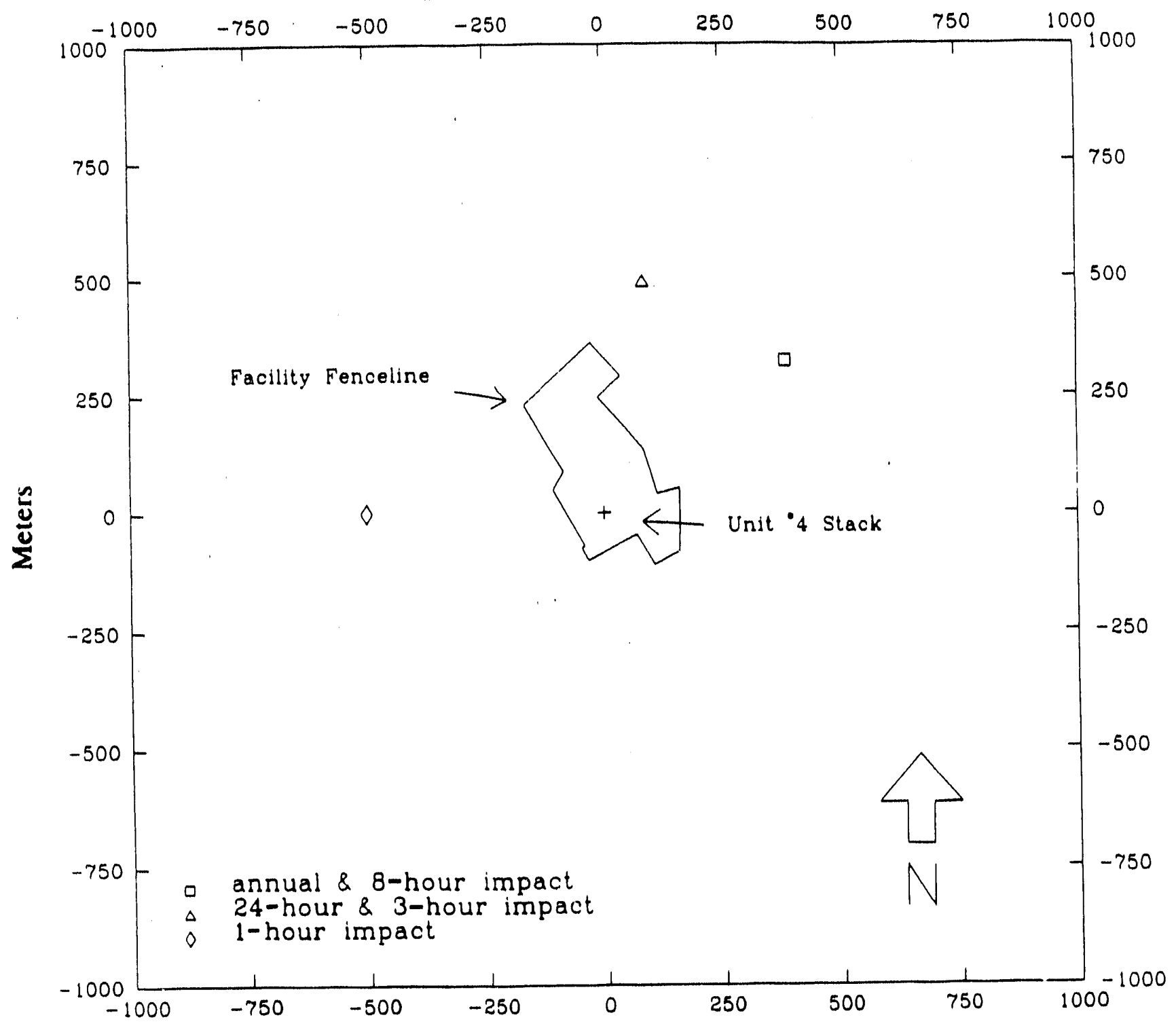

Meters

Figure 5-1. Modeled Impact Locations 
total opaque cloud cover, taken at Cleveland-Hopkins Airport. Mixing height data were derived from twice-daily radiosonde observations and hourly surface data recorded at Buffalo International Airport. The mixing heights were determined using the methodology outlined by Holzworth. ${ }^{1}$ Appendix I contains the hourly surface observations and the mixing height data input to the EPA PCRAMMET meteorological pre-processor program, which generates a file used by the ISCST model. Except for the use of real-time meteorological data, the refined modeling analysis conforms to the 5-part methodology described above.

\subsubsection{Air Quality Modeling Results}

The difference between the Baseline impacts and the impacts for each sorbent/coal injection period are shown in Table 5-3. Positive values indicate an increase in modeled impacts over Baseline impacts. The change in $\mathrm{NO}_{\mathrm{x}}$ concentrations varies only slightly between the seven injection periods, from $0.4 \mu \mathrm{g} / \mathrm{m}^{3}$ to $0.1 \mu \mathrm{g} / \mathrm{m}^{3}$. The change in $\mathrm{SO}_{2}$ concentrations is positive for all $\mathrm{SO}_{2}$ averaging periods for each sorbent/coal injection period except the dolomitic lime/nominal 1.6 percent sulfur coal injection period from $11 / 17$ to $11 / 27 / 90$.

As outlined in the report covering the period of October 1989 to January 1990, increases in predicted air quality impacts over Baseline conditions were compared to the ambient air significance levels as defined in the PSD air regulations. For $\mathrm{SO}_{2}$ and $\mathrm{NO}_{x}$, these values are $1.0 \mu \mathrm{g} / \mathrm{m}^{3}$ for the annual average, $5 \mu \mathrm{g} / \mathrm{m}^{3}$ for the 24-hour average, and $25 \mu \mathrm{g} / \mathrm{m}^{3}$ for the 3-hour average. For $\mathrm{NO}_{x}$, no increases exceeded $1.0 \mu \mathrm{g} / \mathrm{m}^{3}$ for the annual average, therefore, no further evaluation was necessary for this pollutant. For $\mathrm{SO}_{2}$, two averaging periods have increases less than their respective significance levels (dolomitic lime/nominal 1.6 percent sulfur coal and limestone/nominal 1.6 percent sulfur coal); therefore, these two periods require no further evaluation. 


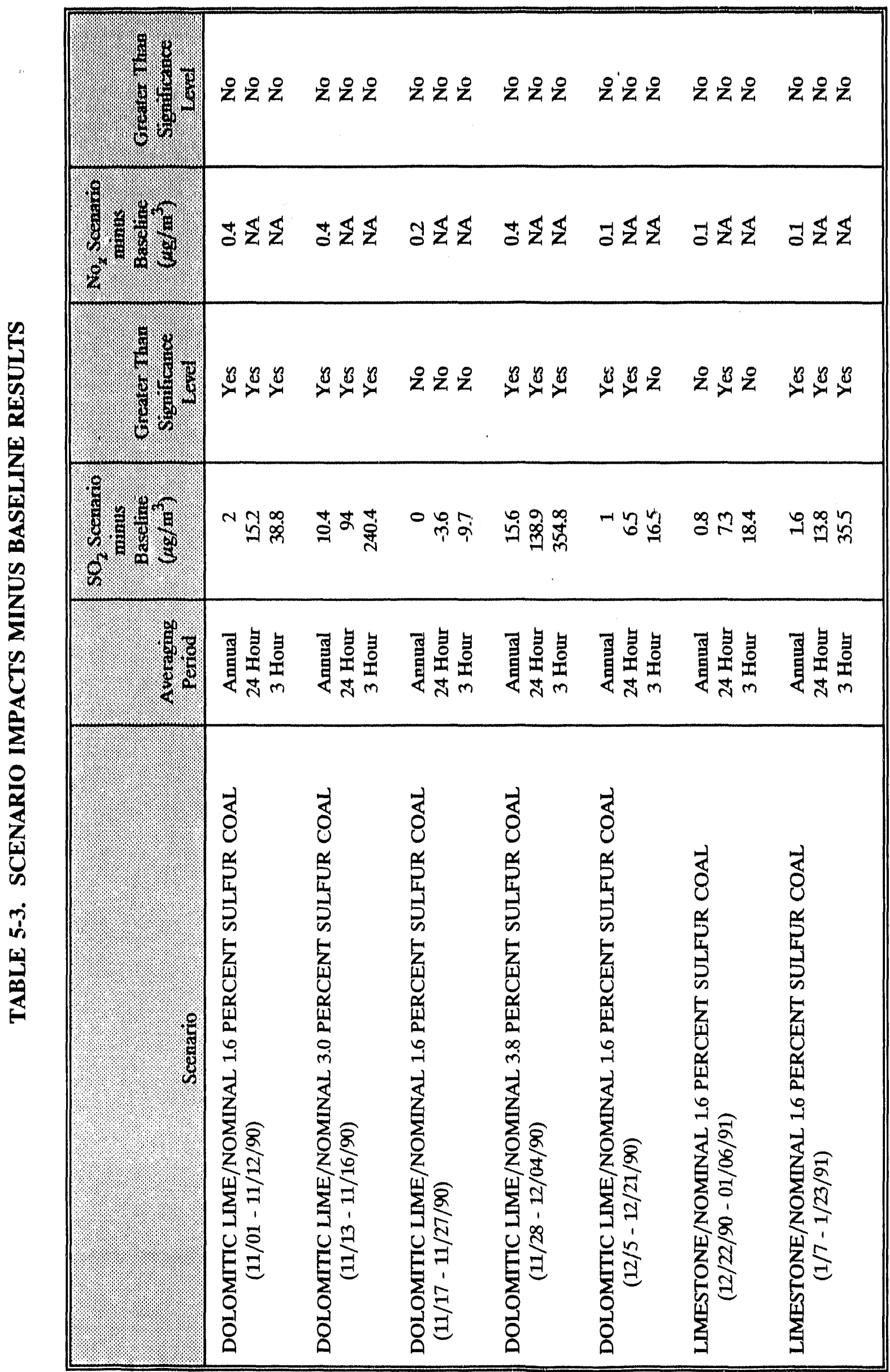


The October 1989 to January 1990 report presents a methodology to address situations when the difference between a test period impact and the Baseline impact is greater than PSD air significance levels. The methodology requires an evaluation of existing air monitoring data. Monitoring data were obtained from Ohio Environmental Protection Agency (OEPA) for two sites In Lorain, Ohio. The monitoring site best representing ambient background concentrations is located $6 \mathrm{~km}$ southeast of the Edgewater facility at 2270 East 42 nd Street. The 42nd Street monitoring site is close enough to be representative of background concentrations for the Lorain area while its location is such that the monitored values include only a small contribution from the Unit 4 stack. Two years (1986 and 1987) of monitoring data were avallable from the East 42nd Street monitor. Table 5-4 summarizes the monitoring data provided by the OEPA. The maximum annual value for the two years of data used is shown in this table. To determine background concentrations for an air quality analysis conducted using five years of meteorological data, the second highest monitored concentration is selected to determine compliance with the short term NAAQS (24-hour and 3-hour).

Table 5-5 presents the maximum predicted impacts (i.e., ISCST predicted impacts plus monitored values) for each of the injection periods and averaging periods with increases greater than PSD significance levels. The results show that a potential exceedance of the 24-hour $\mathrm{SO}_{2}$ NAAQS occurred during the dolomitic lime/3.8 percent sulfur coal combination. However, no other potential NAAQS exceedances are predicted for the injection periods modeled for this report.

As discussed in Section 5.1.2, a further refinement of the modeling analysis was performed in order to more accurately predict impacts during the dolomitic lime/ 3.8 percent sulfur coal injection period. Refined modeling shows that the 24-hour inupact (using representative meteorological data) is $19.0 \mu \mathrm{g} / \mathrm{m}^{3}$ lower than the Baseline concentration. Thus, as shown in Table 5-6, the use of representative meteorological data produces a model predicted impact which is less than the Baseline predicted impact. 
TABLE 5.4. AMBIENT AIR QUALITY MONITORING DATA

\begin{tabular}{|c|c|c|}
\hline Averaging Period & $\begin{array}{l}\mathrm{sO}_{2} \text { Ambient Monitored } \\
\text { Value }\left(\mu \mathrm{g} / \mathrm{m}^{3}\right)\end{array}$ & Monitored Year \\
\hline Annual & 23 & 1987 \\
\hline 24-Hour ${ }^{2}$ & 83 & 1986 \\
\hline 3-Hour ${ }^{2}$ & 411 & $f_{1986}$ \\
\hline
\end{tabular}

${ }^{1}$ Monitor location is 2270 East 42nd Street, Lorain, Ohio.

${ }^{2}$ Second-highest impacts from 1986 and 1987 data. 
TABLE 5-5. TOTAL SCENARIO $\mathrm{SO}_{2}$ IMPACTS

\begin{tabular}{|c|c|c|c|}
\hline Scenario & $\begin{array}{l}\text { Averaging } \\
\text { Perlod }\end{array}$ & $\begin{array}{c}\text { Scenario Impaot }{ }^{1}+ \\
\text { Monitored } \mathrm{SO}_{2} \text { Value } \\
\left(\mathrm{ug} / \mathrm{m}^{3}\right)\end{array}$ & $\begin{array}{l}\text { Percent of } \\
\text { NAAOS }\end{array}$ \\
\hline $\begin{array}{l}\text { DOLOMITTC LIME/NOMINAL 1,6 PERCENT SULFUR COAL } \\
(11 / 01 \cdot 11 / 12 / 90)\end{array}$ & $\begin{array}{l}\text { ANNUAL } \\
24 \text { HOUR } \\
3 \text { HOUR }\end{array}$ & $\begin{array}{r}42,9 \\
262 \\
867\end{array}$ & $\begin{array}{l}54 \% \\
72 \% \\
67 \%\end{array}$ \\
\hline $\begin{array}{l}\text { DOLOMITC LIME/NOMINAL 3,0 PERCENT SULFUR COAL } \\
(11 / 13-11 / 16 / 90)\end{array}$ & $\begin{array}{l}\text { ANNUAL } \\
24 \text { HOUR } \\
3 \text { HOUR }\end{array}$ & $\begin{array}{c}51,3 \\
341 \\
1070\end{array}$ & $\begin{array}{l}64 \% \\
93 \% \\
82 \%\end{array}$ \\
\hline $\begin{array}{l}\text { DOLOMITIC LIME/NOMINAL 1,6 PERCENT SULFUR COAL } \\
(11 / 17-11 / 27 / 90)\end{array}$ & $\begin{array}{r}\text { ANNUAL } \\
24 \text { HOUR } \\
3 \text { HOUR }\end{array}$ & $\begin{array}{l}N A \\
N A \\
N A\end{array}$ & $\begin{array}{l}\text { NA } \\
\text { NA } \\
\text { NA }\end{array}$ \\
\hline $\begin{array}{l}\text { DOLOMITTC LIME/NOMINAL 3,8 PERCENI' SULFUR COAL } \\
(11 / 28-12 / 04 / 90)\end{array}$ & $\begin{array}{r}\text { ANNUAL } \\
24 \text { HOUR } \\
3 \text { HOUR }\end{array}$ & $\begin{array}{c}56.5 \\
386 \\
1180\end{array}$ & $\begin{array}{r}71 \% \\
106 \% \\
91 \%\end{array}$ \\
\hline $\begin{array}{l}\text { DOLOMITIC LIME/NOMINAL } 1,6 \text { PERCENI' SULFUR COAL } \\
(12 / 5 \cdot 12 / 21 / 90)\end{array}$ & $\begin{array}{c}\text { ANNUAL } \\
24 \text { HOUR } \\
3 \text { HOUR }\end{array}$ & $\begin{array}{l}41.9 \\
253 \\
\text { NA }\end{array}$ & $\begin{array}{l}52 \% \\
61 \% \% \\
\text { NA }\end{array}$ \\
\hline $\begin{array}{l}\text { LIMESTONE/NOMINAL } 1.6 \text { PERCENT' SULFUR COAL } \\
(12 / 22 / 90-01 / 06 / 91)\end{array}$ & $\begin{array}{c}\text { ANNUAL } \\
24 \text { HOUR } \\
3 \text { HOUR }\end{array}$ & $\begin{array}{l}\text { NA } \\
254 \\
\text { NA }\end{array}$ & $\begin{array}{l}\mathrm{NA} \\
70 \% \\
\mathrm{NA}\end{array}$ \\
\hline $\begin{array}{l}\text { LIMESTONE/NOMINAL } 1,6 \text { PERCENT SULFUR COAL } \\
\left(1 / 7-\frac{1}{23 / 91)}\right.\end{array}$ & $\begin{array}{l}\text { ANNUAL } \\
\text { IA HOUR } \\
3 \text { HOUR }\end{array}$ & $\begin{array}{l}42.5 \\
261 \\
864\end{array}$ & $\begin{array}{l}12 \% \\
71 \% \\
66 \%\end{array}$ \\
\hline
\end{tabular}

124 -hour and 3 hour scenario impacts are second-highest impacts. 


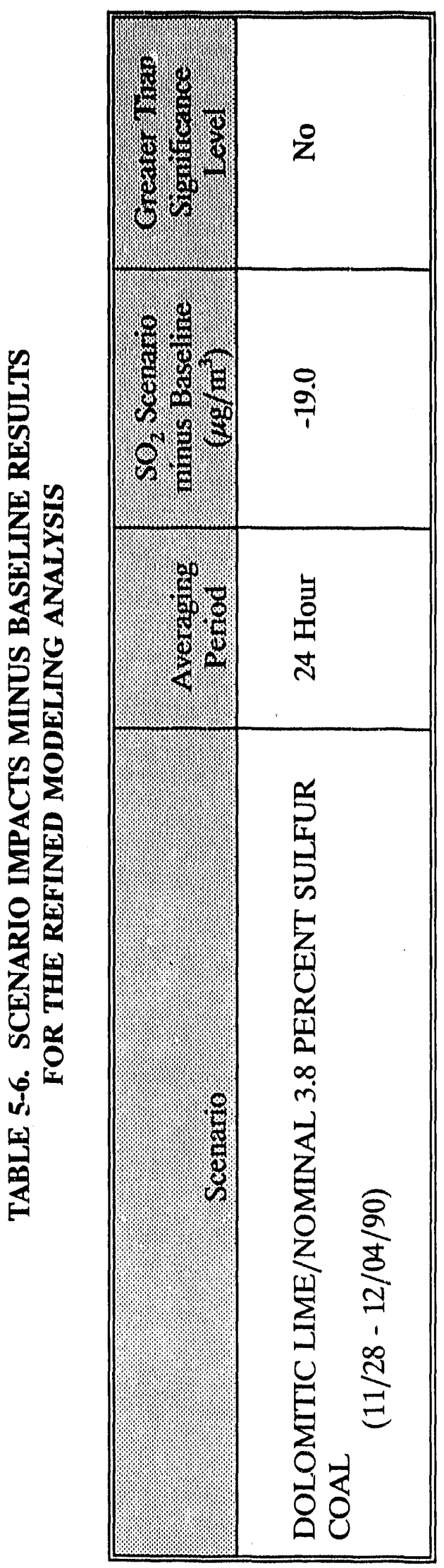


In summary, it should be emphasized that the intent of the EMP is to assess the environmental impact due to the DOE LIMB Demonstration Project Extension. The use of 5 years of meteorological data to determine the worst-case ambient impact during a 1 to 2 week test period is a very conservative methodology. However, the use of real-time meteorological data for each injection period is not always practical due to the difficulty of obtaining and processing the data in time for each report.

\subsection{Groundwater}

No further definition of the environmental impact of fly ash disposal at the Kimble Landfill or Ohio Edison Ash Disposal Facility was possible during this period, since no additional ground-water monitoring data were generated.

\subsection{References}

1. Holzworth, G. C., Mixing Heights, Wind Speed, and Potential For Urban Air Pollution Throughout Contiguous United States. U. S. Environmental Protection Agency, Research Triangle Park, North Carolina. January 1972. 


\subsection{HEAI,TH AND SAFETY}

All employee air and noise monitoring was completed in the previous reporting periods. No further employee exposure monitoring is planned for future reporting periods. 


\subsection{COMPLIANCE MONITORING STATUS}

Compliance monitoring is required for both gaseous and aqueous discharges. Opacity measurements, particulate emissions and $\mathrm{SO}_{2}$ emissions estimates are required to meet source permit operation requirements. Particulate emission measurements are required once every 3 years. Opacity measurements are monitored continuously, and $\mathrm{SO}_{2}$ emissions are to be estimated daily by using a coal sulfur content estimation method approved by the Ohio EPA. Table 7-1 presents the air compliance monitoring requirements for point sources at the facility. No compliance violations occurred for $\mathrm{SO}_{2}$, opacity, or particulate loading during the February, March and April 1991 reporting period.

Tables 4-2 and 4-3 provide wastewater compliance monitoring limitations and measured pollutant parameters. No NPDES permit values were exceeded in wastewater samples collected by Radian or Ohio Edison personnel during this reporting period. 


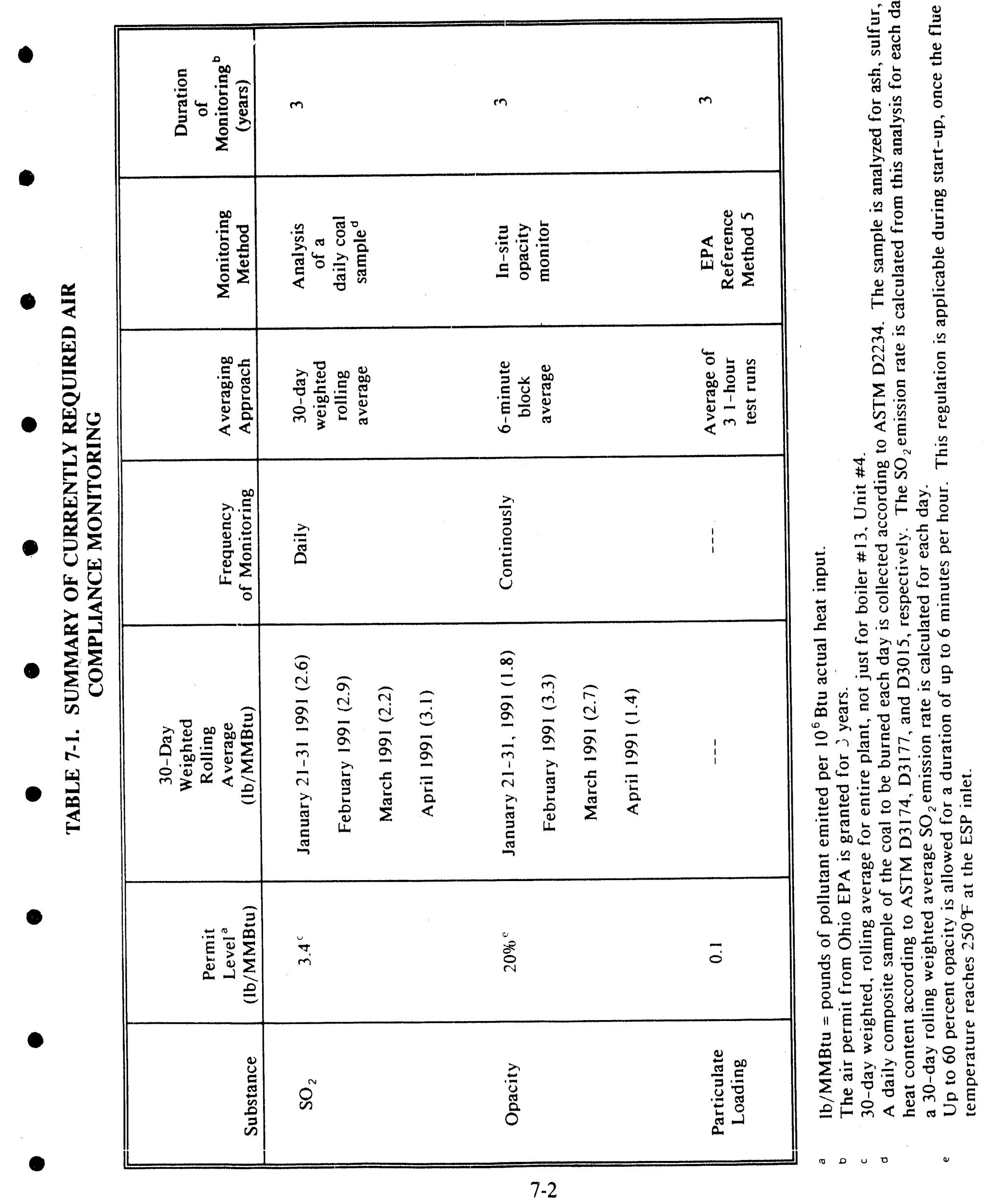




\subsection{QUALITY ASSURANCE/QUALITY CONTROL RESULTS}

All air quality monitoring data utilized in this report were collected by the DAS and are statistically summarized in Table 4-1 and in Appendix A. All sampling and analytical procedures, sample custody, calibration procedures, data reduction and validation, reporting procedures, internal quality control checks, performance and system audits, preventative maintenance, assessment of precision, accuracy and completeness, and corrective action are detailed in the LIMB Demonstration Extension Quality Assurance Project Plan, August 1990.

All NPDES water quality data for Outfall 601 utilized in Tables 4-2 and 4-3 and Appendix $B$ are collected by Ohio Edison as a part of its permit requirements. QA/QC data for the $\mathrm{pH}$, TSS, Flow, O\&G, Total $\mathrm{P}$, and As parameters are maintained by Ohio Edison personnel. 


\subsection{MONITORING PROBLEMS AND RECOMMENDATIONS FOR CHANGE}

No monitoring equipment problems were encountered during the February, March and April 1991 reporting period. The data provided by the System 140 was extensively reviewed this reporting period to correct for highly repetitive data and erroneously high $\mathrm{SO}_{2}$ and $\mathrm{NO}_{x}$ values (lb/MMBtu). The highly repetitive data points were identified when the boiler was taken off-line (a period of minimal heat production). The System 140 would lock on to the last value while the system was placed off-line and repeat this value until the boiler and System were placed back on-line. In addition, erroneously high $\mathrm{SO}_{2}$ and $\mathrm{NO}_{x}$ concentration values were recorded when CEM equipment would automatically blow down to clear the intake lines. Both the repetitive and erroneously high values were removed from the data used to calculate the daily averages.

A wastewater monitoring equipment problem was encountered during this reporting period. The probe used by Radian personnel to monitor wastewater $\mathrm{pH}$ broke on March 17, 1991 and was replaced on March 22, 1991. 


\section{APPENDIX A \\ DETAILED DAILY AVERAGE AIR EMISSIONS}

3

3

$\boldsymbol{9}$ 
DETAILED DAILY AVERAGE AIR EMISSIONS DATA

\begin{tabular}{|c|c|c|c|c|c|c|c|c|c|}
\hline \multirow{2}{*}{ Doto } & \multirow{2}{*}{ 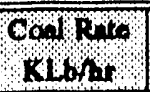 } & \multirow{2}{*}{ H 140} & \multirow{2}{*}{198} & \multirow{2}{*}{$0 \%$} & \multicolumn{2}{|c|}{69011} & \multirow{2}{*}{$48 \% 9 \%$} & \multicolumn{2}{|c|}{ 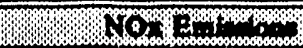 } \\
\hline & & & & & 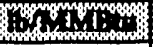 & $40 x$ & & onow & or. (S) \\
\hline 910201 & 69 & 12137 & 1.54 & 1.18 & 2.21 & 1845.62 & 23.54 & 0.40 & 334.76 \\
\hline 910204 & 37 & 12509 & 1.67 & 0.14 & 2.08 & 960.70 & 30.64 & 0.36 & 166.03 \\
\hline 910205 & 54 & 12524 & 2.08 & 0.05 & 2.53 & 1713.46 & 31.21 & 0.45 & 307.24 \\
\hline 910206 & 62 & 12442 & 2.42 & 0.26 & 3.49 & 2694.48 & 22.75 & 0.45 & 346.56 \\
\hline 910207 & 73 & 12526 & 2.92 & 3,26 & 3.75 & 3432.97 & 30.81 & 0.47 & 433.95 \\
\hline 910214 & 48 & 12308 & 3.06 & 5.60 & 3.70 & 2191.41 & 34.26 & 0.45 & 267.11 \\
\hline 910215 & 51 & 12073 & 2.95 & 6.52 & 4.32 & 2636.81 & 21.34 & 0.39 & 238.79 \\
\hline 910216 & 40 & 12113 & 2.95 & 5,40 & 4.19 & 1996,95 & 21.45 & 0.42 & 199.59 \\
\hline 910217 & 40 & 12356 & 2.97 & 5,44 & 4.35 & 2148.15 & 21.63 & 0.42 & 207.24 \\
\hline 910218 & 39 & 12342 & 2.88 & 5.25 & 3.53 & 1682.14 & 21.17 & 0.41 & 193.87 \\
\hline 910221 & 44 & 12427 & 3.02 & 2.56 & 3.31 & 1791.23 & 46.38 & 0.44 & 238.34 \\
\hline 910222 & 47 & 12429 & 2.25 & 3.09 & 1.71 & 994.91 & 73.10 & 0.44 & 255.19 \\
\hline 910226 & 54 & 12353 & 1.47 & 3.31 & 1.86 & 1233.11 & 30.62 & 0.38 & 249.20 \\
\hline 910227 & 56 & 12526 & 1.28 & 3.13 & 1.89 & 1318.57 & 15.44 & 0.40 & 281.76 \\
\hline 910228 & 54 & 12073 & 1.15 & 2.77 & 1.59 & 1036.84 & 23.30 & 0.39 & 251.39 \\
\hline Average & 51 & 12343 & 2.31 & 3.20 & 2.97 & 1845.16 & 29.84 & 0.42 & 264.73 \\
\hline Maximum & 73 & 12526 & 3.06 & 6.52 & 4.35 & 3432.97 & 73.10 & 0.47 & 433.95 \\
\hline Minimum & 37 & 12073 & 1.15 & 0.05 & 1.59 & 960.70 & 15.44 & 0.36 & 166.03 \\
\hline 910301 & 47 & 12555 & 1.07 & 2.42 & 1.50 & 876.59 & 23.44 & 0.35 & 207.21 \\
\hline 910304 & 59 & 12356 & 1.19 & 3.70 & 1.92 & 1397.54 & 21.32 & 0.34 & 244.67 \\
\hline 910305 & 59 & 12130 & 1.22 & 2.50 & 1.80 & 1286.11 & 22.94 & 0.37 & 263.81 \\
\hline 910306 & 51 & 12328 & 1.21 & 2.40 & 1.99 & 1260.73 & 23.24 & 0.38 & 239.40 \\
\hline 910307 & 61 & 12425 & 1.28 & 2.67 & 2.19 & 1668.45 & 29.20 & 0.40 & 304.33 \\
\hline 910308 & 53 & 12580 & 1.47 & 2.77 & 2.67 & 1770.19 & 9.36 & 0.36 & 239.99 \\
\hline 910311 & 50 & 12482 & 1.49 & 2.49 & 2.24 & 1396.43 & 19.69 & 0.38 & 239.63 \\
\hline 910312 & 56 & 12334 & 1.47 & 2.80 & 2.11 & 1468.07 & 22.85 & 0.37 & 258.24 \\
\hline 910313 & 52 & 12263 & 1.41 & 2.99 & 2.08 & 1330.89 & 29.12 & 0.37 & 234.55 \\
\hline 910314 & 57 & 12490 & 1.36 & 2.74 & 2.59 & 1830.81 & 11.25 & 0.30 & 211.64 \\
\hline 910315 & 43 & 12304 & 1.36 & 2.74 & 2.56 & 1356.16 & 23.58 & 0.30 & 159.92 \\
\hline 910322 & 47 & 12341 & 1.59 & 2.00 & 2.58 & 1498.94 & 21.46 & 0.36 & 209.65 \\
\hline Average & 53 & 12382 & 1.34 & 2.68 & 2.19 & 1428.41 & 21.45 & 0.36 & 234.42 \\
\hline Maximum & 61 & 12580 & 1.59 & 3.70 & 2.67 & 1830.81 & 29.20 & 0.40 & 304.33 \\
\hline Minimum & 43 & 12130 & 1.07 & 2.00 & 1.50 & 876.59 & 9.36 & 0.30 & 159.92 \\
\hline
\end{tabular}


DETAILED DAILY AVERAGE AIR EMISSIONS DATA

\begin{tabular}{|c|c|c|c|c|c|c|c|c|c|}
\hline \multirow[t]{2}{*}{ port } & \multirow{2}{*}{$\mathrm{Com}_{\mathrm{N}}$} & \multirow{2}{*}{ aro 18} & \multirow{2}{*}{1680} & \multirow{2}{*}{$8 \%$} & \multicolumn{2}{|c|}{ SO2 Ormpen } & \multirow{2}{*}{ 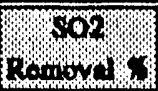 } & \multicolumn{2}{|c|}{ NQA EDf wOW } \\
\hline & & & & & 16 NuM & bot +2$)$ & & WONABA & bont (2) \\
\hline 910401 & 41 & 12428 & 1.85 & 1.91 & 2.58 & 1300,59 & 22.56 & 0.36 & 181.28 \\
\hline 910402 & 60 & 12620 & 1.59 & 1.62 & 2.46 & 1863,90 & 28.51 & 0.35 & 269.23 \\
\hline 910403 & 66 & 12489 & 1.59 & 1.32 & 2.65 & 2187.32 & 35.25 & 0.38 & 311.15 \\
\hline 910404 & 67 & 12592 & 1.61 & 0.85 & 2.57 & 2160.90 & 21.78 & 0.39 & 327.88 \\
\hline 910405 & 52 & 12966 & 1.55 & 0.37 & 2,09 & 1408.27 & 25.67 & 0.40 & 268.02 \\
\hline 910411 & 38 & 12342 & 2.46 & 2.84 & 3.17 & 1494,40 & 55.54 & 0.38 & 177.96 \\
\hline 910412 & 50 & 12214 & 2.66 & 2.90 & 2.99 & 1826.55 & 37.71 & 0.42 & 253.96 \\
\hline 910415 & 53 & 12234 & 2.58 & 2.66 & 3.15 & 2058.07 & 39.26 & 0.40 & 262.94 \\
\hline 910416 & 46 & 12265 & 2.57 & 1.85 & 2.91 & 1653,09 & 36,36 & 0.40 & 225.05 \\
\hline 910417 & 55 & 12075 & 2.92 & 1.11 & 3.42 & 2256.01 & 38.62 & 0.41 & 269.16 \\
\hline 910418 & 70 & 12083 & 3.33 & 0.57 & 3.70 & 3123.06 & 41.54 & 0.43 & 363.96 \\
\hline 910422 & 67 & 12222 & 3.58 & 1.04 & 3.56 & 2896.39 & 43.94 & 0.43 & 347.26 \\
\hline 910423 & 52 & 12447 & 3.41 & 0.49 & 4,12 & $2661,9^{\prime} 7$ & 33.40 & 0.42 & 273.33 \\
\hline 910424 & 40 & 12535 & 3.43 & 0.44 & 3.61 & 1792.30 & 41.21 & 0.41 & 202.41 \\
\hline Average & 54 & 12394 & 2.51 & 1.43 & 3.07 & 2048.77 & 35.81 & 0.40 & 266.69 \\
\hline Maximum & 70 & 12966 & 3.58 & 2.90 & 4.12 & 3123.06 & 55.54 & 0.43 & 363.96 \\
\hline Minimum & 38 & 12075 & 1.55 & 0.37 & 2.09 & 1300.59 & 21.78 & 0.35 & 177.96 \\
\hline \multicolumn{10}{|c|}{ LIMB Estension: } \\
\hline 1001 & 56 & 1038 & 201 & 130 & 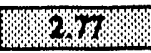 & $1 \% 2 \%$ & $2 \% 3$ & 040 & 27567 \\
\hline \multicolumn{10}{|c|}{ Baseline Period: February 17, 1990 through April 23, 1990} \\
\hline Avons. & S8 & 1600 & Wh & (50 & 10 & 83200 & W1 & $0 \%$ & 18100 \\
\hline
\end{tabular}

1. HHV = Higher Heating Value

2. These values calculated as: $\mathrm{lbs} / \mathrm{hr}=((\mathrm{lbs} / \mathrm{mmBtu})(\mathrm{Klb} / \mathrm{hr}) *(\mathrm{Btu} / \mathrm{lb})(1000 \mathrm{lb} / \mathrm{Klb}) /(10 \mathrm{E} 6 \mathrm{Btu} / \mathrm{mmBtu}))$ 


\section{APPENDIX $\mathrm{B}$}

G01 OUTFALL COMPLIANCE REPORTS 
1510 Y 8000850826

I mur moem rown

losero sorson conenrs

i toomarse runit

16 SOUTH MAIN STREETS

AKRON, Ot 44308 LORATH
ENV A SPEC PROS

1600

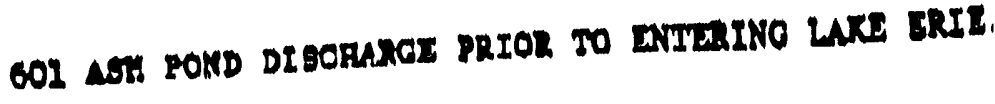

mons

8. AILL.

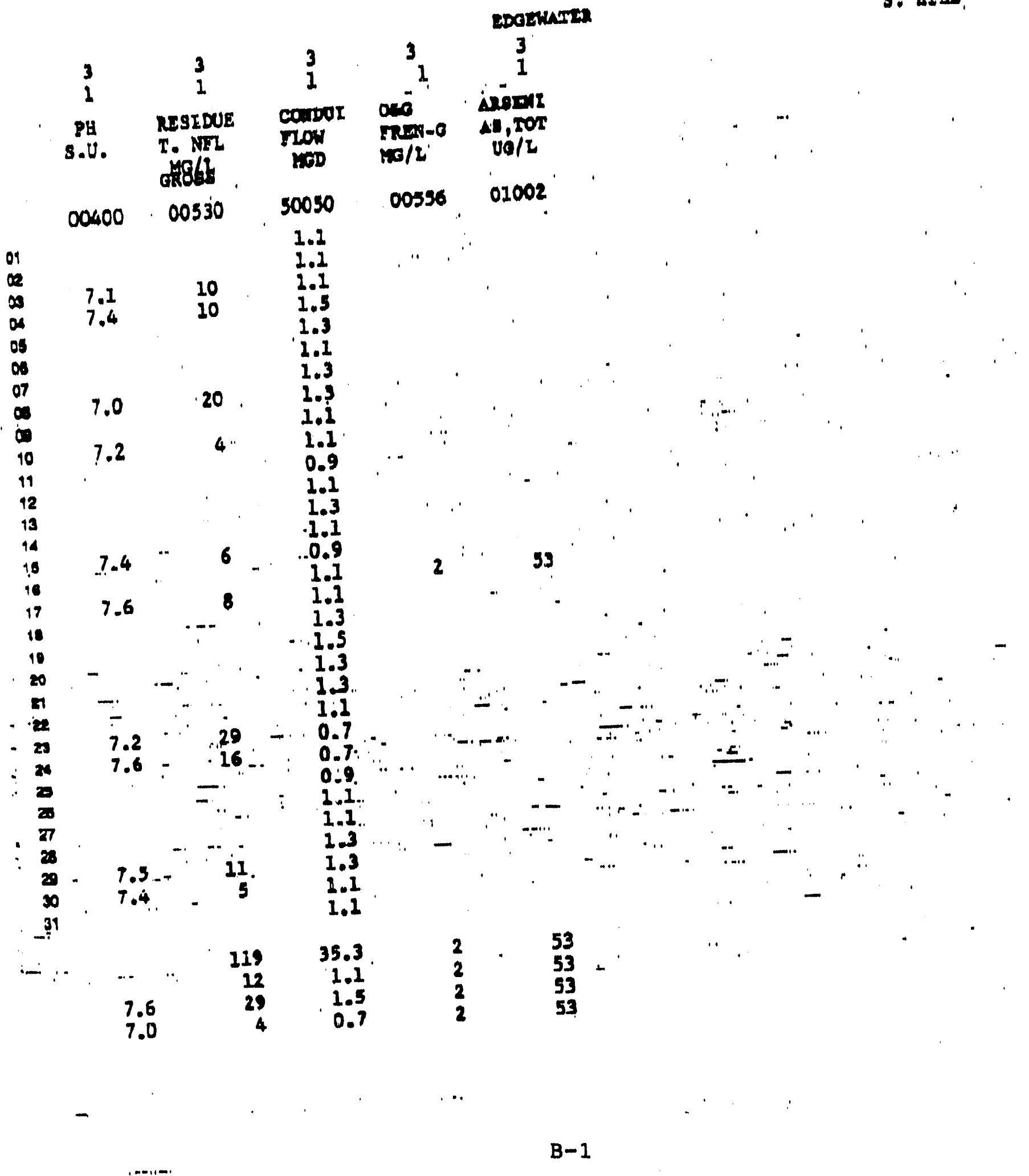


IY RLFOWT rom

HIO IDISON COMPANY

CDGEWATER PLANT

76 SOUTH MAIN STREET

AKRON, OH 44308 LORAIN
4800

31800005601
FEB-91

11

$3-5-91$

diver

601 ASH POND DISCHARGE PRIOR TO ENTERING LAKE ERIE

FOAM

S. HILL

\begin{tabular}{|c|c|c|c|}
\hline 3 & 3 & 3 & 3 \\
\hline 1 & 1 & 1 & 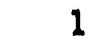 \\
\hline & RESTDUE & CONDUI & O\&G \\
\hline $\mathrm{PH}$ & $M G / L$ & FLOW & FREN \\
\hline S.U. & GROSS & MGD & $M G / L$ \\
\hline 00400 & 00530 & 50050 & 0055 \\
\hline & & $\begin{array}{l}1.3 \\
1.3\end{array}$ & \\
\hline & & 1.3 & \\
\hline 7.4 & 4 & 1.3 & \\
\hline & & 1.2 & \\
\hline & & 1.2 & \\
\hline 7.6 & 3 & 0.9 & \\
\hline & & 1.1 & \\
\hline & & 1.1 & \\
\hline & & 0.9 & \\
\hline & & 0.9 & \\
\hline & & 1.1 & \\
\hline 7.5 & 7 & 0.9 & 1 \\
\hline & & 0.9 & \\
\hline 7.5 & $B$ & 0.7 & \\
\hline & & 0.7 & \\
\hline & & 0.9 & \\
\hline & & 1.1 & \\
\hline & & 1.1 & \\
\hline & & 1.1 & \\
\hline 8.5 & 6 & 1.1 & \\
\hline 8.2 & 8 & 1.1 & \\
\hline & & 0.9 & \\
\hline & & 0.9 & \\
\hline & & 1.1 & \\
\hline 7.1 & 16 & 1.1 & \\
\hline & & 1.1 & \\
\hline & & & \\
\hline & 52 & 29.4 & 1 \\
\hline & 7 & 1.1 & 1 \\
\hline 8.5 & 16 & 1.3 & 1 \\
\hline 7.1 & 3 & 0.7 & 1 \\
\hline
\end{tabular}

DDEWATER

3

\&G

REN-G

G/L AS

00556

25


HLY AEPOAT FOAM

4500

"OHIO EDISON COMPANY

$3 I B 00005601$

MAR-91

12

OHOOS1306

EDGEWATER PLAN'T

76 SOUTH MAIN STREET

AKRON

44308 LORAIN

601 ASH POND DISCHARGE PRIOR TO ENTERING LAKE ERIE

FORM

EDGEWATER

\begin{tabular}{cc}
3 & 3 \\
1 & 1 \\
\hline$H$ & RESIDU
\end{tabular}

PH RESIDU

S.U.

T. NFL

MG/L

GROSS

$00400 \quad 00530$

7.5

00530

3

13

CONDUI

FLOW

MGD

50050

1.1

1.1

1.7

1.6

wat
$8.0+8.2^{2}$

x|l

$8.0+8 \cdot 210$

7.5

16

7.4

7.4

14

2.1

2.6

2.1

1.6

1.6

1.6

1.3

1.3

1.4

1.6

1.4

1.7

1.1

1.1

1.1

7.4

6

0.8

7.6

24

7.6

7.7

4

5

1.3

1.8

1.7

0.9

1.1

1.6

0.9

1.6

1.6

1.6

0.9
AA

43

33
0.005

$$
3
$$

3
1

CYANID

FREE

MG/L

00719

$00556 \quad 00978$

AA

AA

0.1

0.3

S. HILL

$\begin{array}{cc}3 & 3 \\ 1 & 1 \\ \text { CAD } & \text { CHROM } \\ \text { CD, TOT } & \text { HEX-VA } \\ \text { UG/L } & \text { UG/L }\end{array}$

01027

0103

01012

01027

$G / L$ 
MHLY MEPOAT PONM

JHIO EDISON COMPANY

EDGEWATER PLANT

76 SOUTH MAIN STREET

AKRON 44308 LORAIN
4500
$31 \mathrm{~B} 00005601$
$A P R-91$
11
OHOOS13C

601

ASH POND DISCHARGE PRIOR TO ENTERING LAKE ERIE

FORM

EDGEWATER

S. HILL

\begin{tabular}{|c|c|c|c|}
\hline $\begin{array}{l}3 \\
1\end{array}$ & 3 & 3 & $\begin{array}{l}3 \\
1\end{array}$ \\
\hline PH & RESIDU & CONDUI & O\&G \\
\hline S.U. & $\begin{array}{l}\text { T. NFL } \\
\text { MG/L } \\
\text { GROSS }\end{array}$ & $\begin{array}{l}\text { FLOW } \\
\text { MGD }\end{array}$ & $\begin{array}{l}\text { FREN-G } \\
M G / L\end{array}$ \\
\hline 00400 & 00530 & 50050 & 00556 \\
\hline 7.3 & 41 & $\begin{array}{l}1.6 \\
1.6\end{array}$ & \\
\hline & & 1.6 & $A A$ \\
\hline 7.3 & 6 & $\begin{array}{l}1.6 \\
1.4 \\
1.3 \\
1.3\end{array}$ & \\
\hline 7.7 & 2 & $\begin{array}{l}0.7 \\
0.7 \\
1.1\end{array}$ & \\
\hline 7.5 & 7 & $\begin{array}{l}1.1 \\
1.1 \\
1.3 \\
1.1 \\
1.1\end{array}$ & \\
\hline 8.1 & 24 & $\begin{array}{l}1.4 \\
1.3\end{array}$ & \\
\hline 7.8 & 4 & $\begin{array}{l}1.3 \\
1.3 \\
1.5 \\
1.5 \\
1.5\end{array}$ & \\
\hline 7.3 & 14 & 1.5 & \\
\hline 7.4 & 6 & $\begin{array}{l}1.3 \\
1.3 \\
1.1 \\
0.7 \\
0.7 \\
0.7\end{array}$ & \\
\hline 7.0 & 11 & 0.7 & \\
\hline
\end{tabular}

$\begin{array}{rrrr} & 115 & 32.6 & \text { AA } \\ & 13 & 1.1 & \text { AA } \\ 8.1 & 41 & 1.6 & \text { AA } \\ 7.0 & 2 & 0.7 & \text { AA }\end{array}$

AA: Below Detectable Limits 


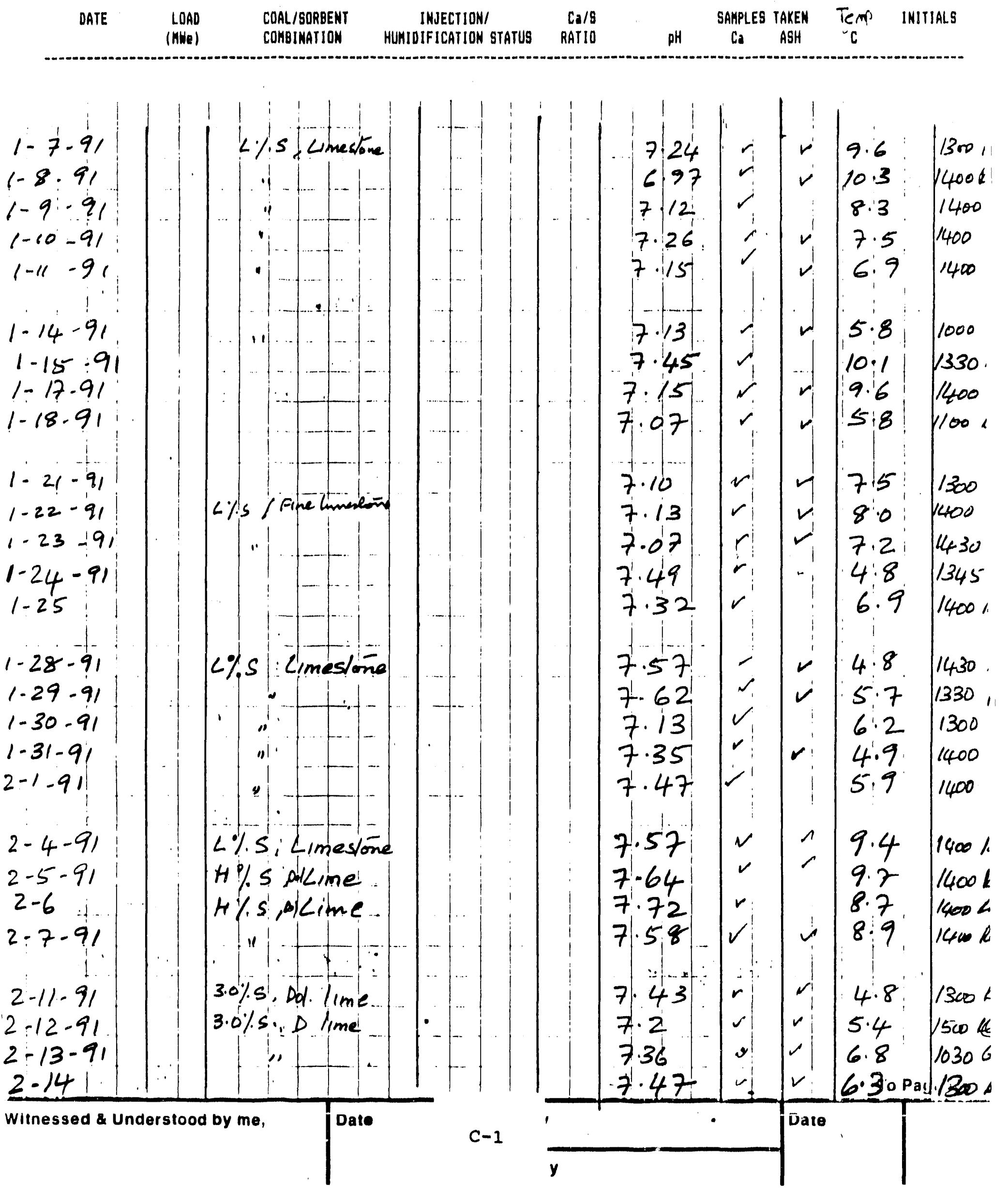




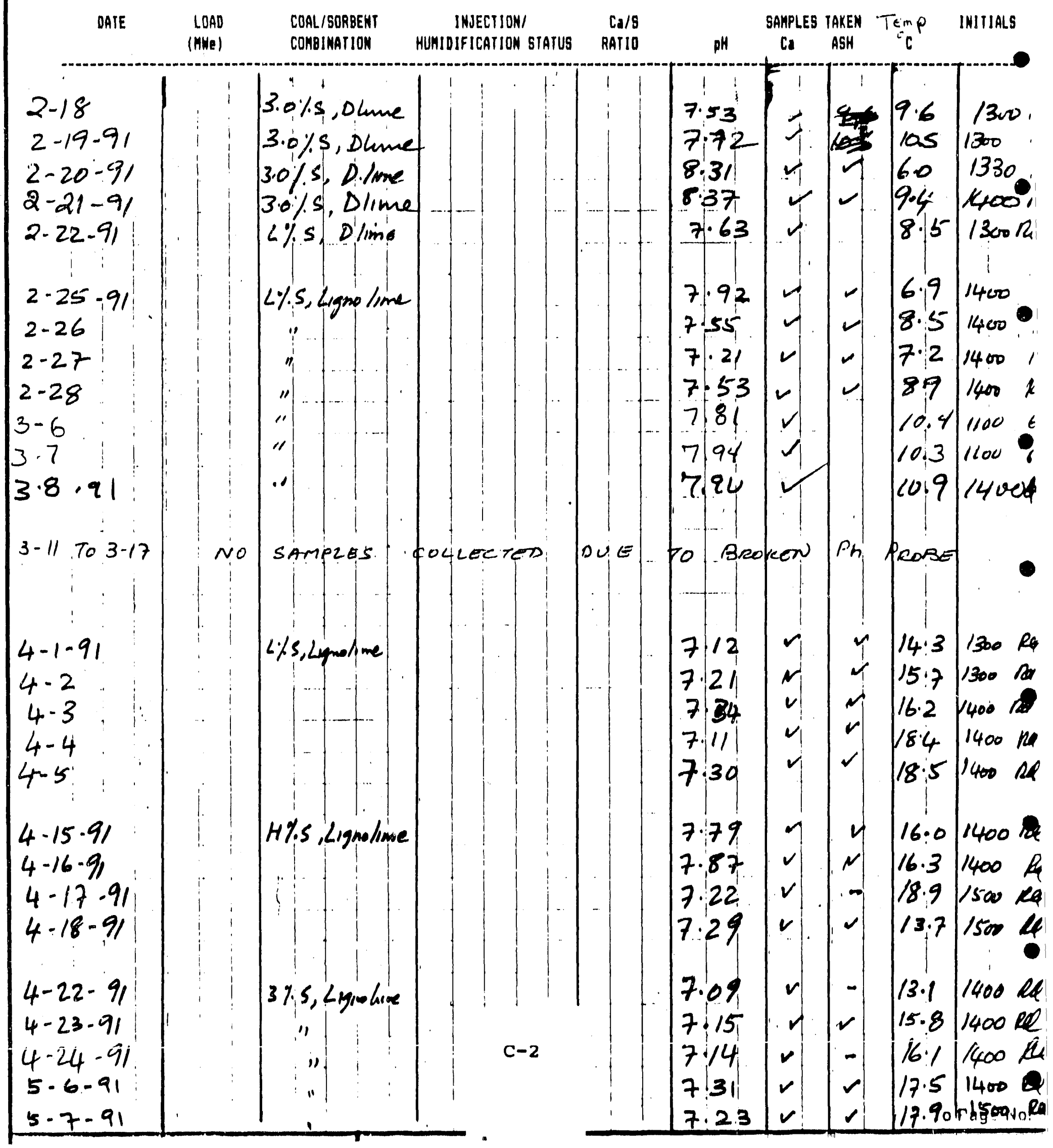


Analytical Report

03/26/91

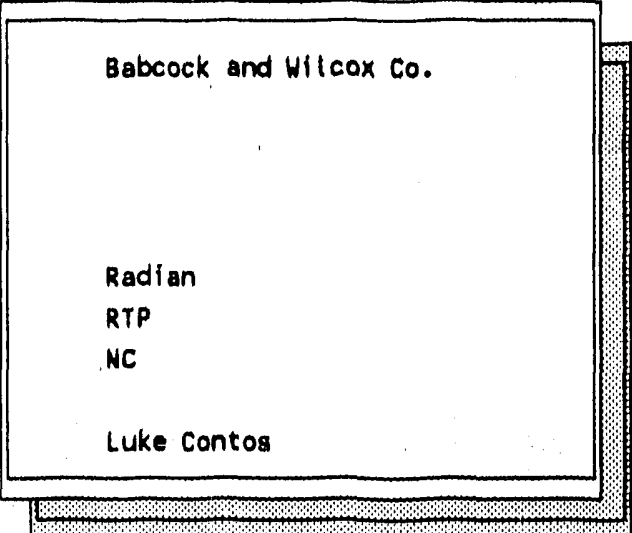

Customer Work Identification LIMB PROJECT

Purchase Order Number 209-026-05-00

Contents:

Analytical Data Summary

Sample History

Corments Summery

Notes and Definitions

Radian Analytical Services

8501 Mo-Pac Boulevard

P. O. Box 201088

Aust in, TX 78720-1088

$512,1454-4797$

Client Services Coordinator: KAYOUNG

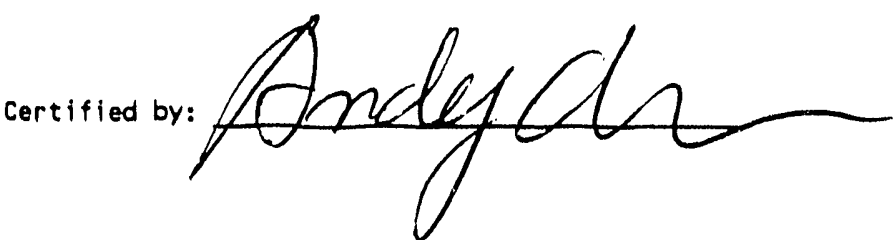


abcock and Wilcox Co.

Radian Work Order: 91-03-010

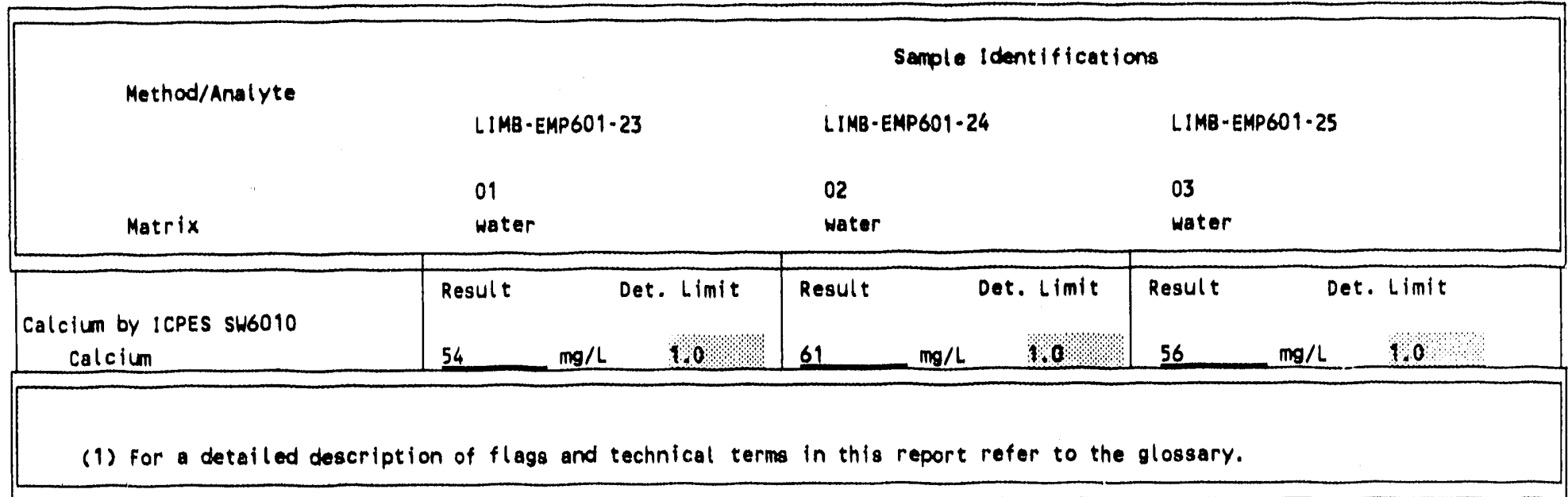


Babcock and Wilcox Co.

Radian Work Order; 94.03.010

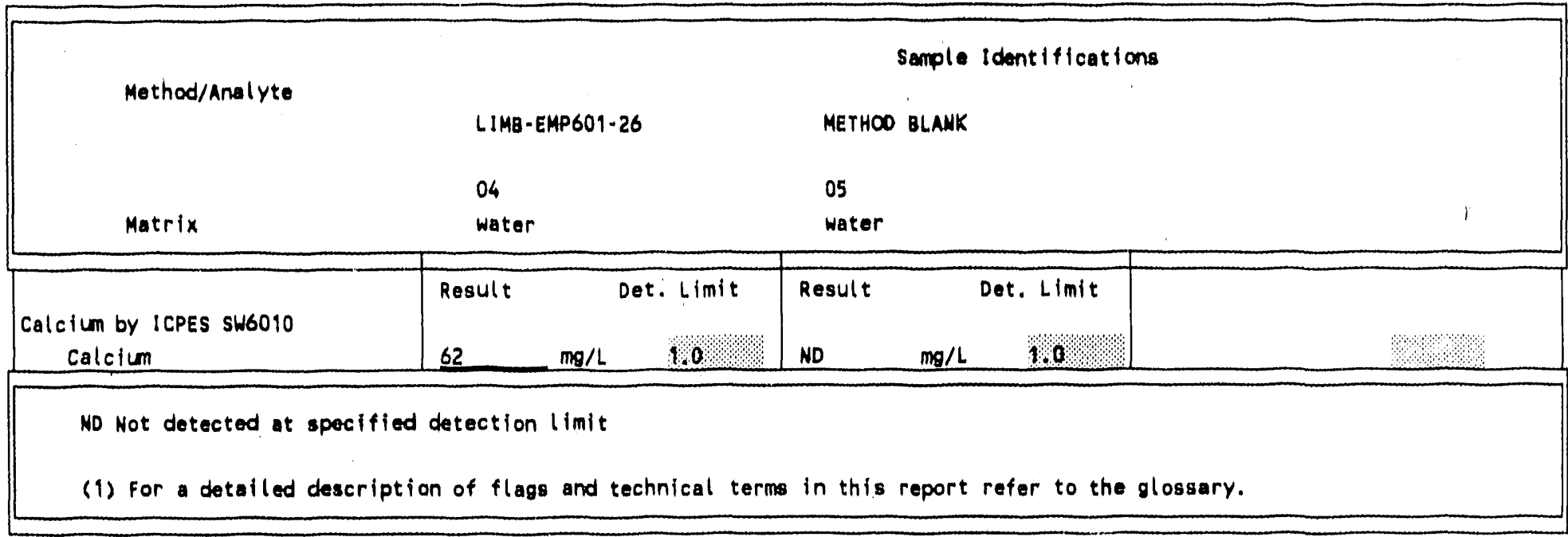


Babcock and Wilcox co.

Radian Work Order: 91.03-010

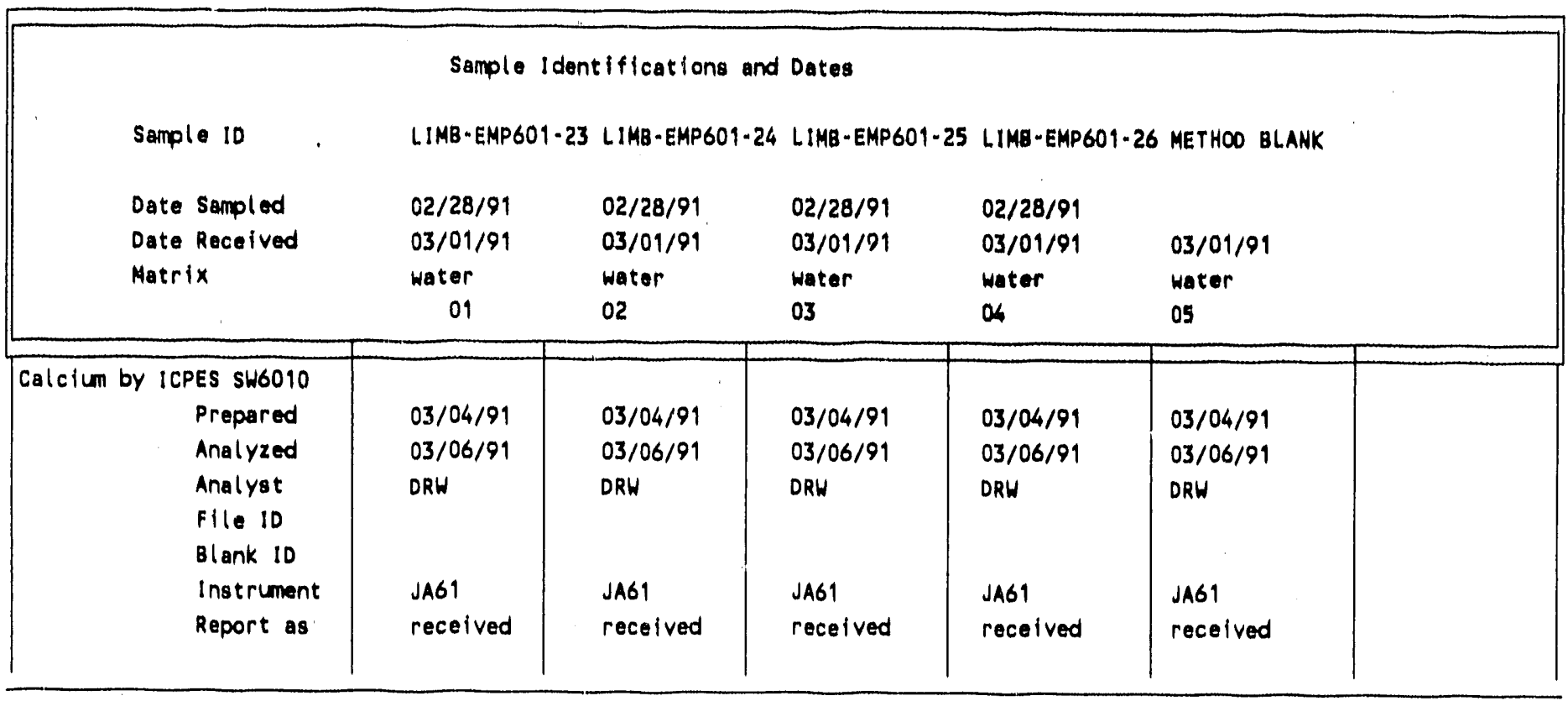




\section{RADIAN}

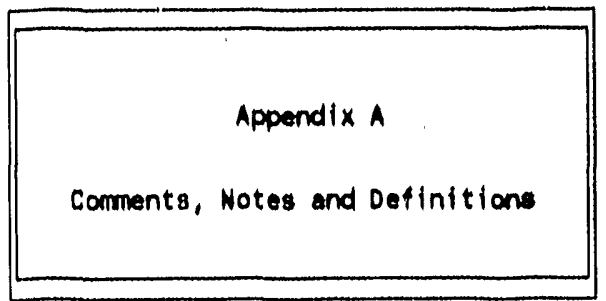

$D-5$ 
Babcock and Wilcox co.

Radian Work Orders $99.03-010$

ND ALL METHOOS EXCEPT CLP

This flag is used to denote analytes which are not detected at or above the speciffed detection $\mid / \mathrm{m} / \mathrm{t}$.

EXPLANATION

The value to the right of the s symbol is the method specifled

detection limit for the analyte. 
Babcock and Wilcox Co. Radian Work Order: 91.03 .010

TERMS USED IN THIS REPORTI

Analyte. A chemical for which a sample is to be analyzed. The analysis will meat EPA method and OC speciffications.

Compound - See Analyte.

Detection Limit . The method specifled detection limit, which is the lower limit of quantitation specified by EPA for a method. Radian staff regularly assess their laboratories' method detection 1 imits to verify that they meet or are lower than those specified by EPA. Detection IImits which are higher than mothod limits are based on experimental values at the $99 x$ confidence lovel. The detection limits for EPA CLP (Contract laboratory Program) methods are CRQLs (contract required quantitation (Imits) for organics and CRDLs (contract required detection limits) for inorganics. Note, the detection limit may vary from that specifled by EPA based on sample size, dilution or cleanup. (Refer to factor, below)

EPA Method - The EPA speciffed method used to perform an analysis. EPA has specified standard methods for analysis of enviromental samples. Radian will perform its analyses and accompanying OC tests in conformance with EPA mathods unless otherwise specifled.

Factor - Default method detection limits are based an analysis of cloan water samples. A factor is required to calculate sample specific detection 1 imits based on alternate matrices (soll or water), reporting units, use of cleanup procedures, or dilution of extracts/ digestates. For example, extraction or digestion of 10 grams of soll in contrast to 1 liter of water will result in a factor of 100 .

Matrix - The sample material. Generally, it will be soil, water, air, oll, or sulid waste.

Radian Work Order - The unique Radian identification code assigned to the samples reported in the analytical summary.

Units - ug/L micrograms per liter (parts per billion); liquids/water ug/kg microgrems per kllogrem (parts per billion); soils/sollds ug/M3 micrograms per cubic meter; air samples $\mathrm{mg} / \mathrm{h}$ milligrams per liter (parts per million); llquids/water $\mathrm{mg} / \mathrm{kg}$ milligrams per kilogram (parts per million); solls/solids * percent; usually used for percent recovery of aC standards $\mathrm{uS} / \mathrm{cm}$ conductance unit; microsiemans/cent imeter $\mathrm{mh} / \mathrm{hr}$ millillters per hour; rate of settlement of matter in water NTU turbidity unit; nephelometric turbidity unit cu color unit; equal to $1 \mathrm{mg} / \mathrm{h}$ of chloroplatinate salt 
Radian Work Order $91 \cdot 04-180$

Analytical Report

05/01/94

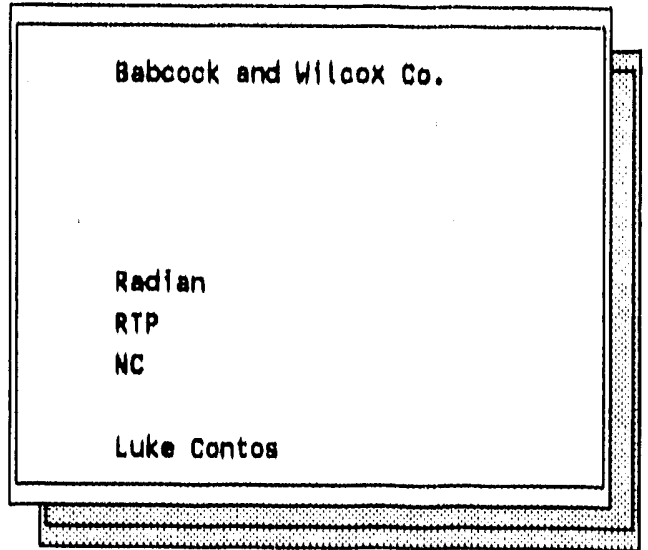

Cus tomer Work Identifloation Edgewater Purchase Order Number 209-026-05.00

Contents :

Analytical Data Sumary

Sample History

Corminits Summery

Notes and Definitions

Radian Analytical Services

8501 Mo-Pac Boulevard

P. O. B0X 201088

Austin, TX 78720-1088

$512 / 454 \cdot 4797$

Client Services Coordinator: KayOJNa

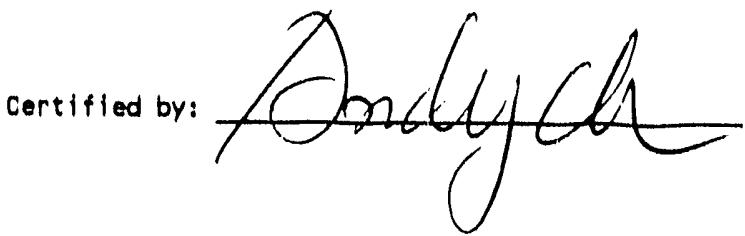


Babcook and Willook co.

Radian Work Order: 91-04-180

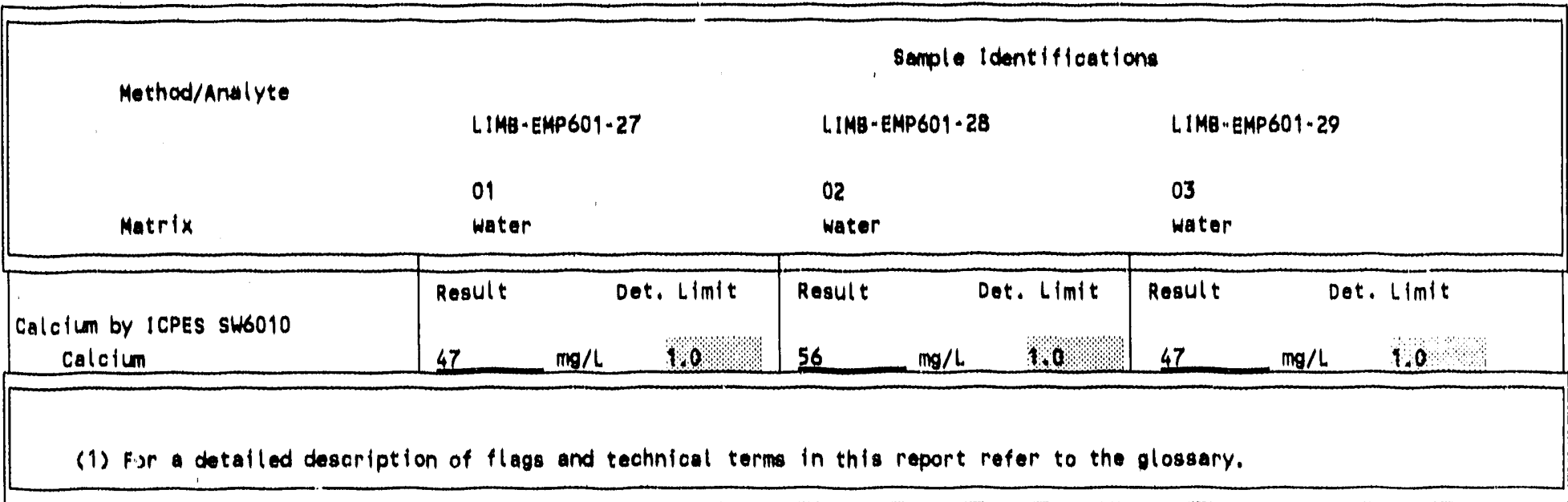


Babcock and Wilcox co.

Redien Work Order: 99.04 .180

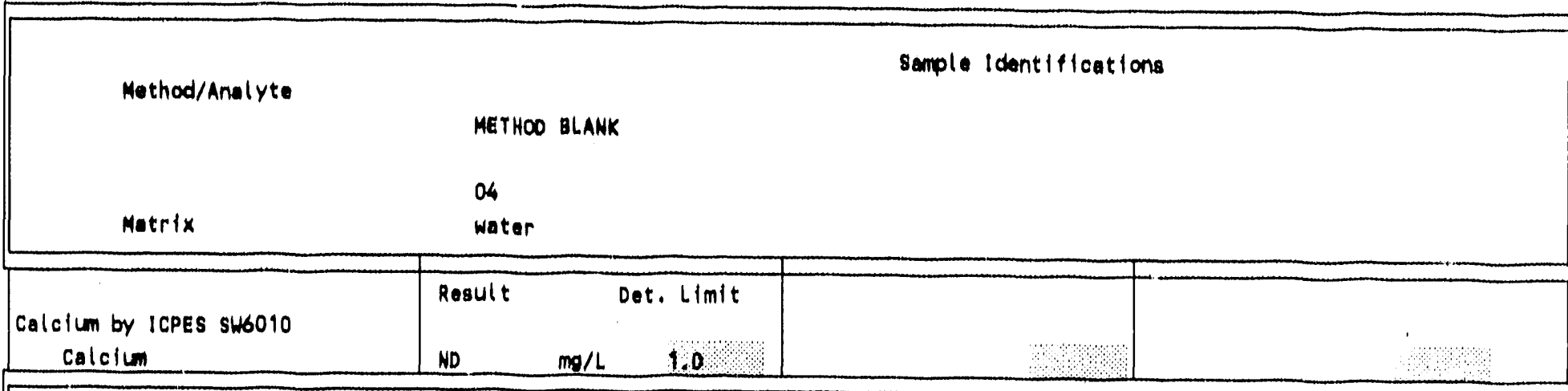

No Not detected at specified detection limit

(1) For detalled description of flage and technical terms in this report rafor to the glossary. 
Babcock and Wilcox Co:

Radien Work Order: 91-04-180

Sample Identifications and Dates

Semple 10

\section{Date Sampled \\ Date Received}

Matrix

LIMB-EMP601-27 LIMB-EMP601-28 LIMB-EMP601-29 METHOD BLANK

$\begin{array}{clll}04 / 15 / 91 & 04 / 15 / 91 & 04 / 15 / 91 & \\ 04 / 17 / 91 & 04 / 17 / 91 & 04 / 17 / 91 & 04 / 17 / 91 \\ \text { water } & \text { water } & \text { water } & \text { water } \\ 01 & 02 & 03 & 04\end{array}$

Calcium by ICPES SW6010

Prepared

Analyzed

Analyst

File 10

Blank iD

Instrument

Report as

$04 / 23 / 91$

04/25/91

DES

JA61

received
02

04/23/91

04/25/91

DES

JA61

received
$04 / 23 / 91$

04/25/91

DES

JA61

received received
$04 / 23 / 91$

04/25/91

DES

JA61

received 
Appendix A 
Babcock and Willcox Co.

Radien Work Order: $91-04-180$

ND ALL METHOOS EXCEPT CLP

This flag is used to denote analytes which are not detected at or above the specified detection limit.

EXPLAMATION

The value to the right of the s symbol is the method specified

detection limit for the analyte. 
Babcock and Wilcox Co.

Radian Work Order: $91-04-180$

TERMS USED IN THIS REPORT:

Analyte - A chemical for which a sample is to be analyzed. The analysis will meet EPA method and OC specifications.

Compound - See Analyte.

Detection Limit - The method specified detection limit, which is the lower limit of quantitation specified by EPA for a method. Radian staff regularly assess their laboratories' method detection limits to verify that they meet or are lower than those specified by EPA. Detection limits which are higher than method limits are based on experimental values at the $99 \%$ confidence level. The detection limits for EPA CLP (Contract Laboratory Program) methods are CRaLs (contract required quantitation limits) for organics and CRDLs (contract required detection (imits) for inorganics. Note, the detection limit may vary from that specified by EPA based on sample size, dilution or cleanup. (Refer to factor, below)

EPA Method - The EPA specified method used to perform an analysis. EPA has specified standard methods for analysis of enviromental samples. Radian will perform its analyses and accompanying aC tests in conformance with EPA methods unless otherwise specified.

Factor - Default method detection limits are based on analys is of clean water samples. A factor is required to calculate sample specific detection limits based on alternate matrices (soil or water), reporting units, use of cleanup procedures, or dilution of extracts/ digestates. For example, extraction or digestion of 10 grams of soil in contrast to 9 liter of water will result in a factor of 100 .

Matrix - The sample material. Generally, it will be soil, water, air, oil, or solid waste.

Radian Work Order - The unique Radian identification code assigned to the samples reported in the analytical summary.

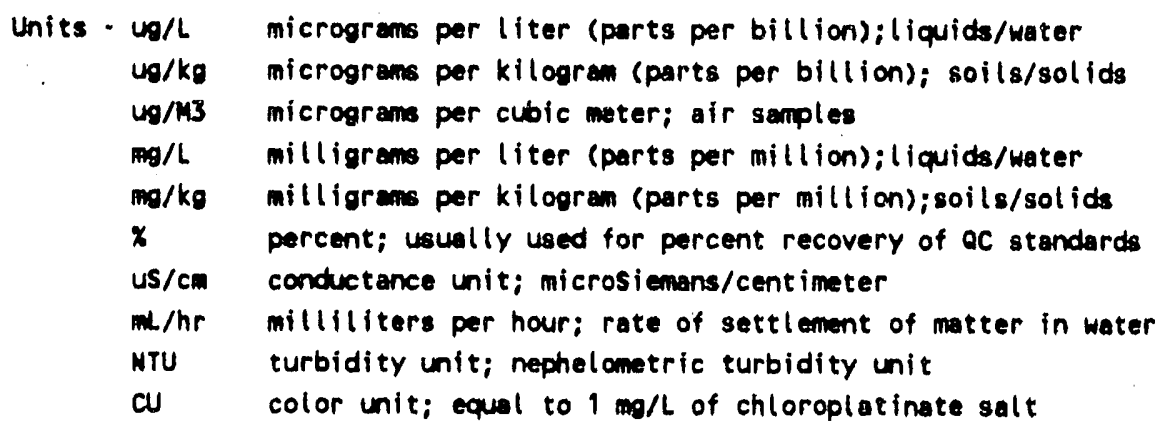


כ

APPENDIX E

TCLP AND ASTM DI LEACHATE PROCEDURES

-

-

-

- 


\section{LEACHATE METHODS SUMMARY}

Three leachate testing procedures have been discussed as viable methods to assess the chemical characteristics of leachate generated from LIMB fly ash. These three are the EP Toxicity Test, Toxicity Characteristic Leaching Procedures (TCLP), and a DI Water "shake extraction" ledatigh procedure. All three methods are included in this appendix and the following partagraphs generally summarize these methods as they pertain to a dry (ash) sample.

The EP Toxicity test uses a leaching procedure as follows:

1) extract ash with 16 times its weight in DI water;

2) adjust $\mathrm{pH}$ to 5.0 if above and do not adjust if below;

3) agitate for $24 \mathrm{hrs}$ at approximate room temperature maintaining the $\mathrm{pH}$ at 5.0;

4) add approximately 4 times the weight of the ash of DI water; and

5) filter and analyze for $\mathrm{As}, \mathrm{Ba}, \mathrm{Cd}, \mathrm{Cr}, \mathrm{Pb}, \mathrm{Hg}, \mathrm{Se}, \mathrm{Ag}$, and various nonvolatile organics.

The TCLP procedure incorporates the following general steps:

1) preliminary extraction

- $\quad$ perform a percent solids analysis;

- $\quad$ perform particle size reduction if necessary;

- determine which of the 2 extraction fluids to use;

.- $\quad$ if volatiles are to be analyzed, use extract fluid \#1

-. $\quad$ if $\mathrm{pH}$ of $\mathrm{DI}$ extract is less than 5, use exfract fluid \#1

-. $\quad$ if $\mathrm{pH}$ less than 5 with DI extract add small amount of acid, heat and if still less than 5, use extract tluid \#1

-. $\quad$ otherwise use extraction fluid $\# 2$

- $\quad$ extraction fluid \#1 - Acetic Acid, $\mathrm{N} \cdot \mathrm{aOH}$, and water $(\mathrm{pH} \approx 4.9)$; 
- extraction fluid \#2-Acetic acid and water $(\mathrm{pH}=2.9)$;

- $\quad$ add 20 times the weight of the solids in the aliquot (use special digestion vessel when looking for volatiles);

- add extraction fluid and extract for 18 hours at $30 \mathrm{rpm}$ (ambient temperatures); and

- $\quad$ filter the slurry, measure $\mathrm{pH}$, and analyze the extract for metals and organics as per SW846 methods.

The DI water leveling procedure basically is completed as follows:

- $\quad$ perform solids analysis;

- add 700 grams aliquot of ash plus 6 times the aliquot weight in DI water;

- $\quad$ invert 25 times/minute for 3 minutes;

- $\quad$ agitate 48 hours on a piece of equipment that is equivalent to a "reciprocating platform shaker;"

- open, let settle for 5 minutes, separate solids by decanting, centrifuge, or filtering;

- filtering further by vacuum or pressure; and

- measure $\mathrm{pH}$ and analyze. 


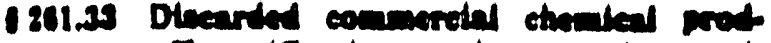

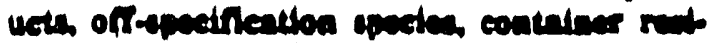
dow ead ofll realdeces thancer.

The following mutertils or Items are her

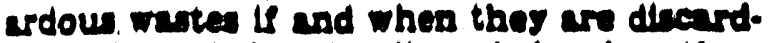
ed or intended to be dinourded unlen thes ure exaluded under 11200.20 and 200.22 and listed in Appendix DC

$\bullet$

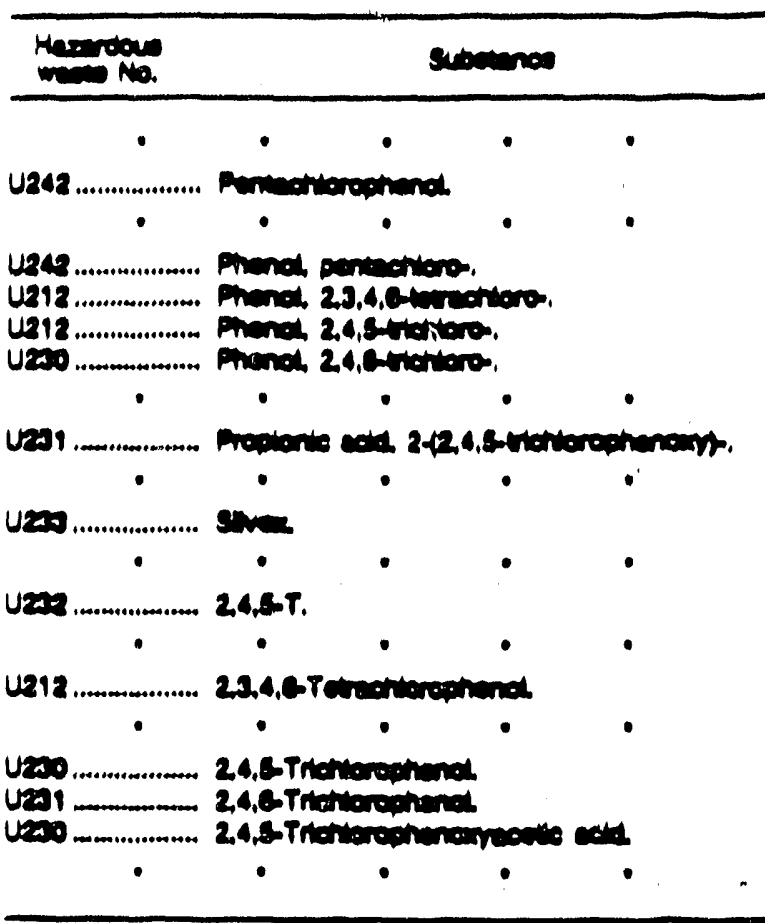

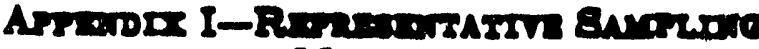 Mrroes}

The method end coulo...nent und los amplins wete anterith will res with the

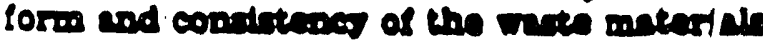

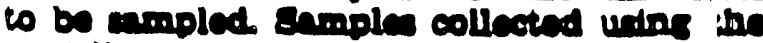
enoplins protecols lited bolow, for mo.

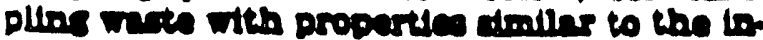
dicated meterting will bo conddered by the

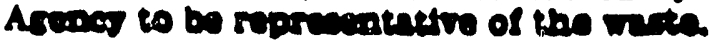

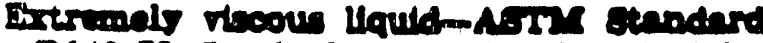
Diso-70 Crunted or poudisod mentel-

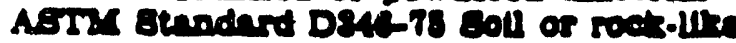

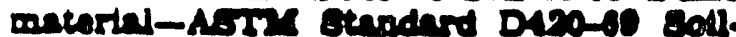

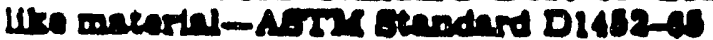

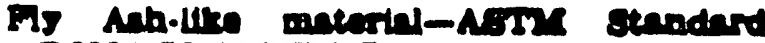

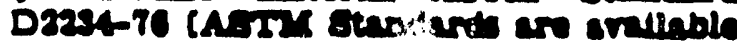

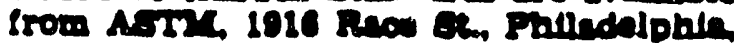
PA 101091

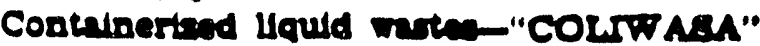
deacribed in "Teat Method for the ind. untion of Bolld Were. Phyded/Cheroled
Mothodi" O2 martronmented protec.

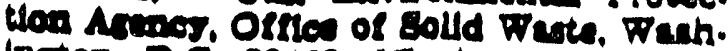

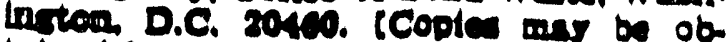
teloed frow solld Winte informatson. U.S.

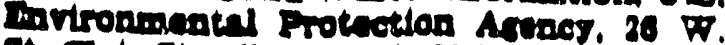

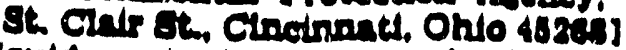

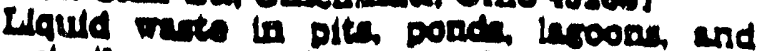

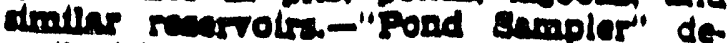

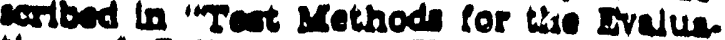

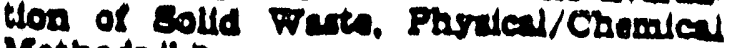
Mothoda." -

This onnus diso contulon edditionel in. formation on eppllention of then protocole.

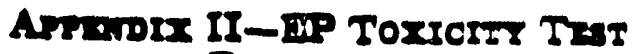 Froctovite}

\section{Etrection Procadure (LP)}

1. A ruprimentats enmole of the revte to

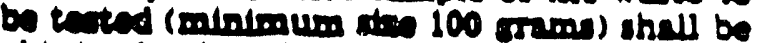
obtenined udas the mothode protpled in AD pacdir I ar ans other method capable of

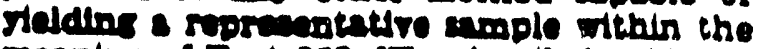
menoine of purt 290. IJor detulled ouldence

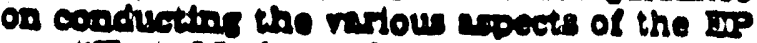
wo "Ifes Yethods for the Inviuntion of Golld Fine Finsicu/Cbemied Methods"

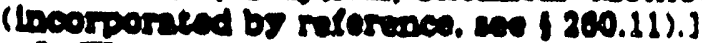

2. Ine enple tarll be copernted loto its compoevent lloutd and colld phenes untors the method deneribud la "Espuration Procedurs" bules. If the cold reddue o obtuined

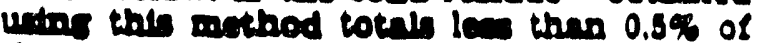
the ortenel walht of the were, the realdue an be divarided and the oporitor shell trint the lipuld phere is the extrict and proond lonodintels to bep a

3. The colld muterin obtalned from the

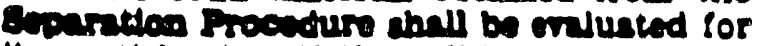

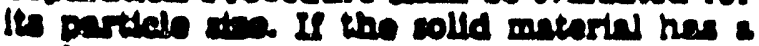

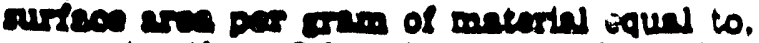
or cinter then $3.1 \mathrm{~cm}$ or pares throush s $0.5 \mathrm{~mm}$ (0.57s bab) etandind dere, the oper.

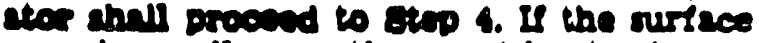

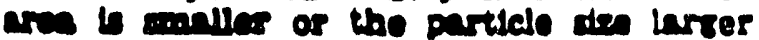

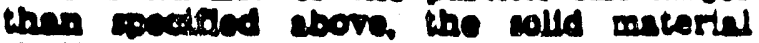
chill bo purpand for extarction by corisb.

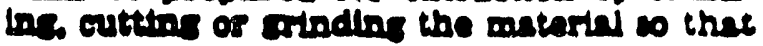

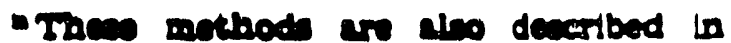

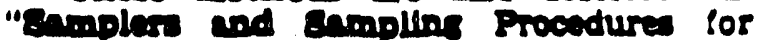

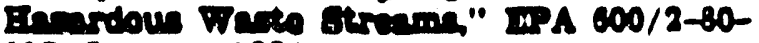
028 Jements $1 \mathrm{ch}$.

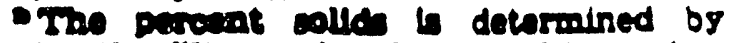

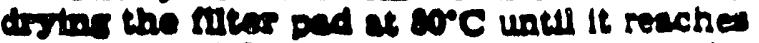

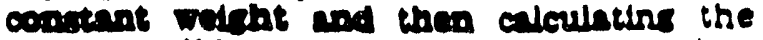
purent solld untas the followtat equation: Poreane solld a

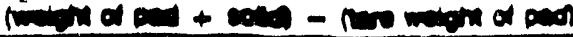
$\times 100$

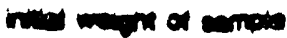


Eovirenmental Protection Acenoy

It prime throuch $9.8 \mathrm{~mm}(0.378 \mathrm{lnob}) \mathrm{dem}$ or. If the materte in 10 s dorde plece. bs oubjecting the onnterty to the "gitriotury intecerts Procedurs" denarbed bolow.

4. The colld mentertl obteined in step shrll bo welched and pleced in en exturnotor

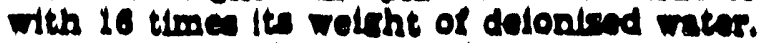
Do not allow the metorty to drs prtor to

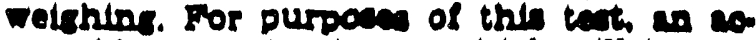
coptable extrnotor is one whleh will inpert ouseletent endtetion to the mixture to not only prevent strettiflention of the sample and extroction Auld but also brurs that all enple mireces are coptrauouls broushe lato conten with woll antred exturetion nuid.

8. After the colld mantortel and dolontend weter are plecend in the estarnoter, the oporen tor shril bedis edention and menerus the PE of the colution in the extrector. If the pE in treater thes B.0, the DE of the wolle. thos abll be doemend to $5.0 \pm 0.2$ by

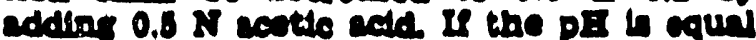
to or le the 8.0, no ecette sold chould bo addod The DE of the colution thill be moos leornd en deartiond below, durting the cours of the extraction and if the pla rim abow

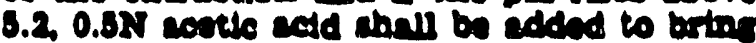

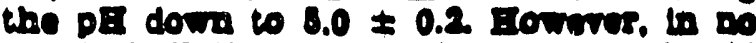

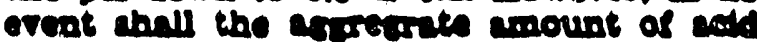
edded to the colvition exened 4 on of sedd

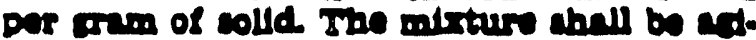
tated for 24 bours and matrenland it $20^{\circ}$.

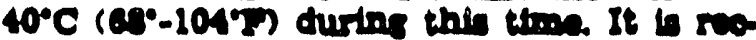
ommended thet the oparnter monttor and edjurt the DE durter the cours of the ez.

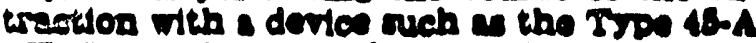

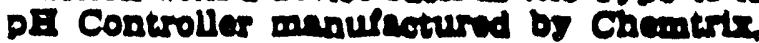
Ine. Ellinboro, Orven eries or les cautre

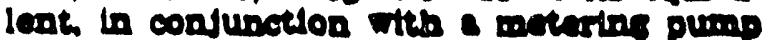

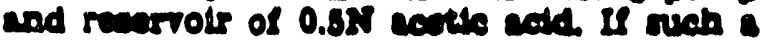
ssutem is aot avilinte. the followters menual procodure andl be caploged:

(a) A DE oncter abnll be clitured in es

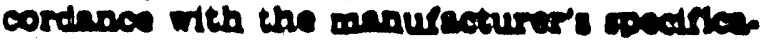
thom

(b) The pI of the soluttor still bo

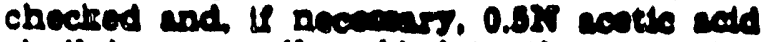

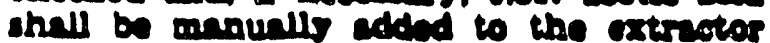
unedl the DE rache $8.0 \pm 0.2$ ing of of the solution thell be edfurted at 18, 20 and 60 minute lntermin movter to the next longer interva lo the pa dow not have to be edjurted moro bhe 0.319 pE unles.

(c) The edjurtacent procedur chall bo contlnued for at lent 8 bour.

(d) If at the and of the 24-bour extrotion pertod the pE of the colution 15 not boler 5.2 and the innetroum emount of add (4 m) Dor arm of collde) be act been edded the DE chall be adjuted to 8.0 t 0.2 and the ez. traction conthued for an edditfond four hourm durlne whleh the pa chall be edjur ed at one hour lotervils

6. At the end of the 24 hour extrnetlon parlod delonised weter shell be added to

\section{Pent 2:51, Apen $n$}

the extrueter th en emount detarminad by the lollowing equntion:

$V=(20 \times W)-16(W)-A$

$V$ - wh dolonterd water to be eddad

W-welebt in grens of colld abarned to ex. unctor

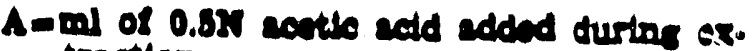
trettion

7. The menterlal in the uxtructor ibull by cropreed lote tes component llautd and

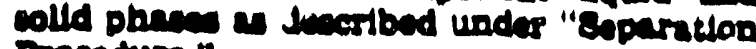
Proenduro."

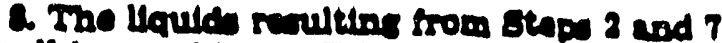

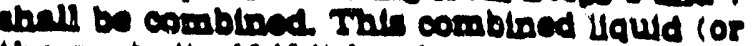

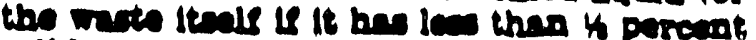
colldin so noted in the 2) is the extricot and chill be enclined for the prences of ang of

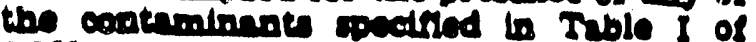
1201.24 uthe the Anvirticel procedure derinoted blow.

\section{Semaraton Proceders}

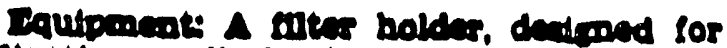

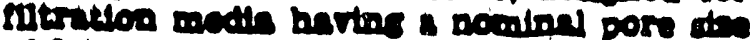

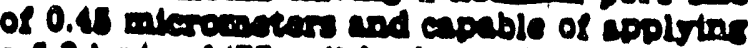

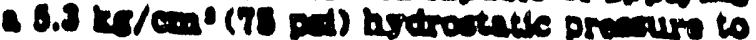
the colvetion botion meand shall be und

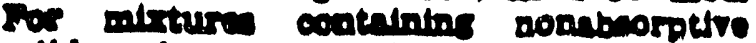

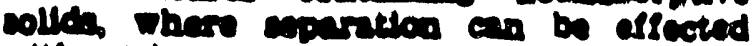

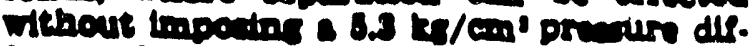

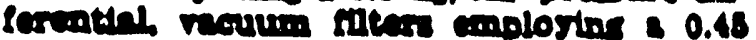

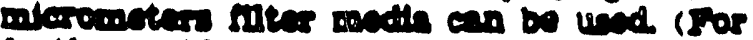

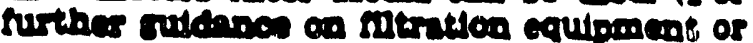

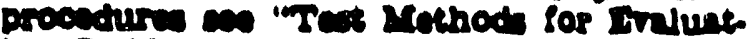

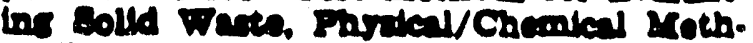
odp" locorporited by milerapos. we 1 200.11). Dreanduris"

(1) Jollowing mnoufecturers diroction the oftex ualt chall bo ancmbled with a

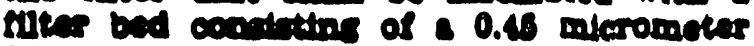

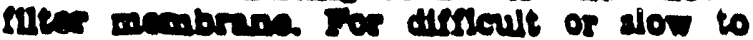

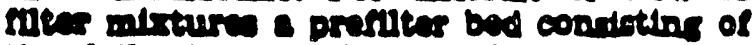

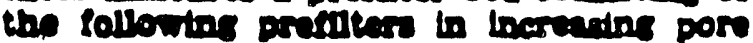

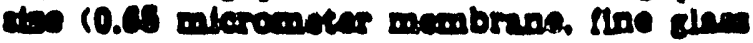

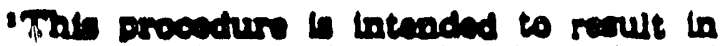

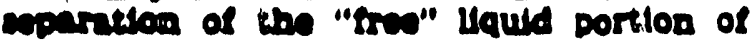
the wite trim ans colld mated bertas

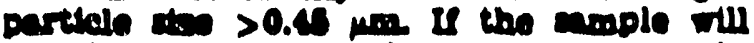

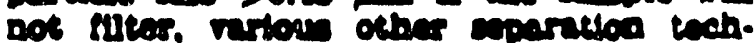
olque on be und to ald in the mitriven.

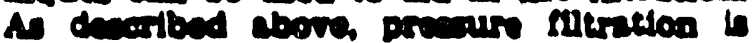

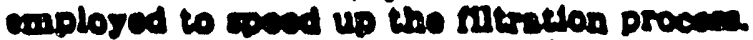

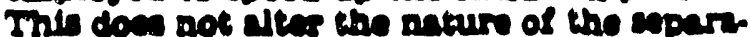

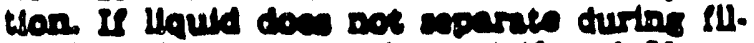
tration, the mate an be contrifuend If ep-

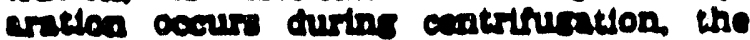

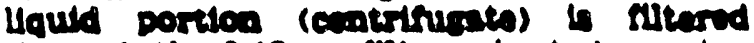
throunts the $0.16 \mathrm{~mm}$ tolecer prtor to becoming outred dith the lequid portlog of the reste obtalned from the Inith fithedion. Ans me. tortal that will not pen throush the pluter after centertucution is convidered solld and is extracted 
Pat 261, App. II

tlbar profulear, and conse slese libar pros eliter) and be unad.

(II) The wente dhall be poured lato the (ll. tration unit.

(III) The resorvolr andll be dowly prowour. tred untll llauld bedin to now from the fll. trate ouklet at whlch polot the prearure in the ellter shall be tromodintaly lowered to 10-18 pots. Futration thell bo contloued untll uquid now cescen.

(Iv) The preasure shall be locreaced stopwhe in 10 ped lneroments to 75 pats and fll. tration continued untll how cences or the

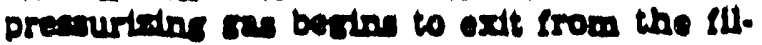
trate outlet.

(v) The fuler unit ahell be deprearurted the colld muteritel remored and welebed and thes tranderred to the extaruction eppara. tule or, in the can of flad futrutton prtor to enclyds divearded Do not sllow the matertal retalned on the futer pad to dry prtor to volching.

(vi) The llquild phase shell bo stored at $4^{\circ} \mathrm{C}$ for rubequeat un la sthe 8.

\section{a. Structural Intoonty Procadurs}

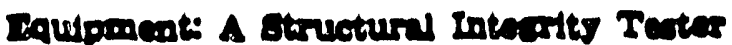

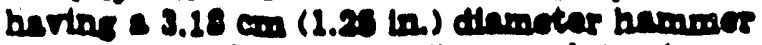
wolsbling 0.39 to $(0.73$ lbas) and hating irve fall of $18.24 \mathrm{~cm}$ ( 0 la.) andl be und

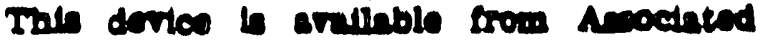
Decter and Mnnufecturing Compans, Alexendrin VA 29214 a Purt No. 128, or It mo be fabritented to meat the pectrication choora ba strune 1.
40 Can Cho 1 (7.1-15 Edtition)

Arocedurs

1. The cimple boldex chell bo ellled with the metartal to be laced If the sample of wite is a larye moselleble bloot, a portion thall be cut froen the bloct binters the df. mandow of $83.3 \mathrm{~cm}(1.3 \mathrm{ln}$ ) dinmetar $\times 7.1$

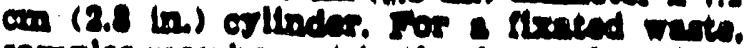
cmple may be cart in the form of $13.3 \mathrm{~cm}$ $(1.3 \mathrm{ln}$ ) dinmoter $\times 7.1 \mathrm{~cm}$ (20 in) orlinder for purpoces of conduoting this the In ruch ancen the were my bo allowed to oure lor 30 dare prior to further terting.

2. The enmple holder thell be pleced into the Etructurel intectity Terter. then the hammer chell bo rited to lts maximum helent and dropoed Thit abull be repeated ilreen timen

3. The matertel thell be removed trom the ample holder. Weiched and truncerred to the extarietion apparatus for extruction.

Arabticed Procudurn for Anabroino Istrect Concendruands

Tho tat mothods for andretng the ex. trect ase as follow:

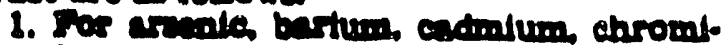

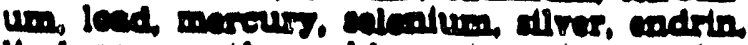

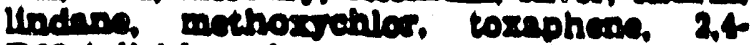

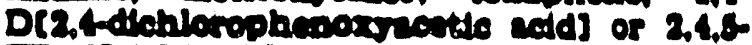

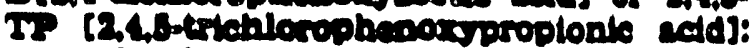

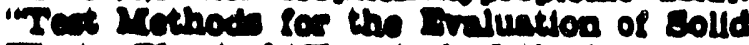

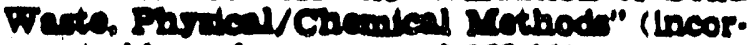
porrted by nifarion, eve (200.11).

2. Dinavinds

For ell envlyen the methode of standurd additton chell be ued for quanturication of

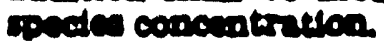



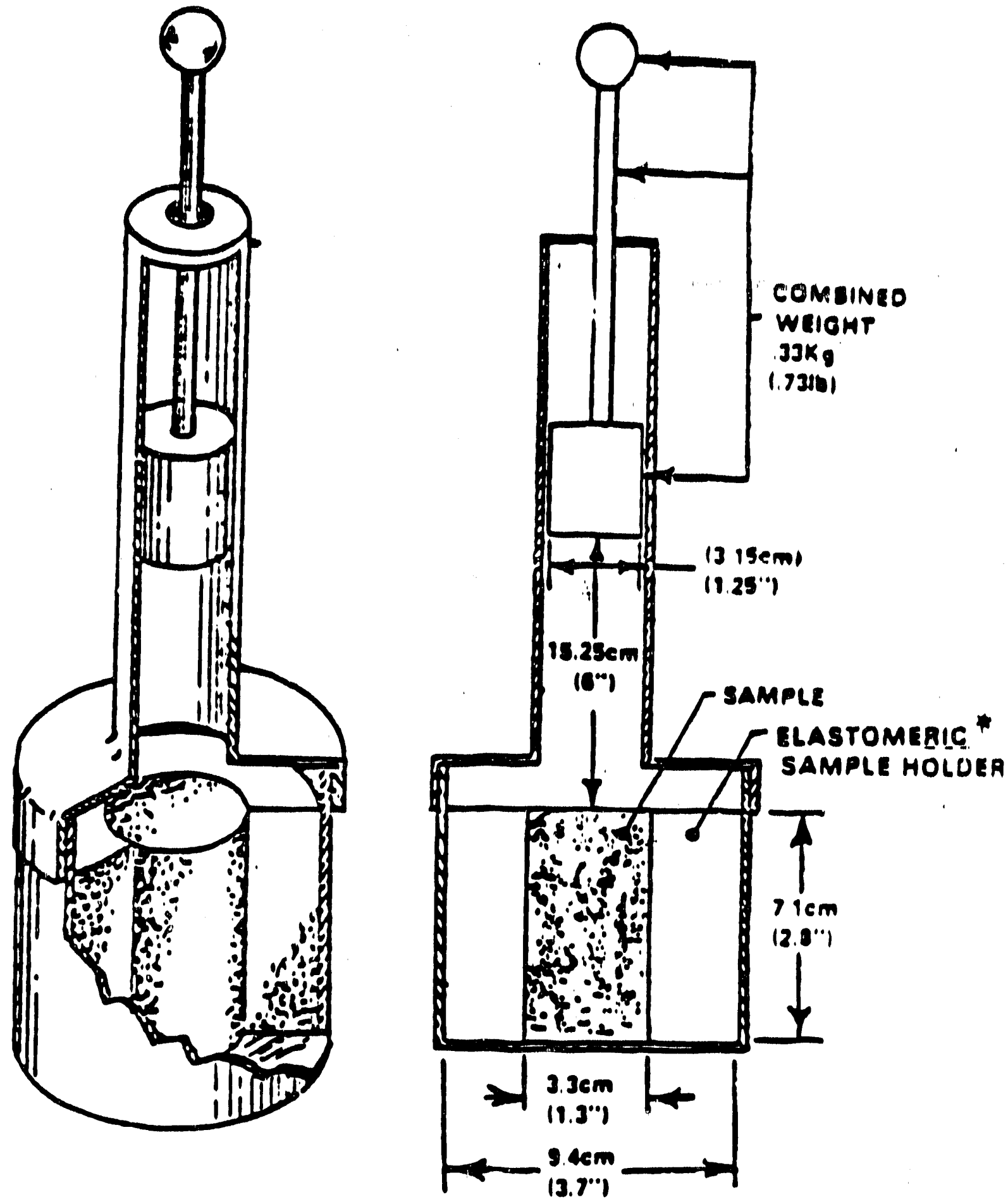

* elastomenic sample holoen ragnicateo or MATERIAL FIAM ENOUGH TO SUPPOAT THE SAMPLE

\section{Figure 1

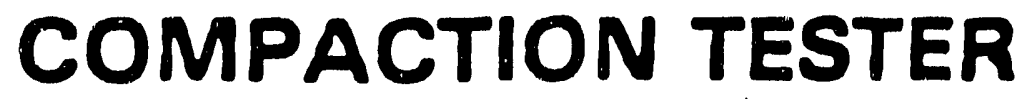

[46 FiR 33110. Mas 19, 1820, as amended at 46 FR 38247. July 7, 1901] 


\section{Standard Teat Mothod for SHAKE EXTAACTION OF SOLIO WASTE WITH WATER'}

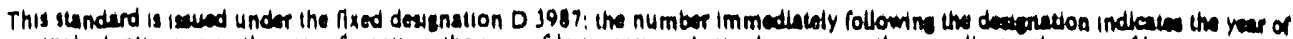

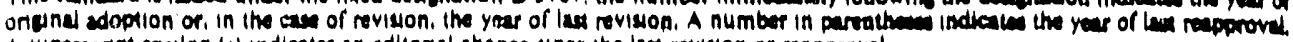
4 su.pericript epation (f) indicates an editoral chance suce the las reviston or reapopoval.

\section{Scom}

1.1 This method covers a procedure for leaching of solld waste to obtain an equeous solution to be used to determine the matertals leached under the specified testing conditions.

1.2 It provides for the shating of a known weight of waste with water of specified composition and the separation of the aqueous phese for unalyais.

\section{Appllaniso Docersents}

2.1 ASTM Standards:

D75 Pretice for Sampling Arreentes'

D420 Recommended Prictice for laveatientIns and Samplins of Soll and Rock for Encineering Purpocess

D1:29 Definitions of Terms Relating to Water

D 1193 Specification for Reaceat Water

D 1888 Test Methods for Particulate and Dis. solved Matter in Water

D2216 Method for Laboratory Deterraination of Moisture Content of Solls'

D 2777 Practice for Determination of Prectsion and Bins of Methods of Committen D19 on Water

D 2234 Method for Collection of a Gran Sample of Cont4

D 3370 Prectices for Sumpling Water

E 122 Recommended Prectice for Choice of Semple Sire to Extimute the A vernese Qunitiy of a Lot or Procend

\section{Straileanes and Un}

3.1 This method is inteaded as a rapld means for obcaining in extract of solid wate. The extrect may be used to entmete the relaese of certain constituents of the coltd wase under the laboratory conditions described in this pro. cedure.

3.2 This method is not Litsaded to provide an extract that is representintive of the ectual leschute produced from a solld waste in the field or to produce extracte to be ueed as the sole basis of engincering deatign.

3.3 This method is not intended to simulate site-specific leaching conditions. It bas not been demonstrated to simulate scturl disposal site leaching conditions.

3,4 If is intended that the find pH of the extract reflect the internetion of the extractant with the buffering capacity of the solid wate.

3.5 It is lentended thas ith water extraction simulate conditions where the solid wate is the dominant fector in determining the pH of the extract

3.6 The method produces an extrnet that is amenabte to the determinution of both major and minor constituents. When minor constituents are being determined it is espocially im. portant the precautions aro inten in sumpto storage and handling to avoid poatibla contam. incition of the samplea.

3.7 This method the becen teated to deter. mins its applieablitity to cerrain inorganic com. posents in the solld wrets (w0 Appendix XI). The method bis not been leated for applicabll-

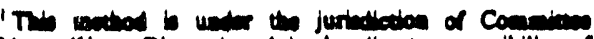

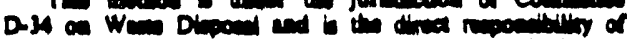

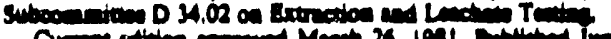
Ci. $1 \%$

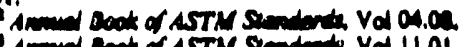

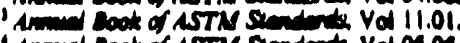

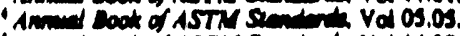

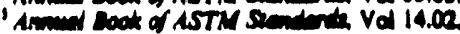


Aip

14 10 orrensio subatances and volatile mattor (i) 5,3).

3,8 The agdention technique and rate and the Haid-10-colld ratlo specified in the procedure Liquy not be suicable for extracting all types of wolid waste. (See discoussion la Appendix X2.)

+ Definditoas

4.1 For deftaitions of lerms used in this method, soe Definitions D 1129.

\section{Apperatuis}

9.1 Agitation Equipment-Agitation equip meal of any type that will produce constant novemeat of the aqueous phase equivaleat to nat of a reciprocatiog platform shaker opersled al 60 to 70 l.in. (25. $\mathrm{mm}$ ) cycles per minute whout incorporation of air is suitable. A oycle sall be understood to Laclude one forward and one equal return movement. Equipment used shall be designed for continuous operation without hosting the sumples being agdited (see discuselon of agitution in Appendix X2).

5.2 Membrane Fulter Assembly-A borodll. cale glase or stainlese steel funnel with a flat fritted base of the same material and membrane niliens.

5,3 Coniainers-Round, wide-mouch boltlea of composition sultable to the nature of the solid waste and the analyeses to be performed. and constructed of materials that will aot tullow sorption of constitueats of interest. One-gallon (or $4 L$ ) bottles should be used with $700-8$ samples and $12-g a l$ (or 2-L) bottles with 350-8 sumples. Multiples of these sizes may be used for larger sumples. These sizes were selected to esublish suitable geometry and provide that the sumple plus liquid would occupy approxdmately $801090 \%$ of the container. Boteles must bave a wateright closure. Containen for am. ples where gases may be relosend should bo provided with a veating mechanism. (Note thas the veating of the contuiner bas the potendal 10 affect the concentration of volatile extrects to the extract.) Containers sbould be cleaned in a menoer consistent with the andyeas to be performed.

\section{Renceests}

6.1 Purity of Reagents-Reapons grede chemicals shall be used in all ven Unien otherwise indicated, it is inteaded the all no agents stall conform to the speclifeations of the
American Chemical Soctery, where such spec. Lifations are avallabla" otber grades wny bo usech provided it is fint ecarrained that the reageat is of suffictently bigh purity to permit Its use without lescening the acouracy of the determination.

6.2 Purity of Water-Undess otherwise Lidl. cated. references to water stall be understood to mean Type IV reagent water at $181027^{\circ} \mathrm{C}$ (Speciflcation D 1193),

\section{Senplliog}

7.1 Obtain a represeatative sumple of the solld waste to be tested using ASTM sumple methods developed for the specufic industry where available.

7.2 Where no spectio methods are avallable, sampling methodology for materials of similar physical form shall be used.

7.3 A minimum semple of $5000 \mathrm{~g}$ shall be sent to the Laborntory (ee Method E 122).

7.4 It is imporiant that the sample of the solid wate be represencative with reapect to surface areh, as vartations in surface area would directly affect the leaching charnotertitics of the sample. Solid wente semples sbould contrin : represeacutive distribution of particles sizes.

7.5 Keep samplas in doand cootuinem appropriste to the sample type pritor to the exinaction in order to prevent sumple contamination or constituent loes. Where it is deatired to extract blologically or chemically sctive samples in their existing state store the samples as $4^{\circ} \mathrm{C}$ (Practices D 3370) and stert the extraction within $8 \mathrm{~b}$. Where it is deaired to extrect such sumplea in a state represeatative of the results of biological or chemical ectivitien the sumplas may be spectically bendled to simulate such activitian Record the storase conditions and bandling procedures in the report.

\section{Samplo Prepenatiom}

8.1 For tree-dowing particulate solid wasten obtain a supht of the approximate size $\pi$ quiral in the toa by quartoring the sumpla (Sectira 7 ) received for teating on an imper. mabla sbeet of glared paper, oil cloth, or other

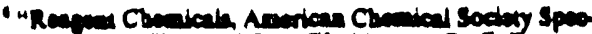

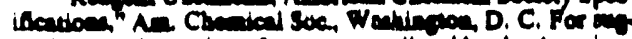

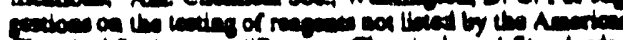

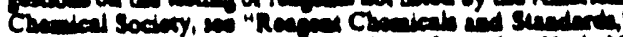

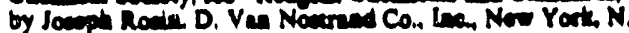

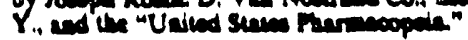


Naxible matorint as follow

8.1.1 Empoy the remple contrinax tato the center of the thenet

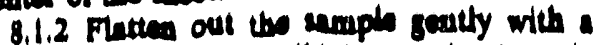

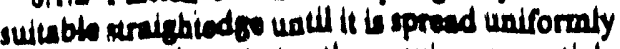
to a depth at least twice the meximum particlo dinmeter pardide sizo.

8.1.3 Remix the sumple by llating a coraer of the sheet and drawiag it actoan low dowa, to the opposite corner th a manner that the material is made to roll over and over and does not merely slide aloag. Continue operation with each corner, proceeding in a clockwits direction. Repent this operation ten times.

8.1 .4 Lin all four corners of the sheat to. wards the center and bolding all four cormers together, raive the ontire shoet into the air to form a pooket for the sumple.

8.1.5 Repant Stop 8.1.2.

8.1.6 With a strightedge at leas a long a the flattened mound of sumple (such as a thin. edged yard stick), geatly divide the sumple into quarters. An effort should be made 10 avoid using preasure on the straighedede sufficteat to caue demege to the particlea

8.1.7 Discand ditoroule quartors.

8.1.8 If turther reduction of sumpte sizo is peceasary, repeat Steps 8.1.3 through 8.1.7. A minimum unimpla size of $330 \mathrm{~g}$ is recommendad for each extraction. Additional sumples should be provided for determination of solids conteren. If smaller sumples are used in the tean, report this fact.

8.2 For field-cored solid westes or ceetion produced in the laboratory, cut is ropreantative section weighing approximntaly 350 or 700 for testing plus samples for determination of solids content. Shape the sumple so that the leaching solution will cover the material to be tested.

8.3 For fluid solid watech mix thoroughty in a manner that does not incorporate atr to semente uniformity bofor withdrawing a 350 or 700 sumple for teat. Take sumples for determinntion of solids content at the sume time as the the sumple.

\section{Procedin}

9.1 Record the physical decaription of the sample to be lested including partich itm 10 far as it is known.

9.2 Solids Contens-Dererentes the solids contert of seperate poritions of the smple as followis

9.2.1 Dry to constunt wedpht two dhbew on

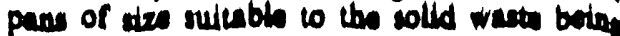
lound at $104 \pm 2^{\circ} \mathrm{C}$. Cool in a dedocitor and weigh Recond the value to $\$ 0.1 \mathrm{~g}$.

9,2.2 Put an approprizely stzed portion of sumple of the solid weste to be teatod lato ench pun. Scale the weighr used to the physical form of the solid wate teated. Une a minimum of so g but use larger sumplea where particlas large than $10 \mathrm{~mm}$ in average dinmoter are being teated. Weigh. Record the weight to $\pm 0,1 \mathrm{~g}$

$9,2.3$ Dry 16 to $20 \mathrm{~b}$ of $104 \pm 2^{\circ} \mathrm{C}$. Certute solid wastea such an scrubber sludgen may contain compounds that are subject to cald. antion at the specified drying temperature. Dry thea compounds at lower temperatures. Fo example. sypum may be succeinfully drted as $45^{\circ} \mathrm{C}$ (Muthod C 471) and CasO. $1 / 2 \mathrm{H}_{10} \mathrm{O}$ wasten at $85^{\circ} \mathrm{C}$. Record the setual temparatur and time of the drying period.

9.2.4 Cool to room comperaturs in a deato. cator and reweith. Record the woight to \pm 0.1 c.

9.3 Shake Procedurn-Woigh or tare the concuiner 10 bo used in the shice ten to the cenreat or within 1

9.4 Add the conchiner approximutaly 700 of solid wasta (Scotion 8) and decermitas and

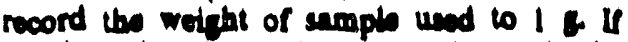
weiphte otber then $700 \mathrm{~g}$ are uned, note in the report.

9,5 Add to the container a volume of the water (6.2) equal in millilition to four tion the woight in grims of the sempin und in 9.4. Sw dicenesion of dilution ratio in Appeadix $\times 2$

9.6 Clowe the concuiner. Inveri the sontrines approximataty 25 times per minute for 3 min

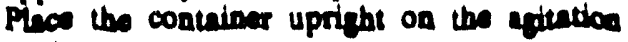
equipoment.

9.7 Apitute continuousty for $40 \mathrm{~b} \pm 0.3 \mathrm{~b}$ a $181027^{\circ} \mathrm{C}$

9.8 Dprea the container. Obensve and moond

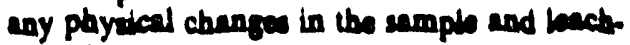
in coludion

9.9 Shate the containes to mix the entitro sampla thoroughly. Lat the sample forth mini then separnite the bult of the squecen phen trom solid phese by decancuidoen contute. unation, or filtrition through filter peper os appropitate. Then vecuum or prenours ellecer the liquid through $=0.45-\mu m$ fllter. If these epper retion meens result in prolonged filtering time 


\section{Allo}

, 8-um filler or other device may be used. peord any such dovitions in the report.

9.10 The filtrate obtriod in 9.9 is the exinct mentioned elsowbere in this merhod. Mearure we $\mathrm{pH}$ of the extract immedintely, then preserve the extract in a manner consistent with be chemical analysis or biological testing proiedures to be performed (Practicen D 3370). If sufficieat liquid phase is not available for the andyses. so indicate in the reporn and do not continue the procedure: or alternatuvely, perform the extraction procedure on additional samples of the solid waste 10 ubtain sufficieat liquid phase. Where phase separation occurs duriog the storage of the exiract, appropriz:s mixing shouid be used to ensure the homogeneity of the extract prior to its use in such anlysis or iesting.

9.11 Andyze the extract for specific constitvents or properties or use the extract for biological testing pruiedures as desired using appropriate ASTIM standard methods. Where no appropriate ASTM methods exist, other meth. ads may be used and recorded in the report.

\section{Caleulation}

10.1 Culoulate the solids content of the individual samples from the dats obtained in 9.2 as follows:

$$
S=A / B
$$

where:

$A$ - weight in grams of sumple after drying $B=$ original weight in grams of sample, and $S=$ solid content $g / 8$.

Average the two values obtained. Record as the solids content.

\section{Repont}

11.1 The report shall include the following:

11.1.1 Source of the solid waste date of sempling and ample preservation usech.

11.1.2 Description of the solid waste includins physical chnructeristics and particle size, if knowa $(9,1)$,

11.1.3 Solids content (9.2),

II.1.4 Sample weight if other than $700 \mathrm{~g}$.

I1.1.5 Drying time and temperature if other than 16 to $20 \mathrm{~b}$ at $104 \pm 2^{\circ} \mathrm{C}$.

11.1.6 pH and results of specific analyseo calculated in appropriate units. State analytical procedures used. and filter used if other than $0.45 \mu \mathrm{m}$.

11.1.7 Observation of changes in test mate. rial or leaching solution recorded in $\mathbf{9 . 8}$.

11.1.8 Date leach teating startud preserva. tion used for extrach and date of analysis.

\section{Proctalon and Accuracy}

12.1 No information is presently available as to the precision or accuracy of the andyais of specific constituants is the extract. It is res. ommended that users of this teat validals the applicability of their chosen methods of detec. tion by spiking portions of the extruct. before using these methods for the andyris of tha extrect.

12.2 Besed on a collaborative series of teats on six solid wante including ty anh, serubber sludge API separator sludge, onel finishing waste, textile waste, and soil the precision of iron and calcium determinations for theas specifle solid wastes was mearurod. Informution on the teat program is provided in Appendix XI.

12.3 Tho precisios of this method may vary depending on the solid waste being teated and on the eloment being extractod.

12.4 Determination of the eccurncy of this motwod is not poesible, as no rundard references material exiats. 


\section{APPENDIXES}

\section{X1. COLlaborattVe test PROGRAM}

XI.I Based on a collaborative series of tests on six solid waste including ny ash. scrubber sludge. API separator studge, motal finisbing wate, lextile wete. and soil the precision of this method for thesespecific materiale, including veriabulity of the extraction tea and the analytical procedure, may be expreased as shown below. Tweaty one laboratories participated in the collaborative teat program. and each of the six solid wates was tested by at lenst five of the labora. tories with a single opentor performing three exiraction replicalea The collaborative tex protran wes conducted with boch an unclear dafinition of wbether a stroke constituted foward-rturn move. meat (2es S.1) and without the inversion instruction (se 9.6). It he not been determined bow this contributed to the oberrved deviation.

X1.1.1 For culcium in concentrations nnging be tween 2.8 and $220 \mathrm{mCl}$ :

$s_{1}=0$ s11 $x+9.26$
$S_{0}=0.192 x-1.59$

where:

Wh - overall precision,

S. - single-operator precision, and

$X$ - determined concentration of $\mathrm{CL}_{\mathrm{m}} \mathrm{m} / \mathrm{L}$

$X 1.1 .2$ For iron in concentrations ranging from 0.05 and $1.4 \mathrm{mg} / \mathrm{L}$ :

$S_{1}=0.792 X-0.013$

$S_{0}=0.543 X-0.023$

where:

$S_{1}$ - overall precision.

$S_{0}$ - sinfleopernior precision, and

$X$ - determined concentritioa of Fe, my/L 'The collaborative dar en on the 4 ASTM Headquer.

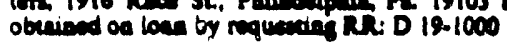

\section{X2. AGTTATION TRCTINIQUE AND RATh AND LQUD/SOLD RATIOS}

X2.1 Whils the major effort relutive to devalop meat of the cen method has beces underiteren at the egitution ras and liquid/solid ration spocined in the method it is recuppized that the variables may. significandy influence the renulte on cerrain solid wates and thes they may nor be edequate for cortuis solid waste.

X2.1.1 The posuble effocts of verying the apits. tion technique and rate include de rev of mirine tres of release of constituents and partich sbration ef. fech. The procition of the anthod mey alvo be inflo. ancind.

X2.1.2 The ponible ofcats of varying the ditution

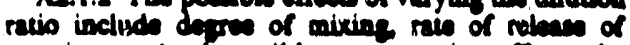
costituents (and poujble concentrution effects do

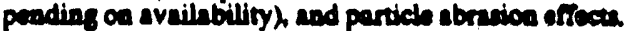

X2:2 The ariurion tochniques and ratio and th lation metio ued by other propoend extrection onth. ods difice from thow used is init wethod.

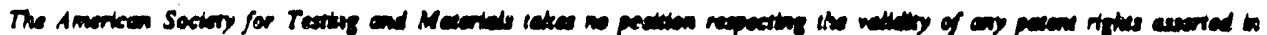

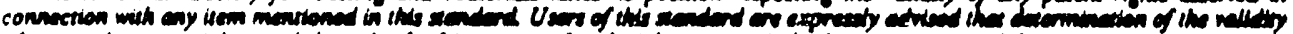

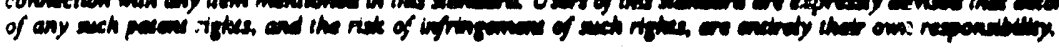

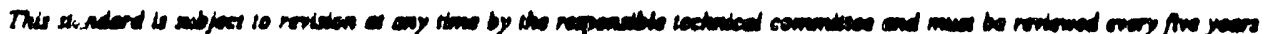

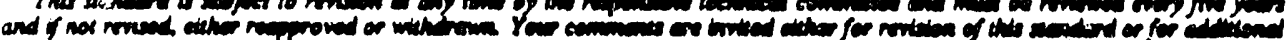

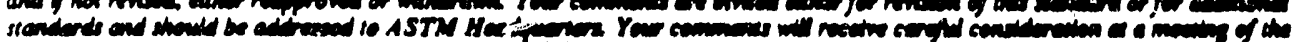

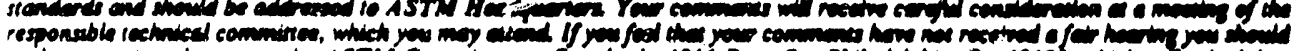

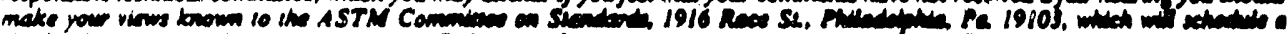

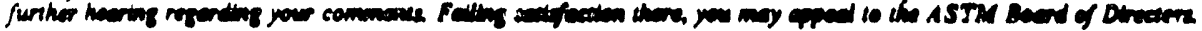




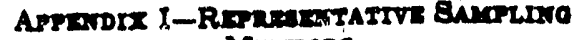
Mrrzode

The method and equlponent used for sempling weste materts' will vary with the form and consintency of the wete matertal to be sumpled. Sumples collected uning the sumpline protocols listed below. for sum. pling wente with properties similer to the in. dicated materials, will be cotilidered by the Agency to be representative of the waste.

Extremely viscous llquld-ASTM Standard D140-70 Crushed or powdered mntertalASTM Standard D346.75 Soll or rock-llke material-ASTM Standard D120.69 Soll. like materta--ASTM Standerd D1482-08

Fly Ash-llke matertal-ASTM Standar D2234-76 [ASTM Standards are avallable from ASTM, 1910 Race St., Philedelphle PA 19103\}

Containerized liquid wentean- "COWWASA" described In "Teat Methodl for the DVul uation of Solid Waste. Physlcal/Chemical Methods," U.S. Environmental Protec ilon Agency, Offlce of Solld Waste, Wesh. Inston. D.C. 20460. (Coples may be ob. trom Solld Waste Information. U.S. Environmental Protection Agency. $26 \mathrm{~W}$. Environmental Proteution Azency,

St. Clalr St., Clncinnatl. Ohio 45288) similer reservoirs. - "Pond Sempler" described in "Test Methods lor the Bvalus. tion of Solld Waste. Physteal/Chemieal Method.".
This menuel siso contelns additional in. cormetion on epplfentiok of thees protocoln.

\section{Appondix II-Mothod 2511 Taxidity} Charecteribtic Leaching Procedure (TCLP)

Revised by 55 FR 11862, March 29. 1990]

\subsection{Srope and Application}

1.1 The TCLP is desianed 10 datermine the mobility of botb orgente and Inorganic contaminants presert in Hquid. soltd, and multiphasic wastes.

1.2 If total analysis of the werte demonetrates that individual cuntaminants are not present in the waste, or that they are presellt but at such low concentrations that the appropriate regulatory thresholds could not possibly be exceeded the TCLP uned not he run.

1.3 If an analysis of eny one of the liquid frection of the TCLP extract indicales that regulated compound is present al such high levels that even after accountiug for dilution from the other fractions of the exiract the concentration would be above the regulator threshold for that compound. then the waste is hazurdous und it is not nerussary to aralyze the remaining fractions of the extract.
1.4 If an analysis of extract obtained using a bottle extractor thows that the concentration of any regulated volatile contaminant exceeds the remulatorv throsbold fur that compound, then the waste is hazardous and extraction using the $\mathrm{ZHE}$ is not neccssary. Itowover, extruct from a botlle extroctor cannot be used to demonetrate that the concentration of volatile compound is below the regulatory threshold.

2.0 Sunimary of Atsthod (sea Flgurs \%)

2.1 For liquid wastes (i.e.. those cuntaining lose than 0.5 percent dry solid material), the waste, after fittration throust a 0.6 to 0.8 -um glass nbor filter. is defined as thi TCLP extract.

2.2 Fur wastes containing greater than or equal to 0.3 percent solide, the liquid. if any. is separated from the solid phase and stored for later analyois: the solld phase, if necessery, is reduced in particle vize. The solid phase is extracted with an amount of extraction fluid equal to 20 times the weight of the solid phase. The axtraction fluid employad is a function of the alkalinity of the sulid phase of the waste. A special extractor vensel is usod when testing for volatite coniaminants (see Table 1 for a list of voldtila rompuunds). Following extraction, the liquid extract is sepiarated from the solid phase hy filtration through 0.6 to 0.0 -um gliss fiisin filter. 
rigues I Methed 1318 Flovehaxt

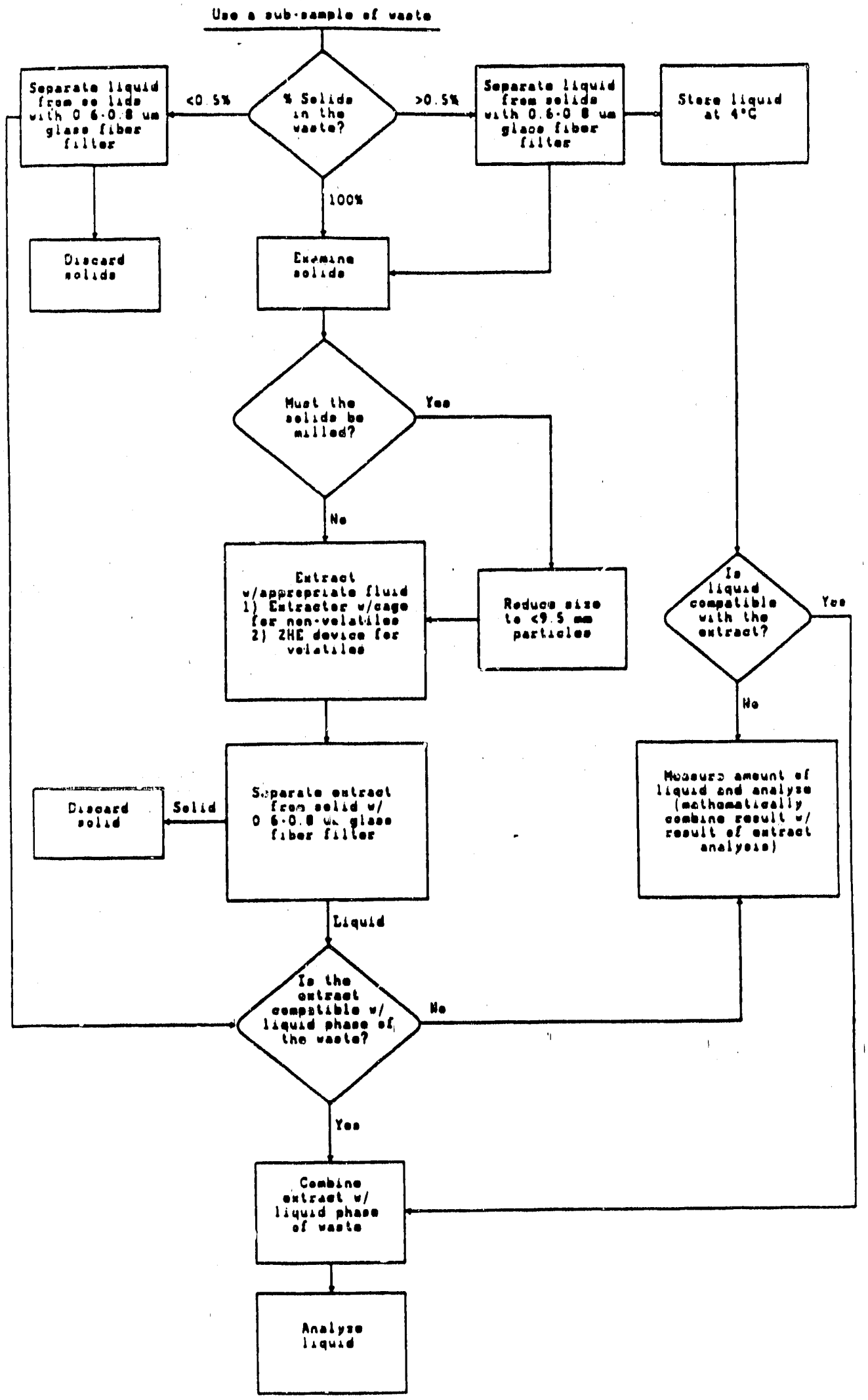

[Appendix II] 
Tagle 1-Volatile Contaminar:ts '

\begin{tabular}{l|r|}
\hline & Compound \\
\hline
\end{tabular}

table 1.-Volatile Contaminants 'Continued

\begin{tabular}{l|l} 
Compound & CAs no. \\
\hline y & 1230-20-7
\end{tabular}

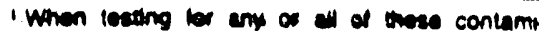
nont the zerohendsonse extrector weel thall be used inutese of the botth extrector.

2.3 If cumputible (l.e., multiple phases will nut form on combination, the initial liquid phase of the waste is added to the licuid extract. and these are anolyzed regether. If incumputible, the liquids are anulyzed separately and the resulte are mathemuticislly combined lo yicld a volume-weighted nieruge cuncentrution.

\subsection{Interfitences}

3.2 Potential interferences that mav lie unrountered during analysin are discussed in the indisidital analytical meithnds.

\subsection{Apparalus and Materials}

4.1 Agiation appuratua: The ogitatinis upparatus muat he capable of rotaling the extraction vasuel in an end-over.end hashion (see Figure 2) of $30+2 \mathrm{rm}$. Sultable devices known to SPA are identified in Table 2.

4.2 Extraction Vessul:

4.2.1 Zero.lteadupece Extrartion Vessil (Zf IE). This device is fer use only when the waste is being tested for the mobility of volatile constituents (i.e.. those listod in

Table 1). The ZHE (dejicted in Figure 31 ullows fir liquid/solid onparation within thr device, and uffectivaly preclurtes headspare. This type of vessel allows fur initial liquid/ solid separution. extraction. and finul extract filtration without upening the vessel (see step 4.3.1). The vessels sball have an internal volume of $500-600 \mathrm{~mL}$ and be equipped to Hccommodate a $90-110 \mathrm{~mm}$ fater. The Jevicus contain VITON 1 a-rings which should be replured frequently. Suitable $\mathrm{ZHE}$ derices known to F.PA are identified in Tablos.

I VITSON* is is Iriaitumark of Ua Ponl.

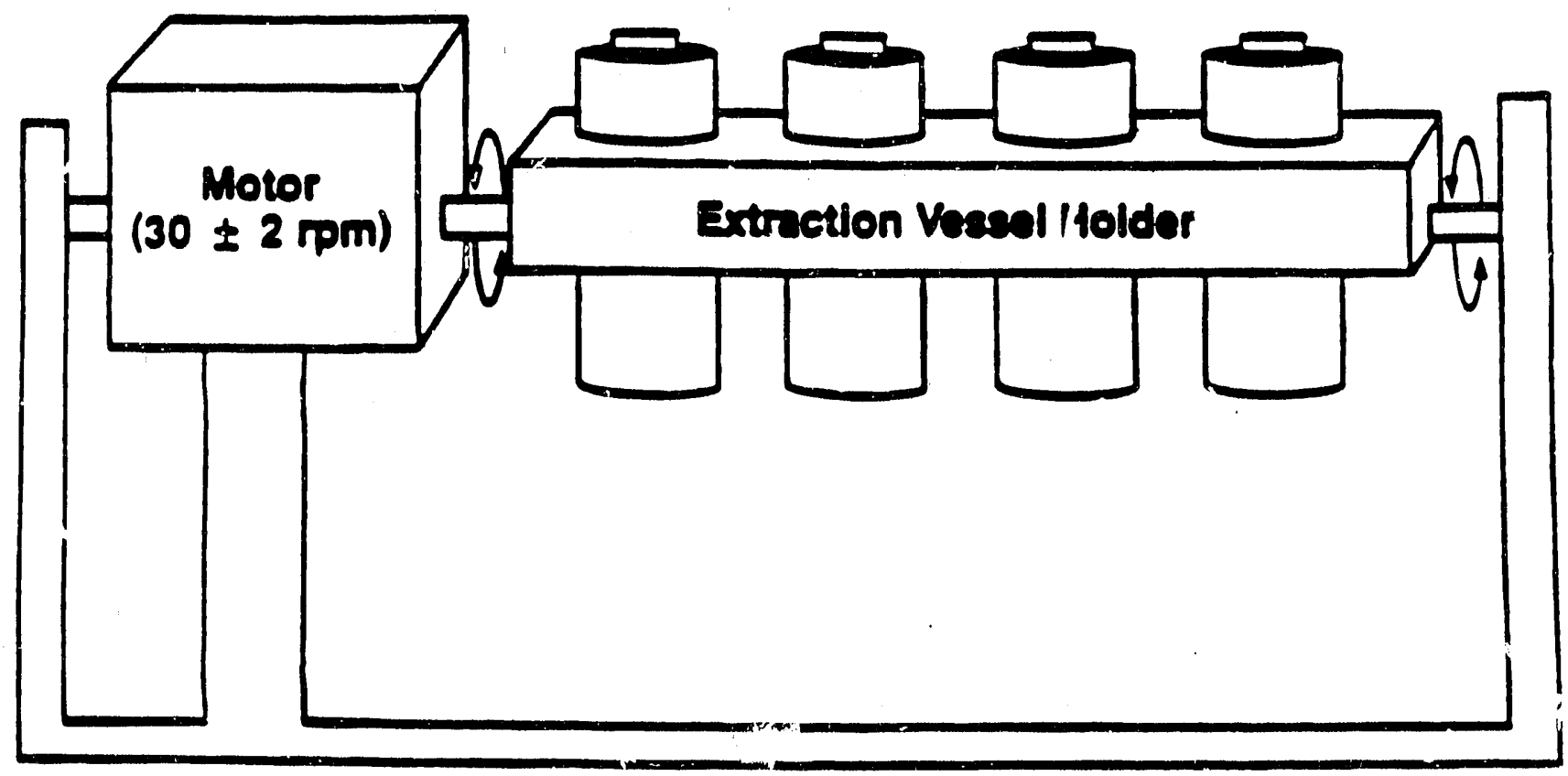

Figure 2. Rotary Agitation Apparatus

[Appendix II] 
Table 2.-Suitagle Rotary AGtation appaaAtus '

\begin{tabular}{|c|c|c|}
\hline Compeny & Location & Modet na \\
\hline 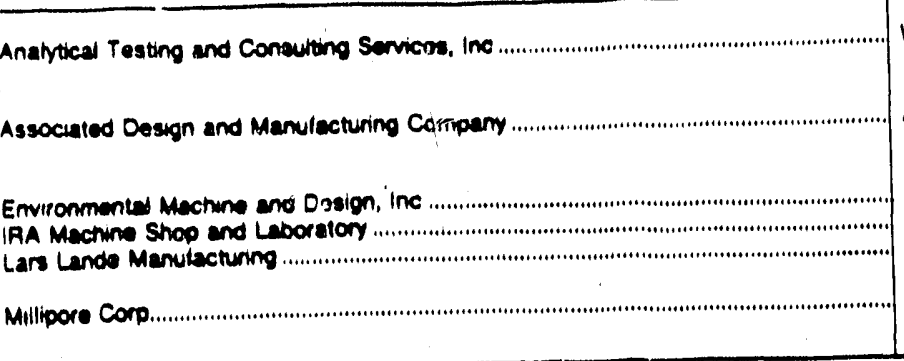 & 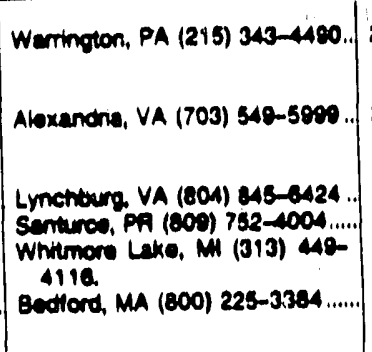 & 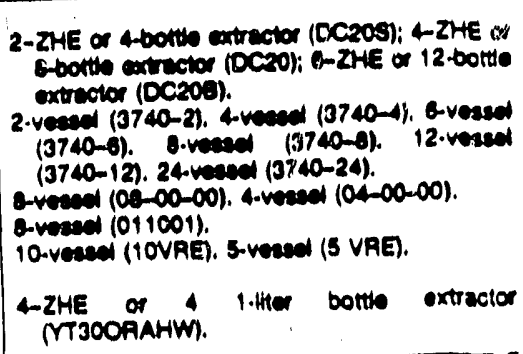 \\
\hline
\end{tabular}

I Amy device that rolutes the cxtrection veased in en end-over and techion at $30+2$ ipm is ceceptable.

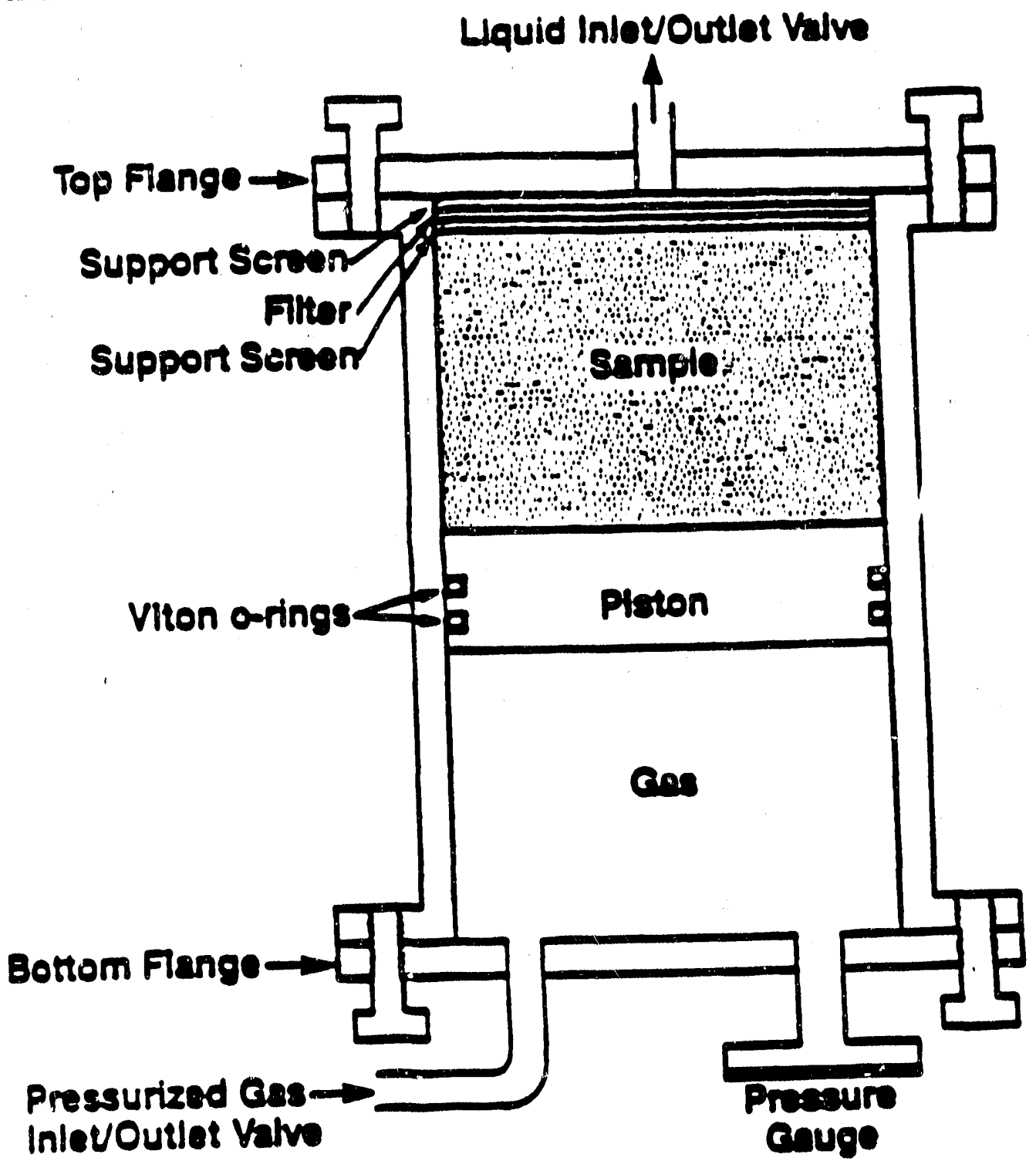

Figure 3. Zero-Headspace Extractor (ZHE) 
table 3.-Sujtable Zero-Headospace Extaactoa Vessels I

\begin{tabular}{|c|c|c|}
\hline Compeny & Location & Mode no. \\
\hline 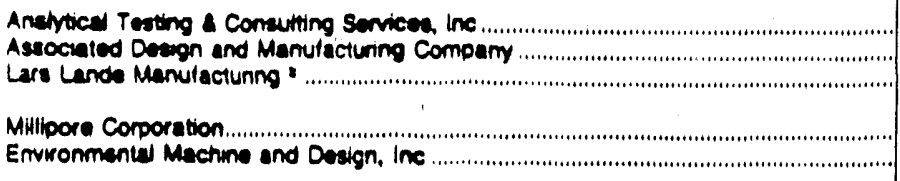 & 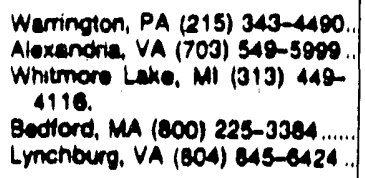 & 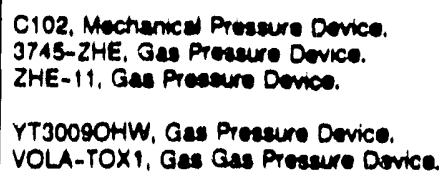 \\
\hline
\end{tabular}

Any derice that meats the specitications listed in Section 4.2 .1 of the mothod is curtuble.

- This cunce vees $110 \mathrm{~mm}$ fitter.

For the $\mathrm{ZHE}$ to be acceptable for use, the piston withia the ZHE should be able to be moved with approximately 15 poi or lese. If it takes more presaure to move the piston. the O-rings in the device should be replaced. If this does not solve the problem, the ZhE is unacceptable for TCLP analyees and the manufacturer should be contacted.

The ZHE ahould be checked for leake after every extraction. If the device contains a built-in pressure gauge, pressurize the device to 50 pal, allow it to atand unattended for 1 hour, and recherik the pressurn. If the device does not have a built-in presure gauge. pressurize the device to 50 psi, submerge it in water, and check for the presence of air bubbles escaping from any of the fittings. If pressure is lost, check all fittings and inspect and replace $\mathrm{O}$-rings, if necessary. Retest the device. If leakage probleme cannol be solved the manufacturer ihould be contacted.

Some ZHEs use gas pressure to actuate the $Z H E$ piston, while others usn mechanical pressure (see Table 3). Whereas the volatiles procedure (see section 9.0) refors to pounds. per-equara-inch (poi), for the mechanisally actualed pioton, the pressure applied is measured in torque-inch-pounde. Refer to the manufacturer's inatructions ae to the proper conversion.

4.2.2 Bottlo Extraction Vessel. When the waste io being evaluated using the nonvolatile extraction. jar with oufficient capacity to hold the ample and the extraction fluid is needed. Headopace is allowed in this vessel.

The extrection boltles may be constructed from various materiale, depending on the contaminants to be analyzed and the nature of the wate (see Step 4.3.3). It in

recommended that borosillicate glase bottles be used instead of other types of glase. especially when inorganics are of concern. Plautic bottles. other than polytetrafluoro. ethylene, shall not be used if organics are to be inveatigated. Bottles are available from a number of laboratory suppliers. When this type of extraction veseel io used. the filtration device discussed in Step 4.3.2 is used for initial liquid/solid separation and final extract filtration.

4.3 Filtration Devices: It is recommended that all filtratione be performed in a hood.

4.3.1 Zero-Headspace Extractor Vessel (ZHE): When the waste io evaluated for volatiles, the zero-headepace extraction vessel described in section 4.2.1 la used for filtration. The device shull be capable of supposting and keeping in place the glase fiber fllter and be able to withstend the pressure needed to accomplish ceparation (50 pai).

Notu: When it is suspected that the glase fiber filter has been ruptured, an in-line glase fiber filter may be used to filter the material within the ZHE.

4.3.2 Filler Holder. When the wasle is evaluated for other than volatile compounda. any filter holder capable of supporting a glase fiber filter and able to withetand the pressure needed to accomplish aeparallon may be used. Sultable filter holdere range from simple vacuum units to relatively complex systeme capable of exerting pressures of up to 50 psi or more. The lype of nlter holder used depends on the propertien of the material to be filtered (see Step 4.3.3). These devices shall have a minimum internal volume of $300 \mathrm{~mL}$ and be equipped to nccommodate minimum filter size of $47 \mathrm{~mm}$ (filter holders having an internal capacity of $1.5 \mathrm{~L}$ or greater and equipped to accommodate $112 \mathrm{~mm}$ diameter filter are recommended). Vacuum filtration can only be used for wastes with low solids content $1<10$ percent) and for highly granular liquidconiaining wastes. All other types of wastos should be filtered using pooltive pressure filtration. Suitable filter holders known to EPA are shown in Table 4.

4.3.3 Matertals of Construction:

Extraction vesuels and filtretion devices shull be made of inert matertals which will not leach or absorb waste components. Glass. polytetrafluoroethylene (PTFE), of type 318 stainlese steel equipment may be used when evaluating the mosility of both organic and inorganic componente. Devices made of highdenaity polyothylene (HDPE), polypropylene. or polyvinyl chloride may be ueed only when ovaluating the mobility of metals. Boroailicate glase bottles are recommended for use over other types of glase bottlee, capecially when inorganice are conetituente of concern.

Table 4.-Suitable Filtea holdeas '

\begin{tabular}{|c|c|c|c|}
\hline Company & Location & Modal/Catalogus no. & Size (um) \\
\hline 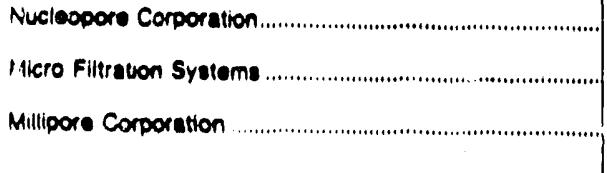 & 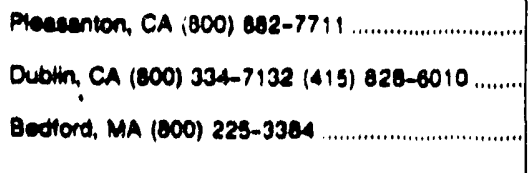 & 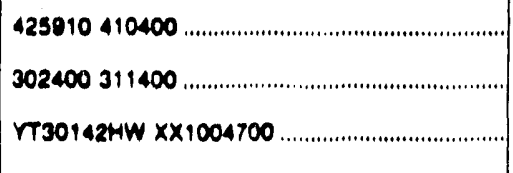 & $\begin{array}{l}142 \mathrm{~mm} \\
47 \mathrm{~mm} \\
142 \mathrm{~mm} \\
47 \mathrm{~mm} \\
142 \mathrm{~mm} \\
47 \mathrm{~mm}\end{array}$ \\
\hline
\end{tabular}

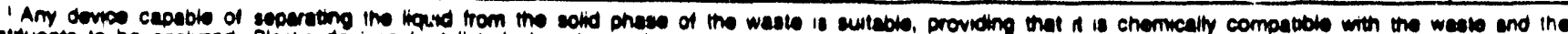

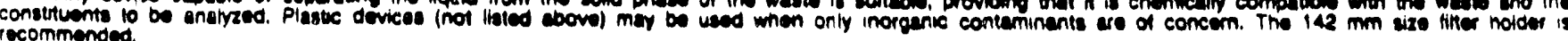

4.4 Fillers: Filters shall be made of borosilicate glase fibor, shall contain no binder materials. and shall have an effective pore size of 0.6 to $0.8-\mathrm{um}$ or equivalent. Filtere known to EPA which meet these specilications are identified in Table 5. Pre. filtors must not be used. When evaluating the mobilliy of metals. filters shall be acid. washed prior to use by rinaing with IN nitric acid followed by three consecutive rinses with deionized distilled waler (a minimum of 1.L per rinae is recommended). Class liber filturs are fregile and should be hundled wilh care.

$4.3 \mathrm{pH}$ meters: The meter ahould be accura!e to +0.05 units at $25^{\circ} \mathrm{C}$.

[Appendix II] 
TAgLE 5. - SUITAQLE FILTEA MEOHA

\begin{tabular}{|c|c|c|c|}
\hline Compen & Location & Model & Pore \\
\hline 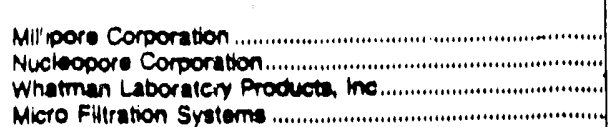 & 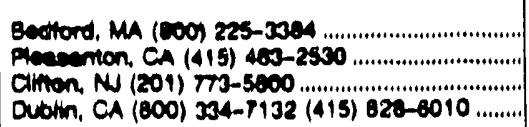 & 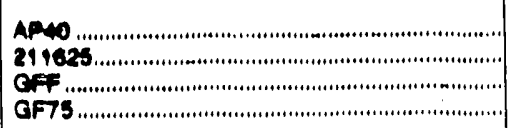 & $\begin{array}{l}0.7 \\
0.7 \\
0.7 \\
0.7\end{array}$ \\
\hline
\end{tabular}

'Amy filter that moets the spectications in Section 4.4 of the Mothod is witede.

4.6 ZHE exiract collection devices: TEDLAR ${ }^{n 2}$ bags or glase, stainless steel or PTFE gas-light syringes are uaed in collect the inits lliquid phase and the final exiract of the waste when using the ZHE device. The devices liwed are recommended for use under the following conditions:

4.6.1 If a waste cantains an aqueous llquid phase or if a waste does not contain a significant amount of noraqueous liquid (1.8.. $<1$ percent of total waste), the TEDLAR bas or a $600 \mathrm{~mL}$ syringe should be used to collect and combine the initial liquid and solid extract.

4.6.2 If a waste contains a significant amount of nonaqueous liquid in the initiul liquid phase (i.e., $>$ I percent of total waste). the syringe or the TEDLAR bas may be used for bott the initial solid/llquid separation and the final extract futration. However. analysts should use one or the other, not both.

4.6.3 If the waste contains no initial liquid physe (is 100 percent solid) or has no significant solid phase (is 100 percent liquid). either the IEDLAR" bag or the syringe may be used. If the syringe is used. discerd the first $5 \mathrm{~mL}$ of liquid expressed from the device. The remaining aliquote are used for analysic.

4.7. 2HE extraction fluid transfer devices: Aryy device capable of transferting the extraction fluid into the $\mathrm{ZHE}$ without changing the nature of the extraction fluid to ucceptable (e.g. a positive displacement or peristaltic pump, a gne tight oyringe, pressure filtration anit (See Step 4.3.2), or other ZHB device).

1.8 Laboratory balance: Any laboratory bulance accurate to within + 0.01 grame moy be used (all weight measurements are to be within +0.2 grams).

\subsection{Reagenis}

5.1 Reagent water. Reagent water io defined as waler in which an interferant is not observed at or above the methods detection limit of the analyte(s) of Interest. For nonvolatile extractions. ASTM T ype il water or equivalent meots the definition of resgent waler. For volatile extractions, it is recommended that reagent water be generated by any of the following methods. ketigent wuter should be monitured periodically for impurities.

5.1.1 Reagent wates for volutile extractions may be generated by passing lap wuter lhrough a carbon filter bed containim about 500 gram of activated carbon (Calgon Curp., Filtrasorb.300 or equivalent).

5.1.2 A water purification syatem (Millipore Super.Q or equivalent) may uleo be used to generpte reagent water for volatile extractions.

2 TEILL.AR" is a regielered irndemark of Du Punt.
5.1.3 Reagent water for volatile extractione may also be prepared by boilling water for 15 minutee. Subsequently, whil maintaining the water temperature at $\boldsymbol{\varphi}+5$ -C, bubble conteminant-free inert oas (e.g. nitrogen) through the water for 1 howr. Wbile still bot transfer the water to a narrow mouth screw-cap bottl under sero-heodepece and seal with Tofon-lined exptum and cap.

5.2 Hydrochlorto acid (IN) HCh ando from ACS reagont grade.

5.3 Nitric acid (1N), HNO. made from ACS reagent grode.

5.4 Sodium bydroxide (IN). NuOH, made from ACS reapent grude.

5.5 Glacial acetic acid. HOAc. ACS reagent grade

5.6 Extraction Duid.

5.6 .1 Extraction flutd $* 1$ : Add $5.7 \mathrm{~mL}$ glacial HOAc to 500 on of the appropriate water (See Step 5.1), add QL3 an of iN $\mathrm{NaOH}$, and dilute to a volume of 1 liter. When correctly prepared. the pH of this duld will be $4.95+0.05$

5.6 .2 Extrection fluid $* 2$. Dilute $5.7 \mathrm{~mL}$ glacial HOAe with ASTM Type II water (See Step 5.1) to a vohume of 1 liter. When correctly prepared the pH of this fluid will be $2.80+0.06$.

Noter These extraction fluids should be monitored frequently for imparities. The pH should be checked peitor to use to ensure thet thees fluide are made up accuretely. If impurities are found or the $\mathrm{pH}$ is not within the bove opecifications, the flubd thall be diecarded and tresh extraction flujd prepared.

5.7 Analytical standarde properect accorting to the appropriate analytice method.

0.0 Sample Colloction, Preservation, and Handling

6.1 All samples shall be collocted uoing en appropriate campling plat.

6.2 The TCLP may place requirements on the minimel size of the field eample depending upon the physical state or states of the weste and the contaminants of concem. An aliquot is needed for preliminary evaluation of which extraction fluid is to be used for the nonvolatile contaminant extraction procedure. Another aliquot may be needed to actually conduct the nonvolastle extraction (see section 1.4 concerning the ues of this extract for volatile orgenical if volatile organice are of concarn, enother uliquot may be needed. Quality control measures may require additional aliquots. Further, it is always wise to collect more sample fust in cuse something goes wrong with the initial altempt to conduct the test 6.3 Preservatives shall not be added to sumples.
6.4 Samples may be refrigeraled unless refrigeration results in irreversible physical change to the waste. If precipitation occure the entire cample (including precipitate) should be extracted.

6.5 When the waste is to be evalualed for volattle contaminants, care shall be taken w minimize the loss of volatiles. Samples ahall be laken and stored in a manner to prevent the lose of valatile contaminants (e.8. samples thould be collected in Teflon-lined septum capped vials and stored at ${ }^{\circ} \mathrm{C}$. until ready to be opened prior to extraction).

6.6 TCLP extracts thould be prepared for analyais and analyzed es scon as possible following extraction. Extracts or portions of extracts for metallic contaminant determiostions muel be acidiffed with nitric acid to $a \mathrm{pH}<2$ undess precipitation occurs (see section 8.14 if precipitation occurs). Extracts or portions of extracts for organic contaminent determinations shall not be allowed to $70 \mathrm{me}$ into contact with the atmouphere (le.. no headspace) to prevent looses. See cection 10.0 'QA requirements) for acceptable eample and extract holding timea.

\subsection{Proliminary Evaluations}

Perform preliminary TCLP evaluations on a minimum 100 gram aliqout of waste. This aliquot may not actually undergo TCLP extraction. These preliminary evaluations include: (1) determination of the percent olide: (2) determination of whether the wact contains insianificant solide and is. therafore. its own extract after filtration: (3) determination of whether the solid portlon of the waste require particle size reduction: and (4) delermination of which of the two extraction fluids are to be used for the nonvolatile TCLP extraction of the waste.

7.1 Prellminary determinution of percent colide: Percent solide le defined as thet fraction of a waote sample (as a percentuge of the total sample) from which no liquid mHy be forced out by an applled preseure, at described below.

7.1 .1 If the waste will obviously yield no tree llquid when subjected to pressure filtration (l.e.. is $100 \%$ solide) proceed to Step 7.3 .

7.1.2 If the sample is liquid or multiphasic liquid/solid separation to make preliminary detorminution of percent solids is required. This involves the filtraiton device described in Step 4.3 .2 and b oullined in Stepe 7.1.3 through 7.1.8.

7.1.3 Pre-weigh the filter and the container that will receive the filtrate.

7.1.4 Assemble the fllter holder and filter following the manufacturer's instructions. PHace the filter on the support screen and secure.

[Appondix II] 
7.1.5 Weigh out a rubeample of the waste (100 gram minimum) and record the weight.

7.1.6 Allow slumies to stand to pormit the solid phase to sectle. Wastes that eettio slowly may be centrifuged prior to filtration. Centrifugation is to be uned only ae an aid to filtration. If used. the liquid should be decanted and filtered followed by filtration of the solid portion of the waste through the same filtration system.

7.1.7. Quantitatively transfor the waste sample to the filtur hulder !liquid and solid phases). Spread the waste sample evenly over the surface of the fllter. If altration of the waste at $4^{\circ} \mathrm{C}$ reduces the amount of expressed liquid over what would be expressed at room tamperature then allow the sample to warm up to room temperature in the device before nilering.

Note: If wyste material (>1 percent of original sample wuight) has ubviously adhered to the container used to transfer the gample to the filtration apperatus, determine the weight of this residue and subtruct if rom the sample weight determinod in Stop 7.1.5 to delermine the weight of the waste sample that will be filtered.

Creduality apply vecuum of genthe presoure of 1-10 poi, until air or presuurizing gas movee through the filter. If this point is not rewchod under $10 \mathrm{pot}$, and if no sdatitionel llagid has passed through the filter in any 2-munute interval, slowly increase the presoure in 10: pai increments to a maximum of 30 pai. After each incremental lacreace of 10-ped. L the pressurizing gas has not moved through the filter, and if no additional liquid has paseed. through the filter in any 2-minute interval: proceed to the next 10-pei increment: When the pressurizing gas begtna to move through the filter, or when liqud. Sow hes cenced at 50 pui (i.e. filleation does not result in any additional filtrete withia any 2-arinute period), atop the filtration.

Noter instontansous application of high pressure can degrade the gluse fiber filter and may cause premelare pluogias

7.1. The matertal in the filter bolder is defined as the solid ptases of the waots, and the filtrate is defined as the liquid phese.
Notes Some whotes, nuch in otly wastes and some paint waster, will obviously contain some materia! that appears la be a liquid. Even afiar applyiag vacuum or pressure filtration an outlined in Step 7.1.7. this material may not filtar, 4 thio ia the case. the material within the flltration dexice is deliaed as a solid. Do not raplace the original filter with a frah filter uader any circumstances. Use only one filter.

7.1.9 Determin- the woighr of the llauid phase by subtracting the weight of the filine te container (soe Step 7.1.3) from the lotal weight of the flltrate-filled containor. Delermine the waight of the solid phese of the waste samule by subtrecting the weigbt of the liquid phace from the weight of the tolw waste sample, as determined in Stap $7,1.5$ or $7,1.7$.

Recond the weingti of the liquid and solid phases. Calculate the percent sollde as folluws:

$$
\text { Percent solids }=\frac{\text { Weight of colid (Stap 7.1.9), }}{\text { Totel weight of waste (Step 7.1.5 or 7.1.7) }} \times 100
$$

72 If the percent solide determined in Slep 7.1.9 lo equal to or greeters then 0.35 . then proceed eilther to Siep 7.3 to determine whether the solid material requires particle yize reduction or to Step 7.2.1 if it is noticed that a small amount of the filtrate to entrained in wetring of the filter. If the percent solids delemained in Step 7.1.9 is lase than $0.5 \%$, then pruceed to Step 8.9 if the nuavolatile TCLP in to be performed and to snction 9.0 with a fresb portion of the waste if the volatile TCLP is to be performed.

7.2.1 Remove the solld phase and filter from the filtration apparatue.

7.3.2 Dry the alter and colid phase at 100 $+20^{\circ} \mathrm{C}$ until two successive weighing yield the same value within +1 percent. Record the final weight.
Now: Caution ahould be laken to ensucu that the subject solid will not ilesh upon. hesting. II is rocommended that the dryine oven be vented to a bood or other appropriate dovice.

7.2.3 Calculate the percent dry solids is follnwe:
(Weight of dry weate + Alme) - tared woight of filtor Initial woight of weate (Stop 7.1 .3 or 7.1 .7 )
100
7.2.4 If the percent dry solidb is less than 0.5 percent. then proceed to Step 8.9 if the nonvolatile TCLP is to be performed, and to Section 9.0 if the volatile TCLP is to be performed. If the percent doy elido is greater than or equal to $0.5 \%$, and if the nonvolatile TCLP is to be performed, retum to the liczinning of this Section $(7.0)$ and. with a fresh portion of waste. determine whether prorticle size reduction is necesessy (Step 7.3) arid delermine the appropriale extrection nuid (Step 7.4). If only the volatile TCLP is 10 te performed, see the nute in Slep 7.4.

7.3 Determination of whether the wade reqidires particle-size reduction (particle-size is reduced during thie step): Uaing the solid portion of the waste. evaluale the solid for particle sizo. Particie-size reduction is requiced. uniess the solid hes a oufface area per gram of material equal to or greater than $31 \mathrm{~cm}^{2}$, or is amatler then $1 \mathrm{cos}$ in its narrowest dimension (i.e., is capable of pessing through o $9.5 \mathrm{~mm}$ (0.373 inch) s!andard sieve). If the surface aren in smaller or the particle size larger than described above. prepare the solid portion of the waste for extraction by crushing, culting, or grinding the waste to a surface ares or particleryize as described above. If the solids are preparedt for organic volattles extrection, upecial precrutions must be taken. see Step 0:a

Note: Surface area criterie are meant fur fllamentous (6.8. paper, cloth, and imilar) waste materials. Actual meoourement of surface area io not required nor is lt recommended. For materiats that do not obvioualy meet the criteria, sampla-specific methods would need to be developed and employed to measure the surface area. Such methodulogy is currently not available.

7.4 Determination of appropriate exiraction fluid: If the solid content of the wasta is greater than or equal to 0.5 percent and if TCLP extraction for nonvolacile constituents will take place (Section 8.0), purform the determina/ion of the appropriate fluid (Step 5.6) to use for the nonvolutiles extraction as followe:

Note: TCLP extraction fur volatile constituents uses only extraction fluld $\approx 1$ (Step 5.6.1). Therefore, if TCLP extraction fur nonvolatiles is not required, procesd to Section 9.0.
7.4.1 Weigh out amall subeamplit of the solid phase of the wante, reduce. the enlid: (if necessary) to a particle-size of approximately $1 \mathrm{~mm}$ in diamoter or less, and tranafer 3.0 grame of the solid phase of the waste to a $500-\mathrm{mL}$ beaker or Erlenmeyer naek.

7.4 .2 Add $96.5 \mathrm{~mL}$ of reagent waler (AS'TM Type II) to the beaker, cover with a watcholase. and stic vigorously for 5 minutes using a magnetic stirter. Measure and record the $\mathrm{pH}$. If the $\mathrm{pH}$ is $<5.0$. use extraction fluid *1. Proceed to Section 8.0 .

7.4.3 If the pH from Step 7.4.2 is >3.0. add $3.5 \mathrm{~mL}$ IN IICl, slurr" 'rrienly, cover with H watchgiase, heat 10 sts 1 , and hold at $50^{\circ} \mathrm{C}$ for 10 minutes

7.4 s Let the solution cool to room tempe nture and record the $\mathrm{pH}$. If the $\mathrm{pH}$ is $<5.0$. I extraction fluid $\$ 1$. If the $\mathrm{pH}$ is $>5.0$. use extraction liuid $\neq 2$. Proceed to Stection 8.0 .

7.5 If the aliquat of the wante used for the preliminury evaluation (Steps 7:1-7,4) way determined to be $100 \times$ solid at Step 7.9.1. then it can be used for the Section 8.0 axtraction lassuming at least 100 grumn [Appendix II] 
remain), and the section 9.0 extruction (assuming at least 25 grams remain). If the aliquot was oubjected to the procedure in Step 7.1.7, then another aliquol shall be used for the volatile extraction procedure in Section 9.0. The aliquot of the waste subjocted to the p,ocedure in Step $7.1 .7 \mathrm{might}$ be appropriate for use for the section 8.0 extraction if an adequate amount of solid (as determined by Step 7.1.9) was obtained. The amount of colld necessary sopendent ispon whether aufficient amount of extract will be produced to support the unalyses. If an adoquate amount of solid remains, proceed to Slep 8.10 of the nonvolatile TCLP extraction.

8.0 Procedure When Volatiles Are Not IIIvolved

A minimum sample size of 100 grams (solid and liquid phases) is required. In some cases. a larger sample size may be appropriate. depending on the colids content of the wasts sample (percent solids, See Step 7.1), whether the initial llquid phase of the waste will bo miscible with the aqueous extract of the solid, and whether inorganics. semivolatlle organics, pesticides and herbicides are all analytes of concern. Enough solids should be generated for extraction ouch that the volume of TCLP extract will be sufficient to aupport all of the analysee required. If the amount of extract generated by aingle TCLP extraction will not be sufficient to perform all of the analyses, more than one extraction may be performed and the extracts from each combined and allquoted for analysis.

8.1 If the waste will obviously yield no liquid when uubjected to preseure filtration (i.e., is 100 percent solid, see Step 7.1), woigh out a subsample of the waste $(100 \mathrm{gram}$ minimum) and procend to Step 8.0 .

8.2 If the semple is liquid or multiphasic liquid/solid separetion is required. This involves the filtration device described in Step 4.3.2 and is outlined in Stepe 0.3 to 8.8

8.3 Pre-weigh the container thet will receive the filtrate.

8.4 Assemble the filter hoider and filter following the manufacturer's instructions. Hace the filter on the support screen and secure. Acid wash the filter if evalunting the mobility of metals (see Step 4.4).

Note: Acid washed filters may bo uoed for ull nonvolatile extractione even when metale are not of concerm.

Weight of extraction fluid
8.5. Weigh out a subsample of the wate (100 gram minimum) and record the weight. If the waste contains <0.8 percent dry solide (Step 7.2\%, the llquid portion of the weste. afier filtration. is defined es the TCLP extract. Therefore, enough of the eample should be filtered so that the amount of filtered liquid will support all of the analyses required of the TCLP extract. For wastes containing >0.5 percent dry colids 1Step 7.8 or 7.2$)$, use the percent colide information obtained in Step 7.1 io determine the optimum sample size (100 gram minimum) for filtration. Enough solida should be generated by filtration to oupport the analyses to be performed on the TCLP extract.

8.6 Allow slurrtes to stand to permit the oolid phase to settle. Waotss that settle sowly may be centrifuged prios to filtration. Use centrifugation only as an aid to filtration. If the waste is centrifuged, the llquid should be decanted and filtered followed by filtration of the solid portion of the waste through the same iltration syotem.

6.7 Quantitatively transfer the waste sample (liquid and colid phases) to the filter holder (see Step 4.3.2). Spread the waste sample evenly over the surface of the filter. If filtration of the waste $14^{\circ} \mathrm{C}$ reduces the amount of expressed liquid over what would bo expressed at room temperature, then allow the rample to warm up to room temperature in the device before filtering

Note: If waste material ( $>1$ percent of the origiral eample weight) has obvioudy adhered to the container used to transerer the semple to the filtration apparalus, determine the woight of this residue and subtract it from the sample weight determined in Step 8.5, to determine the weight of the waste sample that will be Altered.

Cradually apply vacuum or sentlo pressure of $i-10$ pot, until air or pressurizing ons moves through the filter. If this point is not reached under 10 pai, and if no additional llquid has paseed through the filter in any 2-minute inierval slowly increase the preseurs in 10 . pot increments to a maximum of $50 \mathrm{pol}$. Aftor each incremental increase of $10 \mathrm{p}$.1. If the preseurizing gas hes no' noved though the filter, and if no additioral llouid hes pasead through the filter in any 2-minute interval. proceed to the next 10-pol increment When the prescuriztrng ane begins to move through the filter, or when the liquid flow has ceased at 50 poi (l.e.. filtration does not result in any additional filtrute within a 2 -minute period). otop the filtration.

Noter Instantanoous applicstion of high presuure can degrade the glase llber filter and may cause premature plugedns.

8.8 The material in the fllter holdor is defineci as the solld plinese of the waste, and the filtrete is defined an the liquid phase. Weigh the flltrate. The llquid phase may now be elther anclyzed (See Step 8.12) or stored at $4^{\circ} \mathrm{C}$ until time of analyois.

Noter Some wastes, such as olly wastes and some paint wastes, will obviously contain eome muterial that appears to be a liquid. Even after applying vacuum or pressure filtration. outlined in Step 8.7, this matertal may not filter. If this is the case, the material within the filtration devicu is defired as a solid and is carried through the exiraction as a colld. Do not replace the original filter with a fresh filter under any ciroumstances. Use only one filter.

8.9 If the waste contains $<0.5$ percent dry solido (see Step 7.2), proceed to Step 8.13. If the waste contuine $>0.3$ percent dry solids (ros St 7.1 or 7.2), and if particle-bize sauction of the solid was needed in Step 7.3 procend to Step 8.10. If the waste as received passes a $9.8 \mathrm{~mm}$ sieve, quantitatively transfer the colid moterial into the extractor bottle along with the filier used to separate the initial liquid from the solid phase, and proceed to Step 0.11 .

a.20 Propare the solid portion of the waste for extrection by crushins cutting, or grinding the waste to a curfice area or particle-size as described in Step 7.3. When the surface area or purticle-size has been appiopriately aitered, quantitatively tranefer the solid material into en extractor bottle. Include the filter ueed to soparate the initial liquid from the colid phase.

Naten Sleving of the waste is not normally required. Surface arsa requirements are meant for flamentous (e.8. papar, cloth) and similar waste materials. Actual messurement of ourface aren is not recommended. If sleving is ncceseny, a Tallon-conted vieve should be used to avoid contamination of the nample.

8.11 Determine the emount of extraction fluid to add to the extractor vessel as follows:
Slowly add this amount of appropriate extraction fluid (see Step 7.4) to the extractor vessel. Close the extractor bottle tightly (it is recommended that Teflon tape be used to ensure a tight seal), secure in rotary agitation device, and rotate at $30+2 \mathrm{rpm}$ for $18+2$ hours. Ambient temperature (l.e., tersperature of room in which extraction (akes place) shall be maintained at $22+3^{\circ} \mathrm{C}$ during the extruction period.
$20 \times$ percent solids (Step 7.1) $\times$ weight of waste filtered (Step 0.5 or $\mathbf{8 . 7}$ ) filtering through a new gless fiber filler, as

Noto: As agitation continues, presoure may build up withis the axtractor bottle for some types of wastes (0.g. limed or calcium carbonate containing waste may evolve gases such as carbon dioxide). To relieve excese presaure, the extractor bottle may bo periodically opened (e.g., after 15 minutes, 30 minutes, and I hour) and vented into a hood.

8.12 Following the $18+2$ hour extraction separate the material in the extractor vesed into its component liquid and solid phases by outlined in Step a.7. For final filtration of the TCLP extract, the glese fiber filier may be changed. if necessary, to facilitate filtration. Filter(s) shall be acid-washed (see Step 4.4) if evaluating the mobility of metals.

8.13 Prepare the TCI.P extract as follows

8.13.1 If the waste contained no initial liquid phase, the filtered IIquid material obtained from Step 0.12 ls defined as the TCLP extract. Proct d to Slep 8.14. 
8.13.2 If competibly (e.8. muitiple phacese will not result on combination), combine the fillered liquid resulting from Stop. 8.12 with the laitial llquid phase of the waste obtained in Step 8.7. This combined liquid is defined as ihe TCLP extract, Proceed in SIUP 8.14.

8.13.J If the initial liquid phase of the waste, as obtained from Step 8.7. is not or inay not be compalible with the filtered liquid msuling from Step 8.12, do not combine these liquids. Anulyze these liquids. collectively unfined as the TCLP extract, and combine the rogults muthomatically, as !ngcribod in Siep 8.14.

8.14 Fullowing colleotion of the TCLP exiract, the $\mathrm{pH}$ nf the extruct stiould be recorded: Immedialely aliquot and presorve the extract for enulyuic Motuls aliquots must be acidified. with miturer acid to $\mathrm{pH}<2$. L precipilation lo obearved upon addition of nitrio acid to a small aliquot of the extraot. then the rearaining portion of the extrenct for metalo analyses shall not be acidufied and the exiract sbeil be andyesed as soon as posable. All other aliquate must be stored under refrigeration $\left(4^{\circ} \mathrm{C}\right)$. until analyzed. The TCLP extract thall be prepared and analyzed accurding to approprtate analytical methade. TCLP oxtrnots to be analyzed for matals shail te acid digested except in those instar. seal where digestion caunes loss of metullic contaminants. If an adalyate of the undigented extrect shows that the concentration of any regulated metalike contaminant exceede the regulatory lovel. then the waste is hazandous and digestion of the extract lo not neciesuary. However, date on undigested extracts alone cannop be usent. lo demonatrate that the waste is not. hazardous. If the individual phases are to be analyzed sepurately, determine the volume of the individual phases (to +0.5 percent). conduot the appropriate analyses, and combine the rusults mathematically by using a simpie volume-weighted average:
Finul anulytu concentration $=-\frac{\left(V_{1}\right)\left(C_{1}\right)+\left(V_{2}\right)\left(C_{2}\right)}{V_{1}+V_{2}}$
Charge the ZllE with sample unly uncse and du not open the device untll tho final oxtrast (of the solld) has been oollocted. Repeated filling of the $\mathrm{ZHE}$ to obtrin $2 \mathrm{~g}$ grams of solit in not permilted.

Do not allow the wuste, the initial Il puld phase. or the extrant to be expnsed to the atmosphere for any more lime than is ubolutely necessary. Any manipulatins of these malerials should bo done when rold it C) 10 minimize loes of volailley.

9.1 Pre-meing the (evecualed) fillinte collention container (SAe Sinp 4.0) and get aside. If using a TEDLAR^ bug exprese all liquid from the ZHE dovice Into the bHe whether for the initial or finul liquid/soljd separation. and take un ellipuot from the liquid in the bag for analy'sin. The contuinurs listed. in Step 4.6 ane reconimended for usn under the conditions slated in 4.1.1-1.6.3.

9.2 Place the ZREE pieton withia the boily of the 21 IE (it may be be! plul firct to inniyten the piston O-ringe slighily with extraction fluid). Adjust the piaton within the Z4 rE. borly to a boight that will minimize the diytunce the piaton will have 10 move ance the ZIFE is charged with ample (based upon sumple sizen requirements dolemined from Snction 8.10 . Stepp 7.1 and/or 7.2). Srecurn thre yon ialnt! oullul Nange (bottum flangt) onto the Zile budy in ancordance with the manufacturer'y instrictiona. Secure the glass fiber filter lostween the support screems and set asido. Sut lizuid inlet/outlet flange (top nange) aside.

9.J If the waste is 100 percent solid (nue Step 7.1), weigh out a subalumple (25 grum muximum) of the waste, record weight. und proveed to Step 9.5 .

9.4 If the waste contains $<0.5$ percent ury sulida (Step 7.2), the liquid portion of wasto. after filtrution is defined as the TCLP nxiract. Filter onough of the sample so thut the amount of filtered liquid will' support all of the volattle andysee required: For wastr. nuntaining > as percent dry sollds (Styps $i .1$ und/or 7.2), use the percent solids informution obtained in Step 7.1 to daterminu the upritnum asmple size to charge into the 7rIE. The misommended somple size is as linllowe:

11.4 .1 For wastes containing $<0.5$ purresst sulids (seo Slep 7.1), wolgh out 300 - gram sulbnimpit of wunte and record the waight. 8 t.2 for wustes containing >0.5 percent srillds ( wt:e Sinp 7.1), determine the umount if

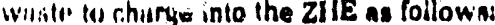
exiraclinn fluid equal 1020 limas the wingt of tho snllid phase.
Woighe of n.tate in thunge zHF
23 Ponsman sollidy IStenp ; 11
$110 n$
Weigh ust a subsample of the wasio of the ilupr:apridte size and record the woight. 9.3 If particle size iedisition of the eulid portion of the waste was ir quired in Stip 7.3 . procecd to Slep 8.6. If paricle esize reduction was not raquirid in Step 7.1. proscend to Step 9.7 .

9.8 Ire'pure the widste for exiructiur. by urushing. cu!l!ny, or yrinding the solid portiun of the waste to a enifuce aied or particle-Hize at doscribed in Slep 7.3.1. Wastns and appropitate reduction exulpment should be minfigerated, if possiblo, to 4 " $\mathrm{C}$ prior to

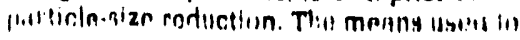

iffencl particle-size reduclionl . . ist nust gonerate heal in and of itself. If roduce:ion of the solid phase of the kaste in nociesnary. ixf yure of the waste to the utmonpham should bir acoided to the extenl prinsilite.

Note: Sleving of the winte is nul raconumended due to the possilhilly, it...1 vulutiles may be lost. The use of an upprupitutely graduated rulor is rucomminded as un accrutuble dltur nutivis. Surfacie area requirements $u: 2$ masn: for fllamentuus (u.g., paper, clull) and sinsilur waste materiale. Aritual measurument if murfuren uran is not recominentivit.
When the surfuce ares or partictu-sizu hist beun uperespriatoly altered, proceed to Sitep 4.7 .

9.7 Wasle slurrion aeed not be ullowed is

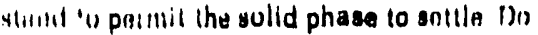
nill inirerifuge wasties prior to filtratiun.

H.il Ouuntitatively tranefer the ontiru

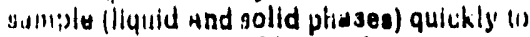
the $Z$ I IF. Suliuse the filter and support sereans unlus the top flange of the devitie ind vecure the lop funge to the $2 \mathrm{HE}$ body in Hcourdunce with the munufacturer's instivictions. Tighten all ZHE fittinge and nlui's the divirne in tha vertical position l'ans 
Inlet/outlet llange on the bottom). Do not attuch the extract collection device to the top plate.

Noter If waste matertul ( $>1 \%$ of original sample weight) has obviously adhered to the container used to tranofer the sample to the ZHIE, determine the weight of this residue and subtract it from the eample weight determined in Step 9.4 to determine the weight of the waste sample that will be fllered.

Alluch a gas line to the gas inlet/outlet valve (bottom nange) and, with the liquid inlet/outlet valve (top flange) open, bogin applying genile presuce of 1-10 pal (or more if nenessary) to force all headopace slowiy out of the ZHIE device into a hood. At the first appearance of liquid from the liquid inlet/ outlel valve, quickly close the valve and discontinus preseure. If filtretion of the waste at 4 'C reduces the amount of expressed liquid over what would be expressed at room temperature, then allow the sample to warm up lo room temperature in the device before filtering. If the waste le 100 percent solid (eev Step 7.1). Jlowly increace the presuure to maximum of 80 pal to force most of the headspace out of the device and proceed to Stop 0.12

9.8 Attach the evacuated pre-woighed filtratu collection container to the llquid inlet/outlet valve and open the valve. Begin applying gentle preseure of $1-10$ poi to force the liquid phase of the sample into the filtrate collection container. If no edditional liquid hes passed through the filter in any 2-minute interval. slowly increave the presoure in 10pal increments to maximum of 50 pal. After each incremental incresece of 10 psl, if no additional liquid has pased through the nlter in any $2 \cdot$ minute interval, proceed to the next 10.poi increment. When liquid flow has ceased sucil that continued pressure filtration at 50 pal does not result in any additionai nitrate within a 2 -minute period stop the filtration. Close the liquid inlet/outlet valve. discontinue presoure to the piston and disconnect and weigh the filtrate cullection container.
Note Inatantaneous application of high proveure can degrade the glawe fiber filter and mey cause premature plugging.

9.10 The material in the ZHE to defined as the solid phese of the waste and the filtrele is defined as the liquid phase.

Note: Some wastes, such as oily wastes and some paint wastes, will obviously contain some material that appears to be liquid. Even after applying preseure filtration. this material will not filter, If this is the case. the matertal within the filiration devioe is defined as a colid ad is carried through the TChP extraction an colid.

If the original waste contained $<0.5$ percent dry solide (see Slep 7,2), this filtrale is defined os the TCLP extract and is analyzed directly. Proceed to Step 8.15,

9.11 The liquid phase may now be elther analyzed immediately (See Steps 9.13 through 0.15 ) or stored at $4^{\circ} \mathrm{C}$ under minimal headspace conditions until lime of analysis. Determine the weight of extraction nuid $* 1$ to add to the ZHE as follows:
9.12 The following steps dolall how to add the appropriate amount of extraction nuid to the solid material within the $\mathrm{ZHE}$ and agitation of the ZHE ressel. Extraction nuid $=1$ is used in all cases (See Siep 5,0).

9.12.2 With the $\mathrm{ZHE}$ in the vertical position. altach a line from the extraction nuid reservoir to the liquid inlet/outlet valve. The line used shall contain fresh extraction fluid and should be preflushed with fluid to climinale any air pockets in the line. Release gas pressure on the ZHE piston (from the gas inlet/outlet valve), open the liquid inlet/ outlet valve, and begin tranaferring extraction nuld (by pumping or similar means) into the ZHIE. Continue pumping extraction fluld into the ZHE until the appropriate amount of fluid has been introduced into the dovice.

9.12.2 After the extraction nuid hes been idded. immediately close the liquid inlet/ outlet valve and disconnect the extraction nuld line. Check the ZHE to onsure that all vulves are in their cloeed positions. Manually rutato the device in an end-over.end fashion 2 or 3 times. Reposition the ZIIE in tise inrticui position with the liquid inlet/outlet valie on top. Pressurize the ZHE to s-10 pai (if necessary) and slowly open the liquid inlet/outlet valve to bleed out any headepaco (inlo hood) that may have been introduced due 10 the addition of extraction fluid. This
Ulueding shall be done quickly and shall be stopped at the first appearance of liquid from the valve. Re-pressurize the ZHE with o-10 pai and check all ZHE fittings to ensure that they are closed.

9.12.3 Place the ZHE in the rotary agitution apparatus (if if is not already there) and rotale al $30+2 \mathrm{rmm}$ for $18+2$ hours. Ambient lemperature (i.e.i. lemperature of room in which extraction occura) shall be maintained at $22+3^{\circ} \mathrm{C}$ during agitation.

9.13 Pollowing the $18+2$ hour agitation period. check the prassure behind the $\mathrm{ZHE}$ piaton by quickly opening and closing the gus inlet/outlel valve and nuting the escape of 8as. If the presoure has not been maintuined (1.e., no gas release observed). the devire is leuking. Check the ZHE for louking as snecified in Step 4.2.1, and perform the extraction again with a new sample of waste. If the presesure within the device has been maintained the material in the extrector vessed is once again separated into its component liquid and solid phases. If the waste contained an initial liquid phase, the liquid may be fillered directly into the same filirate collection container (l.e. TEDLAR" bag) holding the initial liquid phase of the waste. A separate filtrate collection contuinor must be used if combining would create multiple phases. or there is not enough volume left within the filtrate colluction contuiner. Filter through the glass fiber filter. using the ZHE device as discussed in Slep 9.9. All extract shall be filtered and collecled If the TEDLAR' bag is used. If the extract is multiphasic, or if the wuote contained an initial llquid phase (eee Sieps 4.6 and 9.1).

Note: An in-line glase fiber filter may be used to filter the material within the ZFIE if II in suspected that the glase fiber filter has been ruptured.

9.14 If the original waste contained no initial liquid phase, the filtered liquid material obinined from atep 9.13 is defined as the TCLP extract. If the wasle contained an initial liquid phase, the filtered liquid material obtained from Step 9.13 and the Inittal liquid phase (Step 9.9) ure collectively defined os the TCLP extract.

8.15 Following collection of the TCLP extract. immediately prepare the extract for analyais and store with minimal headspace ut $4{ }^{\circ} \mathrm{C}$ until analyzed. Analyze the TCLP extract according to the appropriale analytical methoda. If the individual phases are to be anaiyzed separately (i.e.. are not miscible). delermine the volume of the individual phaces $(100.5 \%)$, conduct the appropriale analyees. and combine the resulte mathematically by using a simple volume. weighted average:

$$
\text { Pinal analyte concentration } \frac{\left(V_{1}\right)\left(C_{1}\right)+\left(V_{2}\right)\left(C_{1}\right)}{V_{1}+V_{2}}
$$

[Appendix II] 
where:

$V_{1}=$ The volume of the firnt phases (I).

$C_{1}=$ The concentration of the contaminant of concern in the first phen $(\mathrm{m} / \mathrm{l})$.

$V_{2}=$ The volume of the socond phese (1).

$C_{2}=$ The concentration of the conteminant of concern in the eecond phase ( $\mathrm{mg} / \mathrm{ll}$ ).

9.16 Compare the contaminant

concentrations in the TCLP extract with the thresholds identified in the appropriate regulations. Refer 10 section 10.0 for quality assurance requirements.

\subsection{Quality Assurance Requirements}

10.1 Maintain all date including quality assurance data, and keep it availabis for reference or inspection.

10.2 A minimum of one blank (extraction nuid $=1$ ) for every 10 extractionn that have been conducted in an extraction vessel shall be employed a a check to determine if any memory offects from the extraction equipment are occurring.

10.3 A matrix apike thall be performed for each waste uninins tho result exceeds the regulatory level and the data is being ueed solely to demonstrate that the waste property exceede the regulatory level. If more than one sample of the same waste is teing tested. a matrix spike needs to be performed for every twenty samples and the everage percent recovery anplied to the waste characterizotion.

10.3.1 Matrix spikes an to be added after filtration of the TCLP exirect and before preservation. Matrix spikes should not be added prior to TCLP extraction of the sample.

10.3.2 Matrix spike levels should be mede at the appropricte regulatory threchold limits. Howover, if the extract conteminant concentration is lees than one half the threshold limit, the opike level may be one half the contaminant concentration but not less than the quantitation limit or fifth of the threshold limit.

10.3.3 The purpose of the matrix spike is to monitor the adequacy of the analytical methode used on the TCLP extract and to deterianine whether matrix interferences exist in analyte detection. If the matrix apike recoveries an lose than 50x, then the analytical mithods are not performing adequately use of the methods is inadequate. Use of intermal calibration quantitation methods. modification of the anelytical minhods, of use of alternate analytical methode may be alded to accurately measure the contaminant concentration in the TCLP extract.

10.3.4 Use of intemal quantitation methoda is aleo required when the contaminant concentration is within $20 \%$ of the regulatory level. (See section 10.5 concerning the use of intermal calibration methods.)

10.3.5 Matrix spike recoveries are calculated by the following formula:

$$
\text { Percent recovery }=\frac{A-B}{C} \times 100 x
$$

where $A=$ the concentration of the spiked sample.

$B=$ the concentration of the unspiked sample. and

$\mathrm{C}=$ the spike level

10.4 All quality control measures described in the appropriate analytical methode shall be followed.

10.5 The use of intemal calibration quentitation methods shall be employed for a contaminant if: (1) Recovery of the contaminant from the TCLP extract is not at least 50\% and the concentration doen nol exceed the regulatory level. and (2) The concentration of the contaminant measured in the extract is within $20 \%$ of the appropriste regulatory level.

10.5.1 The method of etendard additione shall be employed ae the internal calibration quantitation mothod for each metallic contaminant.

10.3.1.1 The methoct of olandard additions requires preparing calibration atandards in the eample matrix rather then reagent water or blank colution. It requires taking four identical aliquots of the solution und adding known emounts of atandard to three of these aliquote. The fourth aliquol io the unknown. Preferably, the first addition should be prepared so that the resulting concentration is approximately $50 \%$ of the expected concentration of the eample. The second and third additione should be prepared 20 that the concentratione are approximately $100 \%$ and

$150 \%$ of the expected concentration of the cample. All four aliquots are maintained at the same final volumo by adding reagent water or a blank soluiton, and may nead dilution adjustment to maintain the signals in the lineor range of the instrumental

technique. All four aliquots ure analyzed.

10.5.1.2 Prepare e plot, or aubject data to linear regresoion. of inutrumental signals or external-aslibration-derived concentration as the deperident variable (y-axio) versue concentrations of the additions of standard as the independent variable $(x$-axis). Solve for the int rcept of the absciers (the independent variable, $x$-axis) which is the concentration in the unknown

10.5.1.3 Altemately, subtract the instrumental signal or external-calibration. derived concentration of the unknown (unspiked) eample from the instrumental oignals or external-calibration-derived concentrations of the atandard additions. Plot or subject dete to linear regresaion of the corrected instrumental oignals or external. calibration-derived concentrations ae the dependent variable versus the independent variable. Dorive concentrations for unknorvns using the internal calibretion curve as if it were en external calibration curve.

10.0 Sampleo must underso TCLP extraction within the following time periods:

SAMPLE Maximum Holoino Times

toayel

\begin{tabular}{|c|c|c|c|c|}
\hline & $\begin{array}{l}\text { From: } \\
\text { Field collection } \\
\text { To: } \\
\text { TCLe extrection }\end{array}$ & $\begin{array}{c}\text { From: } \\
\text { TCLP oxtraction } \\
\text { To: } \\
\text { Preperatve extrection }\end{array}$ & $\begin{array}{c}\text { From: } \\
\text { Preperative extraction } \\
\text { To: } \\
\text { Deteminative enuryos }\end{array}$ & Total elapeed lime \\
\hline 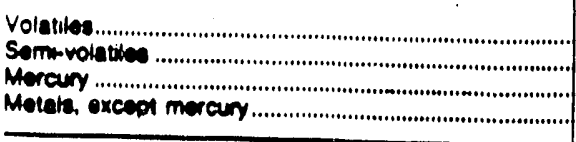 & $\begin{array}{r}14 \\
7 \\
20 \\
100\end{array}$ & $\begin{array}{c}\text { NA } \\
7 \\
\text { NA } \\
\text { NA }\end{array}$ & $\begin{array}{r}14 \\
40 \\
28 \\
180\end{array}$ & $\begin{array}{r}28 \\
54 \\
56 \\
360\end{array}$ \\
\hline
\end{tabular}

If sample holding times are exceeded, the values obtained will be considered minimal concentrations. Exceeding the holding time is not acceptuble in establishing that a waste does not exceed the regulatory level. Exceeding the holding time will not invalidate characterization if the waste ex. ceeds the regulatory level. 


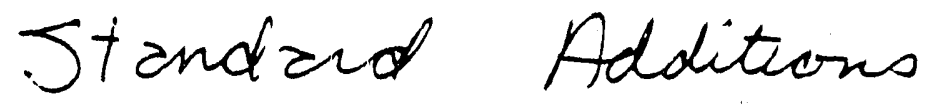

ind particularly the higher aosorption values are nitore closely spaced. This presentation closely imitates the logarithmic response of the atomic absorption spectrophotometer as it appears on the strip-chart of a recorder. Concentration values obtained between $60 \%$ and $70 \%$ absorption are considerably more difficult to resolve than those between $10 \%$ to $20 \%$ or $30 \%$ absorption.

Any of the;e calibration curves can be used for the purpose of estimating calcium in serum because only a small segment of each curve is needed to contain the entire range of the normal values, as well as most abnormally low or high concentrations. This segment of the curve is shown in expanded form in figure $6-11$. The concentration scale is in apparent units-equivalent to 50 times the true concentration--in order to present a direct result. The response of the instrument is given in \% absorption as obtained on the strip-chart recorder. Note that the calibration function is nearly a straight line between concentrations of 5 and 12.5 $\mu \mathrm{g} / 100 \mathrm{ml}$. Because of this property, the unknown concentration may be entered into the working curve as \% absorption rather ihan absorbance, thereby eliminating the need to transpose absorption into absorbance. (This transposition is sumbersome, and should be avoided when analytical conditions permit.) Results of comparable accuracy and precision are obtained by using either direct $\%$ absorption readings on a linear plot (figure 6-9, curve A), or \% absorption plotted against concentration on a log-log scale (figure $6-10$ ), or transposing \% absorption to absorbance (figure 6-9, curve B).

Similar working curves and the same general approach also apply to the determination of $\mathrm{Na}$, $\mathrm{K}$, and $\mathrm{Mg}$ in serum, urine and other fluids with predictable and relatively narrow concentration ranges.

\section{- METHOD OF STANDARD ADDITIONS}

The determination of an unknown concentration by the method of standard additions is used in several instrumental procedures including atomic absorption spectroscopy. In clinical chemistry, this method has limited application and does not usually serve as a basis for routine analysis. Its chief usefulness is in those determinations where appropriate comparative standard solutions are not readily available, or where more accurate methods have not been worked out or are unknown to the analyst. The principal advantage of this method is that, within certain concentration limits, it is self- compensatory for various interferences which may not be measurable and need not be known or corrected for.

WThe standard additions technique is an extrapolative measurement based on two assumptions:

(1) That the working curve is linear or predictable and remains so within the concentration range of the analysis;

(2) That a known amount of a metal added to the specimen will behave, in a spectrochemical sense, in a manner similar to the naturally bound metal in the native tissue.

Both assumptions may be correct only in relation to certain elements, in near-aqueous or aqueous solutions, and within relatively narrow concentration limits.

\section{The Procedure:}

(a) Estimate (or test) the concentration of the element under analysis to determine the approximate instrument range at which the analysis should be performed. (You must know whether to dilute, concentrate, or analyze the specimen "as-is" in its native state.)

(b) From the original specimen withdraw at least 2 (and preferably 3 ) equal aliquots, and transfer these to volumetric flasks of the same volume. The flasks should be only partially filied.

(c) To aliquot $\neq 1$, add water to volume.

(d) To aliquot $\$ 2$, add about $25 \%$ of the estimated amount of the element under analysis (step a).

(a) To aliquot \#3, add abcut $50 \%$ of the amount originally estimated (step al. Additional aliquots may be used, each containing an increasingly larger quantity of the element under analysis. Be sure the final volume or weight of all the aliquots is the same.

(f) Regardless of the samfic preparation method used prior to analysis (dilitior. concentration, extraction, etc.), treat all aliquets of the specimen in exactly the same manner.

(g) Aspirate the original specimen (aliquot $\neq 1$ ) and the additional aliquots, excn cuntaining a known added amount, and record the sbsorption signal. Convert \% absorption to absorbinis:

(h) The concentration of the unknown can be calculated or it can be determined graphically as shown in figure 6-12. This working curve is based on linear proportionality between concentration and absorbance. Therefore, the concentration of the .mknown (x) is proportional to its absorbance $A_{x}$ 
is the concentration of the unknown ( $x$ ) plus the added amount $\left(a_{1}\right)$ is proportional to its absorbance, $A_{1}$.

Or (equation 1) $X=\frac{a_{1} A_{x}}{A_{1}-A_{x}}$

Note: $a_{1}$ is known; $A_{x}$ and $A_{1}$ are measured.

(i) When more than a single "added amount" is used, the additional valuas may serve to verify the assumption that the wurking curve is indeed linear. In accordance with equation I, the calculated concentration of the unknown ( $x$ ) should be the same regardless which aliquots $(\# 2, \# 3$, or others) are used in its determination.

(j) The graphic presentation (figure 6-12) is frequently more convenient in verifying the linearity of the working curve. Note that the concentration of the unknown is determined at the intercept of the zero-absorbance axis and a line drawn through points $A_{x}, A_{1}, A_{2}$ etc. The units of concentration used in measuring the added values also establish the concentration of the unknown.

(k) For best results, the added quantities should be fairly close to the true concentration. Additions of from $1 / 4$ to twice the originally estimated amount are suitable for most clinical analyses, within the general limitations of this method.

\section{Problem:}

Determine an unknown concentration of calcium in an aqueous solution. (Note: the values obtained below represent the actual readings in this experiment.)

\section{Step 1}

With the AA instrument programmed for calcium, the unknown specimen was aspirated. The resulting signal of about $13 \%$ absorption was estimated (from the typical calcium calibration curve in figure 6-1) to represent a concentration of over $2 \mu \mathrm{g} / \mathrm{ml}$ but no more than $5 \mu \mathrm{g} / \mathrm{ml}$ (say $3 \mu \mathrm{g} / \mathrm{ml}$ ). Aliquots of $5 \mathrm{ml}$ of this unknown solution were added to each of four $10-\mathrm{ml}$ volumetric flasks.

\section{Step 2}

(a) To aliquot $\neq 1$, water was added to volume, resulting in a $1: 2$ dilution.

(b) To aliquot $\# 2,1 \mathrm{ml}$ of a $2 \mu \mathrm{g} / \mathrm{ml}$ aqueous calcium standard was added. The volumetric flask was filled to volume with water. (Added amount: $a_{1}=0.2 \mu \mathrm{g} / \mathrm{ml}$ of $\mathrm{Ca}$ )

(c) To aliquot $\# 3,2 \mathrm{ml}$ of a $2 \mu \mathrm{g} / \mathrm{ml}$ Ca standard were added and made up to volume. (Added amount: $\mathrm{a}_{2}=0.4 \mu \mathrm{g} / \mathrm{ml}$ )

(d) To aliquot \#4,5 $\mathrm{ml}$ of a $2 \mu \mathrm{g} / \mathrm{ml} \mathrm{Ca}$ standard were added. This filled the volumetric flask to volume. (Added amount: $a_{3}=1.9 \mu \mathrm{g} / \mathrm{ml}$ )

\section{Step 3}

All 4 aliquots were aspirated, and the \% absorption measured and transposed to absorbance. The data was plotted as shown in figure 6-12. The following results were obtained:

Aliquot no
1
2
3
4

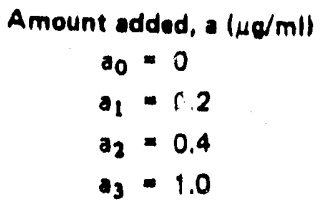

\section{Step 4}

Concentration was determined from equation 1.

$$
\mathrm{X}=\frac{0.2 \times 0.065}{0.076-0.065}=1.18
$$

This value is multiplied by 2 because of the previous $1: 2$ dilution (step 2).

$$
1.18 \times 2=2.36 \mu \mathrm{g} / \mathrm{m} !
$$

\section{Step 5}

From figure 6-13, the concentration of the unknown was obtained graphically by connecting points $A_{x}$, $A_{1}, A_{2}, A_{3}$, through the intercept of the zero absorbance line. The value thus obtained was $1.22 \times 2=2.44 \mu \mathrm{g} / \mathrm{ml}$. Note that point $A_{3}$ fell below the straight line that connected $A_{x}, A_{1}$, and $A_{2}$.

\section{Step 6}

The unknown concentration was also calculated on the basis of each "added amount" separately as follows:

$$
\begin{aligned}
& a_{2} A_{2} \text {, added amount } 0.4 \sim g_{1}^{\prime} \mathrm{ml} \text {. } \\
& \text { (eq. 1) } X=\frac{0.4 \times 0.065}{0.087 \cdot 0.065}=1.18: 1.18 \times 2= \\
& 2.36 \mu \mathrm{g} / \mathrm{ml} \text { (answer) }
\end{aligned}
$$

$$
\mathrm{a}_{3} \mathrm{~A}_{3} \text {, added amount } 1.0 \mu \mathrm{g} / \mathrm{ml} \text {. }
$$

(eq. 1) $\mathrm{X}=\frac{1.0 \times 0.065}{0.115 \cdot 0.065}=1.3: 1.3 \times 2=$

\section{$2.6 \mu \mathrm{g} / \mathrm{ml}$ (answer)}


The results obtained on the basis of the last vaiue $\left(a_{3} A_{3}\right)$ differed from the previous value by about $+10 \%$. This confirmed that the callbration curve could not be extrapolated to point $A_{3}$ which departed from the expected linear proportionality between concentration and absorbance.

'The concentrution of the unknown was found to be $2.40 \mathrm{pym} \pm S D$ (stundard deviation) 0.008 ppm on the bssis is? ..tintuplicate analysis by conventional inturfution between the closely spaced standurs suiw uns of 2.0 and $3.0 \mathrm{ppm}$.

The method ol sidadard additions is prone to error because of possible inaccurate reading of \% absorption or absorbunce - much more so than the con'entional interpolutive techniques. For example, assume that the absorbance at Point $A_{x}$ was read as 0.063 ins:egd of 0.065 .

The difference beinton these readings is equivalent to about : to 3 times the thickness of the stylus line of $i$ in recorder. The error that would result had the concentration of the unknown been obiared by wenventional methods would be about 3 . However, in the method of standard additions, the error would be far greater, since the proportionality lactors which apply to equation I (arithmetically or graphically) are very sensitive to $A_{x}$, the absorbance of the unknown. To illustrate: if $A_{\lambda}$ was read as 0.63 and a single added value of $0.2 \mathrm{ppm}\left(a_{1} A_{1}\right)$ used in computing the unknown, then:

(eq. 1) $X=\frac{0.2 \times 0.063}{0.076-0.063}=0.97 \mathrm{ppm}$

$$
0.97 x^{\prime} 2=1.94 \mathrm{ppm}
$$

The difference between this and the "true" value is:

$$
2.40-1.94=0.46 \mathrm{ppm} \text { or } i 9 \%(!) \text {. }
$$

Points $A_{2}$ and $A_{3}$ would yield similar errors.

What we can conclude from all this is that the analyst should experiment with the method of standard additions before applying it to important analytical problems, in order to become fully aware of its advantages and its limitations. It should be considered an emergency procedure only. Analytical routines are usually not based on it. 


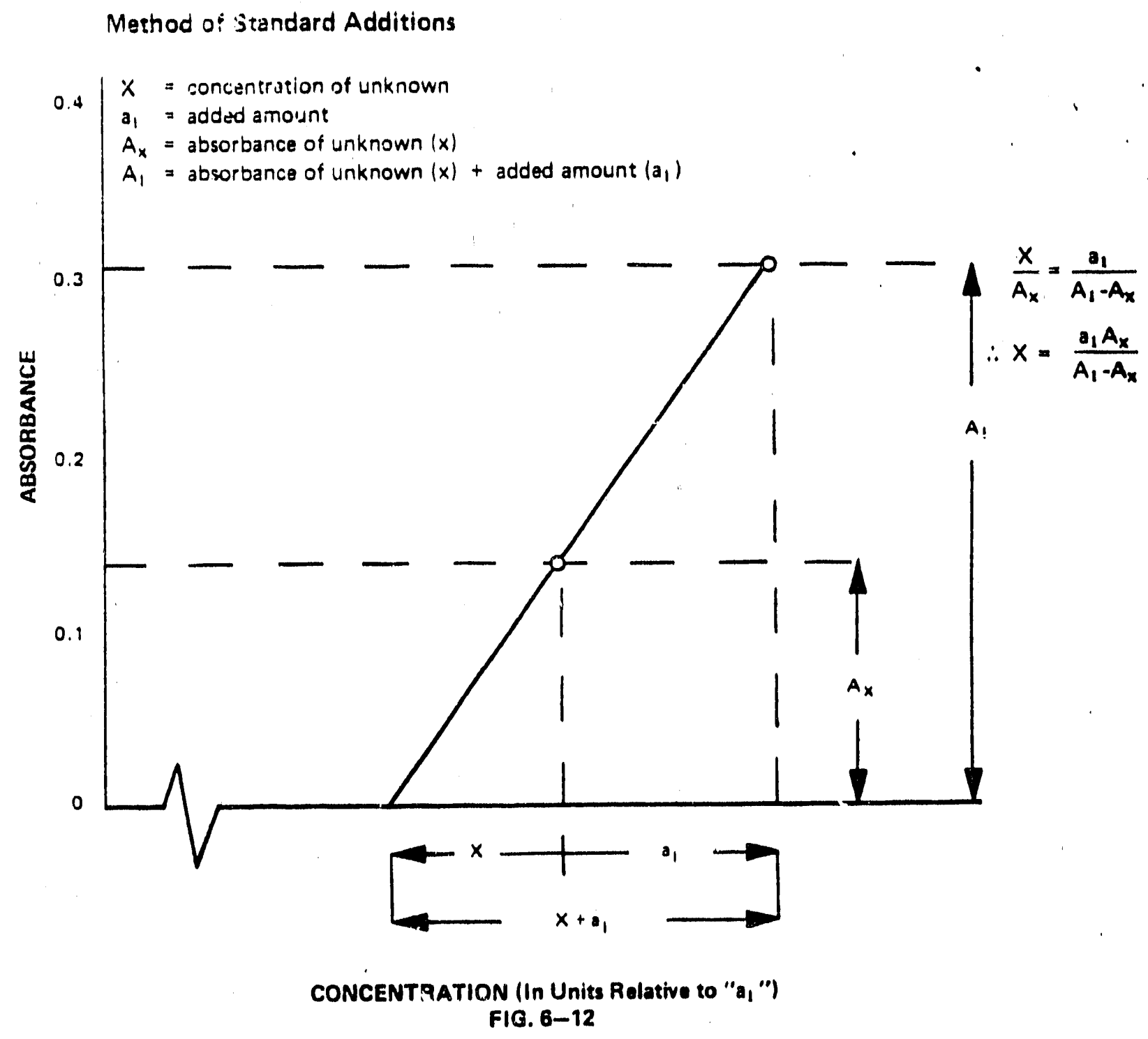




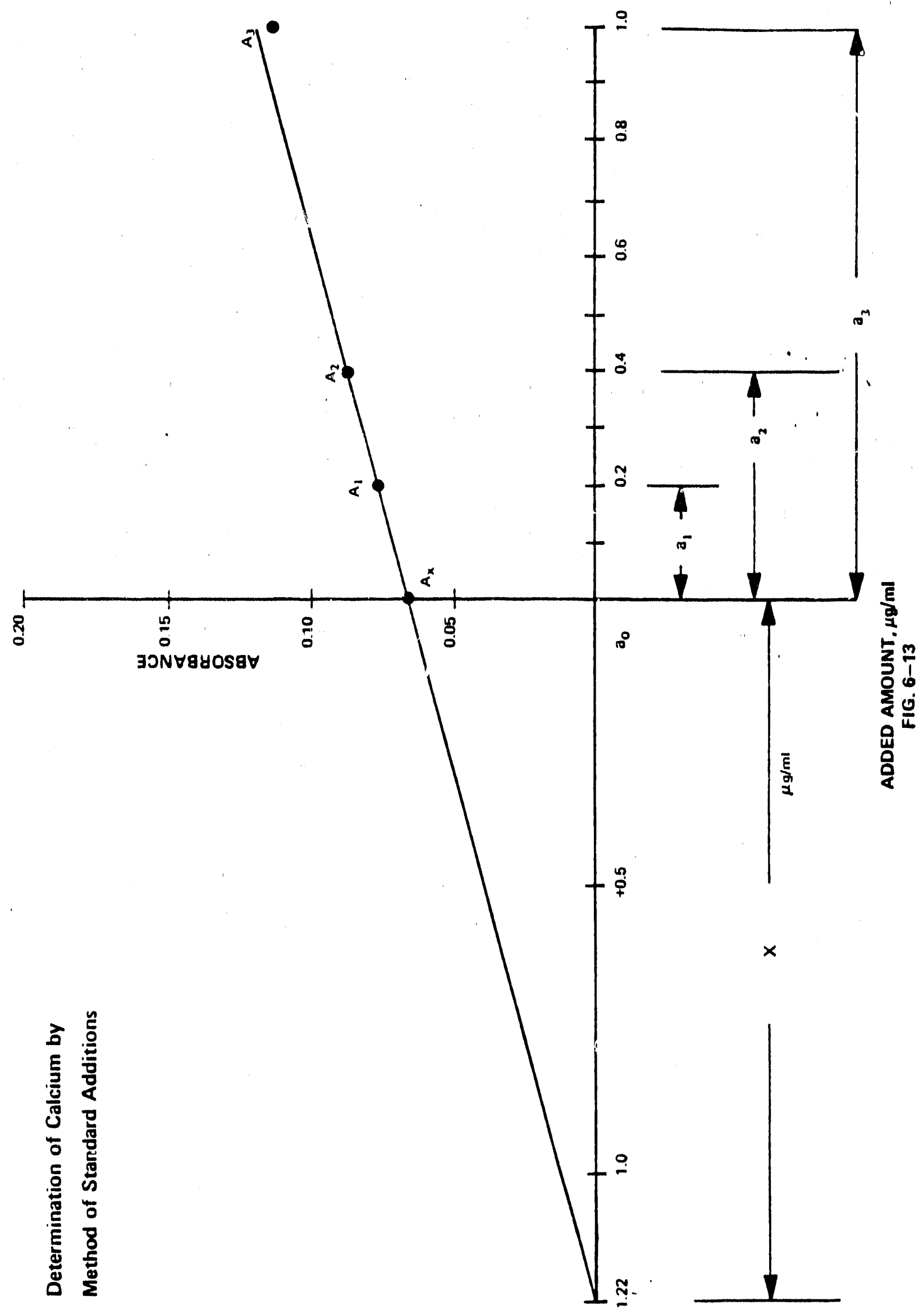

E-27 
Analytical Report

03/15/91

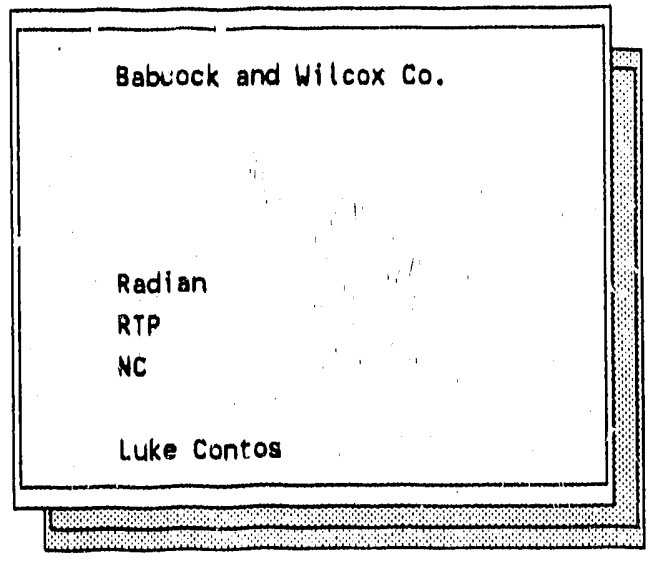

Customer work Identification LIMB PROJECT

Purchase Order Number 209-026-05-00

Contents:

Analytical Data Summary

Sample History

Comments Summary

Notes and Definitions

Radian Analyicical Services

8501 Mo-Pac Boulevard

P. O. Eox 201088

Aust in, TX 78720-1088

$512 / 454-4797$

Cliant Services Coordinator: KAYOUNG

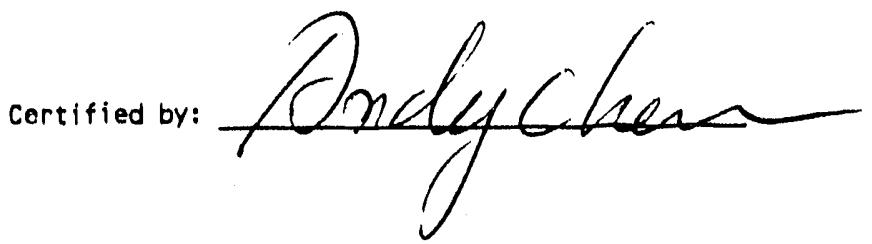

F-1 
Babcock and Wilcox Co.

Radian Work Order: 91-02-047

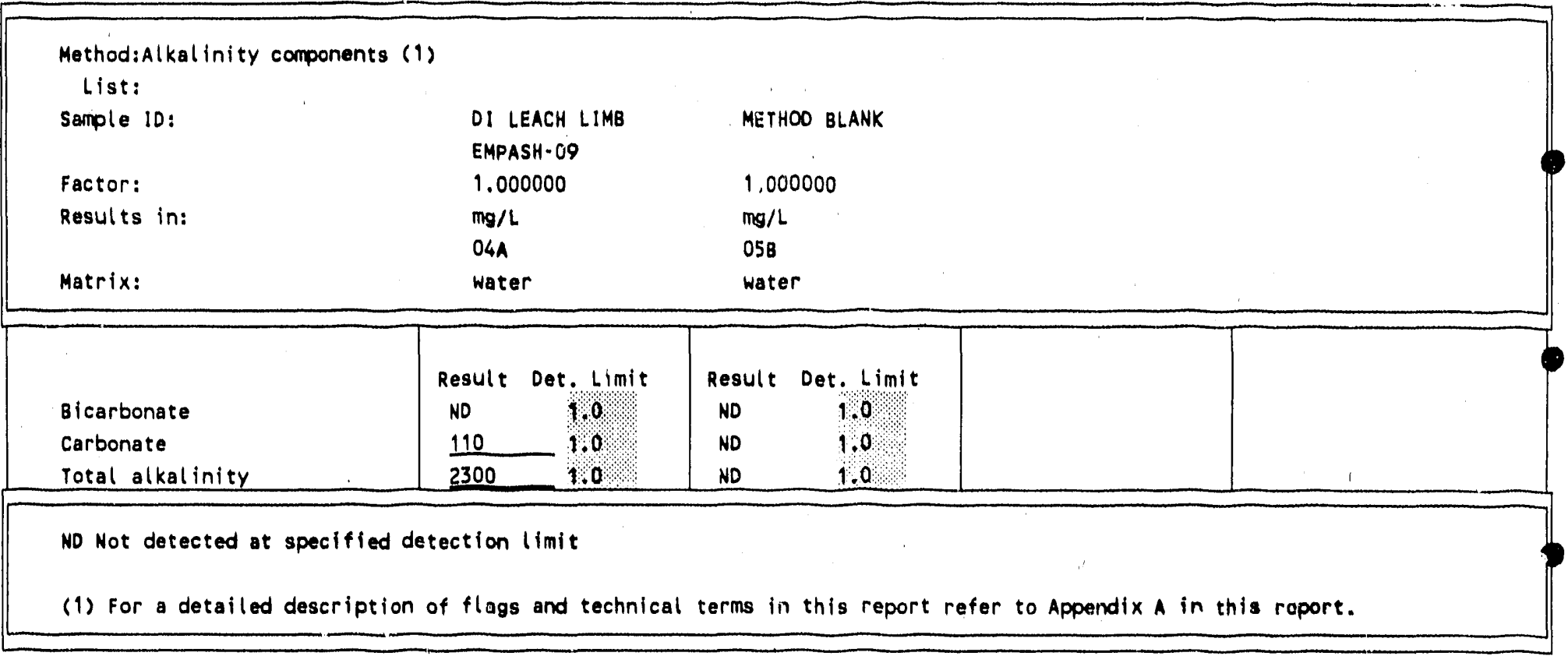


Babcock and Wilcox Co.

Radian Work Order: 91-02-047

Method: ICi 25 element scan SH6010 (1)

List:ICP, TCLP MS

sample 10:

TCLP LEACH LI.

TCLP BLANK

METHOO BLANK MB EMPASH-08

Factor:

Results in:

\section{1}

$\mathrm{mg} / \mathrm{L}$

02A

Matrix:

water

1

$\mathrm{mg} / \mathrm{L} \quad \mathrm{mg} / \mathrm{L}$

038

water $\mathrm{mg} / \mathrm{L}$

05A

water

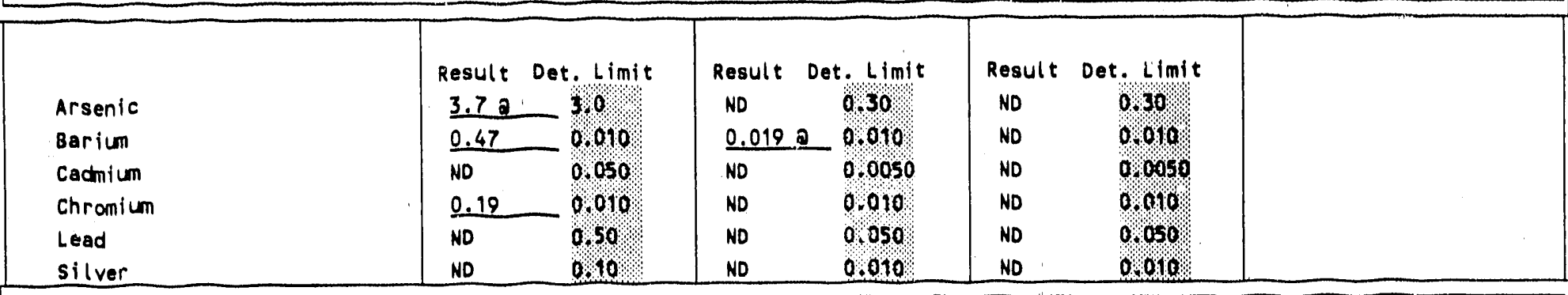

Dst. result less that 5 times detection limit

ND Not detected at specified detection limit

(1) For a detailed description of flags and technical terms in this report refer to Appendix $A$ in this report. 
Babcock and Wilcox Co.

Radian Work Order: 91.02.047

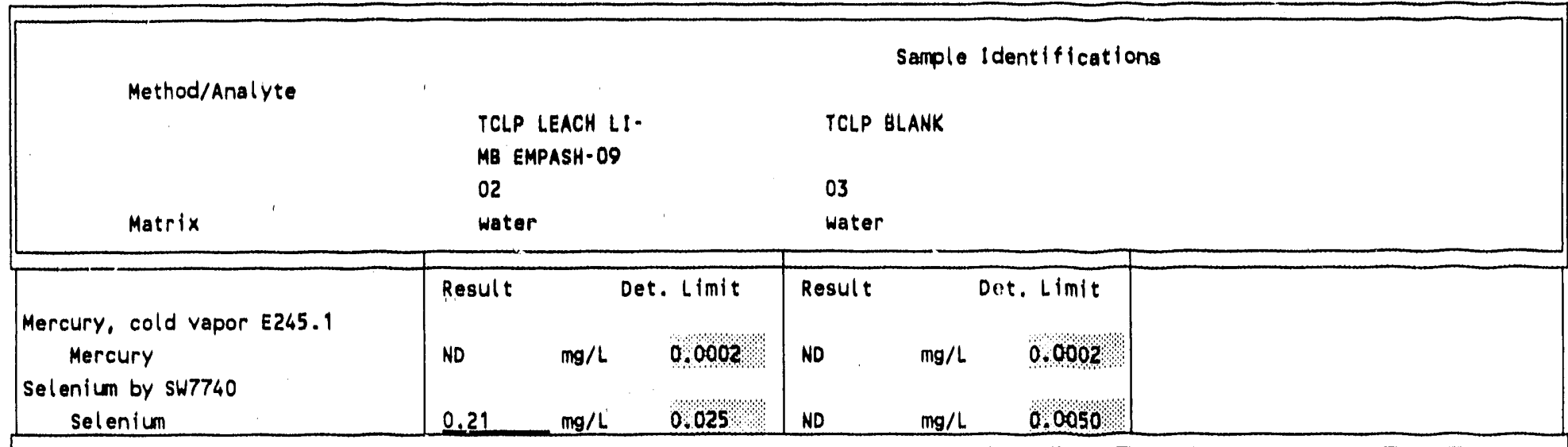

ND Not detected at specified detection limit

(1) For a detailed description of flags and technical terms in this report refer to the glassary. 
Babcock and Wilcox Co.

Radian Work Order: 91-02-047

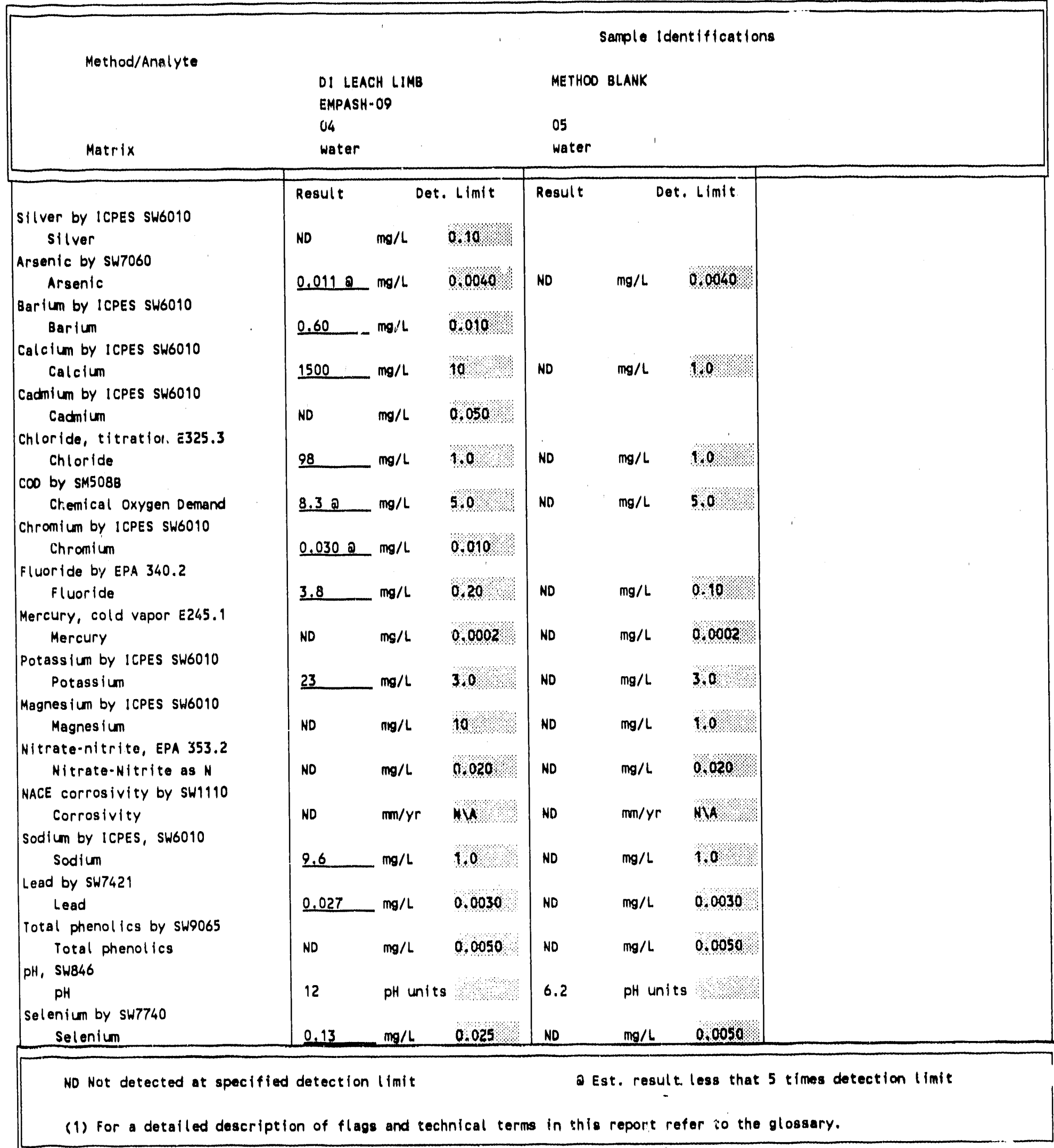


Babcock and Wilcox Co.

Radian Work Order: 91.02-047

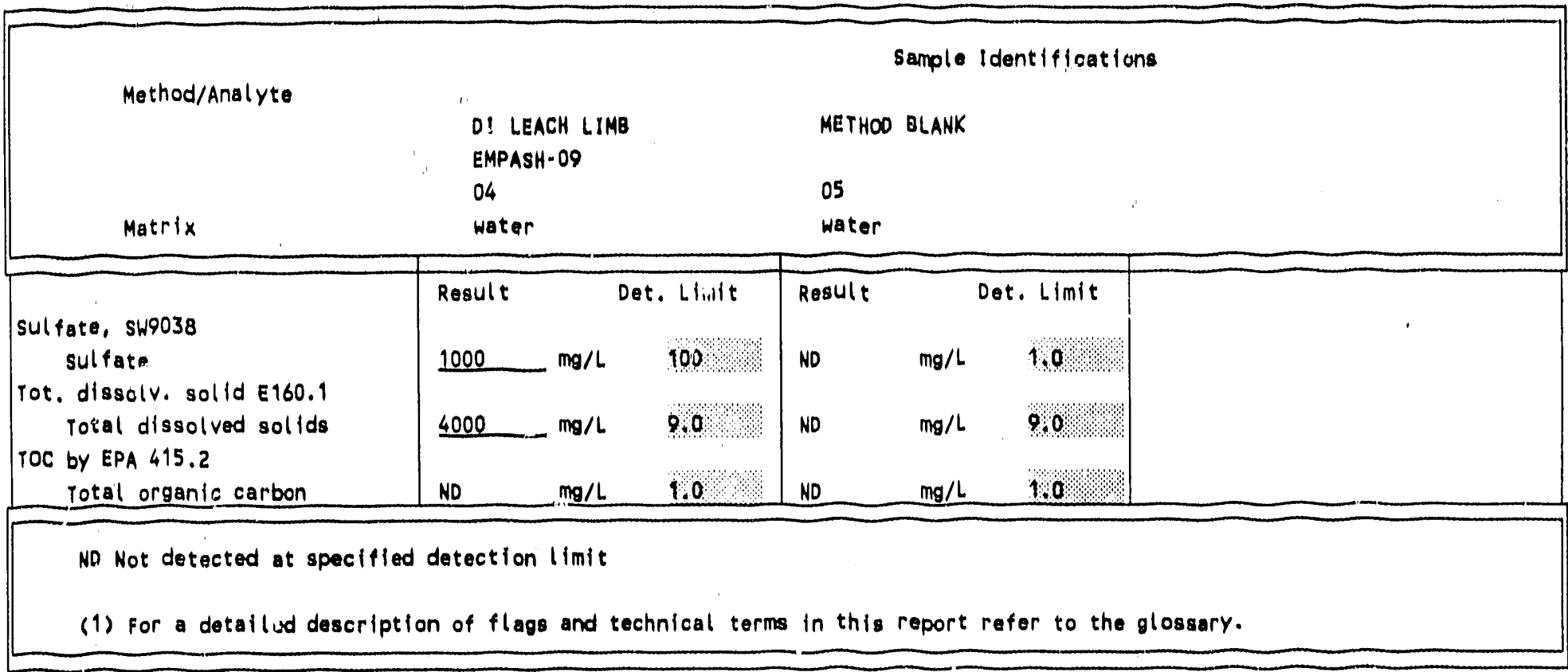


Babcock and Wilcox co.

Radian Work Order: 91-02-047

Sample Identifications and Datca

Sample 10

Date Received

Matrix
LIMB EMPASH-09 TCLP LEACH L1- TCLP BLANK

MB EMPASH 09

$02 / 05 / 91 \quad 02 / 11 / 91$

$02 / 06 / 91$

$02 / 06 / 91$

02

01

Sllver by ICPES SW6010
Prepared
Analyzed
Ana!yst
Flle 10
Blank 10
Instrument
Report as

Alkal inity components

Prepared

Analyzed

Analyst

File 10

Blank 10

Instrument

Report as

Arsenic by SW7060

Prepared

Analyzed

Analyst

file 10

$B$ lank 10

Instrument

Report as

Barium by ICPES SW6010

Prepared

Analyzed

Analyst

File 10

Blank ID

Instrument

Report as

Calcium by ICPES SW6010

Prepared

Analyzed

Analyst

File 10

Blank 10

Instrument

Report as

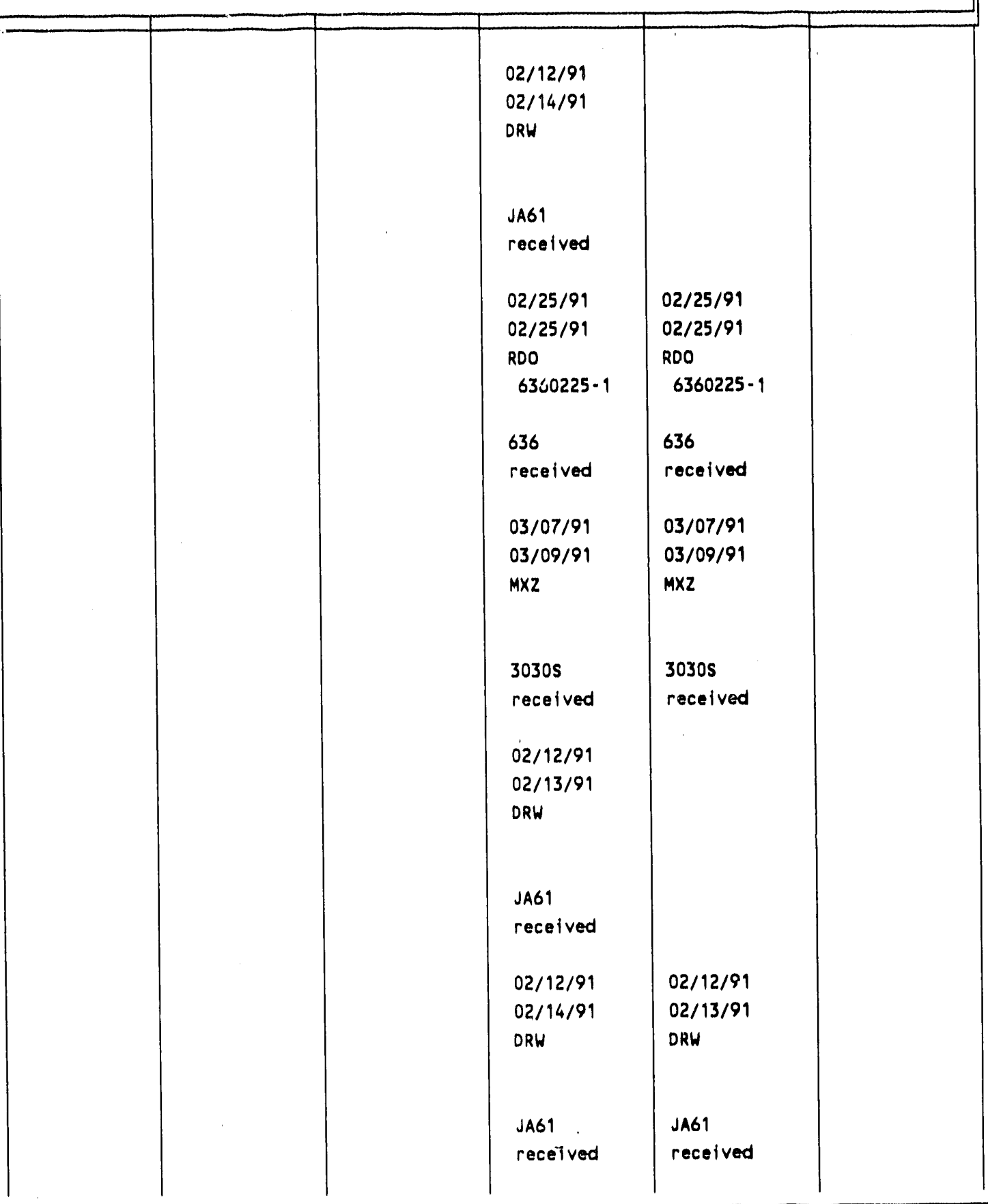

DI LEACH LIMB METHOD BLANK

EMPASH-09

$02 / 11 / 91$

02/06/91 02/06/91

water water

$04 \quad 05$

JAG

$02 / 25 / 91$

RDO

6360225 -

636

$03 / 07 / 91$

$03 / 07 / 91$

03/09/91

$M \times 2$

$3030 \mathrm{~S}$

$02 / 12 / 91$

$02 / 13 / 91$

RW

JA61

$02 / 12 / 91$

$02 / 13 / 91$

$02 / 14 / 9$

JA61 
Babcock and Wilcox Co.

Radian Work Order: 91.02.047

Sample Identifications and Dates

Sample ID

Date Sampled

Date Received

Matrix

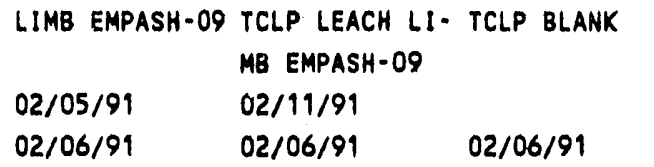

02

03

01

3

$\begin{array}{ll}\text { DI LEACH LIMB } & \text { METHOD BLANK } \\ \text { EMPASH-09 } & \\ 02 / 11 / 91 & \\ 02 / 06 / 91 & 02 / 06 / 91 \\ \text { water } & \text { water } \\ 04 & 05\end{array}$

Cadmium by ICPES SW6010

Prepared

Analyzed

Analyst

File 10

Blank ID

Instrument

Report as

04

05

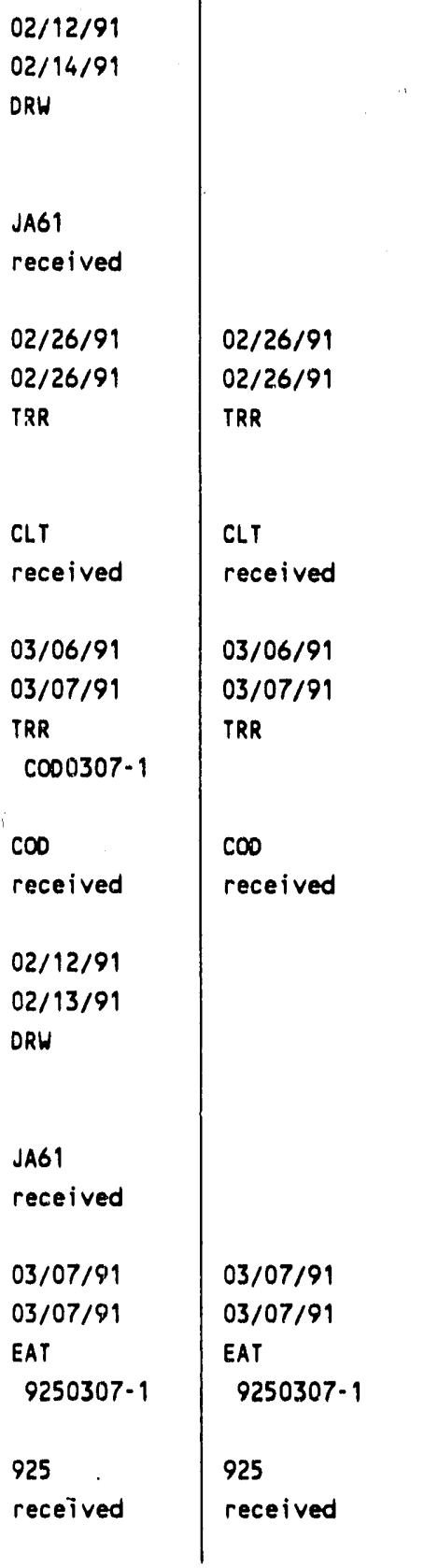


Babcock and Wilcox Co.

Radian Work Order: 91.02.047

\begin{tabular}{|c|c|c|c|c|c|}
\hline $\begin{array}{l}\text { Sample ID } \\
\text { Date Sampled } \\
\text { Date Received } \\
\text { Matrix }\end{array}$ & $\begin{array}{l}\text { Sample idint } \\
\text { LIMB EMPASH-09 } \\
02 / 05 / 91 \\
02 / 06 / 91 \\
01\end{array}$ & $\begin{array}{l}\text { tifications and } \\
\text { TCLP LEACH LI- } \\
\text { MB EMPASH-09 } \\
02 / 11 / 91 \\
02 / 06 / 91 \\
\text { Water } \\
02\end{array}$ & $\begin{array}{l}\text { Dates } \\
\text { TCLP BLANK } \\
\text { 02/06/91 } \\
\text { water } \\
\text { O3 }\end{array}$ & $\begin{array}{l}\text { DI LEACH LIMB } \\
\text { EMPASH-09 } \\
02 / 11 / 91 \\
02 / 06 / 91 \\
\text { water } \\
04\end{array}$ & $\begin{array}{l}\text { METHOD BLANK } \\
02 / 06 / 91 \\
\text { water } \\
05\end{array}$ \\
\hline 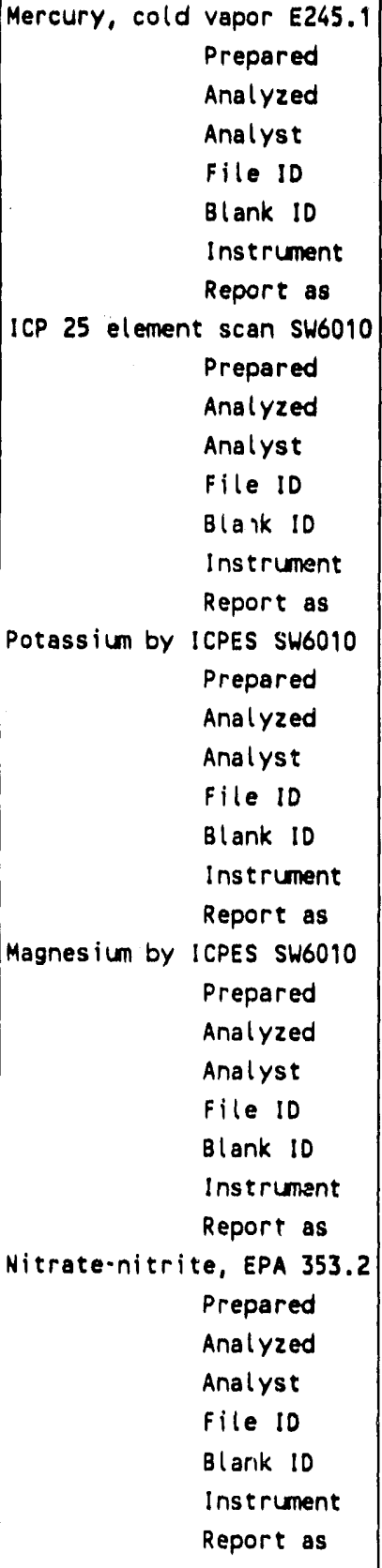 & & $\begin{array}{l}02 / 13 / 91 \\
02 / 13 / 91 \\
\text { MX2 } \\
403 \\
\text { received } \\
02 / 12 / 91 \\
02 / 13 / 91 \\
\text { DRH } \\
\text { JA61 } \\
\text { received }\end{array}$ & $\begin{array}{l}02 / 13 / 91 \\
02 / 13 / 91 \\
M \times 2 \\
403 \\
\text { received } \\
02 / 12 / 91 \\
02 / 13 / 91 \\
\text { DRH } \\
\text { JA61 } \\
\text { received }\end{array}$ & 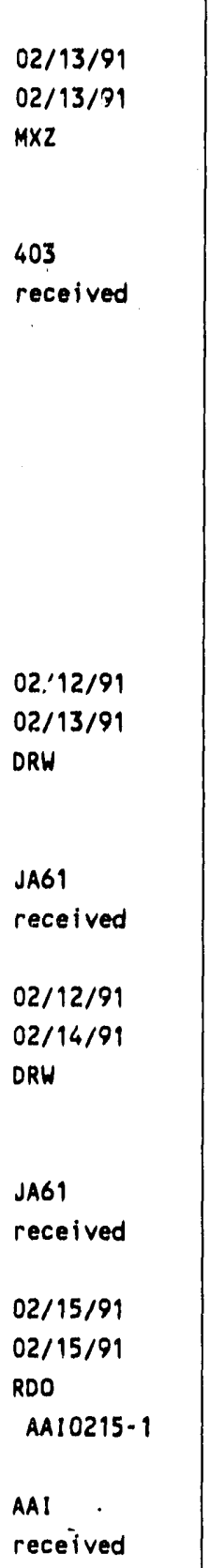 & 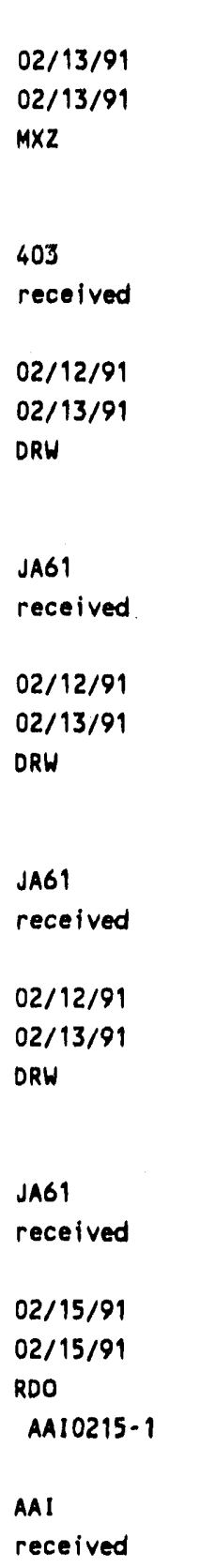 \\
\hline
\end{tabular}


Babcock and Wilcox Co:

Radian Work Order: 91-02-047

Sample Identifications and Dates

\begin{tabular}{|c|c|c|c|c|c|}
\hline Sample 10 & LIMB EMPASH-09 & $\begin{array}{l}\text { TCLP LEACH LI- } \\
\text { MB EMPASH-09 }\end{array}$ & TCLP BLANK & $\begin{array}{l}\text { OI LEACH LIMB } \\
\text { EMPASH-09 }\end{array}$ & METHOD BLANK \\
\hline Date Sampled & $02 / 05 / 91$ & $02 / 11 / 91$ & & $02 / 11 / 91$ & \\
\hline Date Recelved & $02 / 06 / 91$ & $02 / 06 / 91$ & $02 / 06 / 91$ & $02 / 06 / 91$ & $02 / 06 / 91$ \\
\hline Matrix & & & & water & water \\
\hline & 09 & 02 & 03 & 04 & 05 \\
\hline
\end{tabular}

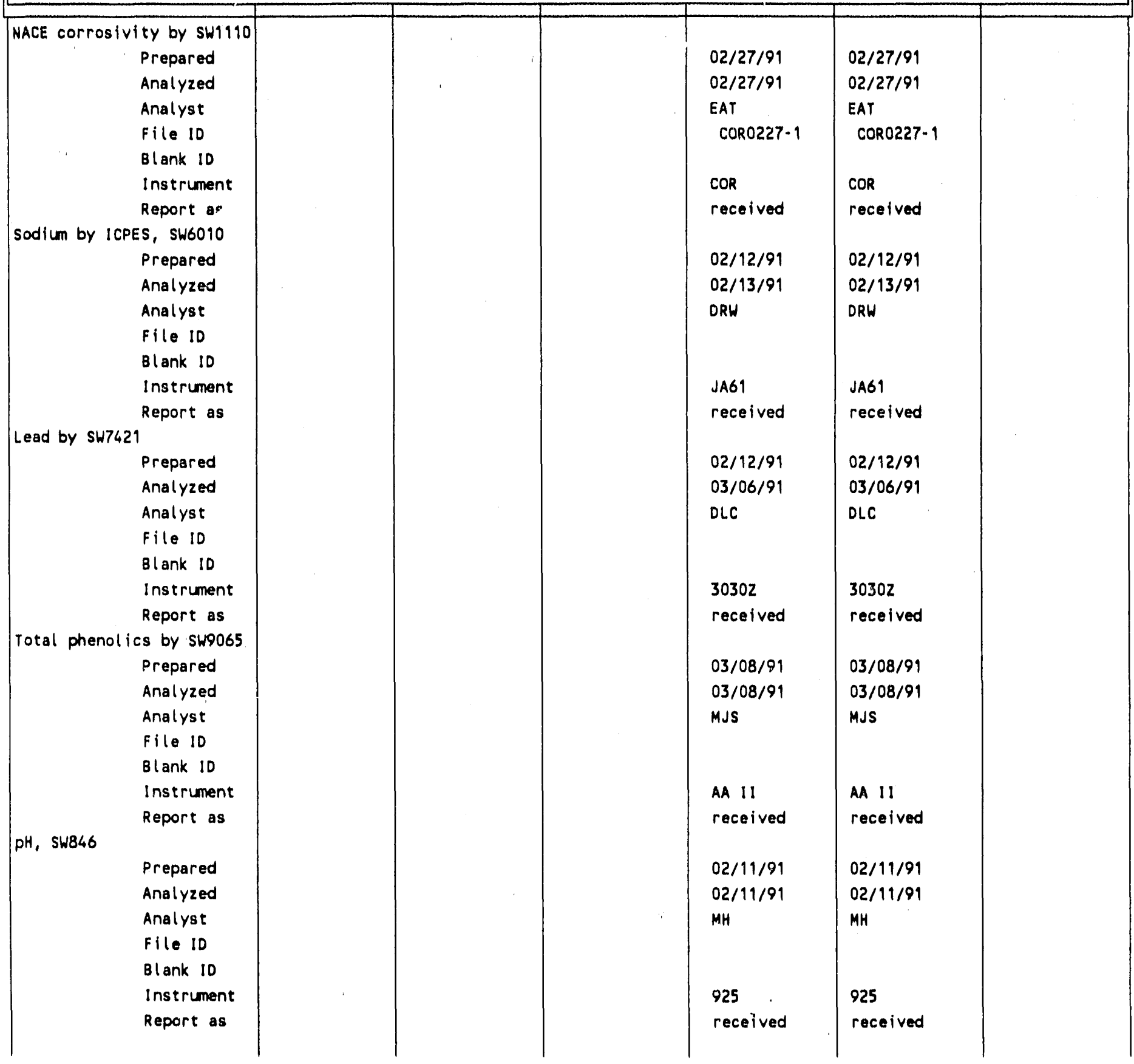


Babcock and Wilcox Co.

Radian Work Urder: 91-02-047

Sample Identifications and Dates

Sample 10

Date Sampled

Date Received

Matrix
LIMB EMPASH-09 TCLP LEACH LI- TCLP BLANK MB EMPASH-O9

\section{$02 / 05 / 91$ \\ $02 / 06 / 91$ \\ solid}

Selenium by SW7740

Prepared

Analyzed

Analyst

File 10

Blank 10

Instrument

Report as

sulfate, SW9038

Prepared

Analyzed

Analyst

File ID

$B$ lank 10

Instrument

Report as

TCLP leaching

Prepared

Analyzed

Analyst

File ID

Blank 10

instrument

Report as

Tot. dissolv. solid E160.1

Prepared

Analyzed

Analyst

File 10

Blank 10

Instrument

Report as

TOC by EPA 415.2

Prepared

Analyzed

Analyst

file 10

Blank 10

Instrument

Report as
01

\section{2/11/91}

$02 / 06 / 91$

water

02

$02 / 12 / 9$
$02 / 13 / 9$

RAA

30302

roceived

$02 / 11 / 91$

$02 / 12 / 91$

HD

received

02/06/91
water
03

03

$02 / 12 / 91$

$02 / 13 / 91$

RAA

received

(n)

TRR

$2100 \mathrm{~A}$

$02 / 11 / 91$

$02 / 12 / 91$

HD

received

04
DI LEACH LIMB METHOO BLANK EMPASH-09

$02 / 11 / 91$

02/06/91 02/06/91

water water

05

$02 / 12 / 91$

02/13/91

RAA

30302

received

03/01/91

03/01/91

TRR

$2100 \mathrm{~A}$

received

received

$02 / 13 / 91$

02/13/91

EAT

TDS0213-1

TDS

received

$02 / 14 / 91$

$02 / 14 / 91$

MH

DC -80 .

received
$02 / 14 / 91$

MH

DC -80

$02 / 13 / 91$

$02 / 13 / 91$

EAT

TDS0213-1

TDS

received

received 


\begin{tabular}{c} 
Appendix A \\
Comments, Notes and Definitions \\
\hline
\end{tabular}


Babcock and Wilcox co.

Radian Work Order: 91.02 .047

- ALL METHOOS EXCEPT CLP

The results which are less than five times the method specified detection limit.

EXPLANATION

Uncertainty of the analysis will increase as the method detection

limit is approached. These results should be considered approximate.

ND ALL METHOOS EXCEPT CLP

This $f$ lag is used to denote analytes which are not detected at or above the specified detection limit.

EXPLANATION

The value to the right of the < symbol is the method specified detection limit for the analyte. 
Babcock and Wilcox Co.

Radian Work Order: $91-02-047$

TERMS USED IN THIS REPORT:

Analyte - A chemical for which a sample is to be analyzes. The analysis will meet EPA method and QC specifications.

Compound - See Analyte.

Detection Limit - The method specified detaction limit, which is the lower limit of quantitation specified by EPA for a method. Radian staff regularly assess their laboratories' method detection limits to verify that they meet or are lower than those specified by EPA. Detection limits which are higher than method limits are based on experimental values at the $99 \%$ confidence level. The detection limits for EPA CLP (Contract Laboratory Program) methods are CRQLs (contract required quantitation limits) for organics and CRDLs (contract required detection (imits) for inorganics. Note, the detection limit may vary from that specified by EPA based on sample size, dilution or cleanup. (Refer to Factor, below)

EPA Method - The EPA specified method used to perform an analysis. EPA has specified standard methods for analysis of environmental samples. Radian will perform its analyses and accompanying OC tests in conformance with EPA methods unless otherwise specified.

Factor - Default method detection limits are based on analys is of clean water samples. A tactor is required to calculate sample specific detection limits based on alternate matrices (soil or water), reporting units, use of cleanup procedures, or dilution of extracts/ digestates. For example, extraction or digestion of 10 grams of soil in contrast to 1 liter of water will result in a factor of 100.

Matrix - The sample material. Generally, it will be soil, water, air, oil, or solid waste.

Radian Work Order - The unique Radian identification code assigned to the samples reported in the analytical summary.

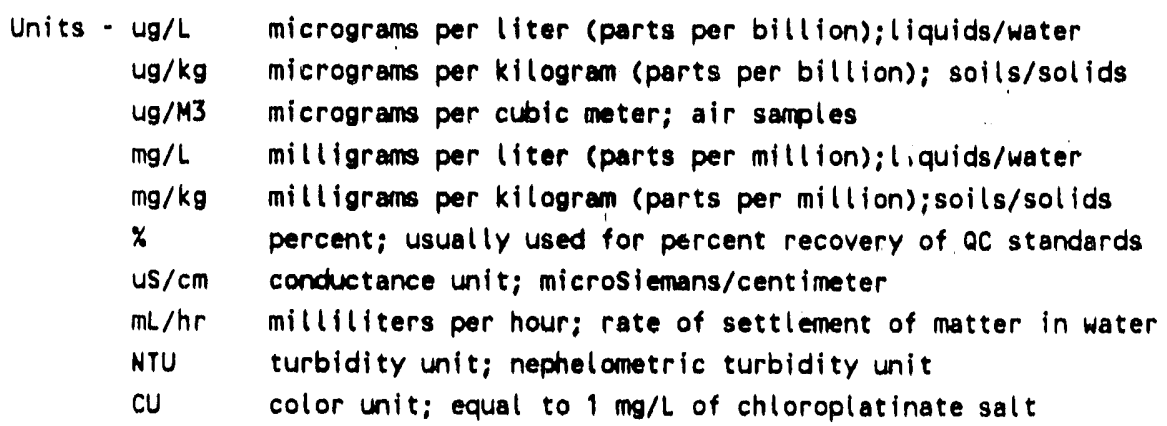


Analytical Report

$04 / 10 / 91$

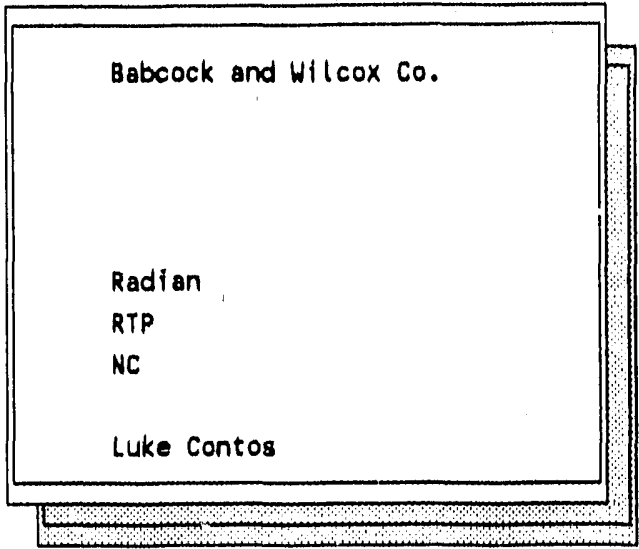

Customer Work Identification LIMB PROJECT

Purchase Order Number 209-026-05-00

\section{Contents:}

1 Analytical Data Summary

2 Sample History

3 Comments Summary

4 Notes and Definitions

Radian Analytical Services

8501 Mo-Pac Boulevard

P. O. BoX 201088

Aust in, iX 78720-1088

$512 / 454-4797$

Client Services Coordinator: KAYOUNG

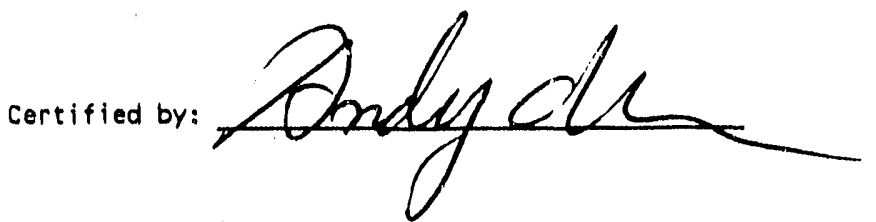


Babcock and Wilcox Co.

Radian Work Order: 91.03-019

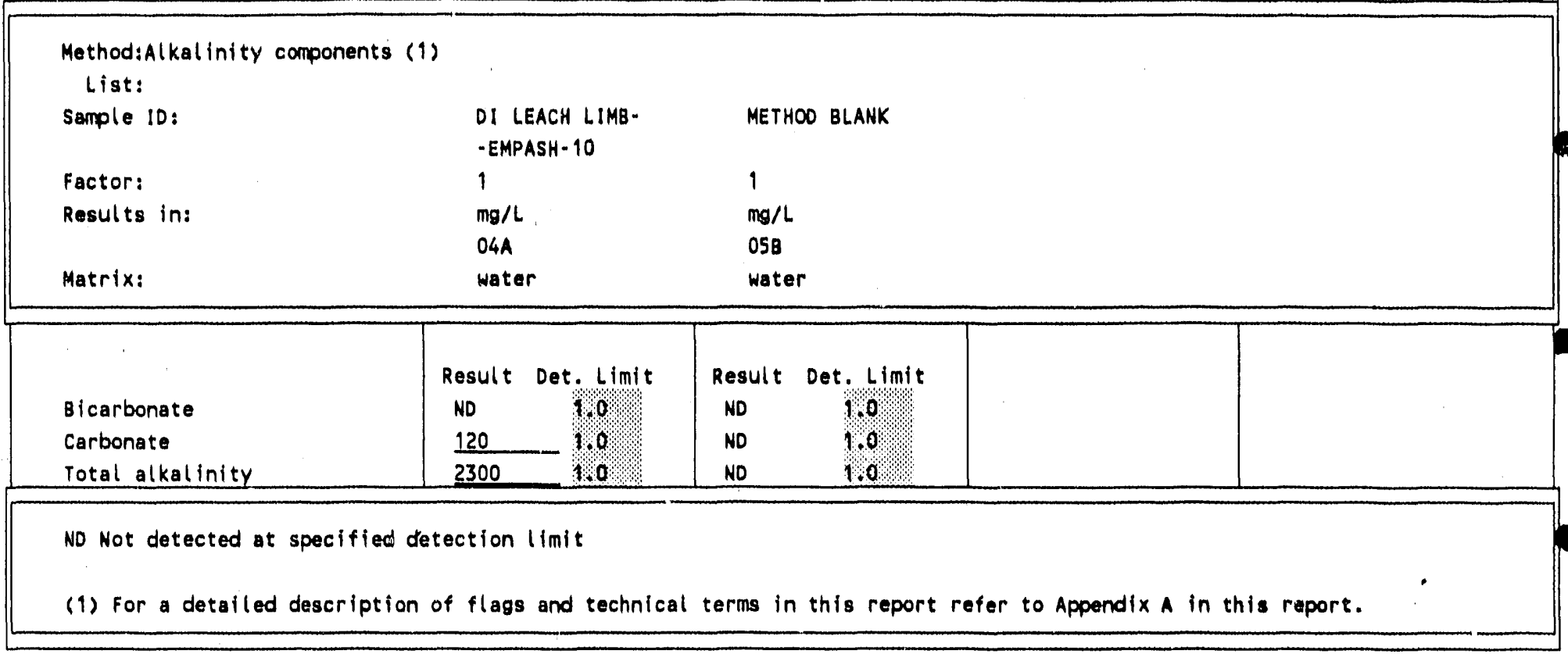


Babcock and Wilcox Co.

Radian Work Orders 91-03.011

Method: ISP 25 element scan $\$ W 6010$ (1)

ListiICP, TCLP MS

Semple ID:

TCLP LEACH LI-

TCLP BLANK MB-EMPASH- 10

Factor:

Results in:

Matrix:

$\mathrm{mg} / \mathrm{L}$

O2A

water

1

$\mathrm{mg} / \mathrm{L}$

03B

water
METHOD BLANK

1

$\mathrm{mg} / \mathrm{h}$

05A

water
TCLP LEACH MS

0

Xreovry

O6A

Nater

\begin{tabular}{|c|c|c|c|c|c|c|c|c|}
\hline & Result $D$ & Det. Limit & Result & Det. LImit & Resul & Det. Limit & Result & Det. Limit \\
\hline Arsenic & ND & 18 & ND & 0.30 & ND & 0,30 & 112 & \\
\hline Barium & 1.1 & 0.040 & 0.96 & 0,010 & ND & 9010 & 640 & \\
\hline Cacmium & ND & 0020 & ND & 0.0050 & ND & 00096 & 98 & \\
\hline Chromium & 0.0180 & -800 & ND & 0.010 & ND & 0.010 & 85 & \\
\hline Lead & ND & 0.20 & NO & 0.050 & ND & 0,050 & 480 & \\
\hline silver & ND & 0.040 & ND & 0.010 & ND & 0,010 & 94 & \\
\hline
\end{tabular}

ND Not detected at specified detection limit

a Est. result less that 5 times detection limit a Outside control limits

(1) For a detailed description of $f$ lags and technical terms in this report refer to Appendix $A$ in this repcrt. 
Babcook and Wilcox Co.

Radian Work Orders 91.03.011

MethodilCP 25 element scan SW6010 (1)

ListIICP, TCLP MS

Sample 1D:

TCLP LEACH MSO

Factor: 0

Results in: Xrocury

07A

Matrix:

water

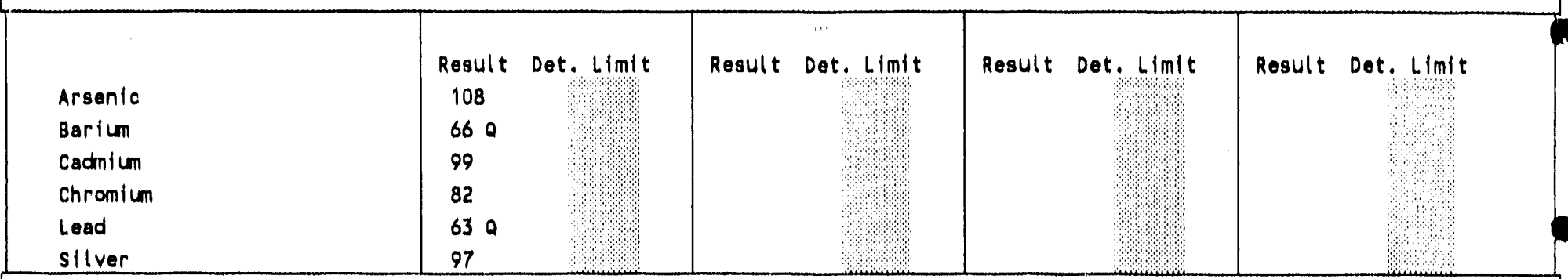

Q outside control limits

(1) For a detailed description of flags and technical terms in this report refor to Appendix $A$ in this report. 
Babcock and Wiloox Co.

Radian Work Ordert 91.03-011

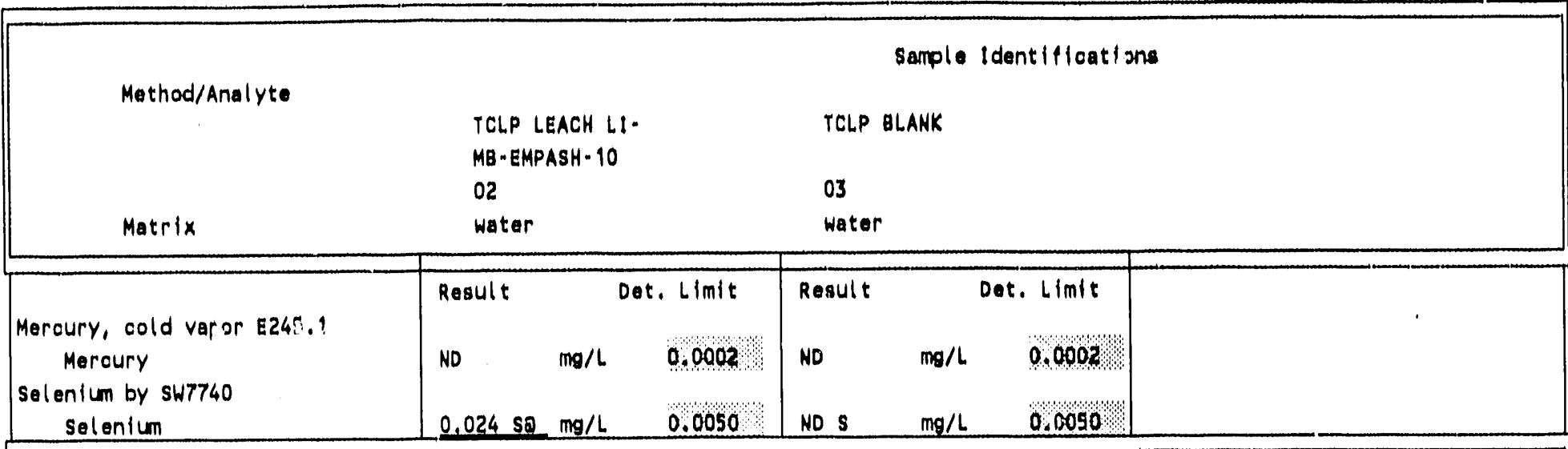

No Not detected at spoclfied detaction $1 \mathrm{im} / \mathrm{t}$

s Determined by Method of Standard Addition

a Est. result loss that 5 times detaction Iimit

(1) For a detalled description of flags and technical terms in this report refer to the glossary. 
Baboock and Wiloox co.

Radian Work Order: 91.03 .011

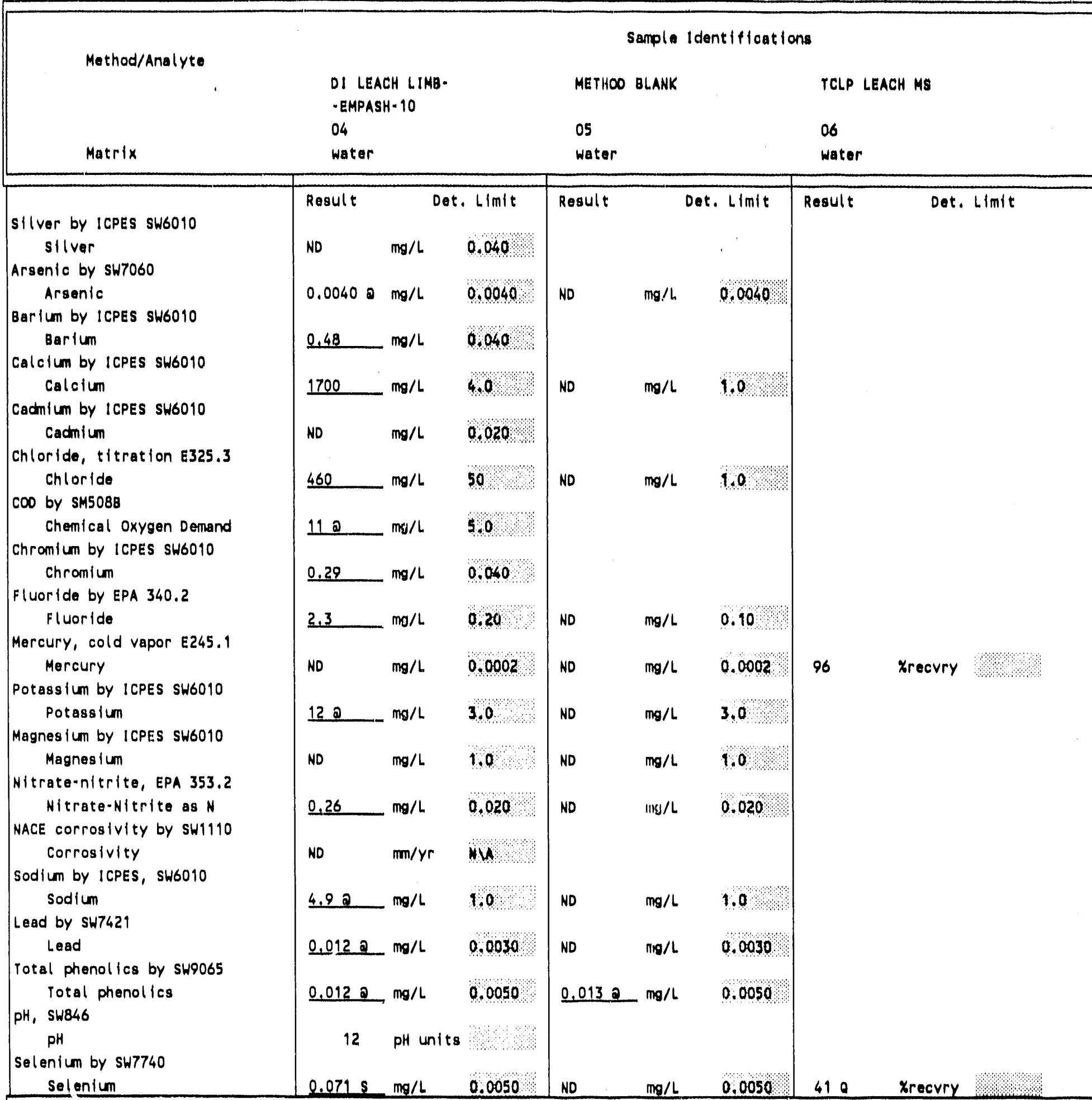

NO Not detected at speclfied detection limit

$S$ Determined by Method of Standard Addition
Q Est. result. less that 5 imes detection Iimit

Q outside control limits

(1) For a detalled description of flags and technical terms in this report fefer to the glossary. 
Baboock and Wilcox Co.

Radian Work Orders 91-03-011

\begin{tabular}{|c|c|c|c|c|c|c|c|}
\hline Method/Analyte & \multicolumn{2}{|c|}{$\begin{array}{l}\text { DI LEACH LIMB- } \\
\text {-EMPASH- } 10 \\
04 \\
\text { water }\end{array}$} & \multicolumn{2}{|c|}{$\begin{array}{l}\text { METHOO BLANK } \\
05 \\
\text { water }\end{array}$} & ntifloat & ns & \\
\hline $\begin{array}{l}\text { Sulfate, SW9038 } \\
\text { Sulfate } \\
\text { Tor. dissolv. solfid E } 160.1 \\
\text { Total dissolved sollds } \\
\text { TOC by EPA } 415.2 \\
\text { Total organic carbon }\end{array}$ & 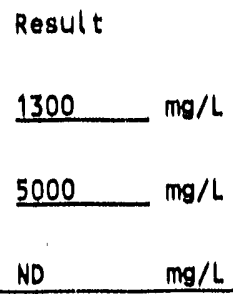 & 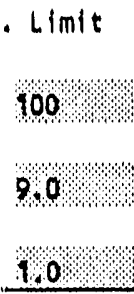 & $\begin{array}{l}\text { Result } \\
\text { ND } \\
\text { ND } \\
\text { ND }\end{array}$ & $\begin{array}{l}m g / L \\
m g / L \\
m g / L\end{array}$ & $\begin{array}{l}\text { Limit } \\
100 \\
90 \\
1,0\end{array}$ & Result & Det. Limit \\
\hline $\begin{array}{l}\text { No Not detected at spe } \\
\text { (1) for a dctalled des }\end{array}$ & $\begin{array}{l}\text { detection limit } \\
\text { of } f \text { lags and }\end{array}$ & ical te & in thi & mon & $r$ & & \\
\hline
\end{tabular}


Babcock and Wilcox Co.

Radian Work Order: 99-03.011

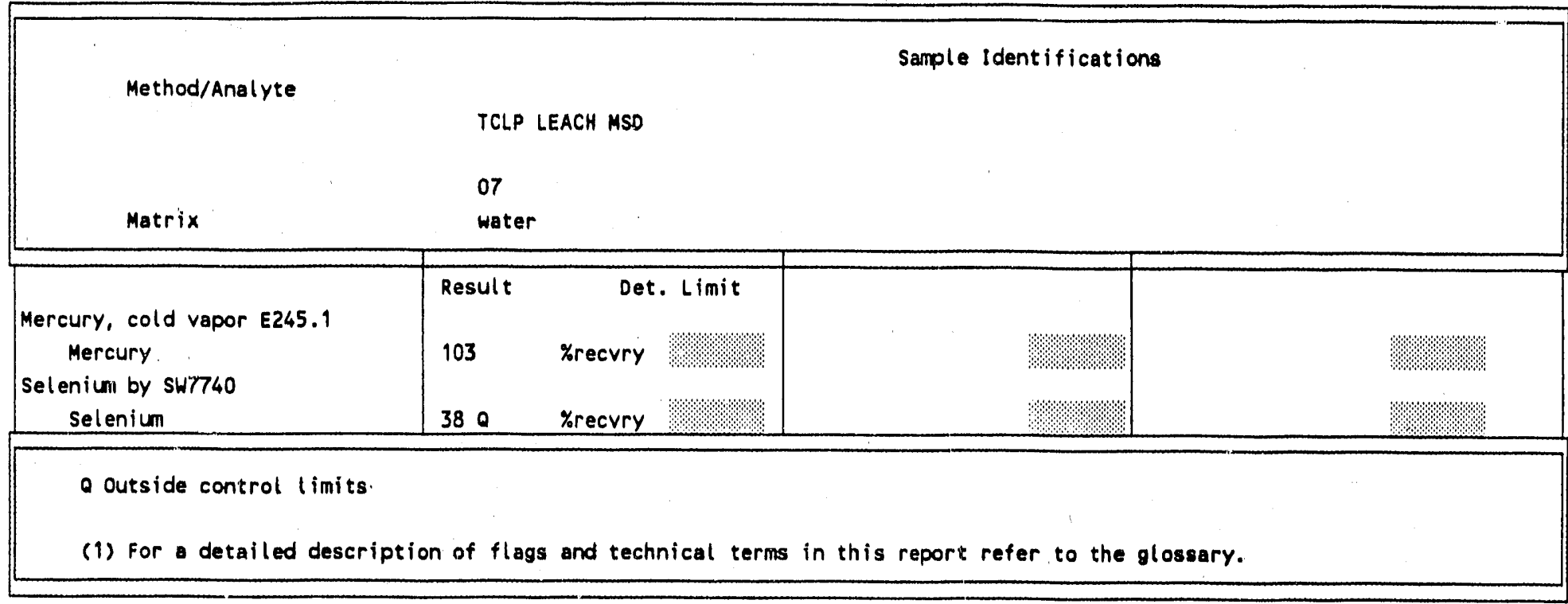


Babcock and Wilcox Co.

Radian Work Order: 91-03-011

Sample Identifications and Dates

Sample 10

Date Sampled

Date Received

Matrix
LIMB-EMPASH-10 TCLP LEACH LI- TCLP BLANK MB-EMPASH- 10

$02 / 28 / 91 \quad 03 / 04 / 91$

$03 / 01 / 91$

01

$03 / 01 / 91$

$03 / 01 / 91$

03

02

OI LEACH LIMB- METHOO BLANK

TCLP LEACH MS -EMPASH- 10

03/06/91 03/04/91

03/01/91 03/01/91 03/01/91

water water

O4 $05 \quad 06$

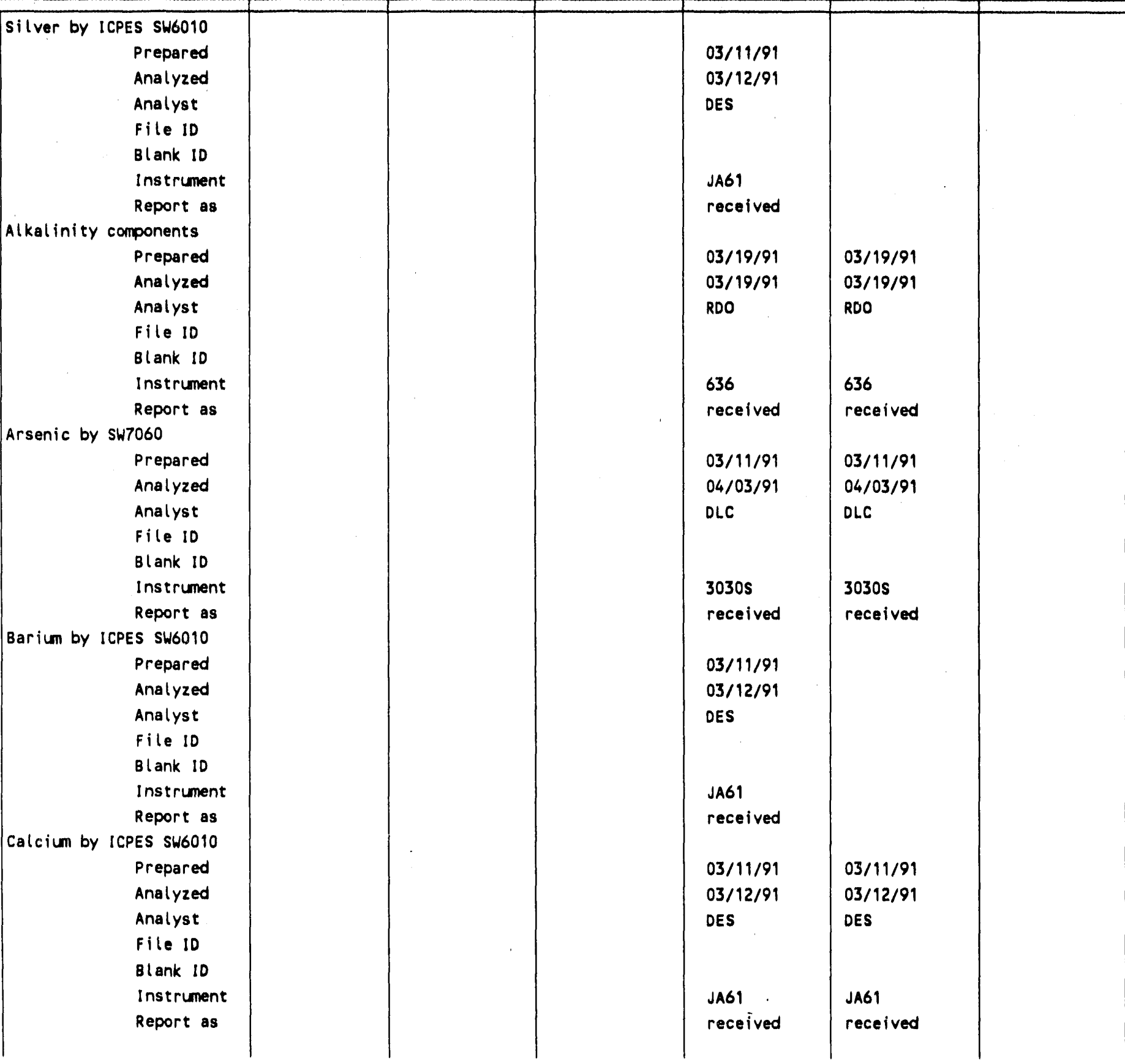


Babcock and Wilcox Co.

Radian Work Order: 91-03-011

Sample Identifications and Dates

Sample ID

Date Sampled

Date Received

Matrix
LIMB-EMPASH-10 TCLP LEACH LI- TCLP BLANK MB-EMPASH-10

$02 / 28 / 91 \quad 03 / 04 / 91$

$03 / 01 / 91$

03/01/91

02

03
03/01/91
DI LEACH LIMB - METHOO BLANK TCLP LEACH MS -EMPASH- 10

03/06/91

$03 / 01 / 91$

water

04

\section{3/04/91}

03/01/91 03/01/91

water

05

06

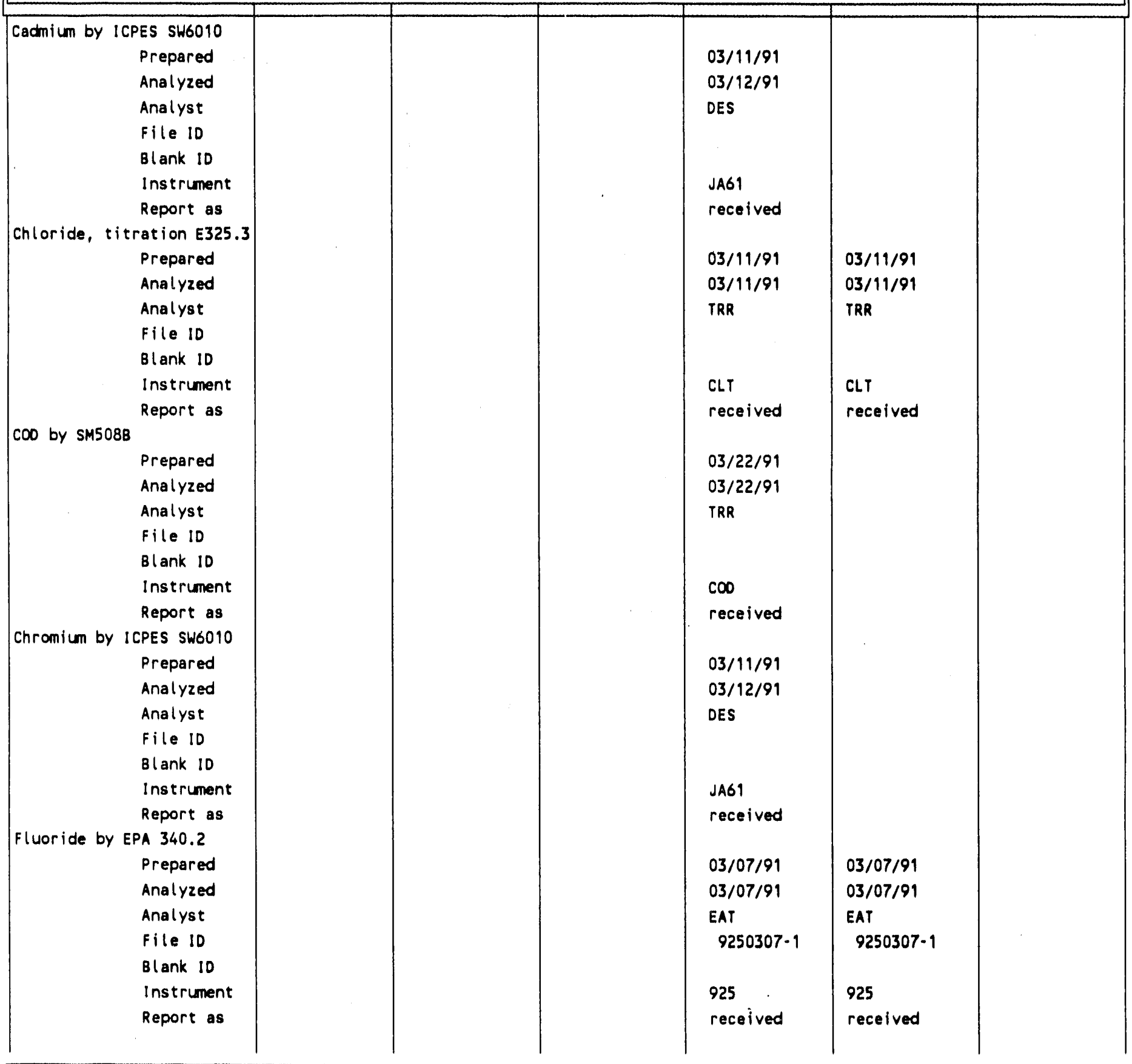


Babcock and Wilcox Co.

Radian Work Order: 91-03-011

Sample Identifications and Dates

Sample 10

Date Sampled

Date Received

Matrix
LIMB-EMPASH-10 TCLP LEACH LI- TCLP BLANK

M8-EMPASH- 10

02/28/91 03/04/91

$03 / 01 / 91$

01

$03 / 01 / 91$

water

02
3/07/91

03/07/91

MXZ

Analyst

File ID

Blank 10

Instrument

Report as

ICP 25 element scan SW6010

Prepared

Analyzed

Analyst

Fiie 10

Blank ID

Instrument

Report as

Potassium by ICPES SW6010

prepared

Analyzed

Analyst

File 10

Blank ID

Instrument

Report as

Magnesium by ICPES SW6010

Prepared

Analyzed

Analyst

File ID

Blank 10

Instrument

Report as

Nitrate-nitrite, EPA 353.2

Prepared

Analyzed

Analyst

File id

Blank 10

Instrument

Report as

\begin{tabular}{l|l}
403 & $\begin{array}{l}403 \\
\text { received }\end{array}$ \\
$03 / 11 / 91$ & $03 / 11 / 9$ \\
$03 / 12 / 91$ & $03 / 12 / 9$ \\
DES & DES
\end{tabular}

JA61

received
OI LEACH LIMB * METHOO BLANK -EMPASH- 10

03/06/91 03/04/91

03/01/91 03/01/91 03/01/91

water water water

$04 \quad 0506$

$\begin{array}{llll}03 & 04 & 05 & 06\end{array}$

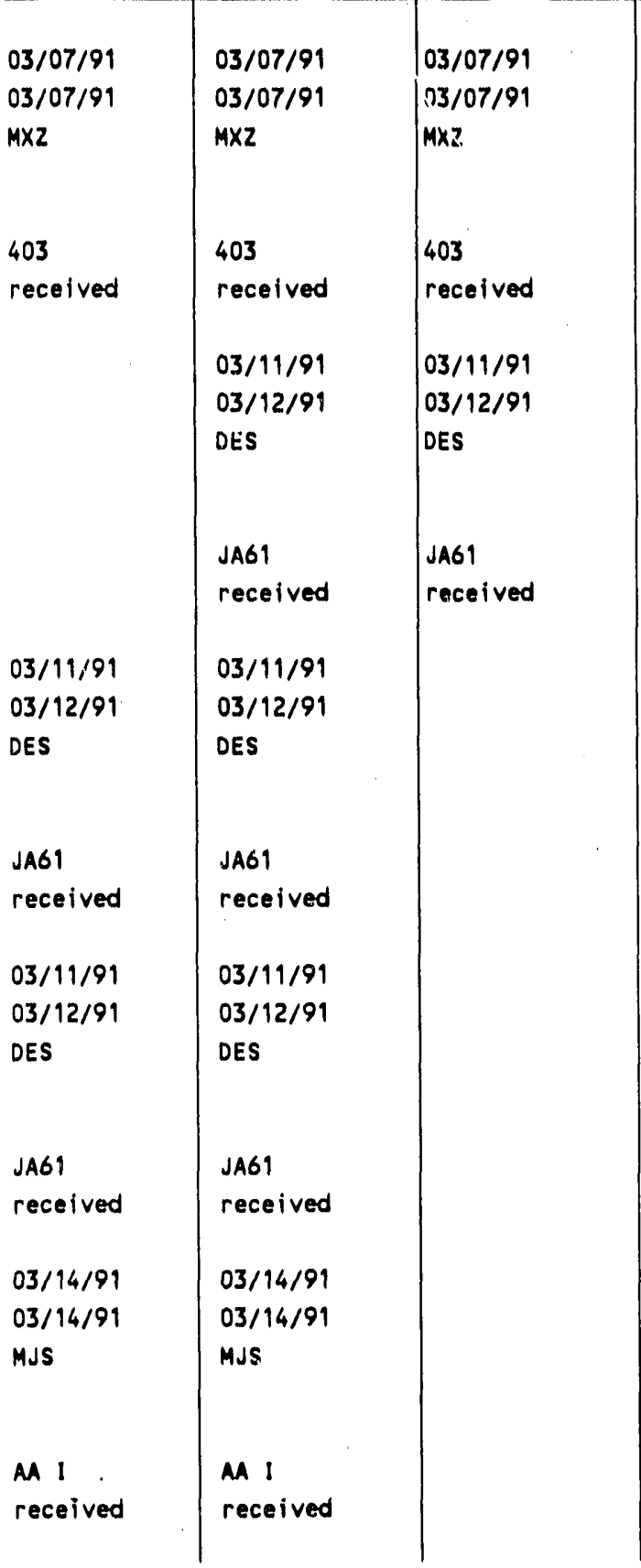


Babcock and Willcox co.

Radian Work Order: 91.03-011

Sample Identifications and Dates

Semple ID

Date Received

Matrix
LIMB-EMPASH-10 TCLP LEACH LI- TCLP BLANK

MB-EMPASH - 10

$02 / 28 / 91 \quad 03 / 04 / 91$

$03 / 01 / 91$

$03 / 01 / 91$

02

03
$03 / 01 / 91$
DI LEACH LIMB- METHOO BLANK -EMPASH-10

03/01/91

water
04
TCLP LEACH MS

$03 / 04 / 91$

$03 / 01 / 91$

NACE corrosivity by SW1110

Prepared

Analyzed

Analyst

File 10

Blank 10

Instrument

Report as

Sodium by ICPES, SW6010

Prepared

Analyzed

Analyst

File id

Blank 10

Instrument

Report as

Lead by SW7421

Prepared

Analyzed

Analyst

File ID

Blank 10

Instrument

Report as

Total phenolics by SW9065

Prepared

Analyzed

Analyst

File 10

$B$ lank 10

Instrument

Report as

pH， SW846

Prepared

Analyzed

Analyst

File ID

Blank 10

Instrument

Report as

$04 / 05 / 91$

$04 / 07 / 91$

EAT

NA

received

$03 / 11 / 91$

$03 / 12 / 91$

DES

$03 / 11 / 91$

$03 / 12 / 91$

DES

JA61

received

$03 / 11 / 91$

04/03/91

RAA

3030E

received

$03 / 27 / 91$

$03 / 27 / 91$

MuS

AA II

received

$03 / 07 / 91$

03/07/91

EAT

9250307-1

925

recoived
06 
Babcock and Wilcox co.

Radian Work Order: 91.03-011

Sample identifications and Dates

Sample ID

Date Received

Mairix
LIMB-EMPASH-10 TCLP SEACH LI- TCLP BLANK MB-EMPASH-10

\section{$02 / 28 / 91$ \\ 03/04/91}

03/01/91

solid

01

$03 / 01 / 99$

water

02

water

Selenium by SW7740

Prepared

Analyzed

Analyst

File 10

Blank 1D

Instrument

Report as

Sulfate, SW9038

Prepared

Analyzed

Analyst

File 10

Blank 10

instrument

Report as

TCLP leaching

Prepared

Analyzed

Analyst

File ID

8 lank 10

Instrument

Report as

Tot. dissolv. solid E160.1

Prepared

Analyzed

Analyst

File id

$B$ lank 10

Instrument

Report as

TOC bY EPA 415.2

Prepared

Analyzed

Analyst

File 10

Blank 10

Instrument

Report as

$03 / 11 / 91$

03/15/91

DLC

received

03/05/91

HD

$03 / 05 / 91$

HD

received

$03 / 11 / 91$

OLC

30302

received

received
03

OI LEACH LIMB - METHOO BLANK -EMPASH-10

03/01/91

water

O4

$03 / 13 / 91$

$03 / 13 / 91$

EAT

30302

received

$03 / 14 / 91$

$03 / 14 / 91$

TRR

$2100 \mathrm{~A}$

received

$2100 \mathrm{~A}$

received

TDS

received

$03 / 28 / 91$

$03 / 28 / 91$

MH

DC- 80 .

received

$03 / 14 / 91$

03/14/91

TRR

$03 / 13 / 91$

03/13/91

EAT

TDS

received

$03 / 28 / 91$

$03 / 28 / 91$

MH

DC- 80

received
TCLP LEACH MS

$03 / 04 / 91$

$03 / 01 / 91$

water

06

$05 \quad 06$

(2)

\begin{tabular}{l|l}
$03 / 11 / 91$ & $03 / 11 / 91$ \\
$03 / 15 / 91$ & $03 / 15 / 91$
\end{tabular}

DLC

DLC

30302

30302

received

received 
Babcock and Wilcox Co.

Radian Work Order: 91.03-011

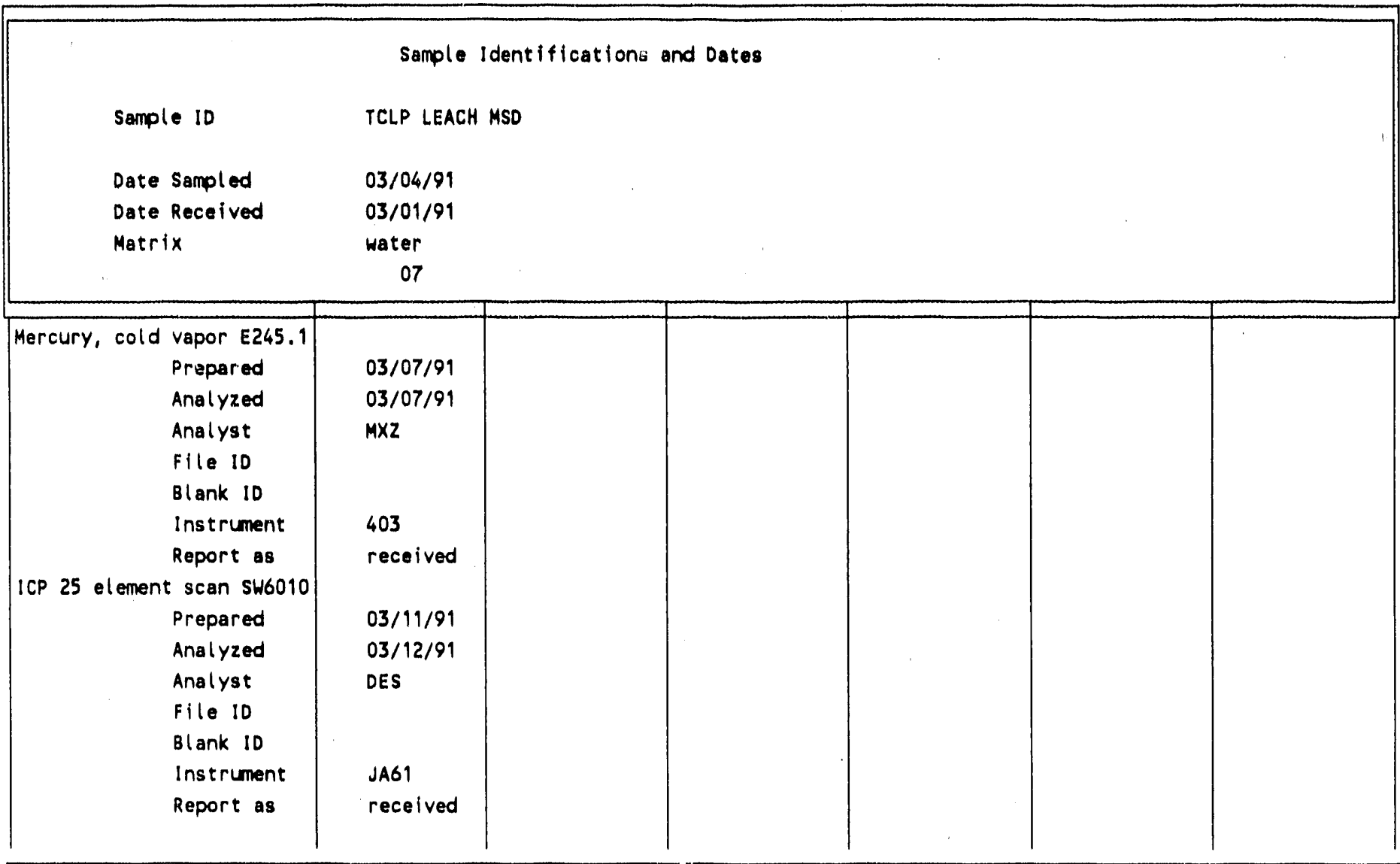


Babcock and Wilcox co.

Radian Work Order: 91-03-011

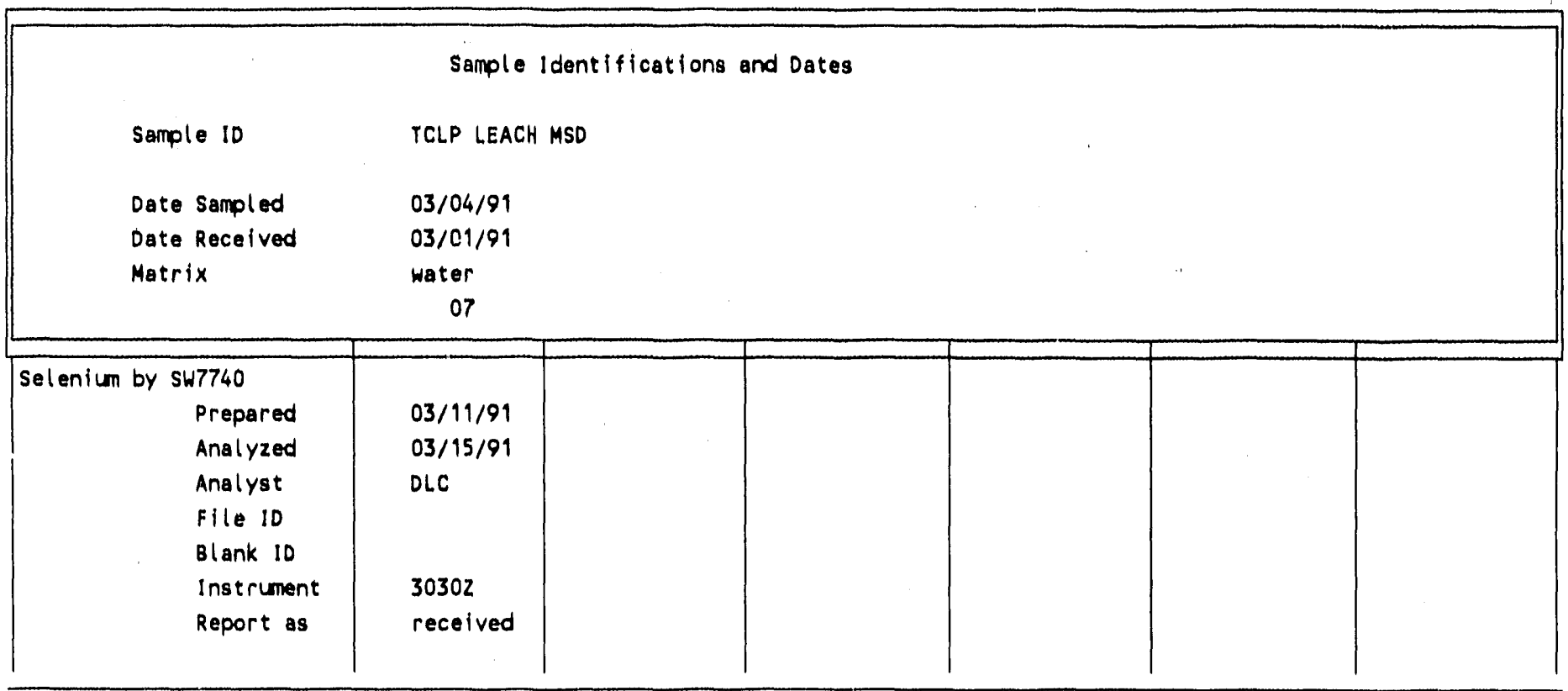

- 


\section{RADIAN}

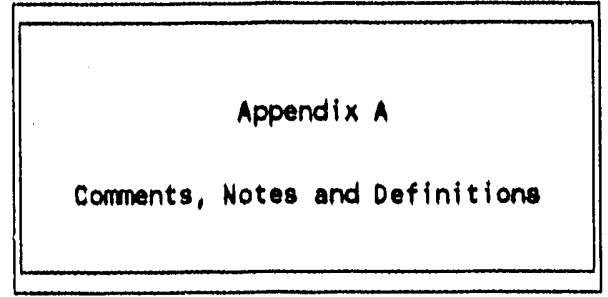

-

$\bullet$

○

○

e

$F-31$

C 
Babcock and Wilcox Co.

Radian Work Ordier: 91.03 .011

Qeneral Comments

Samples 9103019-02A,.06A Ms, and -07A MSD had to be diluted by factor of four to eliminate interferences from calcium. The low recovery for lead may be due to the dilution of the spike to within five times the IDL. 
Baboock and Willoox Co.

Radian Work Orders 91.03 .011

@ ALL METHOOS EXCEPT CLP

The results which are loss than flve times the method speclfled detection limit.

EXPLANATION

Uncertainty of the analys is will inorease as the mathod detection

IImit is approached. These results should be consldered approximate.

ND ALL METHOOS EXCEPT CLP

This flag is issed to denote analytes which are not detected at or above the speclifled detection IImit.

EXPLANATION

The value to the right of the symbol is the method spectfled detection limit for the analyte.

Q ALL METHOOS EXCEPT CLP

This quality control standard is outside method or laboratory speo.

lfied control limits.

EXPLANATION

This flag is appliod to matrix spike, analytical aC spike, and surrogate recoverles; and to RPD(relative percent diffurence) values for duplloate analyses and matrix spike/matrix spike duplicate result.

INOROANIC METHOOS INCLUDINQ CLP

This flag indicates that a specific result from analysis has been obtained using the Method of Standard Addition. 
Babcook and Willoox Co.

Radian Work Ordart 91.03.011

TERMS USED IN THIS REPORT:

Analyte - A chemloal for whloh a sample is to be analyzed. The analyals wlll meet EPA method and OC specifleatlons.

Compound - See Analyte.

Detaction LImlt . The method specifled deteotion $1 / \mathrm{mit}$, which is the lower $1 / \mathrm{m} / \mathrm{t}$ of quantitation specifled by EPA for a method. Radian ataff regularly assess their laboratorles' method detection $11 \mathrm{mits}$ to verify that they moet or are lower than those specifled by EPA. Detection $1 / \mathrm{m} / \mathrm{ts}$ whlah are higher than method $1 / \mathrm{mi}$ ts are based on axperimental values at the $99 \%$ confldence lovel. The detection limits for EPA CLP (Contract Laboratory Program) mathods are CRQL s (contract required quantitation limits) for organics and CROLs (contract required dateotion limits) for inorganica. Note, the detection limit may vary from that specifled by EPA based on sample size, dilution or oleanup. (Refor to factor, below)

EPA Method - The EPA specifled method used to perform an analysis, EPA has spacifled atandard methods for analysis of environmental samples. Radian will perform its analyses and accompanying QC tests in conformance with EPA methods unless otherwise specifled.

Factor - Default method detection limits are based on analysis of oloan water samples. A factor is required to calculate sample specifle detection $1 / \mathrm{mits}$ based on al ternate matrices (soll or water), reporting unlts, use of cleanup procedures, or dilution of extracts) digestates. For example, extraction or digestion of 10 grams of soll in contrast to 1 llter of water wlll result in a factor of 100 .

Matrlx - The sample materlal, oenerally, it will be soil, water, air, oll, or solid waste.

Radian Work Order - The unique Radian Identiflcation code assigned to the samples reported in the analytical surmary.

Units - ug/L micrograms per lifer (parts per billion); llquids/water ug/kg miorograms per kilogram (parts per billlon); solls/sollds ug/M3 micrograms per cubic meter; alr samples

$\mathrm{mg} / \mathrm{h} \quad$ milligrams per llter (parts per million);llquids/water $\mathrm{mg} / \mathrm{kg} \quad$ milligrans per kilogram (parts per million); solls/solids * percent; usually used for percent recovery of AC standards us/cm conductance unit; microsiemans/centimeter $\mathrm{mL} / \mathrm{hr}$ millilliters per hour; rate of settlement of matter in water NTU turbidity unit; nephelometric turbidity unit CU color unit; qual to $1 \mathrm{mg} / \mathrm{L}$ of chloroplatinate salt 


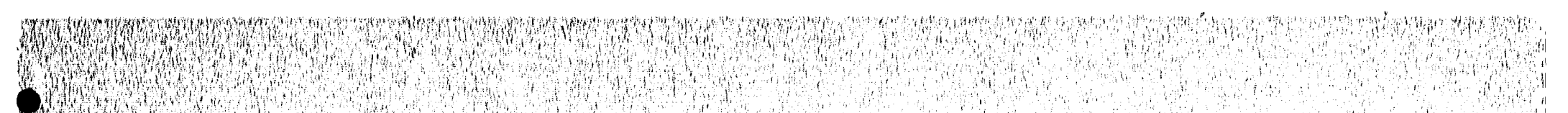

\section{APPENDIX G}

PERMIEABILITY DATA SUMMARY 
Analytioal Report

03/15/91

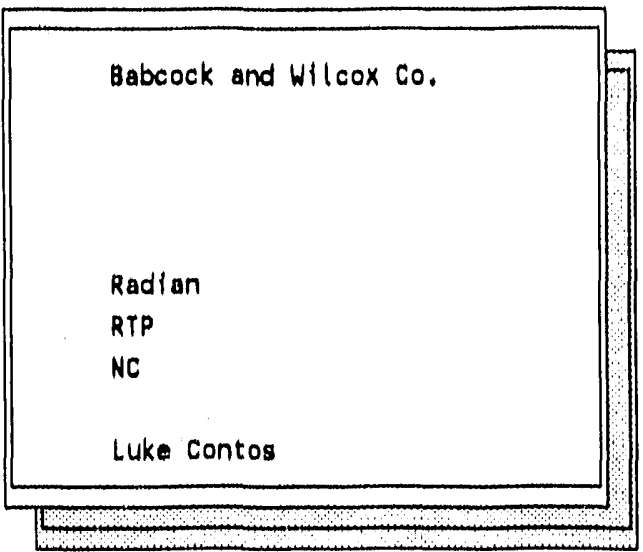

Customer Work Identification LIMB PROJECT Purchase Order Number 209-026-05-00

\begin{tabular}{|ll|}
\hline & Contents: \\
1 & Analytical Data Summary \\
2 & Sample History \\
3 & Comments Summary \\
4 & Notes and Definitions
\end{tabular}

Radian Analytical Services 8501 Mo-Pac Boulevard P. O. BOX 201088 Aust in, ix 78720-1088

$$
512 / 454-4797
$$

Client Services Coordinator: KAYOUNG

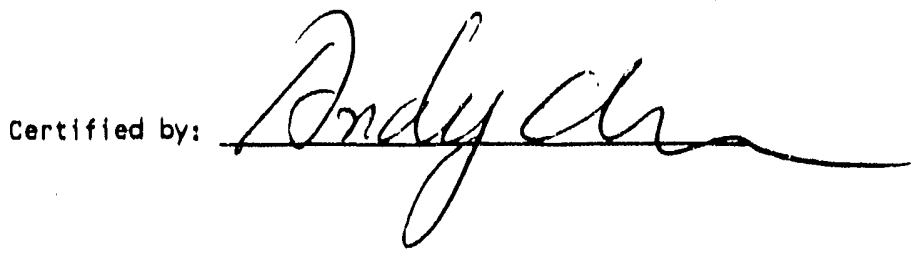

$$
\text { G-1 }
$$


Babcock and Wilcox Co.

Radian Work Order: 91.02 .048

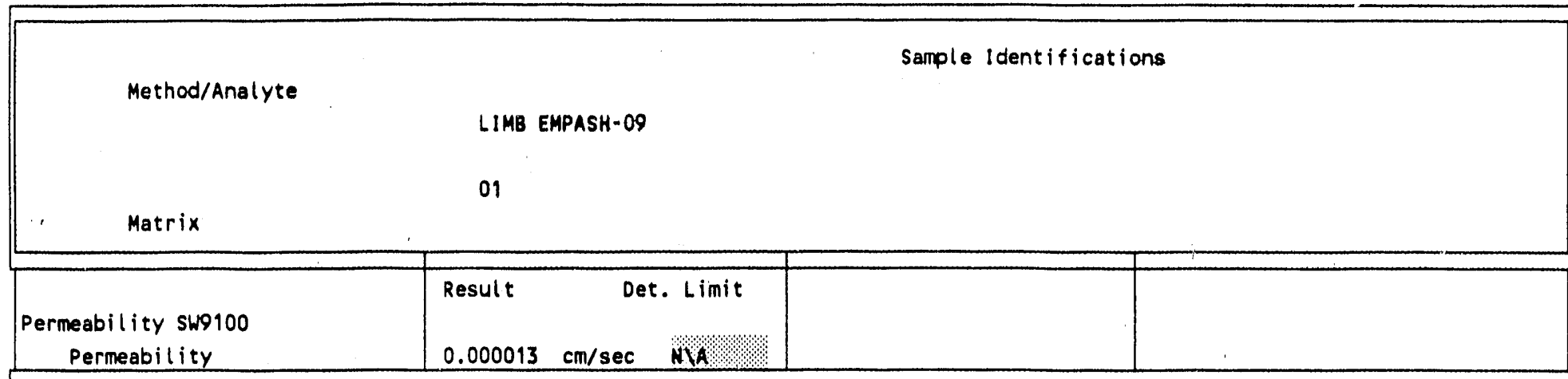

(1) For a detailed description of flags and technical terms in this report refer to the glossary. 
Babcock and Wilcox Co.

Radian Work Order: 91.02 .048

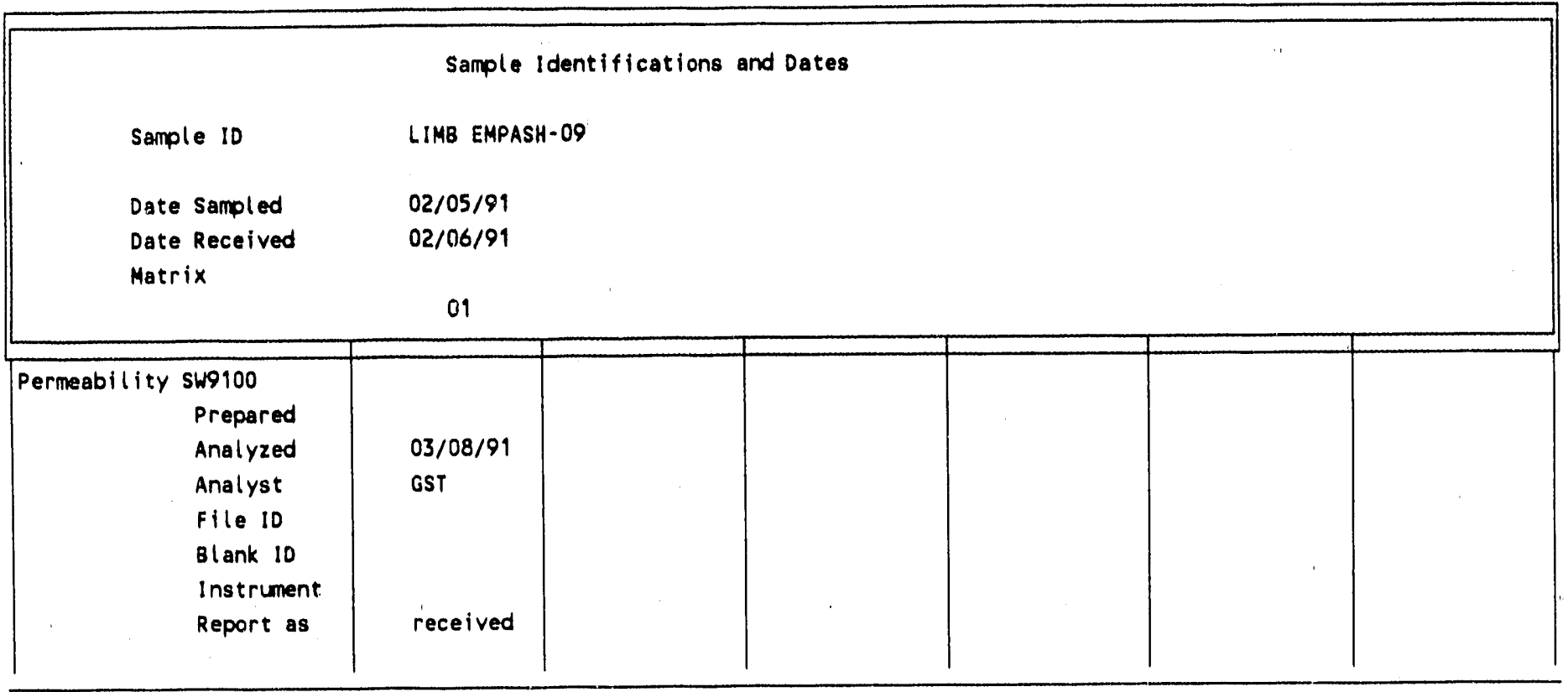




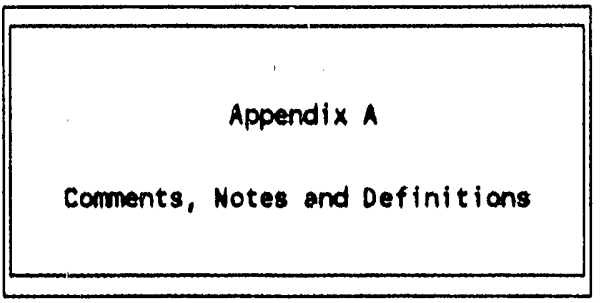

-

G-4

- 
Babcock and Wilcox Co.

Radian Work Order: $99-02.048$

TERMS USED IN THIS REPORT:

Analyte - A chemical for which a sample is to be analyzed. The analysis will meet EPA method and QC specifications.

Compound - See Analyte.

Detection Limit - The method specified detection limit, which is the lower limit of quantitation specified by EPA for a method. Radian staff regularly assess their laboratories' method detection limits to verify that they meet or are lower than those specified by EPA. Detection limits which are higher than method limits are based on experimental values at the $99 \%$ confidence level. The detection limits for EPA CLP (Contract Laboratory Program) methods are CRQLs (contract required quantitation (imits) for organics and CROLs (contract required detection limits) for inorganics. Note, the detection limit may vary from that specified by EPA based on sample size, dilution or cleanup. (Refer to Factor, below)

EPA Method - The EPA specified method used to perform an analysis. EPA has specified standard methods for analysis of environmental samples. Radian will perform its analyses and accompanying aC tests in conformance with EPA methods unless otherwise specified.

Factor - Default method detection limits are based on analysis of clean water samples. A factor is required to calculate sample specific detection limits based on alternate matrices (soil or water), reporting units, use of cleanup procedures, or dilution of extracts/ digestates. For example, extraction or digestion of 10 grams of soil in contrast to 1 liter of water will result in a factor of 100 .

Matrix - The sample material. Generally, it will be soil, water, air, oil, or solid waste.

Radian Work Order - The unique Radian identification code assigned to the samples reported in the analytical summary.

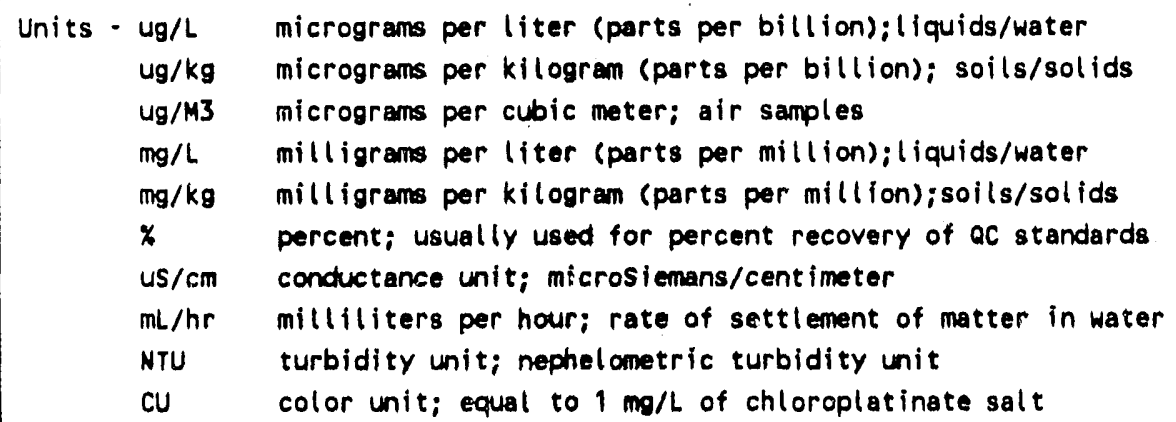


Radian Work Order 91-03-009

Analytical Report

04/04/91

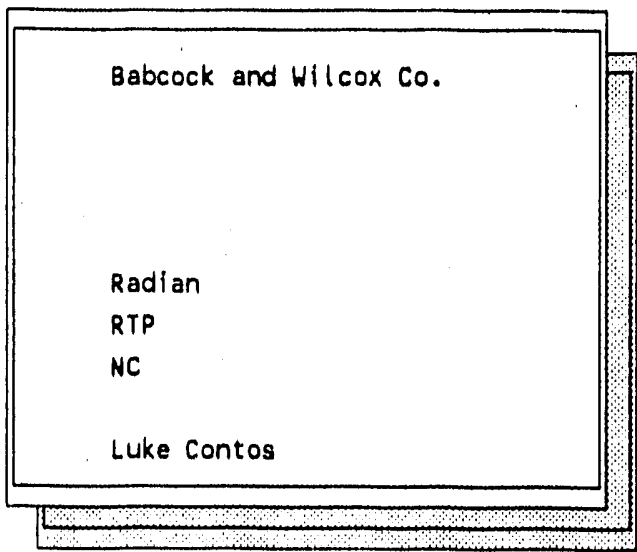

Customer Work Identification LIMB PROJECT

Purchase Order Number 209-026-05-00

\section{Contents:}

Analytical Data Summary

Sample History

Comments Summary

Notes and Definitions

Radian Analytical Services

8501 Mo-Pac Boulevard

P. O. Box 201088

Austin, TX 78720-1088

$512 / 454-4797$

Client Services Coordinator: KAYOUNG

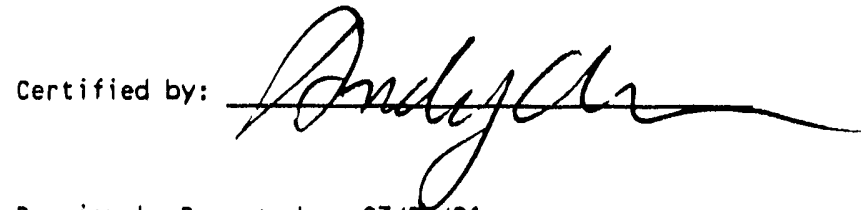

Previously Reported on 03/25/91. 
RADIAN

Analytical Data Summary

Page: 2

Babcock and Wilcox Co.

Radian Work Order: 91.03.009

Sample Identifications

Method/Analyte

LIMB - EMPASH- 10

01

Matrix

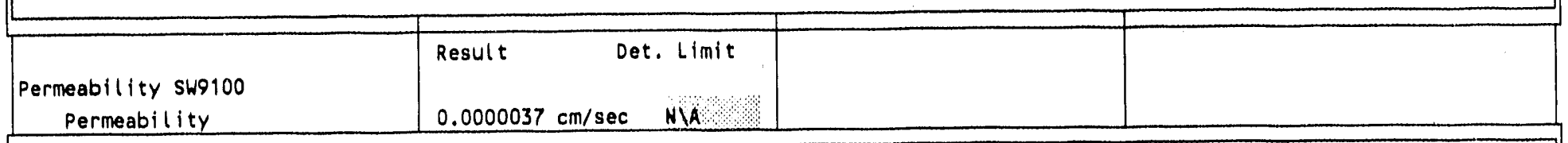

(1) For a detailed description of flags and technical terms in this report refer to the glossary.

$\mathrm{G}-7$ 
Babcock and Wilcox Co.

Radian Work Order: 91.03-009

Sample Identifications and Dates

Sample tD LIMB-EMPASH-10

Date Sampled $\quad 02 / 28 / 91$

Date Received 03/01/91

Matrix

01

Permeability SW9100

Prepared

Analyzed

$03 / 15 / 91$

Analyst

$03 / 19 / 91$

File 10

Blank 10

QST

Instrument

Report as

received

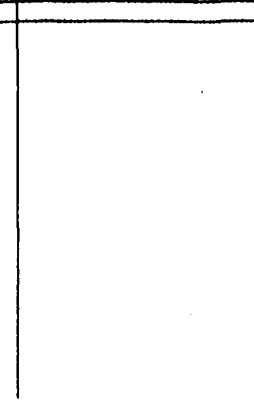

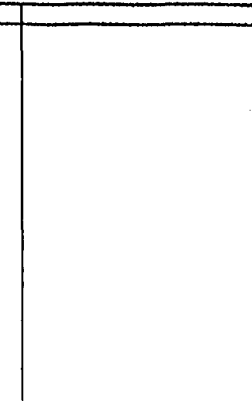

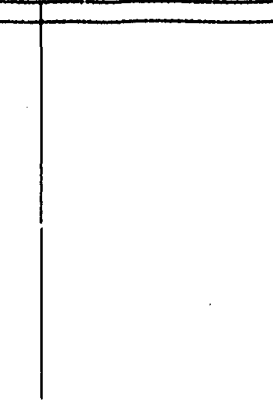

- 


\section{RADIANA}

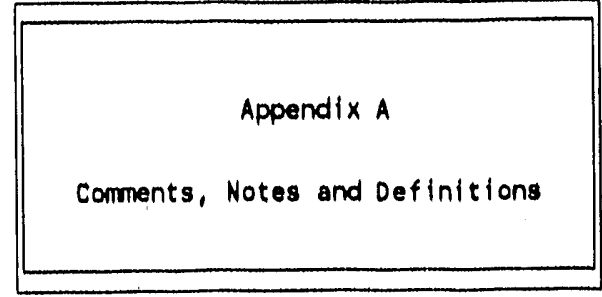

$\bullet$

○

○

○

○

G-9 
Babcock and Wilcox co.

Radian Work Order: 91.03 .009

TERMS USED IN THIS REPORT:

Analyte - A chemical for which a sample is to be analyzed. The analysis will meet EPA method and QC specifications.

Compound - See Analyte.

Detection Limit - The method specified detection limit, which is the lower limit of quantitation specified by EPA for a method. Radian staff regularly assess their labolatories' method detection limits to verify that they meet or are lower than those specified by EPA. Detection limits which are higher than method limits are based on experimental values at the $99 x$ confidence level. The detection limits for EPA CL.P (Contract Laboratory Program) methods are CRaLs (contract required quantitation (imits) for organics and CRDLs (contract required detection (imits) for inorganics. Note, the detection limit may vary from that specified by EPA based on sample size, dllution or cleanup. (Refer to factor, below)

EPA Method - The EPA specified method used to perform an analysis. EPA has specified standard methods for analys is of environmental samples. Radian will perform its analyses and accompanying OC tests in conformance with EPA methods unless otherwise specifled.

Factor - Default method detection limits are based on analys is of clean water samples. A factor is required to calculate sample specific detection limits based on alternate matrices (soil or water), reporting units, use of cleanup procedures, or dilution of extracts/ digestates. For example, extraction or digestion of 10 grams of soll in contrast to 1 liter of water will result in a factor of 100.

Matrix - The sample material. Generally, it will be soil, water, air, oll, or solid wasţe.

Radian Work Order - The unique Radian identification code assigned to the samples reported in the analytical sumary.

Units - ug/L micrograms per liter (parts per billion); liquids/water

$u g / k g$ micrograms per kilogram (parts per. billion); soils/solids

ug/M3 micrograms per cubic meter; air samples

$\mathrm{mg} / \mathrm{L} \quad$ milligrams per liter (parts per million);liquids/water

$\mathrm{mg} / \mathrm{kg} \quad$ milligrams per kilogram (parts per million); soils/solids

* percent; usually used for percent recovery of QC standards

us/cm conductance unit; microsiemans/centimeter

$\mathrm{mL} / \mathrm{hr}$ milliliters per hour; rate of settlement of matter in water

NTU turbidity unit; nephelometric turbidity unit

CU color unit; equal to $1 \mathrm{mg} / \mathrm{L}$ of chloroplatinate salt 
Alr dispersion modeling will be used to assese the relative change In aximum ground lavel pollutant concentratlona for Unlt 4 . The maximum predleted ground level concentration wlll be deternined from the baseline operating conditlons for Unlt 4 during normal flring conditions with no sorbent infoction (flring coll with a 1,8 sulfur content) and for each of the coal/sorbent scenarios that will be evaluated in the Coolside and LIMB Extension studies. The pollutant anlesions evaluated will include $\mathrm{SO}_{2}, \mathrm{NO}_{\mathrm{x}}$ $P M / M_{10}$, and $C O$. The averaging perlods that w1ll be predloted for each pollutant will corraspond with those for whlch a National Aublent Alr Qual1ty Standard (NAAQS) has been established.

In most cases, roductions in predioted maximum ground lovel pollutant concentrations are expected to occur since Unit 4 andselons lovels w11l decrease compared to baseline lovels. If Increases in maximun concentrations over the baseline case are prodlcted, a further evaluation will be conducted to determine if the NMQS will be exceeded. No additional amblent als monteoring will be conducted during tho-denonstation study.

The following anthodology will be used in this atudy:

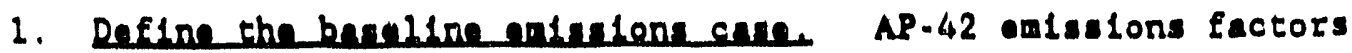
w111 be used to detarmine anissions of $\mathrm{SO}_{2}, \mathrm{NO}_{2}, \mathrm{CO}$, and $\mathrm{PM}^{\mathrm{PM}} 10$ from Unit 4 flring 1.88 sulfur coal if stack data are not avallable. Representative stack parameters (stack axit tomerature and flowrate) for the aaximun firing rate of Unit 4 will be derived from existing stack tost data for the perlod when Undt 4 was flring 1.8 sulfur coal.

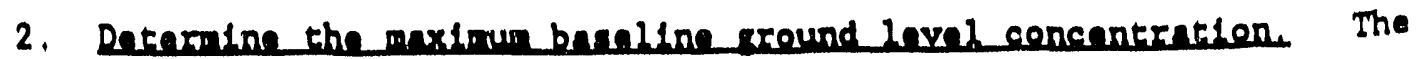
maximua pradicted annual avarage and short torm average off-property concentrations fron Unlt 4 w11l be determined for the baseline enissions case. The aodaling analysis will be conducted using five years of anteorological kan/00s $H-1$ 
date and an EPA approved ale dispersion model ISCST Version 88348. Addltional discussion of the model mothodolsy is presented below.

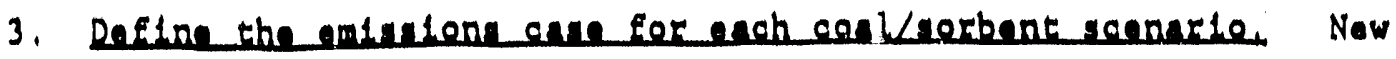
stack parameter and emlssions data for Unit 4 will be doveloped from the actual data collocted from CMM monttoring and frow Mathod 5 testing during the demonetration project.

\section{Detemine the max imum rround level cencentration for a new}

scenarter The maximum predloted annual average and short torm average off property concentrations from Unit 4 w11l be deterained for each coal/sorbent oniselons case. The modeling athodology and aodel lnputs used to determine the aximun concentratlons w111 be ldentical to those used in (2) and discussed below.

5. Compere the mextmum eoncentratione predicted in (2) and (4) The results of the modeling analyses conducted in (2) and (4) will be compared to deteralne the increase (or decrease) in the predicted maximun ground level concentration fne each pollutant and averaging perlod. In some cases, tho maxinum predlcted concentration for the baseline and coal/sorbent case will occur at different receptors for the samo pollutant and averaging porlod because of the differences in stack exit touperature or flowrate. For these cases, the maximun predicted concentration for the baseline case and the coal/sorbent cases w11l be determined at the anximun recoptor location deterained for each case, and the aximum difference reported.

If the difforence In aximum predicted concentration frod the new coal/sorbent case coupared to the beseline case that was dotermined in (5) for all pollutants and averaging perlode result in concentration decrases, no further evaluation will be necessary. Othorwlse, the following analysis will be performed:

6. The monttude of the incrence for ench pollutenge and averestos

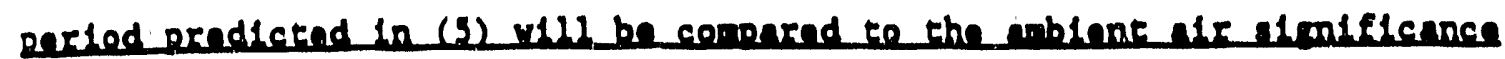

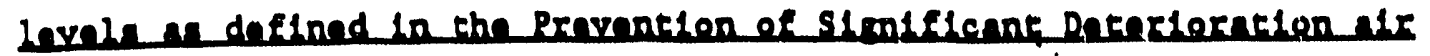
realletion $(40 \mathrm{CRR} 51.165 \mathrm{~b}(2))$. For the pollutants ovaluated in this study, kna/00s 
these valuas are $1 \mathrm{Mg} / \mathrm{m}^{3}\left(\mathrm{SO}_{2}, \mathrm{PM} / \mathrm{PM}_{10}, \mathrm{NO} \mathrm{x}\right)$ for the annual average, $5 \mathrm{\mu g} / \mathrm{m}^{3}$ $\left(\mathrm{SO}_{2}, \mathrm{PH} / \mathrm{FM}_{10}\right)$ for the 24 -hour average, $25 \mathrm{\mu g} / \mathrm{a}^{3}\left(\mathrm{SO}_{2}\right)$ for the 3-hour average, $500 \mathrm{\mu g} / \mathrm{a}^{3}(C O)$ for the 1.hour average, and $2000 \mathrm{\mu g} / \mathrm{a}^{3}(C O)$ for the 8-hour averaging perlod. By definition, if the concentration 1. less than the agnifleance level, a source la not considered to cause or contribute to a violation of the national alr quallty standard. If the lncrease in concontration predicted in (5) for a given pollutant and avaraging period is signifleant, the exlating amblent alr monltoring will be revlewed and the need for colloction of additional monitoring data will be ovaluated.

\section{1 .1 Model Seluction}

The estiantes of abblent alr quality concentrations will be based on the applicable alr quallty model and techniques as specifled in the ERA Guldeline on Alr Quality Models. The EPA epproved version of the Industrial Source Couplax model (ISCST varsion 88348) w111 be used in the modeling analye1s.

\section{1 .2 Keteorolostend Data}

Five years (1981-1985) of aeteorological data will be used in the analys 1s. The surface data were recorded at Hopkins International Alrport in Cleveland, Oh10, and the upper-alr data were recorded at Buffalo International Alrport in Buffalo, Now York. These data were obtalned fron Ohlo Edison in preprocessed formet.

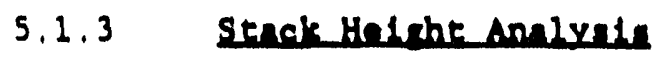

A Good Englnoering Practice (GEP) stack helght amalysis will be conducted. The puxpose of the GEP stack helght analysis is to evaluate the potent1al Influence of bullding wake effecty frod the existing structures on ground lovel concentrations. Bullding dinensions will be input to the ISCST nodel. The worst-case bullding dimension Inpute will be calculated using guidance in the Induatrial Source Couplex (ISC) Uaer's Guide and the Bowran Environantal Engineering GEP computer prograw. 


\subsubsection{Becepter Gerld}

A regularly spaced cartesian grid, with a spacing of 250 to 500 moters, surrounding the facllity w1ll be developed. Addlelonal receptors will be located along the plant fienceline.

\section{2}

\section{Euture Amblent Ale Ound ty Work}

A plant visit was conducted on January 23, 1990. During this visit, Ohlo Edison personnel provided the following lteas:

- Plot plan showing property and fenceline positions

- Bullding orlentation and dimensions

9

- Stack dimonsions

In addition to the above Information, photographs were taken during a tour of the faclilty, and a survey of the local area provided needed information for future modeling work. 

APPENDIX K-1. CLEVELAND-HOPKINS AIRPORT HOURLY SURFACE OBSERVATIONS $(11 / 27 / 90-12 / 05 / 90)$ ID MONTH DAY HOUR CEILING DIR. SPEED BULB COVER CLOUD COVER $\left.\begin{array}{llll}(100 \mathrm{~S} & \mathrm{FT}\end{array}\right)(10 \mathrm{~S}$ DEG.) (KTS) (F) (TENTHS) (TENTHS)

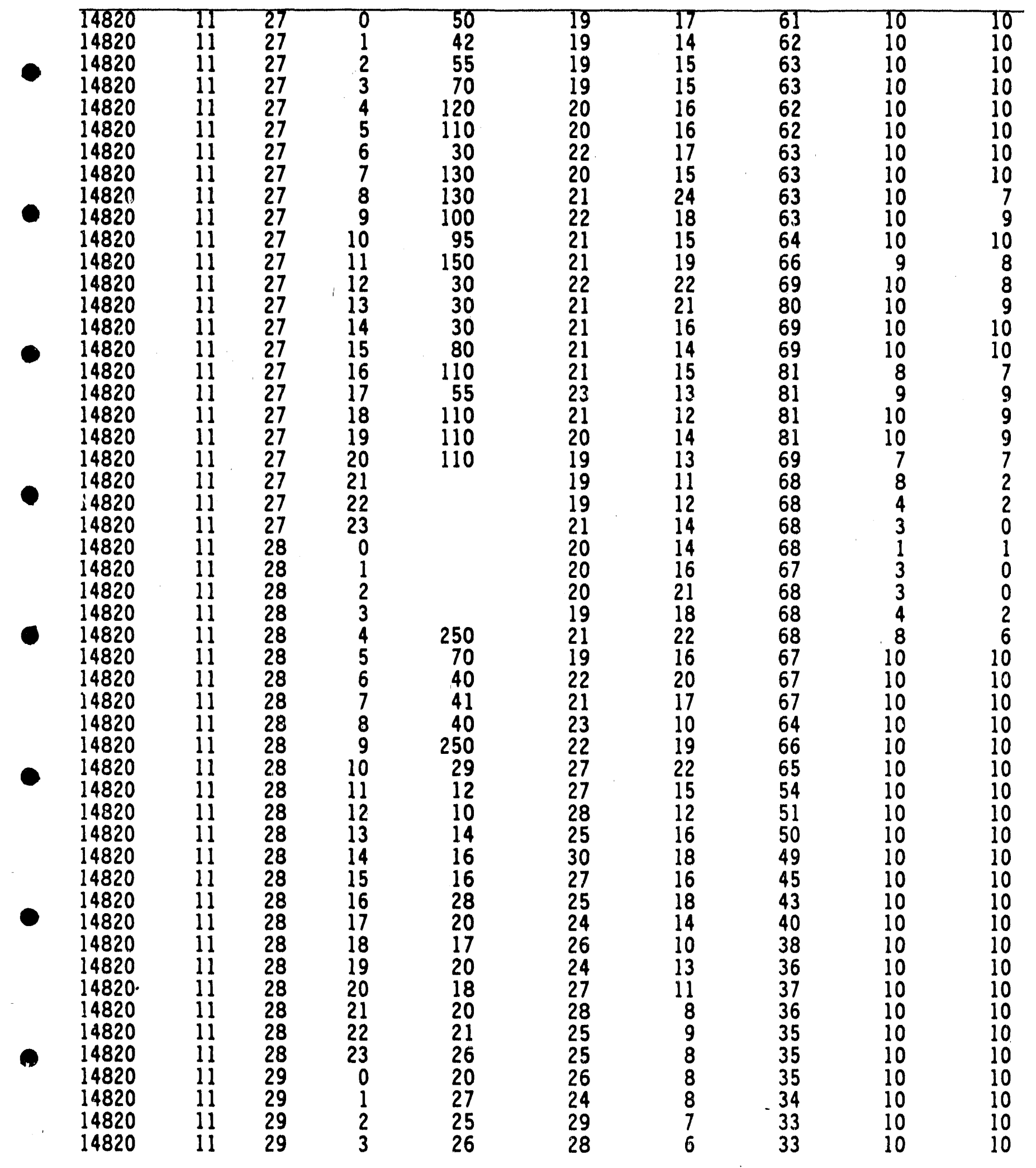


APPENDIX K-1. CLEVELAND-HOPKINS AIRPORT HOURLY SURFACE OBSERVATIONS

$(11 / 27 / 90-12 / 05 / 90)$

STATION WIND WIND DRY CLOUD OPAQUE ID MONTH DAY HOUR CEILING DIR. SPEED BULB COVER CLOUD COVER (100S FT) (10S DEG.) (KTS) (F) (TENTHS) (TENTHS)

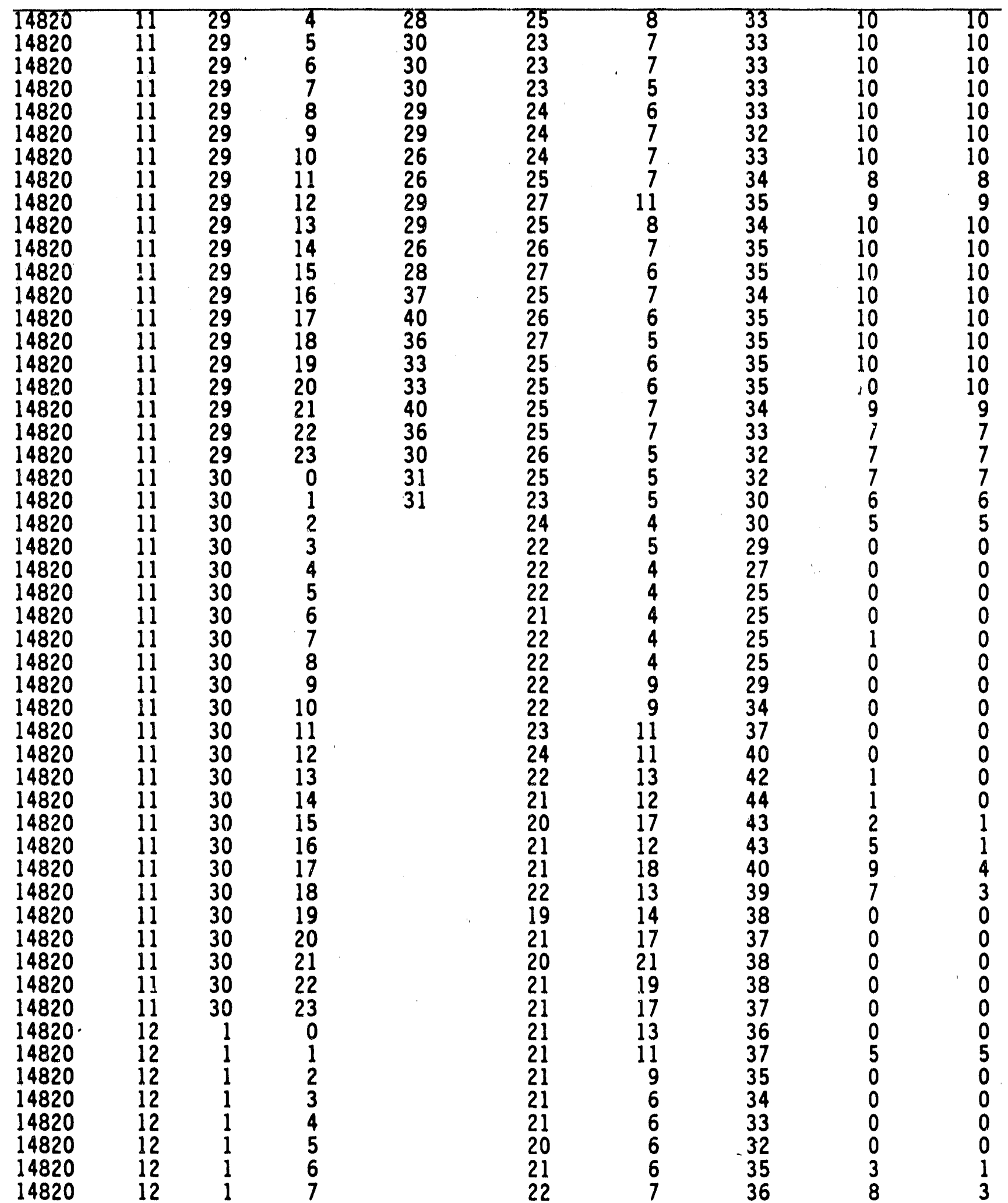


APPENDIX K-1. CLEVELAND-HOPKINS AIRPORT HOURLY SURFACE OBSERVATIONS

$$
(11 / 27 / 90-12 / 05 / 90)
$$

STATION WIND WIND DRY CLOUD OPAQUE ID MONTH DAY HOUR CEILING DIR. SPEED BULB COVER CLOUD COVER (100s FT)(10s DEG.) (KTS)

(F) (TENTHS) (TENTHS)

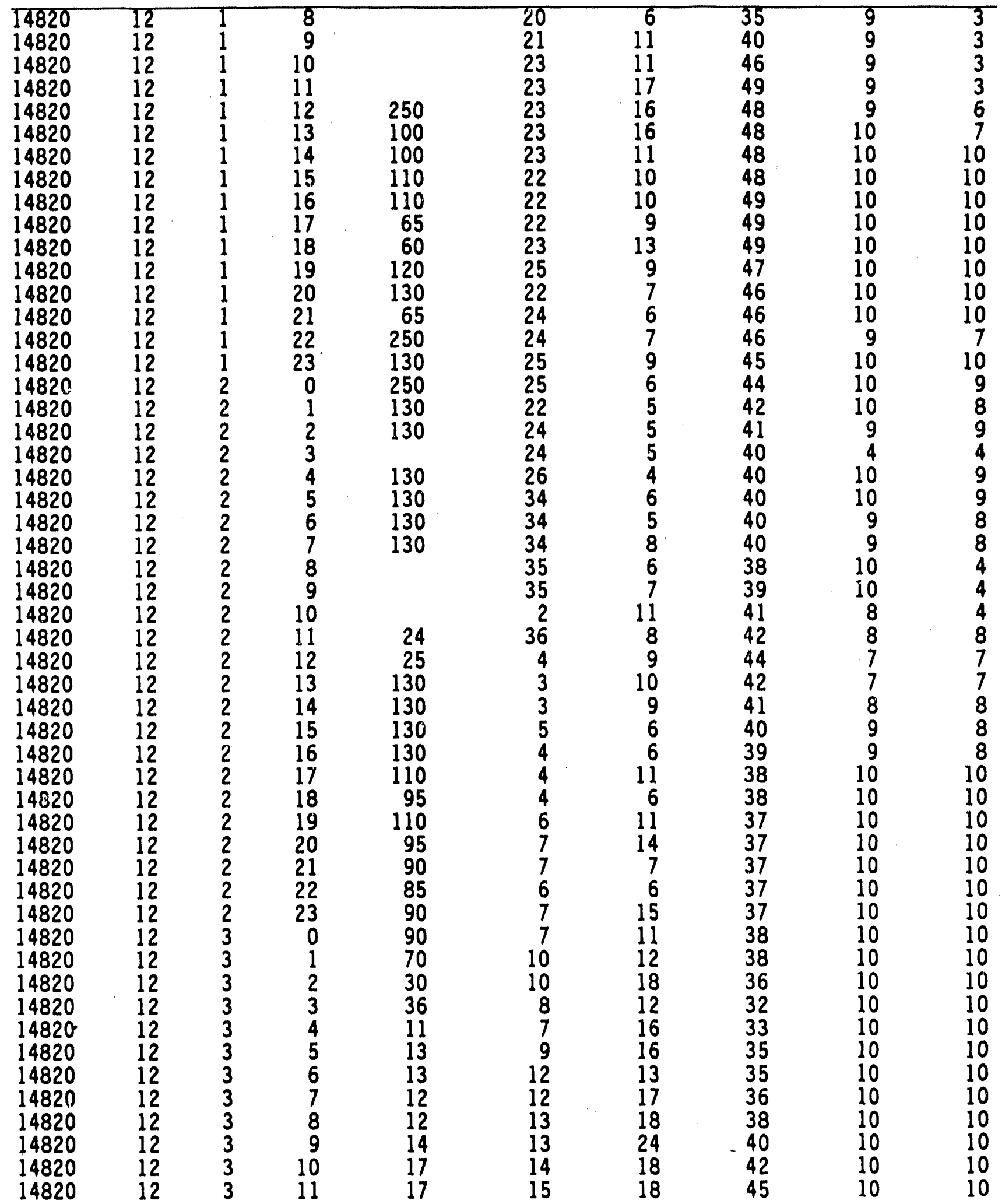


APPENDIX K-1. CLEVELAND-HOPKINS AIRPORT HOURLY SURFACE OBSERVATIONS

$(11 / 27 / 90-12 / 05 / 90)$

STATION WIND WIND DRY ' CLOUD OPAQUE ID MONTH DAY HOUR CEILING DIR. SPEED BULB COVER CLOUD COVER (100S FT)(10S DEG.) (KTS) (F) (TENTHS) (TENTHS)

\begin{tabular}{|c|c|c|c|c|c|c|c|c|}
\hline $\begin{array}{l}14820 \\
14820 \\
14820 \\
14820 \\
14820 \\
14820 \\
14820 \\
14820 \\
14820 \\
14820 \\
14820 \\
14820 \\
14820 \\
14820 \\
14820 \\
14820 \\
14820 \\
14820 \\
14820 \\
14820 \\
14820 \\
14820 \\
14820 \\
14820 \\
14820 \\
14820 \\
14820 \\
14820 \\
14820 \\
14820 \\
14820 \\
14820 \\
14820 \\
14820 \\
14820 \\
14820 \\
14820 \\
14820 \\
14820 \\
14820 \\
14820 \\
14820 \\
14820 \\
14820 \\
14820 \\
14820 \\
14820 \\
14820 \\
14820 \\
14820 \\
14820 \\
14820\end{array}$ & 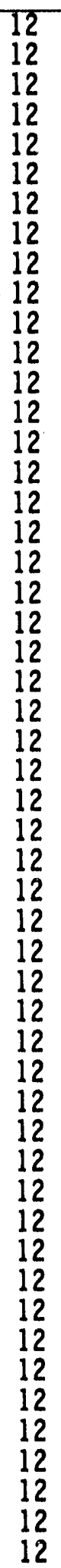 & $\begin{array}{l}3 \\
3 \\
3 \\
3 \\
3 \\
3 \\
3 \\
3 \\
3 \\
3 \\
3 \\
3 \\
4 \\
4 \\
4 \\
4 \\
4 \\
4 \\
4 \\
4 \\
4 \\
4 \\
4 \\
4 \\
4 \\
4 \\
4 \\
4 \\
4 \\
4 \\
4 \\
4 \\
4 \\
4 \\
4 \\
4 \\
5 \\
5 \\
5 \\
5 \\
5 \\
5 \\
5 \\
5 \\
5 \\
5 \\
5 \\
5 \\
5 \\
5 \\
5 \\
5\end{array}$ & 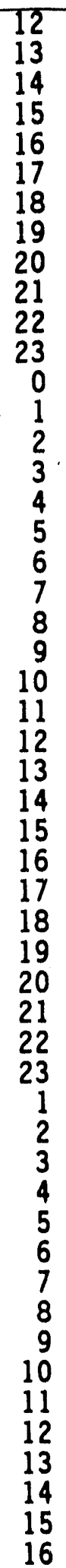 & $\begin{array}{l}15 \\
13 \\
14 \\
15 \\
26 \\
28 \\
16 \\
26 \\
26 \\
70 \\
28 \\
33 \\
32 \\
31 \\
34 \\
32 \\
31 \\
24 \\
26 \\
26 \\
23 \\
26 \\
20 \\
20 \\
20 \\
20 \\
16 \\
13 \\
55 \\
80 \\
12 \\
14 \\
29 \\
28 \\
26 \\
29 \\
29 \\
29 \\
26 \\
26 \\
29 \\
29 \\
29 \\
28 \\
29 \\
28 \\
26 \\
33 \\
32 \\
26\end{array}$ & $\begin{array}{l}17 \\
17 \\
18 \\
19 \\
18 \\
19 \\
29 \\
24 \\
31 \\
29 \\
29 \\
24 \\
24 \\
25 \\
24 \\
25 \\
23 \\
23 \\
23 \\
23 \\
23 \\
24 \\
24 \\
25 \\
25 \\
25 \\
24 \\
26 \\
25 \\
25 \\
27 \\
28 \\
30 \\
31 \\
29 \\
31 \\
31 \\
32 \\
30 \\
30 \\
31 \\
30 \\
30 \\
33 \\
31 \\
29 \\
25 \\
24 \\
26 \\
24 \\
25 \\
23\end{array}$ & 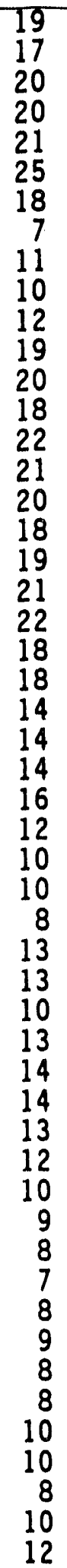 & $\begin{array}{l}47 \\
49 \\
51 \\
54 \\
57 \\
56 \\
57 \\
53 \\
50 \\
50 \\
50 \\
50 \\
4\end{array}$ & $\begin{array}{l}10 \\
10 \\
10 \\
10 \\
10 \\
10 \\
10 \\
10 \\
10 \\
10 \\
10 \\
10 \\
10 \\
10 \\
10 \\
10 \\
10 \\
10 \\
10 \\
10 \\
10 \\
10 \\
10 \\
10 \\
10 \\
10 \\
10 \\
10 \\
10\end{array}$ \\
\hline
\end{tabular}


APPENDIX K-1. CLEVELAND-HOPKINS AIRPORT HOURLY SURFACE OBSERVATIONS

$(11 / 27 / 90-12 / 05 / 90)$

\begin{tabular}{|c|c|c|c|c|c|c|c|c|}
\hline $\begin{array}{c}\text { STATION } \\
\text { ID }\end{array}$ & MONTH & DAY & HOUR & $\begin{array}{lc}\text { WIND } \\
\text { CEILING } & \text { DIR. } \\
(100 \mathrm{~S} \text { FT })(10 \mathrm{~S} \text { DEG. })\end{array}$ & $\begin{array}{l}\text { WIND } \\
\text { SPEED } \\
\text { (KTS) }\end{array}$ & $\begin{array}{l}\text { DRY } \\
\text { BULB } \\
(F)\end{array}$ & $\begin{array}{c}\text { CLOUD } \\
\text { COVER } \\
\text { (TENTHS) }\end{array}$ & $\begin{array}{l}\text { TOTAL } \\
\text { OPAQUE } \\
\text { CLOUD COVE } \\
\text { (TENTHS) }\end{array}$ \\
\hline $\begin{array}{l}14820 \\
14820 \\
14820 \\
14820 \\
14820 \\
14820 \\
14820 \\
14820\end{array}$ & $\begin{array}{l}12 \\
12 \\
12 \\
12 \\
12 \\
12 \\
12 \\
12\end{array}$ & $\begin{array}{l}5 \\
5 \\
5 \\
5 \\
5 \\
5 \\
5 \\
6\end{array}$ & $\begin{array}{l}17 \\
18 \\
19 \\
20 \\
21 \\
22 \\
23 \\
0\end{array}$ & $\begin{array}{l}22 \\
22 \\
19 \\
19 \\
21 \\
21 \\
21 \\
21\end{array}$ & $\begin{array}{r}14 \\
9 \\
8 \\
16 \\
14 \\
14 \\
12 \\
13\end{array}$ & $\begin{array}{l}31 \\
31 \\
30 \\
31 \\
31 \\
31 \\
31 \\
32\end{array}$ & $\begin{array}{r}10 \\
9 \\
8 \\
7 \\
7 \\
8 \\
8 \\
8\end{array}$ & $\begin{array}{l}4 \\
1 \\
1 \\
0 \\
2 \\
2 \\
2 \\
2\end{array}$ \\
\hline
\end{tabular}


APPENDIX K-2 . BUFFALO INTERNATIONAL AIRPORT MIXING HEIGHTS

$(11 / 27 / 90-12 / 05 / 90)$

\begin{tabular}{|c|c|c|c|c|}
\hline $\begin{array}{c}\text { STATION } \\
\text { ID }\end{array}$ & MONTH & DAY & $\begin{array}{l}\text { MORNING } \\
\text { MIXING } \\
\text { HEIGHT } \\
\quad(\mathrm{m})\end{array}$ & $\begin{array}{c}\text { AFTERNOON } \\
\text { MIXING } \\
\text { HEIGHT } \\
(\mathrm{m})\end{array}$ \\
\hline $\begin{array}{l}14733 \\
14733 \\
14733 \\
14733 \\
14733 \\
14733 \\
14733 \\
14733 \\
14733\end{array}$ & $\begin{array}{l}11 \\
11 \\
11 \\
11 \\
12 \\
12 \\
12 \\
12 \\
12\end{array}$ & $\begin{array}{l}27 \\
28 \\
29 \\
30 \\
01 \\
02 \\
03 \\
04 \\
05\end{array}$ & $\begin{array}{r}546 \\
272 \\
1860 \\
1208 \\
787 \\
684 \\
927 \\
1305 \\
739\end{array}$ & $\begin{array}{r}1447 \\
1957 \\
1162 \\
1499 \\
1313 \\
313 \\
1110\end{array}$ \\
\hline
\end{tabular}



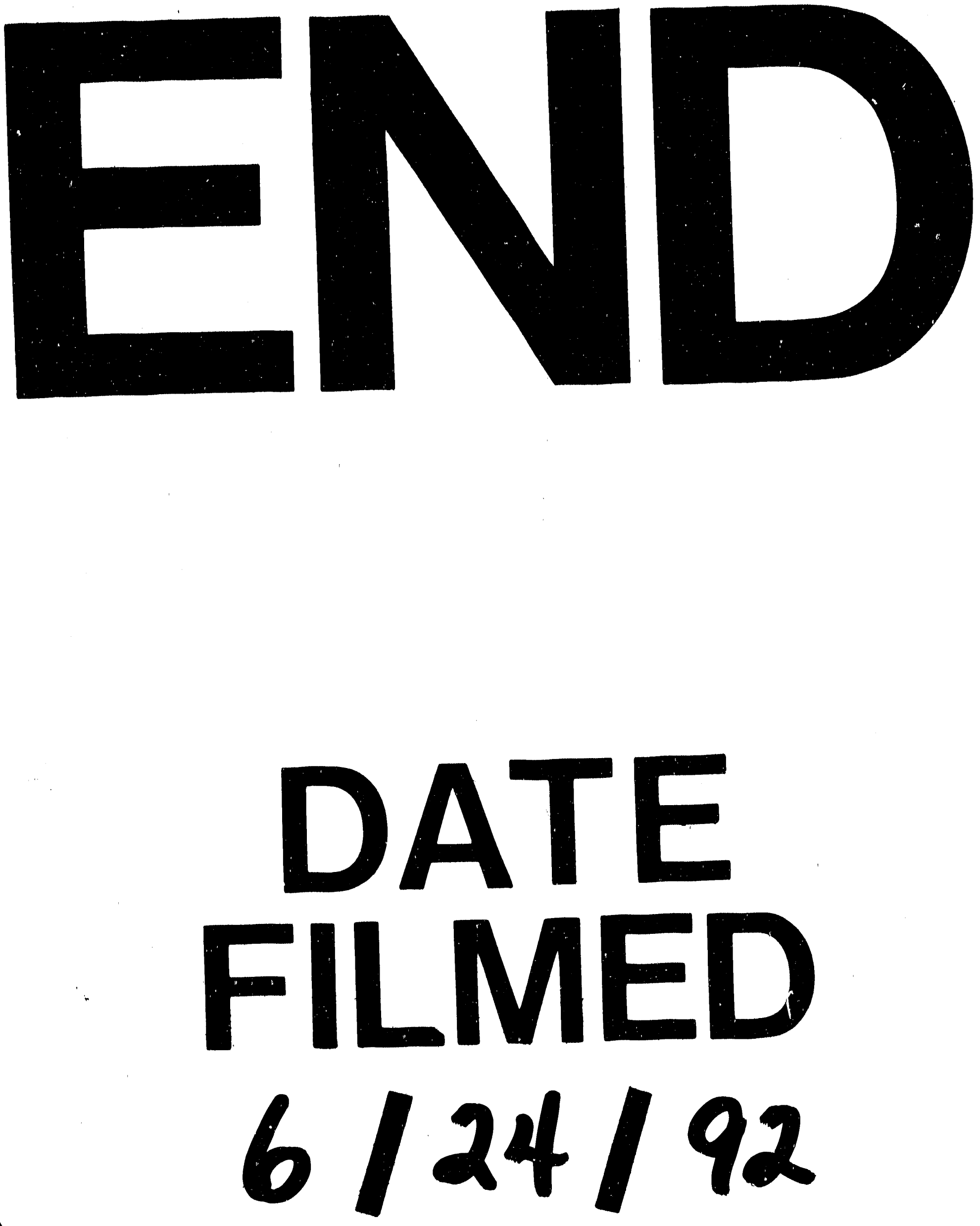

† 
